UNIVERSIDADE DE SÃO PAULO

FACULDADE DE ARQUITETURA E URBANISMO

ELIANE GUEDES

DECISÕES NA ESFERA PÚBLICA RELATIVAS A EMPREENDIMENTOS ESTRUTURAIS DE DESENVOLVIMENTO URBANO:

O caso do sistema metroviário da cidade do Rio de Janeiro 


\section{ELIANE GUEDES}

Decisões na esfera pública relativas a empreendimentos estruturais de desenvolvimento urbano:

o caso do sistema metroviário da cidade do Rio de Janeiro

Tese apresentada a Faculdade de Arquitetura e Urbanismo da Universidade de São Paulo para obtenção do Título de Doutor em Arquitetura e Urbanismo

Área de concentração: Planejamento Urbano e Regional

Orientador: Prof. Dr. Ricardo Toledo Silva 
AUTORIZO A REPRODUÇÃO E DIVULGAÇÃO TOTAL OU PARCIAL DESTE TRABALHO, POR QUALQUER MEIO CONVENCIONAL OU ELETRÔNICO, PARA FINS DE ESTUDO E PESQUISA, DESDE QUE CITADA A FONTE.

E-MAIL: arqelianeguedes@terra.com.br

\begin{tabular}{|l}
\hline Guedes, Eliane \\
Decisões na esfera pública relativas a empreendimentos \\
estruturais de desenvolvimento urbano: o caso do sistema \\
metroviário da cidade do Rio de Janeiro. / Eliane Guedes. - \\
São Paulo, 2009. \\
340 p. : il. \\
Tese (Doutorado - Área de Concentração: Planejamento \\
Urbano e Regional) - FAUUSP. \\
Orientador: Ricardo Toledo Silva \\
1.Planejamento territorial urbano 2.Metrô - Rio de Janeiro \\
(RJ) 3.Empreendimentos imobiliários 4.Decisão \\
administrativa - Aspectos socioeconômicos I.Título \\
CDU 711.4
\end{tabular}


Ao Professor Philip Oliver Mary Gunn, in memoriam, pelo seu amor incondicional ao nosso país. 
Aos meus pais, pelo apoio sempre presente em todos os momentos da minha vida.

À minha filha, pelas horas roubadas.

Ao meu companheiro, pelas certezas e pelo carinho que me dá. Às minhas amigas pelas observações, comentários, reforços: Helena Menna Barreto Silva, Alejandra Devecchi, Mayumi Hirye, Cida Louro, Jackie Low-Beer, Maria Tereza Baines, e aos amigos e amigas não nomeados, mas presentes na minha vida nos últimos vinte anos.

Finalmente, ao meu professor orientador, Ricardo Toledo Silva, pelo apoio intelectual e direcionamento para ultrapassar minhas limitações num tema tão abrangente. 


\section{RESUMO}

O trabalho apresenta uma discussão sobre a tomada de decisão por agentes públicos em relação a empreendimentos estruturais de desenvolvimento urbano no Brasil. Relata as principais teorias desenvolvidas sobre o assunto e, a partir da reconstituição do processo decisório para a implantação do sistema metroviário da cidade do Rio de Janeiro, comprova a hipótese de que o Metrô-RJ não foi concebido como uma solução para um problema de deslocamento, mas como um produto auto-suficiente. Mostra ainda que esse produto não foi significativo para a sociedade como um todo durante todo o período de maturação da idéia e da construção, mas foi principalmente fruto de uma decisão autoritária tomada na instância federal, distante das aspirações e necessidades locais, por agentes de interesse que dominaram o processo de decisão. Secundariamente, comprova que os produtores de materiais de transporte e a burocracia a serviço dos agentes políticos com forte viés autoritário foram forças motoras de grande expressão, e ainda que os agentes imobiliários e a população em geral - tradicionais interessados nos incrementos de acessibilidade - pouco ou nada interferiram no processo de decisão pelo sistema em questão.

Palavras-chave: Processo de decisão, Metrô do Rio de Janeiro, Interesses dos atores sócioeconômicos, Empreendimento estruturais de desenvolvimento urbano. 


\section{ABSTRACT}

The paper presents a discussion on decision-making by public officials concerning structural undertakings of urban development in Brazil. It describes the main theories developed on the subject, and through the reconstitution of the process for implementing the subway system of Rio de Janeiro, it proves the hypothesis that the Metrô-RJ was not designed as a solution to a displacement problem but as a self-sufficient product. It also shows that the product was not important to the society as a whole throughout the period of the maturation of the idea and the construction, but it was mainly the result of an authoritarian decision at the federal level, far from the desires and local needs, performed by interest agents that dominated the decisionmaking process. Secondly, it proves that producers of transport inputs and the governamental bureaucracy in the service of politicians with strong authoritarian bias were driving forces of great expression. Also, real estate agents and the general public - traditional stakeholders seeking for increments of accessibility - little or nothing interfered in the decision towards the implementation of the subway system in the city.

Keywords: Decision-making, Rio de Janeiro Subway System, Social and economic stakeholders concerns, Structural undertakings of urban development. 


\section{LISTA DE ILUSTRAÇÕES}

Ilustração 1 - Principais Subsistemas e Grupos de Interesse presentes no Processo de Decisão relativo ao Sistema Metroviário

Ilustração 2 - Estado do Rio de Janeiro resultante da Fusão do antigo Estado do Rio de Janeiro e do Estado da Guanabara

Ilustração 3 - Estado do Rio de Janeiro e os Municípios da Região Metropolitana do Rio de Janeiro

Ilustração 4 - Administrações na área da Cidade do Rio de Janeiro

Ilustração 5 - Cidade do Rio de Janeiro - Ocupação Urbana e Direção da Expansão no início do século XIX

Ilustração 6 - Cidade do Rio de Janeiro - Direção da Expansão Urbana em meados do século XX

Ilustração 7 - Novas Áreas de Expansão no Centro da Cidade com o desmonte do Morro do Castelo

Ilustração 8 - Cidade do Rio de Janeiro - Principais Eixos Rodoviários e Ferroviários 1960-1970

Ilustração 9 - Cidade do Rio de Janeiro - Vetores de Crescimento no final do Século XX.

Ilustração 10 - Mapa do Sistema de Bondes - 1907 e 1946

Ilustração 11 - Linhas de Trem no início do Século XX

Ilustração 12 - Mapa do Sistema Ferroviário em Operação 2007 - SUPERVIA e CENTRAL

Ilustração 13 - Rede Metroviária 2007 e Expansão da Rede

Ilustração 14 - Principais Estudos sobre o Metrô na Cidade do Rio de Janeiro

Ilustração 15 - Principais Traçados Propostos para o Metrô-RJ

Ilustração 16 - Ocorrências dos Estudos/Propostas de Transporte Metroviário

Ilustração 17 - Traçado do Estudo de Viabilidade 1968

Ilustração 18 - Traçado definido pelo Grupo da Fusão

Ilustração 19 - Traçado do Pré-Metrô 


\section{LISTA DE TABELAS}

Tabela 1 - Evolução Demográfica dos Municípios do Rio de Janeiro e São Paulo 1872 1980

Tabela 2 - Evolução da Renda Interna do Município do Rio de Janeiro 1950-1969

Tabela 3 - Distribuição da Renda na RMRJ - 1975 em Porcentagem Acumulada

Tabela 4 - Evolução da Composição da Renda por Setor Econômico do Município do Rio de Janeiro (MRJ) e do Brasil, 1950 - 1965

Tabela 5 - Mão-de-obra Ocupada em 1980 por Setor de Atividade no Estado do Rio de Janeiro (ERJ), Região Metropolitana do Rio de Janeiro (RMRJ) e Município do Rio de Janeiro (MRJ)

Tabela 6 - População Residente e Mão-de-Obra na Indústria em Alguns Distritos do MRJ, 1980

Tabela 7 - Número de Passageiros Transportados por Modalidade/Ano - Rio de Janeiro 1896 a 1920 e Área Metropolitana 1930 a 1970

Tabela 8 - Número de Passageiros Transportados por Modalidade/Ano - Área Metropolitana* 1980 a 2005

Tabela 9 - Evolução da Situação Acionária da Companhia do Metrô-RJ 1969-1980 através do Capital Integralizado (em Cr\$ constantes 1976) e Participação Acionária Percentual

Tabela 10 - Aplicação dos Recursos da Companhia do Metrô-RJ por Categoria, 1974-1980, em \% do total das Aplicações de Capital

Tabela 11 - Empresas Contratadas para a Construção do Metrô-RJ 1970 a 1979

Tabela 12 - Valores do Terreno Padrão em Bairros Selecionados do Rio de Janeiro nas imediações da Rede Prioritária do Metrô-RJ 1973 e 1980 


\section{LISTA DE GRÁFICOS}

Gráfico 1 - Evolução dos Sistemas de Transportes no Rio de Janeiro - Períodos Críticos

Gráfico 2 - Empréstimos Externos 1969-1980, não vinculados a Fornecimento de Material

Gráfico 3 - Créditos Externos vinculado ao Fornecimento de Material, 1969-1980

Gráfico 4 - Crédito Externo vinculado ao Fornecimento de Material, por Nacionalidade, 19691980

Gráfico 5 - Empréstimos Internos não vinculados, 1969-1980

Gráfico 6 - Crédito Interno não vinculado a Compra de Equipamento Nacional, 1969-1980

Gráfico 7 - Evolução dos Recursos Captados no Mercado Financeiro Externo e Interno, 1969-1980

Gráfico 8 - Evolução do Número de Contratos Assinados pela Companhia do Metrô-RJ 1967-1979 


\section{LISTA DE ENTREVISTAS}

\section{Agentes Públicos}

Carlos Nelson dos Santos - Pesquisador do Centro de Pesquisas Urbanas do IBAM Instituto Brasileiro de Administração Municipal - entrevista em 09/03/82. Sociólogo, observador independente dos assuntos urbanos da região.

Carlos Jorge - Engenheiro da Cia. Do Metrô-RJ - entrevista em 12/03/82.

Jorge Guilherme Francisconi -Presidente da EBTU - Empresa Brasileira dos Transportes Urbanos - entrevista em 23/07/81 e 24/07/81. Arquiteto e administrador público, responsável pela política nacional de transportes urbanos, aí incluídos os Metrôs do Rio de Janeiro e São Paulo à época do Governo da Fusão.

Jorge Schnoor - BNH - Banco Nacional da Habitação - entrevista em 17/02/82. Engenheiro ferroviário, trabalhou nos diferentes governos do Estado do Rio de Janeiro, apresentando propostas para o desenvolvimento ferroviário do estado e da região da cidade do Rio de Janeiro.

Josef Barat - Secretario dos Transportes do Estado do Rio de Janeiro 1975 a 1978 entrevista em 25/03/81, 03/04/81, 06/04/81 e 08/04/81. Economista, foi testemunha dos fatos relativos à fusão dos Estados do Rio de Janeiro e da Guanabara e, como Secretário Estadual dos Transportes, foi responsável pela formulação e implantação da política de transportes do novo governo.

Kleber Paulistano de Sant'anna - Assessor de Comunicação da Secretaria dos Transportes do Estado do Rio de Janeiro - entrevista em 25/01/82. Presente durante o primeiro governo da Fusão.

Rafael de Almeida Magalhães - vice-governador na administração Carlos Lacerda entrevista em 12/03/82. Testemunha das articulações para o novo desenho institucional da região.

\section{Dirigentes da Cia do Metrô do Rio de Janeiro}

Bruno Costa Soares - Diretor Financeiro e Administrativo da Cia do Metrô - entrevista em 18/02/82.

Cláudio Senna Frederico - Diretor de Operações da Cia do Metrô - entrevista em 07/12/81.

Leandro Petronilho - Diretor de Engenharia da Cia do Metrô - entrevista em 08/12/81.

Noel de Almeida - Presidente da Cia do Metrô no período 1975 - 1980 - entrevista em 28/01/82. 
Representantes de Entidades de Classe

Aury Sampaio - Representante do Clube dos Engenheiros no Conselho Consultivo da Cia do Metrô-RJ (1.972 a 1.978) - entrevista em 15/02/82. Engenheiro, ativo participante no posicionamento da corporação dos engenheiros face às opções tecnológicas para o enfrentamento das questões relativas aos transportes urbanos na cidade do Rio de Janeiro.

José Flávio Mendonça Monteiro Pessoa - Representante do IAB - Instituto dos Arquitetos do Brasil - Rio de Janeiro - entrevista em 05/03/82.

Plínio Catanhede - Presidente dos Clube dos Engenheiros - entrevista em 25/01/82. Engenheiro, articulador da posição da corporação dos engenheiros face às questões relativas aos transportes urbanos na cidade do Rio de Janeiro.

\section{Eleitos e Representantes da Sociedade Organizada e da Imprensa}

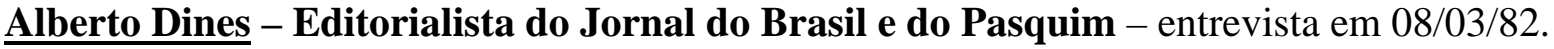

Francisco Viana - Editorialista de O Globo - entrevista em 25/02/82.

Jó Resende - Presidente da FAMERJ - Federação das Associações de Moradores do Estado do Rio de Janeiro - entrevista em 04/03/82.

Mauro Magalhães - Deputado Estadual - entrevista em 10/03/82. Deputado de oposição ao Governo Negrão de Lima.

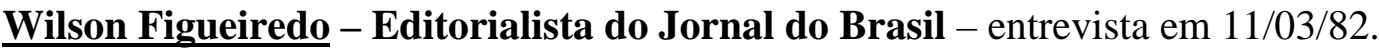

\section{Representantes do Setor Secundário}

Mario Leão Ludolf - Representante da FIRJAN - Federação das Indústrias do Estado do Rio de Janeiro no Conselho Consultivo da Cia do Metrô-RJ - entrevista em 15/02/82. Conhecedor do posicionamento das indústrias cariocas e fluminenses nos diversos segmentos da produção industrial.

\section{Representantes do Setor Terciário}

Décio Burlamaqui - Membro do Conselho Diretor da ACRJ - Associação Comercial do Estado do Rio de Janeiro - entrevista em 19/01/81. Representante da ACRJ no Conselho consultivo da Cia do Metrô por nove anos.

Silvio Cunha - Presidente do Clube de Diretores de Lojistas do Rio de Janeiro entrevista em 26/01/82.

Representantes de Entidade Produtora de Estudos e Projetos - SOFRETU

Arras - Presidente da SOFRETU - Societé Française d'Études des Transports Urbains entrevista em 21/05/81. Responsavel por toda a atuação da SOFRETU, sediado em Paris. 
Patruck e Barby - SOFRETU - RJ, Societé Française d'Études des Transports Urbains - entrevista em 21/05/81. Responsáveis pela filial Rio de Janeiro da empresa de estudos e projetos com atuação mundial.

Young - SOFRETU - RJ, Societé Française d'Études des Transports Urbains entrevista em 02/07/81. Responsavel pela filial Rio de Janeiro da empresa de estudos e projetos com atuação mundial, no período 1.973 a 1.976.

Representantes dos Produtores de Material Ferroviário

Fábio Kovarick - Diretor Executivo da ABIFER - Associação Brasileira da Indústria Ferroviária - entrevista em 03/02/82.

José Carlos Couto Viana - Presidente da MAFERSA/SP - entrevista em 01/02/82.

Mario Melo Torres - Diretor da Divisão de Equipamentos da COBRASMA - entrevista em 03/02/82.

Representantes do Mercado Imobiliário

José Conde Caldas - Rrepresentante da ADEMI - Associação dos Dirigentes de Empresas do Mercado Imobiliário - entrevista em 03/03/82.

Mauro Magalhães - Rrepresentante da ADEMI - Associação dos Dirigentes de Empresas do Mercado Imobiliário - entrevista em 10/03/82.

\section{Representantes da Construção Civil}

Francismar Barbieri - Associação dos Empreiteiros do Estado do Rio de Janeiro entrevista em 08/03/82.

Paes Leme - Assessor de Diretoria da Mendes Junior Ltda - Representante do SINICON - Sindicato Nacional da Indústria da Construção - entrevista em 11/02/81.

Waldner Paschoal - Diretor da ESUSA e Diretor do Consórcio ECISA-ECEC de 1970 a 1982 - entrevista em 15/02/82. 


\section{SUMÁRIO}

INTRODUÇÃO

CAPÍTULO 1 - TEORIAS DE PLANEJAMENTO E AS DECISÕES NA ESFERA PÚBLICA

1.1 A discussão da racionalidade

1.2 Novos rumos da teoria e da prática a partir dos anos 1980

1.3 Contexto político-institucional brasileiro para as decisões relativas a empreendimentos estruturais de desenvolvimento urbano

CAPÍTULO 2 - TIPOLOGIA DE ATORES PRESENTES NO PROCESSO DECISÓRIO

2.1 O Modelo Explicativo

2.2 Identificação dos principais grupos de interesse e seus possíveis comportamentos

CAPÍTULO 3 - A CIDADE DO RIO DE JANEIRO

3.1. Evolução político-administrativa

3.2. População e economia

3.3. Evolução da ocupação urbana

CAPÍTULO 4 - COMO SE DESLOCA A POPULAÇÃO METROPOLITANA

4.1 Bondes

4.2 Trens

4.3 Ônibus e Microônibus (vans, kombis e outros)

4.4 Barcas

4.5 Metrô

163

4.6 O conjunto dos sistemas de transportes

4.7 Planos e projetos de transportes urbanos elaborados

CAPÍTULO 5 - DA IDÉIA À REALIZAÇÃO DO METRÔ-RJ

5.1 As principais propostas

5.2 Iniciativas de Caráter Institucional 201

5.3 Estudo de Viabilidade do Consórcio CCN - Hochtief - Deconsult 211

CAPÍTULO 6 - TRAÇADO, RECURSOS FINANCEIROS E CONSTRUÇÃO 218

6.1 A Evolução do Traçado 218

6.2 A Evolução da Alocação de Recursos Financeiros 236

6.3 A Construção 252

CAPÍTULO 7 - OS PRINCIPAIS AGENTES DA DECISÃO 266

7.1 Os Produtores dos Transportes Urbanos 268

$\begin{array}{ll}7.2 \text { Os Consumidores dos Transportes Urbanos } & 285\end{array}$

7.3 Os Gestores dos Transportes Urbanos 306

CAPÍTULO 8 - A REDE DA DECISÃO - CONCLUSÕES 315

REFERÊNCIAS BIBLIOGRÁFICAS 329 
INTRODUÇÃO 
Aos 16 anos matei meu professor de lógica [...] (cartesiana)

Campos de Carvalho

\section{Como, quando e porque da implantação do Metrô-RJ}

Se as decisões em matérias de interesse público fossem tomadas a partir de avaliações baseadas em parâmetros de racionalidade técnica, a explicação do processo de decisão para a implantação do sistema metroviário da cidade do Rio de Janeiro - Metrô-RJ - seria clara e até óbvia. Se assim fosse, estaríamos à frente de um problema cuja solução foi concebida e implementada pelos legítimos representantes da comunidade. Com base no modelo racional de decisão, instrumental de análise bastante utilizado na literatura técnica, quando se constataram as deficiências nos deslocamentos urbanos no Rio de Janeiro (problema), foi implantado um sistema de transporte - Metrô (읻ãa), concebido como a resposta mais adequada no momento considerado. Na pesquisa da melhor solução, várias alternativas técnicas, incluindo seus impactos, teriam sido analisadas por profissionais competentes e com instrumental técnico adequado. Ponderadas as vantagens e desvantagens de cada uma das alternativas, de acordo com os objetivos explicitados pela comunidade, a escolha teria sido feita pelo agente de decisão de maior legitimidade na resolução dos problemas da população.

No Rio de Janeiro, o processo de decisão e implantação do Metrô não foi nem claro, nem simples e muito menos lógico, permitindo-se observar a ausência das condições ideais que permitam a compreensão do processo decisório baseado no modelo racional de decisão.

Ao contrário, numa trajetória bastante irregular, o processo de decisão de se implantar o Metrô-RJ demorou 40 anos para se consubstanciar numa decisão definitiva. Nesse período de tempo, as condições de deslocamento se alteraram significativamente sem que as soluções 
consideradas tenham se modificado no sentido de acompanhar os rumos do problema. É o caso do traçado, por exemplo, que se manteve o mesmo, embora o eixo principal dos deslocamentos urbanos tenha se alterado. As iniciativas e os apoios para a realização do empreendimento também foram mudando ao longo do tempo: foi de interesse da iniciativa privada no início do período, passando à iniciativa pública nos 20 anos que antecederam a decisão final. Hoje, o sistema metroviário foi parcialmente privatizado, voltando à situação institucional da proposta inicial, há mais de 70 anos atrás.

A opção por um sistema de transporte rápido de massa do tipo Metrô não surgiu da apreciação de várias alternativas para a resolução de um problema. Na maioria das discussões que puderam ser recuperadas através da imprensa, publicações especializadas e entrevistas, não foram discutidos os problemas dos deslocamentos e como eles poderiam ser resolvidos, mas discutiu-se o Metrô em si, enquanto obra pública e opção tecnológica.

Não houve mobilização popular a favor nem contra a implantação do sistema, e o trecho construído e em operação não serve à área mais carregada no que se refere ao número de passageiros/hora.

Mesmo decorridos 40 anos - 1928 a 1968 - entre a primeira proposta consistente e a decisão formal para a implantação do sistema, sua aprovação não engendrou, de imediato, a sua construção. Mais tempo e mais negociações foram necessárias para que, em 1979, apenas 4 km estivessem em operação ${ }^{1}$, completando assim mais de meio século de maturação.

Quais foram então os determinantes do processo de decisão e implantação do Metrô-RJ que não resistem a uma análise baseada em parâmetros de racionalidade técnica? 
As hipóteses centrais que, respondendo tentativamente a essa questão, geraram este trabalho de investigação foram assim construídas:

1. O Metrô-RJ não foi concebido como uma solução para um problema de deslocamento, mas como um produto, isolado dos demais modos de transporte.

2. Esse produto não foi significativo para a sociedade como um todo durante todo o período de maturação do empreendimento. A idéia só foi aceita e implementada quando um ou mais agentes de interesse dominaram o processo de decisão pela implantação do empreendimento e conseguiram encaminhar sua aprovação formal e sua construção.

A formulação das hipóteses secundárias, a partir das hipóteses centrais, indicou alguns possíveis interessados que, teoricamente, poderiam ser os grupos mais favorecidos pela construção de sistemas metroviários, a serem investigados prioritariamente:

- os agentes imobiliários;

- $\quad$ os produtores de materiais de transporte;

- a população em geral e

- a burocracia técnica do governo.

Para que as hipóteses secundárias pudessem ser comprovadas utilizou-se, como modelo de análise, a técnica de compartimentação da sociedade urbana do Rio de Janeiro em diferentes grupos de agentes sociais e econômicos, possíveis atores do processo de decisão, e, em seguida, procedeu-se à análise de seus interesses e comportamentos, acreditando-se que a decisão final foi o resultado de uma determinada conjunção de forças.

\footnotetext{
${ }^{1}$ Estão hoje em operação 35,6 km, sendo 13,9 km em solução convencional - subterrânea - e 21,7 km em
} 
Através da explicitação das relações entre os grupos sociais presentes nesse processo, num determinado momento histórico e lugar de produção, através de seus atores, ativos e passivos, procura-se compreender a lógica das decisões com relação à construção de um espaço - um empreendimento estrutural de desenvolvimento urbano -, neste caso o sistema metroviário da cidade do Rio de Janeiro, aqui entendido em três etapas principais: idéia, decisão e implantação.

A pesquisa bibliográfica percorreu textos referenciais sobre teorias de decisão e sobre estudos de caso relativos a decisões em transportes urbanos em várias cidades do mundo. A pesquisa de campo foi feita no início dos anos 1980, imediatamente após a consumação do processo decisório - idéia e realização -, através de entrevistas com os representantes dos principais grupos de atores identificados, consultas diretas à Companhia do Metrô-RJ e revisão da imprensa (geral e especializada) e foi complementada nos últimos três anos. Esta visou reconstituir o processo de decisão do Metrô-RJ, construindo um entendimento da cidade do Rio de Janeiro, dos deslocamentos urbanos, de questões-chave da decisão - os diferentes traçados, a construção, o financiamento - e da trajetória institucional percorrida. Os resultados a que se chegou são muito diferentes, e muitas vezes contraditórios, daqueles contemplados pela literatura corrente e é aí que repousa o interesse deste trabalho.

As decisões públicas ocorrem num ambiente essencialmente político, no qual a dimensão social é vasta e especialmente complexa. O caminho a percorrer entre a idéia, a decisão e a construção de um espaço nos parece sinuoso, ideologicamente contraditório, ocorrendo em vários contextos e esferas de poder e com uma grande complexidade de atores, 
transformando-se muitas vezes numa arena de confrontações e negociações, perdas e ganhos, que atinge uma vasta gama de grupos sociais. Os atores mais influentes não são necessariamente os que encabeçam o processo de decisão e muitas vezes são de difícil identificação. Os argumentos econômicos ou técnicos assumem, na maior parte das vezes, características de instrumental político, de forma a imprimir seriedade a um processo nem sempre legítimo.

Dentro deste vasto quadro de inserção, pretende-se com este trabalho identificar os principais condicionantes nas decisões para a produção dos transportes urbanos no Brasil, num momento específico da história deste país, auxiliado pela análise de uma intervenção específica na cidade do Rio de Janeiro, com a construção de seu sistema de transporte metroviário, o Metrô-RJ. Pesquisas sobre a natureza das decisões, além de seu objetivo explicativo acima apontado, permitem também contribuir para que esse tipo de decisão possa ser mais transparente, possibilitando o estabelecimento de futuras ações normativas no sistema de decisões, tornando-o mais democrático e conhecido de uma parcela maior da população.

No âmbito dos transportes urbanos em países da periferia do sistema capitalista ou países emergentes os recursos financeiros são geralmente escassos e a produção no setor dos transportes representa uma parte significativa da produção econômica local. No entanto, alguns grupos sociais permanecem fortemente desfavorecidos, de forma que as decisões tomadas em nome da sociedade têm geralmente um custo social muito elevado e quase sempre mal repartido. 
Essas decisões têm ainda uma repercussão concreta no desenho da cidade - produção do espaço - aonde os custos para modificações ou mesmo reorientações destas ações são muito elevados, cristalizando por muitas décadas um modo de vida e de produção.

Cabe acrescentar que o período mais crítico para a tomada de decisão formal com relação ao Metrô-RJ ocorreu num momento político especial que o país atravessava, em plena ditadura militar, de grande crescimento econômico e grande capacidade de investimento da poupança pública - fase conhecida como "milagre brasileiro”. Foi a época da montagem das grandes estatais, algumas das quais viriam a sofrer importantes transformações no final do século XX e neste início de século. Várias companhias públicas foram criadas, respaldadas no Decreto-Lei 200, dentre elas a Companhia do Metrô do Rio de Janeiro e a Companhia do Metrô de São Paulo.

Este estudo retrata um período de tomada de decisões políticas para implantação de obras públicas, lastreadas em um modelo de desenvolvimento econômico, cujos reflexos, positivos e negativos, perduram até hoje. Os resultados deste modelo vêm sendo questionados e alterados significativamente a partir da redemocratização nacional nos anos 1980. Nos dias de hoje, mesmo com uma incipiente participação da população nas decisões relativas a grandes empreendimentos públicos, todos os processos decisórios têm crescido em transparência, gerando debates sobre aspectos que, à época da implantação do Metrô-RJ, não foram minimamente abordados, como por exemplo os aspectos ambientais e os aspectos relativos à contratação de empresas para a construção das obras civis e fornecimento de material. Hoje, o país possui um quadro legal que concorre para essa transparência, especialmente para o processo de contratação de fornecedores que certamente passam a exercer uma influência de menor grandeza na tomada de decisão, bem como com a lei de responsabilidade fiscal, que imprime mais seriedade nas decisões dos agentes públicos. 
Assim, este trabalho não tem o intuito de esclarecer e contribuir com o entendimento das práticas de decisão contemporâneas, mas estabelecer um registro histórico e crítico de um período que se encerra nos anos 1980, com o processo de redemocratização do país, resgatando o conhecimento das práticas desenvolvidas durante o período de cunho autoritário de tomada de decisões. Como veremos, embora muito se tenha discutido sobre o tema, a prática da formulação de planos “de cima para baixo”, em nome da racionalidade técnica, persiste até hoje em vários domínios do conhecimento e em várias situações políticoinstitucionais e em vários países.

Este trabalho está organizado em 8 capítulos sendo que o Capítulo 1 - Teorias de planejamento e as decisões na esfera pública - a análise das decisões em grandes intervenções urbanas apresenta uma descrição e análise das principais escolas de pensamento com relação às decisões na esfera pública, em especial quanto a empreendimentos estruturais de desenvolvimento urbano. São especialmente analisadas as questões relativas à racionalidade, freqüentemente discutidas nas décadas de 1950 a 1970 nos Estados Unidos e na França e seus rebatimentos no pensamento nacional, enfatizando-se a situação no período abordado por este trabalho de pesquisa - décadas de 1960 e 1970. Indica os rumos contemporâneos da teoria e da prática do planejamento e da decisão: a ampliação do conceito de legitimidade, a compartimentação da prática do planejamento e a sofisticação das formas de lidar com a informação.

\section{O Capítulo 2 - Tipologia de atores presentes no processo decisório - modelo explicativo}

traz uma discussão sobre um modelo explicativo utilizado na literatura dos anos 1980 para a compreensão dos processos decisórios, adaptado para a situação do estudo de caso em questão, construindo assim uma tipologia de atores e possíveis hipóteses de comportamento 
face à situação considerada. A partir de uma discussão teórica, baseada em bibliografia internacional com predominância de textos contemporâneos à decisão estudada, foram apontados conceitos básicos, que orientaram estudos da lógica das decisões em transportes urbanos em várias cidades do mundo, e que orientam a formulação de hipóteses para este trabalho específico.

O Capítulo 3 - A cidade do Rio de Janeiro - aspectos político-administrativos, economia, população e evolução da ocupação urbana apresenta a cidade do Rio de Janeiro nos seus aspectos político-administrativos, economia, população e evolução da ocupação urbana, com o objetivo de contextualizar o estudo de caso deste trabalho, especialmente no período analisado, de 1960 a 1980.

O Capítulo 4 - Como se desloca a população metropolitana apresenta a evolução dos deslocamentos na cidade de maneira geral e para cada modo de transporte, ressaltando os momentos mais críticos, de forma que possa ser discutida a adequação da decisão de se implantar um sistema metroviário na cidade. É dada ênfase especial nos períodos de maturação da idéia, da decisão formal e da implantação do trecho inicial, considerando a integração entre os modos. São também descritos os principais planos e projetos de transportes urbanos, salientando a presença ou não de um sistema metroviário em cada um deles e sua importância relativa.

O Capítulo 5 - Da idéia à realização do Metrô do Rio de Janeiro marchas e contra marchas de caráter institucional aponta os principais estudos elaborados ao longo do tempo para a implantação de um sistema metroviário na cidade, considerando traçados, tecnologias e as instituições e ou indivíduos que os propuseram, chegando ao Estudo de Viabilidade que foi 
o elemento formal da decisão de se implantar o sistema. As iniciativas de caráter institucional são apresentadas de forma cronológica, construindo um quadro referencial que permite o entendimento dos momentos propícios à decisão.

\section{O Capítulo 6 - A evolução do traçado, do financiamento e da construção descreve} detalhadamente os diferentes traçados propostos, procurando ressaltar o caminho para a decisão com relação à localização efetivamente aprovada e implantada. Da mesma forma, foram levantados os recursos financeiros de fato alocados no sistema, desde sua concepção até a finalização das obras do trecho inicial, distinguindo recursos próprios das diversas esferas do poder executivo, bem como empréstimos e recursos ligados ao fornecimento de materiais e equipamentos. A construção do trecho inicial do sistema também foi reconstituída, de forma a distinguir possíveis interesses dos diversos setores da construção civil e da produção de materiais e equipamentos na decisão pelo sistema implantado.

O Capítulo 7 - Os principais agentes da decisão apresenta o comportamento de cada grupo de atores que poderia ter interesse na implantação do sistema, ao confrontar os fatos que efetivamente ocorreram, levantados através da pesquisa de campo, com as hipóteses de comportamento estabelecidas no capítulo 2, concebidas a partir da literatura consultada, para os produtores, consumidores e gestores da implantação do Metrô-RJ.

O Capítulo 8 - Conclusões finaliza este estudo apresentando as hipóteses centrais e secundárias que puderam ser comprovadas através dos dados empíricos e aquelas que foram refutadas. Em resumo, o trabalho comprova a hipótese de que o Metrô-RJ não foi concebido como uma solução para um problema de deslocamento, mas como um produto auto-suficiente em si mesmo, bem como a hipótese de que esse produto não foi significativo para a sociedade 
como um todo durante todo o período de maturação. Foi sim, uma decisão autoritária tomada na instância federal, distante das aspirações e necessidades locais, por agentes de interesse que dominaram o processo de decisão. Secundariamente, comprova-se que os produtores de materiais de transporte e a burocracia a serviço dos agentes políticos com forte viés autoritário foram forças motoras de grande expressão e ainda que os agentes imobiliários e a população em geral - tradicionais interessados nos incrementos de acessibilidade - pouco ou nada interferiram no processo de decisão pelo sistema em questão. 
CAPÍTULO 01 


\section{TEORIAS DE PLANEJAMENTO E AS DECISÕES NA ESFERA PÚBLICA}

\section{A análise das decisões em empreendimentos estruturais de desenvolvimento urbano}

Este capítulo inicial apresenta uma descrição e análise das principais linhas de pensamento com relação às decisões na esfera pública, em especial quanto a empreendimentos estruturais de desenvolvimento urbano, sendo especialmente analisadas as questões relativas à racionalidade, muito discutidas nas décadas de 1950 a 1970, bem como aqueles autores que se contrapunham fortemente a essa linha de raciocínio nos Estados Unidos e na França. Essa discussão deu origem aos principais conceitos das teorias da organização para, em seguida, direcionar-se para outros caminhos que indicam um aumento na complexidade da dicotomia dos processos de decisão racionais-lineares x aleatórios-sinuosos. Trata em seguida dos rumos contemporâneos da teoria e da prática do planejamento e da decisão, assim organizados: a ampliação do conceito de legitimidade, incluindo uma discussão sobre o planejamento feito a partir da demanda em contraposição à oferta; a compartimentação da prática do planejamento em áreas do conhecimento cada vez mais especializadas e a sofisticação das formas de lidar com a informação, com a inclusão de recursos técnicos que possibilitam cada vez mais a inclusão de uma grande variedade de aspectos de suporte à tomada de decisão.

Tem por objetivo apresentar um quadro do pensamento sobre a questão das decisões relativas a empreendimentos estruturantes, para nele situar o processo de decisão para a construção do sistema metroviário da cidade do Rio de Janeiro e analisar suas características. Para tanto, é também discutido neste capítulo o contexto político-institucional brasileiro para as decisões relativas a grandes investimentos públicos, de forma a auxiliar na compreensão de como as decisões eram efetivamente tomadas, bem como seus principais agentes, no período abordado por este trabalho. 


\subsection{A discussão da racionalidade}

Na esfera da administração pública, quando grandes investimentos públicos estão em pauta, pode-se afirmar que existe uma complexa relação entre aqueles que planejam e aqueles que efetivamente decidem. As características dessa relação, se mais ou menos estreita, gerando atuações mais ou menos entrelaçadas, têm sido motivo de análises e discussões teóricas que se iniciaram na metade do século XX, em várias partes do mundo, quase sempre acompanhadas de exemplos concretos e em vários domínios do conhecimento.

Num extremo dessa abordagem teórica, acreditou-se que o planejamento feito a partir de uma conceituação técnica adequada, acompanhada de métodos sofisticados de coleta e tratamento de informações e análises baseadas em passos racionais de encaminhamento, chegando-se a projetos e programas específicos, proporciona pouco espaço para o componente político no momento da tomada de decisão, ficando o planejador numa situação de grande importância - de grande valorização técnica. Quando o planejador e aquele que efetivamente decide se confundem no mesmo indivíduo, atinge-se a melhor situação possível para a prática eficiente do planejamento.

No extremo oposto, pode-se constatar, a partir de observação empírica que, na grande maioria das vezes, decisões são tomadas aleatoriamente e que pequenos projetos vão sendo implantados, sem que estejam amparados por uma visão de conjunto - numa visão de planejamento - que indique os grandes rumos a serem tomados. Nestes casos, o papel do planejador se enfraquece, sendo praticamente ignorado pelo político-administrador, numa situação de grande distanciamento entre os dois atores. 
Parte da literatura tenta demonstrar que não existem as duas situações extremas acima apresentadas, mas que a realidade ocorre em posições intermediárias entre as mesmas, tendo seus atores principais - o planejador e o agente da decisão - importâncias relativas variáveis em cada caso analisado.

Mais recentemente, nos últimos 30 anos, novos rumos do processo decisório em vários países passam a considerar outros agentes de decisão, diretamente afinados com os usuários do resultado da decisão, levando então a situações que efetivamente também não se encaixam nem no extremo da racionalidade do planejador e nem no outro extremo das decisões por projetos isolados (respondendo aos interesses dos grupos mais influentes), numa evolução ou aperfeiçoamento do processo decisório numa direção mais participativa, tendo como principal interessado o usuário final.

As análises mais tradicionais de processos decisórios relativos a grandes investimentos públicos se utilizam do Modelo Racional da Decisão que discute essencialmente o agente formal da decisão, os objetivos que nortearam o projeto, o leque de alternativas considerado e a solução escolhida. Em estudos mais completos, acrescenta-se uma avaliação das condições anteriores e posteriores à intervenção, procurando-se apreender dessa leitura elementos que permitam uma melhor compreensão dos aspectos técnicos do processo idéia-decisão-implantação. Fica reproduzido na análise, o modelo teórico da atividade de planejamento como processo racional, do qual resulta a solução a ser implantada, nos moldes do Planejamento Global ou Integrado ${ }^{1}$, amplamente discutido nas décadas de 1960 e 1970, quando se acreditou que um exaustivo conhecimento da realidade seria condição essencial para o sucesso das soluções. Com o desenvolvimento de métodos de coleta de dados e de tratamento e representação da informação,

\footnotetext{
${ }^{1}$ Na literatura de língua inglesa, tratado como Comprehensive Planning.
} 
com a expansão das técnicas computacionais, acreditava-se na possibilidade de conferir à atividade de planejamento um caráter de indiscutível competência na proposição de soluções e na indicação daquela mais adequada aos objetivos explicitados, com a orientação implícita de reduzir o componente político das decisões.

Destaca-se nesse extremo conceitual da atividade do planejador e do agente da decisão, os trabalhos desenvolvidos por Melville Branch $^{2}$ que, a partir da década de 1950, trata detalhadamente das vantagens da prática do Planejamento Global ou Integrado nas questões urbanas e regionais. O autor responde às críticas mais severas sobre o modelo, ao identificar os "sete pecados mortais dos Master Plans”3, e propor melhorias para cada aspecto frágil ressaltado. Chega a propor a sofisticação desse modelo incorporando aos planos e projetos, técnicas de gerenciamento municipal que possibilitariam a instalação do processo de planejamento continuado, que ele cunha de Planejamento Global ou Integrado Contínuo, o estágio mais sofisticado desse planejamento abrangente. Através do acompanhamento de várias experiências em cidades nos Estados Unidos, o autor é grande defensor do técnicoplanejador como o principal agente do interesse público nas oportunidades de intervenção e mudança. $^{4}$

\footnotetext{
${ }^{2}$ BRANCH, M. C. Comprehensive City Planning - General Theory and Practice. LosAngeles: Palisades Publishers, 1983. 203 páginas e Id. Continuous City Planning - Integrating Municipal Management and City Planning. New York: John Wiley and Sons, 1981. 181 p. Destacam-se na extensa bibliografia em língua inglesa relativa ao Planejamento Racional, Global ou Integrado.

${ }^{3}$ Id., Continuous City Planning - Integrating Municipal Management and City Planning. New York: John Wiley and Sons, 1981. p. 47. Nossa tradução.

${ }^{4}$ Cabe observar que, embora esse debate de idéias tenha ocorrido mais freqüentemente no período que vai de 1950 a 1970, através de artigos em periódicos especializados, Branch publica vários livros na década de 1980 na defesa do Planejamento Global ou Integrado, muito utilizados nas agências de planejamento local nos Estados Unidos, o que demonstra a aceitação de suas idéias entre aqueles que efetivamente trabalham com planejamento. Cabe observar que M. C. Branch foi o primeiro PhD em Planejamento Urbano nos Estados Unidos.
} 
No final da década de 1950, alguns autores começam a rejeitar a idéia de um caminho racional, cartesiano e exaustivo na geração de soluções, no qual a lógica dos meios resultaria fatalmente no fim desejado, muitos em função de uma atitude de desilusão com relação às práticas do planejamento racional. Mesmo Branch ${ }^{5}$ afirma que em muitas cidades americanas na década de 1970, os planejadores urbanos municipais estimavam que a chance de sucesso dos organismos de planejamento municipal em influenciar o crescimento e desenvolvimento municipal nas direções estabelecidas por seus Planos Diretores seria de 5 a 10\%.

Ainda nos Estados Unidos, Lindblom ${ }^{6}$, num artigo que se tornaria clássico, The Science of Muddling Through, primeiramente publicado em 1959, apresenta um posicionamento totalmente contrário ao anterior - da racionalidade eficiente - ao afirmar que as decisões em matéria de investimentos públicos são um produto do toma lá, dá cá ${ }^{7}$ e consentimento mútuo entre os inúmeros participantes do processo decisório e pouco se reportam às determinações do planejamento abrangente. Para ele, as decisões são feitas através de um método de limitadas comparações sucessivas, afirmando que quando as decisões são feitas em função das vantagens entre duas ou mais alternativas, estas são sempre muito próximas entre si. Ressalta também que as decisões não têm a pretensão de responder aos ideais de toda a sociedade. Lindblom define essa prática como um novo método de planejamento e decisão, embora muitos autores considerem esse novo método como o não método.

\footnotetext{
${ }^{5}$ BRANCH, M. C. Continuous City Planning - Integrating Municipal Management and City Planning, New York: John Wiley and Sons, 1981. p. 80.

${ }^{6}$ LINDBLOM, C. E. The Science of Muddling Through. In FALUDI, A. (Org.) A Reader in Planning Theory. New York: Pergamon Press. Primeiramente publicado na Public Administration Review, Spring 1959. Nossa tradução.

${ }^{7}$ Na literatura de língua inglesa, tratado como "give and take”.
} 
Lindblom confronta todos os passos metodológicos do planejamento abrangente às práticas que, ele acredita, refletem o comportamento mais próximo da realidade, e conclui que esse comportamento é exatamente oposto àquele preconizado pelo modelo racional-abrangente. Pode-se citar a questão relativa ao estabelecimento de objetivos e valores sociais para uma determinada ação de planejamento, que, no modelo racional-abrangente deve ser um prérequisito para a análise de uma determinada alternativa. Nas situações práticas analisadas pelo autor, o agente da decisão não se posiciona entre alternativas que reflitam objetivos diversos; ao contrário, seu domínio de ação está restrito aos objetivos que não especifiquem valores contraditórios entre os grupos sociais concernentes. Decisões entre alternativas que respondam a objetivos e valores muito distintos ou até mesmo conflituosos não são tomadas e nem sequer explicitadas. Sobre a questão da abrangência da análise, que deve ser a maior possível no planejamento abrangente, Lindblom argumenta que na realidade, ao se planejar e decidir, efeitos importantes são desconsiderados, muitas alternativas potenciais também não são apresentadas e que valores de muitos grupos sociais são desprezados ${ }^{8}$.

A partir das posições opostas defendidas por Branch e Lindblom, segue-se um rico debate conceitual entre autores americanos, dentre os quais merecem destaque Etzioni ${ }^{9}$, Rabinovitz ${ }^{10}$, Allison $^{11}$ e Andersen ${ }^{12}$, que apresentam posições intermediárias, rejeitando tanto o posicionamento da linearidade-racionalidade do modelo abrangente do planejamento e

\footnotetext{
${ }^{8}$ Lindblom discorre sobre a inadequação da maior parte dos passos da prática do planejamento abrangente. Alguns conceitos de interesse foram aqui traduzidos livremente.

${ }^{9}$ ETZIONI, A. Mixed-scanning: a Third Approach to Decision Making. In: FALUDI, A. A Reader in Planning Theory”. New York: Pergamon Press, 1973. Primeiramente in: Public Administration Review, dez. 1967.

${ }^{10}$ RABINOVITZ, F. Politics, Personality and Planning. In: FALUDI, A. (Org.) A Reader in Planning Theory. New York: Pergamon Press, 1973. Primeiramente publicado na Public Administration Review, mar. 1967.

${ }^{11}$ ALLISON, G. Essence of Decision: Explaining the Cuban Missile Crisis. Boston, [s.n.], 1971. 329 p.

${ }^{12}$ ANDERSEN, J. E. Public Policy-Making. New York: Holt, Reinhart and Winston, 1977. 178 p.
} 
conseqüente decisão, quanto à total aleatoriedade e incrementalismo dos seus maiores críticos. Abandonam esses conceitos extremos e restritos aos planejadores e orientam seus pensamentos na direção da multiracionalidade dos atores presentes nas organizações e nas agências governamentais.

Etzioni observa que a prática do incrementalismo tem a grande vantagem de conseguir avanços significativos, quase sempre através de pequenos projetos ou políticas públicas que se diferenciam muito pouco das já existentes. Na realidade, o autor acredita que decisões fundamentais, mais gerais - estas sim, representando os anseios de toda a sociedade -, orientam as decisões incrementais, mesmo que pequenas decisões possam paulatinamente transformar pensamentos mais gerais e fundamentais. Chega a propor uma terceira via para a prática do planejamento e da decisão, que ele chama de "mixed-scanning approach", incluindo tanto elementos de natureza geral de planejamento quanto de decisões imediatistas, que se constituem no dia-a-dia das organizações. Esse conceito abre as portas para as idéias de planejamento de médio prazo, construindo uma ponte entre os dois conceitos ${ }^{13}$.

Na década de 1960, Rabinovitz, trabalhando nas questões de definição do papel que o especialista em planejamento urbano deve desempenhar enquanto profissional, introduz claramente o dilema entre desempenhar uma função estritamente técnica, não interferindo nos ideais a serem buscados e nem nos processos políticos de implementação, ou desempenhar um papel político, de forma que suas idéias possam se efetivar. Baseia-se no conceito de que existe uma variedade de oportunidades de decisão na sociedade, respondendo a interesses mais ou menos definidos e mais ou menos consentidos, e que, desta forma, existe uma diversidade de

\footnotetext{
${ }^{13}$ Além dos autores acima citados, pode-se acrescentar como parte desse grupo, autores que se posicionam com conceitos intermediários entre o planejamento racional-abrangente e o incremental, dentre eles: MEYERSON, M. Building the Middle-Range Bridge for Comprehensive Planning. e ROBINSON, I. Beyond the Middle-range Planning Bridge. Ambos in: FALUDI, A. (Org.) A Reader in Planning Theory. New York: Pergamon Press, 1973.
} 
papéis para aqueles que almejem guiar o desenvolvimento urbano. Indica que, embora a maioria dos profissionais prefira uma atuação técnica, muitos já delineiam uma atuação praticamente coincidente com o agente da decisão, com características predominantemente políticas. Revela o conceito nascente de que o planejador deve trabalhar na mediação dos interesses entre grupos presentes na sociedade, interessados num determinado projeto ou política pública, embora muitas vezes se posicione na defesa do seu próprio interesse ou de um grupo específico com o qual se identifica - multiracionalidade dos atores.

Em outras áreas do conhecimento, pode-se observar um caminho semelhante ao descrito acima, na problematização e teorização sobre a tomada de decisão, sendo de especial interesse os estudos desenvolvidos na área das relações internacionais por Graham Allison. No seu livro clássico Essence of Decision - Explaining the Cuban Missile Crisis, o autor descreve e analisa a decisão sobre o posicionamento de mísseis soviéticos em território cubano, a resposta americana com o bloqueio naval e o conseqüente recuo da URSS e retirada do aparato nuclear, ocorrido em 1962, através dos três modelos explicativos a seguir:

- o modelo do ator racional, semelhante ao chamado modelo racional-abrangente apresentado nos textos de teoria do planejamento, no qual o caminho trilhado pelo agente da decisão - sempre único e legítimo - é o caminho da melhor solução após a avaliação de todas a alternativas possíveis sob a luz de objetivos perfeitamente identificáveis;

- o modelo oriundo da teoria das organizações, onde as decisões são tomadas de forma incremental, dentro da lógica das organizações, desenvolvida por March e Simon ${ }^{14}$, que guarda muita semelhança com o modelo de Etzioni - o planejamento e as decisões refletem uma multiplicidade de atores agindo sob a orientação de um conjunto de rotinas pré-estabelecidas, decidindo sempre em função de um conjunto de alternativas

\footnotetext{
${ }^{14}$ Allison discorre detalhadamente sobre a teoria das organizações desenvolvida por SIMON, H. A. e MARCH, J. G. em seu livro fundamental Organizations, 1958, e no MARCH, J. G. (Org.) Handbook of Organizations. Chicago, 1965.
} 
que pouco diferem entre si e cujos objetivos gerais se mesclam com os objetivos específicos das organizações participantes e

- o modelo político-governamental, que, na sua essência, trata de decisões tomadas por atores que agregam comportamentos individuais, conforme seus próprios interesses e de grupos específicos, internos e externos às organizações, mesmo respondendo pelas organizações onde atuam.

Allison conclui que o terceiro modelo, baseado nas lógicas dos grupos de interesse e também dos interesses individuais, é o que tem as melhores condições de responder às indagações feitas sobre as intenções soviéticas, sobre a formulação da resposta americana e sobre a sábia decisão soviética de retirar o aparato nuclear. Através da aplicação rigorosa dos três métodos explicativos, o autor conclui que o comportamento das organizações envolvidas, bem como o comportamento de alguns indivíduos-chave nos três aspectos principais da crise de 1962, melhor delineiam e explicam o problema, aproximando-se da realidade, reforçando desta forma, a idéia da multiracionalidade dos atores envolvidos enquanto agentes de organizações e enquanto indivíduos.

Embora tratando de assuntos com resultados e conseqüências muito diferentes daqueles tratados na esfera do planejamento de intervenções urbanas, o caminho traçado na teorização ou compreensão de um fato específico na esfera política das relações internacionais é muito semelhante, e Allison conclui brilhantemente que a análise baseada unicamente na racionalidade de um único ator leva a resultados simplistas e perde em complexidade e riqueza de interpretações. 
Na esfera das políticas públicas, Andersen percorre o universo de sua formulação, passando pela tipologia de seus idealizadores e daqueles que efetivamente decidem, chegando a discutir a adoção, implementação e avaliação das mesmas, no ambiente político social dos Estados Unidos dos anos 1970. Reconhece, para a formulação e decisão de políticas públicas, os mesmos modelos que a teoria aplicada ao planejamento urbano define e acrescenta uma abordagem política mais sofisticada, tratando do que ele chama de institucionalismo - teoria das elites e teorias dos sistemas políticos - incluindo o comportamento dos principais atores, quais sejam: os grupos de interesse, os partidos políticos, o executivo, o legislativo, o judiciário, as agências administrativas e o cidadão individual. Suas conclusões apontam para alguns aspectos interessantes:

- o processo de formulação de políticas públicas relativas a problemas de qualquer natureza e magnitude é um ato contínuo, que está sempre sendo modificado no processo de formulação e decisão;

- o processo de formulação de políticas públicas é sempre um processo muito complexo;

- a análise da formulação e decisão de políticas públicas proporciona muita informação e revela a natureza e a operacionalização do sistema político e dos processos políticos em geral e

- uma grande parte do processo no que se refere a como as decisões efetivas sobre políticas públicas são feitas permanece desconhecido e inexplicável ${ }^{15}$.

Finalmente, Andersen acrescenta que estudos de caso são imprescindíveis para iluminar as possibilidades de teorização, pois considera que o conhecimento sobre decisões em políticas públicas ainda permanecia num estágio muito inicial. Também no Brasil, tanto contemporaneamente a Andersen quanto hoje, os estudos de caso que discutem o processo de decisão, tanto sobre políticas públicas como sobre projetos específicos, praticamente não

\footnotetext{
${ }^{15}$ Itens traduzidos e resumidos livremente a partir de ANDERSEN, J. E. Public Policy-Making. New York: Holt, Reinhart and Winston, 1977. 178 p.
} 
existem, com exceção do trabalho que será comentado mais adiante, elaborado em 1974 por Cintra e Gama de Andrade ${ }^{16}$, sobre o processo de planejamento e tomada de decisões no Estado de Minas Gerais. Nesse sentido, o estudo do caso da implantação do sistema metroviário do Rio Janeiro, objeto deste trabalho de investigação, tem por objetivo contribuir para o conhecimento das decisões em políticas públicas.

A escola francesa sobre o tema da decisão aponta o trabalho de Crozier e Friedberg ${ }^{17}$ que, em 1977, apresentam no livro clássico L'Acteur et le Système bases sociológicas para a teorização da multiracionalidade dos atores em toda e qualquer ação coletiva ou sistema, desde a família até sistemas muito complexos como organizações industriais ou sistemas de administração pública, ampliando substancialmente o âmbito da discussão dos autores americanos. Os autores baseiam-se no conceito de que os sistemas são construções sociais e que não existe determinismo nos seus comportamentos já que expressam as decisões individuais de cada ator participante. Envolvendo essencialmente relações de poder em todas as ações, Crozier e Friedberg afirmam que não existe possibilidade de um comportamento racional e determinista coletivo único e que existe sim um comportamento multiracional, permeado de negociação - cooperação e conflito. Concordam com o modelo desenvolvido por March e Simon, na gênese das teorias das organizações, de que as decisões têm lugar num contexto de racionalidade limitada onde as decisões são tomadas de maneira seqüencial e as soluções geralmente adotadas correspondem simplesmente a um mínimo de satisfação. No entanto, os autores enfatizam que o cerne das ações coletivas está nas relações de poder estabelecidas entre atores e que são as organizações que tornam possíveis essas relações de poder e fundamentam sua permanência. As organizações regularizam o desenvolvimento das

\footnotetext{
${ }^{16}$ CINTRA, A. O.; GAMA DE ANDRADE, L. A. Reflexões sobre uma Experiência Estatal. In: CINTRA, A. O.; HADDAD, P. R. (Orgs.). Dilemas do Planejamento Urbano e Regional no Brasil. Rio de Janeiro: Zahar Editores, 1978.

${ }^{17}$ CROZIER, M.; FRIEDBERG, E. L'Acteur et le Système. Paris: Éditions du Seuil, 1977. 437 p.
} 
relações de poder, condicionam a liberdade de ação e orientam o conteúdo das estratégias introduzindo um mínimo de previsibilidade nas ações.

Esses autores trabalham detalhadamente sobre as bases para o conceito de burocracia que tinha sido amplamente discutido em obra anterior de Crozier Le Phénomène Bureaucratique $^{18}$, datada de 1963, baseado em dois casos analisados - o caso das organizações contábeis parisienses e o caso de uma grande empresa industrial pública. Consideram os tipos de poderes dentro de uma organização e reconhecem muitas vezes a existência de uma estrutura de poder paralela, atuando de forma diferenciada da estrutura principal da organização, modelo comumente encontrado na prática da administração pública no Brasil, como no caso da força tarefa criada pelo Presidente Juscelino Kubitschek para a construção de Brasília.

Nesse sentido, este trabalho de pesquisa abordará o papel da burocracia técnica no processo de decisão do Metrô-RJ. A pergunta se esse estamento social foi ou não determinante para a decisão e para as ações posteriores de implantação do sistema deverá ser respondida, bem como qual o arranjo institucional nas diversas esferas da administração que permitiu a tomada de decisão.

Crozier e Friedberg enriquecem as observações de Lindblom referentes à inexistência da decisão em políticas públicas segundo o modelo racional, quando enfatizam a impossibilidade de haver uma vontade geral, clara e unívoca, quando se trata do interesse público. Concluem, no entanto, pelos modelos mistos, ao analisar as experiências americanas do PPBS (Planning Programming Budgeting System desenvolvidas pela Rand Corporation) e suas aplicações na França, o RCB (Rationalisation de Choix Budgétaires), que introduziram práticas e modelos racionais e

\footnotetext{
${ }^{18}$ CROZIER, M. Le Phénomène Bureaucratique. Paris: Éditions du Seuil, 1963. 382 p.
} 
abrangentes para as decisões e escolhas orçamentárias. Nos dois países, apenas resultados muito limitados da prática racional de planejamento puderam ser observados; no entanto, tiveram um efeito orientador sobre a forma aparentemente desestruturada do modelo incremental, baseado na racionalidade limitada de cada ator, determinada pelos seus próprios critérios de satisfação.

Em 1979, interessado no binômio decisão e poder na sociedade francesa, Lucien Sfez ${ }^{19}$ organiza um encontro para discutir essa questão, convidando administradores de empresas públicas, responsáveis por decisões importantes em matéria de política energética, intelectuais em geral que se dedicam à discussão sobre decisões, representantes da administração pública local e nacional e representantes dos setores de informação.

O autor se mostra surpreso sobre os resultados principais do encontro, que ele apresenta da seguinte forma: os agentes das decisões - sejam eles funcionários, jornalistas, políticos - não se reconhecem, por pudor, moral ou modéstia, como agentes do poder. Segundo eles, outra instância detém a chave dos problemas e seu encaminhamento. Embora não exista consenso sobre quem efetivamente detém o poder, todos afirmam que o mesmo está longe deles, conclusão somente em parte semelhante ao seu estudo sobre os transportes na França que viria a ser divulgado em seguida.

$\mathrm{Sfez}^{20}$ no seu livro, também referencial, denominado Critique de la Décision apresenta um arrazoado sobre os três elementos fundamentais da decisão cartesiana: linearidade, racionalidade e liberdade, percorrendo um grande número de autores até o início dos anos 1980. Depois de aprofundar cada um dos elementos cartesianos, Sfez faz uma crítica dos

\footnotetext{
${ }^{19}$ SFEZ, L. Décision et Pouvoir dans la Société Française. Colóquio dirigido por Lucien Sfez. Paris: Union Générale Éditions, 1979. 433 p.

${ }^{20}$ SFEZ, L. Critique de la Decisión. Paris: Presses de la Fondation Nationale des Sciences Politiques, 1981. 392 p.
} 
mesmos, relacionando-os a situações práticas das decisões no final do século XX na sociedade francesa, passando pela teoria do direito, pela cibernética, pela análise do PPBS e do RCB, pela teoria dos sistemas, pelas teorias das organizações, pela psicanálise, pelo modelo histórico e por várias outras áreas do conhecimento. No que se refere à prática do planejamento, Sfez afirma que o planejamento consiste acima de tudo em elaborar programas seqüenciais para dar conta de crises sucessivas. É um método para colocar um pouco de ordem na complexidade presente ${ }^{21}$.

A contribuição mais importante de Sfez é demonstrar que, na realidade, toda essa discussão é estéril e que todas as argumentações críticas dos autores americanos e também de Crozier e Friedberg quanto à racionalidade se referem apenas à linearidade e à abrangência das ações racionais, pois a racionalidade está presente em todos os processos de decisão, incluindo até os comportamentos ditos irracionais discutidos pela anti-psiquiatria.

A interpretação da multiracionalidade dos atores como uma simples justaposição de racionalidades é fortemente rechaçada por Sfez que defende a idéia da existência de racionalidades diferentes dos sub-sistemas e da multiracionalidade do conjunto, criando o que ele chama de "surcode", termo que em português pode ser traduzido como "sobreposição de códigos” ou “código superveniente”, que nada mais é do que a explicitação de uma forma de comportamento resultado do relacionamento e agregação dos comportamentos ou códigos particulares, todos com sua racionalidade específica, que ele chama de liberdade.

Se, para analisar um determinado processo de decisão é necessário fragmentar o tecido vivo e complexo desse processo, organizado segundo uma determinada ordem ou razão, é

\footnotetext{
${ }^{21}$ Ibid. p. 98. Nossa tradução.
} 
absolutamente necessário, paralelamente, seguir toda a imbricação entre os sub-sistemas presentes, como eles se amalgamam ou se anulam, por um efeito de “surcode”. Desta forma, Sfez introduz a idéia de divisão dos atores em vários sub-sistemas desde que toda a relação entre eles seja percorrida, abrindo espaço para uma metodologia de análise dos processos de decisão baseados na multiracionalidade dos atores relacionados entre si.

A partir dessa premissa da sobreposição de códigos de cada ator baseada na liberdade de cada um, Sfez envereda na análise detalhada sobre a prática da decisão na administração pública francesa, descrevendo a situação dos transportes na França, onde indaga quem realmente decide nessa matéria e em quais circunstâncias. O autor conclui que, relativamente aos transportes urbanos da região parisiense, a empresa local - a RATP - afirma não ser responsável pelas decisões que lhe afetam, mas sim a empresa mãe dos transportes ferroviários na França - a SNCF. Esta por sua vez, se diz sem poder, dizendo que é o Ministério das Finanças que decide tudo. Os responsáveis pelo Ministério declaram que na realidade suas ações estão fortemente ligadas às decisões decorrentes dos ministérios militares. Sfez conclui que é sempre muito difícil para um ator ter a real dimensão de seu poder de decisão e que a avaliação de seu desempenho oscila diametralmente, entre liberdade total em suas ações, baseado no modelo racional de conhecimento pleno do assunto tratado, e fatalismo, também total, ao afirmar que na verdade existe uma diluição de responsabilidades e que o poder de decisão é muito pequeno. Nesse sentido, este trabalho tem a pretensão de “fragmentar o tecido vivo e complexo" do processo de decisão do Metrô-RJ, na tentativa de compreender os sub-sistemas presentes e as relações entre os mesmos, identificando os grupos de atores que avaliam sua atuação com liberdade ou fatalismo. 
Anteriormente aos estudos desenvolvidos na França, Robert Dahl ${ }^{22}$, nos Estados Unidos, teoriza sobre quem efetivamente decide, adicionando mais um elemento de enorme complexidade aos condicionantes da decisão, que é a idéia da multi-racionalidade interna/individual dos atores - pluralismo psicológico -, levando a discussão para a individualidade dos atores ${ }^{23}$. Dahl retorna à análise dos grupos sociais afirmando que, no nível local, os americanos conseguiam exercer grande influência nas decisões ao expressar uma pluralidade de interesses através de uma pluralidade de grupos mais ou menos organizados, contrapondo-se à idéia do status quo, baseada no conceito de elite constituída por uma pequena quantidade de empresários que efetivamente decide sobre os assuntos mais importantes.

Aprofundando ainda mais, a análise das decisões dentro das organizações, Michel Ghertman ${ }^{24}$ discorre sobre os processos de decisão nas empresas, ao analisar vários estudos de casos de empresas privadas multinacionais e monta uma tipologia de atores - dentre eles: econômicos, estratégicos e estratégico-internacional - e seus processos decisórios, classificados em administrativo, político, psicológico e cibernético, tirando o foco da racionalidade dos atores (indivíduos ou grupos sociais) para posições mais práticas e próximas do comportamento a se esperar no interior das empresas. O autor inicia uma discussão que se afasta de tentativas de se encontrar padrões para muitas áreas do conhecimento e detalha a especificidade das organizações empresariais.

\footnotetext{
${ }^{22}$ DHAL, R. A. Who Governs? Democracy and Power in an American City. Yale University Press, 1961.

${ }^{23}$ Dahl identifica pelo menos cinco motivações radicalmente diferentes e heterogêneas para as decisões: identificação do ator como sujeito, nível de informação, nível de otimismo/pessimismo, predisposição e objetivos e valores.

${ }^{24}$ GHERTMAN, M. La Prise de Décision. Paris: Presses Universitaires de France e IRM - Institut de Recherche et d'Information sur les Multinationales, 1982, 397 p.
} 
No entanto, Ghertman acena para uma conclusão ainda com abrangência geral: existem ligações entre os processos decisórios empresariais e as transformações sociais e econômicas mais gerais e que as decisões não são analisáveis por elas mesmas, mas elas devem ser examinadas a partir da posição histórica, pré-existente, das empresas. As estruturas analisadas estão sempre em transformação e o autor já observa na época, início dos anos 1980, uma aceleração da globalização do modo de acumulação capitalista. Desta forma, a contextualização política e social passa a ter importância na análise de processos decisórios. No caso do Metrô-RJ, a análise do processo de decisão estará fortemente lastreada no momento político-institucional brasileiro em que ela ocorreu.

Outros autores europeus desenvolvem hipóteses sobre os determinantes do processo decisório, dentre eles Lojkine ${ }^{25}$, Poulantzas ${ }^{26}$ e Castells ${ }^{27}$, dentro de um amplo quadro analítico de discussão das possibilidades de mudança social, adicionando uma análise das transformações nos modos de produção econômica, não analisada pelos demais autores até então. Eles se pautam ainda pela introdução da questão urbana no quadro de referência marxista.

Lojkine, ao analisar a questão da decisão, discorre sobre alguns trabalhos dos principais autores franceses, Sfez e Crozier, e conclui que os mesmos se limitam a caracterizar os atores sociais de acordo com categorias organizacionais, o que é uma postura limitadora, pois exclui toda a análise em termos das classes sociais. Adicionalmente, ao percorrer os autores marxistas, Lojkine indica que não existe liberdade na prática social real e que além das questões estruturais dos modos de produção, devem ser consideradas as questões conjunturais,

\footnotetext{
${ }^{25}$ LOJKINE, J. Le Marxisme, I'État et la Question Urbaine. Paris: PUF, 1977 e Contribution a une Theorie Marxiste de I'Urbanization Capitaliste. Cahiers Internationals de Sociologie, L II, 1972.

${ }^{26}$ POULANTZAS, N. Les Classes Sociales das le Capitalisme Aujourd'hui. Paris: Seuil, 1974. 347 p.

${ }^{27}$ CASTELLS, M. La Cuestion Urbana. Madrid: Siglo XXI de Espagna Editores S.A., 1979. 518 p.
} 
momentâneas, referentes à individualização de uma situação histórica dada, posição também apresentada por Poulantzas.

Poulantzas discorre sobre a formação das novas burguesias - trabalho intelectual -, seu fracionamento em sub-classes, a distribuição de seus agentes e a burocratização do trabalho intelectual, incluindo o papel político e ideológico do saber intelectual. Essa conceituação abre espaço para uma análise das decisões baseada nos conceitos de classes sociais e dentro das classes dominantes, frações sociais com interesses diferenciados.

Castells propõe o estudo das contradições que existem dentro das regras estruturais dos processos de transformação, concentrando-se nas aglomerações urbanas. Assim, segundo Castells, não se pode deduzir da análise da estrutura urbana suas leis de desenvolvimento e transformação através da sua matriz estrutural, mas somente através da análise do processo político. Nessa direção, Castells propõe a análise das unidades urbanas enquanto expressão de estrutura social através do estudo dos cinco elementos que ele propõe como fundamentais da estrutura urbana: produção, consumo, troca, gestão e simbolismo - elementos que se conformam a partir das relações entre eles, dentro das instâncias econômica, político-jurídica e ideológica, suas combinações e as práticas sociais que daí decorrem ${ }^{28}$. Esta abordagem será utilizada na observação do processo decisório relativo ao sistema metroviário da cidade do Rio de janeiro, objeto deste trabalho de investigação, adaptada à situação específica e com fortes considerações sobre o processo político nacional e local.

No Brasil, cabe um grande destaque para o ensaio publicado em 1978, baseado em pesquisa realizada em final de 1974 sobre o processo de planejamento e tomada de decisões no Estado de

${ }^{28}$ CASTELLS, M. La Cuestion Urbana. Madrid: Siglo XXI de Espagna Editores S.A., 1979. 518 p., à p. 475. 
Minas Gerais feito por Cintra e Gama de Andrade ${ }^{29}$. Esses autores demonstram que no contexto de países pobres, a tese de Caiden e Wildavsky ${ }^{30}$ só é parcialmente verdadeira. Estes afirmam que em países com uma grande carência de recursos financeiros, humanos e organizacionais, o planejamento não é a forma mais adequada de atacar os problemas. Somente decisões tomadas de forma incremental, a partir de projetos pequenos e pontuais, que conseguem reduzir as chances de erro e sem a prática do planejamento abrangente - que necessita de um grande volume de recursos -, é que são adequadas às situações de carência encontradas.

Cintra e Gama de Andrade analisam a trajetória das práticas de planejamento e das decisões tomadas no período de 1947 até 1971, período em que o Estado de Minas Gerais passou de extrema carência financeira e organizacional a uma situação de capacidade industrial e gerencial de grande significado nacional, concluindo que as tentativas de planejamento abrangente foram, a princípio, um fracasso, resultando numa total desconexão entre os órgãos implementadores dos projetos propostos, que na realidade se comportaram como se não existisse planejamento algum. No entanto, demonstram também que o planejamento feito num expressivo esforço de racionalidade e linearidade, acabou servindo como uma "agenda de prioridades", na fala dos autores, com grande poder de condução das decisões aparentemente desconexas.

O estudo dos autores brasileiros reforça a tese de Etzioni de que as decisões incrementais são muito mais comuns do que os planejadores, de maneira geral, gostariam que fossem, mas que são as decisões de caráter mais global, abrangentes, que dão um direcionamento para as decisões incrementais. Os autores lembram que certos assuntos de caráter mais geral,

\footnotetext{
${ }^{29}$ CINTRA, A. O.; GAMA DE ANDRADE, L. A. Reflexões sobre uma Experiência Estatal. In: CINTRA, A. O.; HADDAD, P. R. (Orgs.). Dilemas do Planejamento Urbano e Regional no Brasil. Rio de Janeiro: Zahar Editores, 1978.

${ }^{30}$ CAIDEN, N.; WILDAVSKY, A. Planning and Budgeting in Poor Countries. New York: John Wiley, 1974.
} 
nacional, precisam de um rumo mais abrangente e insistem que, embora essas questões possam ter um embasamento técnico, o seu caráter é essencialmente político.

Será visto no decorrer deste trabalho, no caso específico dos transportes urbanos, como decisões aparentemente incrementais, como a decisão de se implantar um sistema metroviário na cidade do Rio de Janeiro, seguiram, na realidade, orientações mais gerais, estabelecidas pelos diversos planos nacionais, em especial pelo II Plano Nacional de Desenvolvimento elaborado para o período de 1975 a 1979.

\subsection{Novos rumos da teoria e da prática a partir dos anos 1980}

Posteriormente a essa discussão sobre o papel dos atores lastreada nos seus interesses muitas vezes conflituosos - que pode ser considerado um marco na teorização sobre a lógica do planejamento e das decisões - e ainda após o desmonte dos caminhos lineares propagados pelos modelos racional-abrangentes de pensamento, o assunto toma outros rumos.

No final da década de 1980, essa discussão parece se extinguir nos Estados Unidos e na França, enquanto tentativa de construção de uma teoria da decisão com algum grau de homogeneidade que possa embasar uma grande variedade de áreas do conhecimento.

Aparentemente, cada disciplina trata de desenvolver as especificidades relativas à sua área de domínio, criando rumos particulares a cada uma delas. 
No que se refere às decisões na esfera pública relativas a grandes investimentos, questão central de interesse deste trabalho, pode-se observar três vertentes importantes de compreensão das práticas de planejamento urbano e de tomada de decisão, discutidas a seguir:

- Vertente 1 - Introdução do conceito de legitimidade e conseqüentemente de novos atores;

- Vertente 2 - Compartimentação da prática de planejamento e

- Vertente 3 - Sofisticação das formas de lidar com a informação.

\subsubsection{Vertente 1 - Ampliação do conceito de legitimidade e conseqüentemente introdução de novos atores}

Em primeiro lugar, pode-se observar a ampliação do conceito de legitimidade no planejamento $^{31}$ e na tomada de decisões, baseada principalmente na participação das comunidades nas decisões sobre os seus futuros, que se inicia nos anos 1960 nos Estados Unidos, com os planos de renovação urbana elaborados na esfera federal e com a formação de associações de moradores que não se sentiram adequadamente contemplados por esses planos, mas que se consolida nos anos 1980. Passam a ficar explícitos os eventuais conflitos entre as noções de interesse público generalizado com as de interesse da comunidade organizada. Nesse sentido, é de grande interesse o texto de Paul Davidoff ${ }^{32}$ que apresenta uma argumentação que veio a embasar importantes mudanças nas práticas do planejamento. Ele afirma que o planejador, além de explicitar os valores existentes nas soluções escolhidas, ele deve ser o

\footnotetext{
${ }^{31} \mathrm{O}$ conceito de legitimidade aqui apresentado é considerado de forma mais ampliada do que o conceito de Norberto Bobbio, no seu Dicionário de Política, verbete Legitimidade, que o define como o elemento que confere eficácia ao poder estatal e ao seu ordenamento jurídico. Afirma que todo Estado, para existir, precisa de um mínimo de eficácia e, portanto, de legitimidade. Todo Estado existente é considerado legítimo quando possui o mínimo de consenso necessário para existir, para que seu poder seja eficaz e que seu ordenamento jurídico tenha validade. Consideramos que além do Estado, os próprios usuários/atingidos possam cuidar de seus interesses, ampliando a legitimidade do planejamento feito pelos agentes públicos.
}

${ }^{32}$ DAVIDOFF, P. Advocacy and Pluralism in Planning. In FALUDI, A. (Org.) A Reader in Planning Theory. New York: Pergamon, 1973. Primeiramente in: Journal of the American Institute of Planners, no. 31, nov. 1965. 
defensor daquilo que ele acha correto. Acrescenta que um plano não necessariamente conseguirá representar um consenso, em função dos diferentes interesses presentes numa comunidade, e que existe espaço para o profissional planejador que compreenda e defenda soluções alternativas aderentes a grupos discordantes, sejam eles quais forem.

Nesse sentido, a autoridade política local deve acolher, não apenas os planos oficiais, mas também aqueles construídos por grupos organizados que defendam seus próprios interesses. É uma prática que ele denomina de Planejamento Plural nos quais o profissional planejador desempenha o papel de um advogado, defendendo os interesses dessa fatia da comunidade, cujos interesses e valores possam ser claramente identificados. Só assim poderá haver legitimidade no planejamento ${ }^{33}$, e alternativas de solução realmente diversas poderão ser analisadas e escolhidas, num processo sadio de competição entre elas.

Acredita Davidoff que, desta forma, atinge-se o mais alto grau de legitimidade e de possibilidades de que as decisões efetivamente sejam inclusivas. Afirma ainda que o papel do profissional planejador além de técnico e político, deve ser também educativo, ao trabalhar diretamente com as comunidades ou associações organizadas. Inclui dentre os grandes grupos a serem favorecidos com essa prática do planejamento plural, as minorias raciais, as famílias de baixa renda, os grupos por direitos civis e também aqueles mais bem estruturados na defesa de seus interesses, como as câmaras de comércio, os empreendedores imobiliários e as organizações sindicais.

\footnotetext{
${ }^{33}$ Na visão de Davidoff, as atividades de planejamento são vistas de forma ampla, aí incluso o planejamento setorial, mesmo que não tenha uma abrangência estritamente local ou comunitária, como o planejamento dos transportes.
} 
Finaliza suas inovadoras colocações afirmando que quem deve pagar pelos planos plurais ou alternativos é a própria administração pública; no caso dos Estados Unidos, ele propõe que seja o Governo Federal a assumir a viabilização financeira dessas propostas alternativas. Aponta novos caminhos para a profissão dos planejadores urbanos, dizendo que eles poderão efetivamente atuar nos grupos cujos interesses sejam semelhantes aos seus e que esse caminho significa uma grande alteração na formação profissional desses agentes. Finalmente, defende que a prática do planejamento urbano deve ser alçada a uma esfera de entendimento mais geral, incluindo as vertentes econômicas e sociais e não apenas, ou especialmente, a dimensão físico-territorial dessa prática.

Nos Estados Unidos, as ações de mobilização e de participação social começam a despontar com a criação dos CDC - Community Design Centers $^{34}$, em meados dos anos 1960, cujo objetivo era a assessoria em assuntos de arquitetura e planejamento sem custo para comunidades ou indivíduos que não pudessem pagar por esse tipo de serviço. Fortemente lastreados nas idéias de Davidoff, o primeiro CDC foi o ARCH - Architects Renewal Committee in Harlen, que começou suas atividades em 1964 com trabalho voluntário e que em 1967 já era financiado pelo OEC - Office of Economic Opportunity, instituição governamental, para possibilitar às comunidades o desenvolvimento de seus próprios planos e políticas, em especial aqueles que se contrapunham às políticas públicas de renovação urbana (formuladas “de cima para baixo”), num formato de defesa dos interesses das comunidades. Outros CDCs surgiram, também com missões muito claras, o Metro Link em Nova Orleans, por exemplo, que defendia uma substancial relocação de recursos - bens, infra-estrutura e terra - para benefício direto dos pobres e das minorias. Em menos de quatro anos, o número de CDCs cresceu rapidamente, chegando a 74 em operação em 1.971.

\footnotetext{
${ }^{34}$ WEISS, Z. City Design Centers - Mechanism for Citizen Participation in the Planning Process. ASPO Planning, 1971. p. 132-151.
} 
No Brasil, observa-se esse movimento crescente a partir dos anos 1980, coincidente com o processo de redemocratização do país, cujo contexto será detalhado no item 1.3. Embora de forma nacionalmente muito desbalanceada, algumas administrações municipais lograram definir rumos para algumas políticas públicas e implantação de projetos de forma socialmente mais legítima, através da participação efetiva de associações de moradores e outros grupos organizados.

Na área ambiental, a obrigatoriedade de disponibilização para o público dos Relatórios de Impacto no Meio Ambiente - RIMA, e a possibilidade de promoção de audiências públicas para informação sobre projetos e seus impactos ambientais e para discussão do RIMA, foram regulamentadas pelo CONAMA - Conselho Nacional do Meio Ambiente ${ }^{35}$ em $1986^{36}$, tornando o processo decisório mais transparente e participativo, saindo da exclusividade dos gabinetes dos agentes de decisão. Existem alguns exemplos de alterações substanciais de projetos já praticamente decididos, em função da presença de grupos organizados em torno de reivindicações claras, muito embora esse direito não seja freqüentemente exercido e muitas vezes as audiências públicas sejam eventos com pouca repercussão, realizados apenas como exigência legal. Um exemplo de decisão integralmente barrada em debates populares é o caso da construção da Rodovia do Sol, que cruzaria a Serra do Mar, no litoral Norte do Estado de São Paulo. Outro caso muito recente de prática participativa, mas que não logrou obstar a decisão, já tomada na esfera federal, pela implantação do empreendimento, é o do projeto de reversão de parte das águas do rio São Francisco. Nas audiências públicas para a análise dos impactos desse projeto, governos estaduais, municipais e organizações populares e de proteção ambiental se posicionaram contra o projeto e seus impactos, o que, no entanto, não resultou em

\footnotetext{
35 BRASIL. Resolução CONAMA no. 1., de 23 jan. 1986, artigos 9. e $11^{\circ}$.

${ }^{36}$ No Brasil, a Lei Federal 6.928/81 que cria o SISNAMA - Sistema Nacional do Meio Ambiente passou a ser efetivamente praticada a partir da Resolução CONAMA 01 em 1986 que a regulamenta, criando um caminho de participação da população nas decisões relativas ao meio ambiente. Isto se dá 17 anos depois das iniciativas de mesma natureza nos Estados Unidos, com o NEPA, National Environment Policy Act, estabelecido em 1969.
} 
influência significativa para impedir o fornecimento da Licença Prévia e nem mesmo na promoção de modificações ou compensações significativas. Concomitante à realização das consultas populares, o detalhamento de projetos estava sendo feito, assim como a compra de materiais para as obras ${ }^{37}$. É assunto de debate nos meios acadêmicos a eficácia de consultas populares tanto no reforço às decisões como com relação às reais oportunidades de obstá-las.

O Estatuto da Cidade ${ }^{38}$, Lei Federal 10.257 aprovada em 10/07/2001, traz a obrigatoriedade para a esfera municipal de implementar alguns instrumentos de planejamento que incluem a participação da sociedade nas decisões sobre as cidades. Assim, o inciso III do seu artigo $4^{\circ}$. indica a utilização da gestão orçamentária participativa, dentre os instrumentos da política urbana municipal. Algumas prefeituras, como a de Porto Alegre ${ }^{39}$, lograram, com mais ou menos sucesso, definir uma prática de planejamento e de decisão mais próxima dos grupos sociais - comunidades, movimentos e entidades da sociedade civil ${ }^{40}$-, tanto beneficiados quanto excluídos, muitas vezes organizados territorialmente, obrigando a explicitação de conflitos reais num confronto prévio à tomada de decisão sobre o orçamento municipal.

No seu artigo $43^{\circ}$., no Capítulo IV - da Gestão Democrática da Cidade, o Estatuto prevê que os instrumentos que garantem a gestão democrática da cidade são ${ }^{41}$, dentre outros, debates,

\footnotetext{
${ }^{37}$ Ver amplo material na grande imprensa no início de 2005, que antecedeu a expedição da Licença Prévia.

${ }^{38}$ BRASIL. Lei Federal no. 1.257: Estatuto da Cidade, de 10 jul 2001.

${ }^{39}$ CÂMARA DOS DEPUTADOS (Comissão de Desenvolvimento Urbano e Interior); SECRETARIA ESPECIAL DE DESENVOLVIMENTO URBANO DA PRESIDÊNCIA DA REPÚBLICA; CAIXA ECONÔMICA FEDERAL; INSTITUTO POLIS. Estatuto da Cidade - Guia para implementação pelos municípios e cidadãos. Brasília: Câmara dos Deputados - Coordenação de Publicações, 2a . ed., 2002. 273 p.

${ }^{40}$ BRASIL. Lei Federal no. 1.257: Estatuto da Cidade, de 10 jul 2001, op. cited, parágrafo $3^{\circ}$. do art. $4^{\circ}$.

${ }^{41}$ Ibid., artigo $43^{\circ}$, onde reza que os instrumentos que garantem a gestão democrática da cidade são: "I - órgãos colegiados de política urbana, nos níveis nacional, estadual e municipal; II - debates, audiências e consultas públicas; III - conferências sobre assuntos de interesse urbano, nos níveis nacional, estadual e municipal;[..]."
} 
audiências, consultas públicas e conferências, todos de caráter inclusivo e com capacidade de efetivamente influenciar as decisões.

A mesma Lei Federal obriga o executivo municipal a elaborar o Plano Diretor, cabendo aos poderes legislativo e executivo garantir a promoção de eventos - audiências públicas e debates - com a participação da população e de associações representativas dos vários segmentos da comunidade, bem como a publicidade e o acesso aos documentos e informações produzidos.

Muitos são os críticos das práticas de implementação da participação social, que argumentam que, a despeito do número de eventos, e da forma de organização e dinâmica dos mesmos, ainda se está muito longe de fazer interessar a uma grande parcela da população assuntos de grande relevância como impactos ambientais, orçamento e Planos Diretores ${ }^{42}$. No caso específico do Metrô-RJ, a presença de associações comunitárias que pudessem ter exercido alguma influência no processo de decisão pelo sistema foi investigada.

De grande interesse, concernente à inclusão de novos atores nos processos de planejamento e de decisão mais recentes, são os estudos que discutem políticas lastreadas no planejamento da demanda e no comportamento dos usuários em contraposição às políticas concebidas a partir do planejamento da oferta; estas partem do pressuposto de que um incremento na demanda sempre deve ser atendida pelo aumento da oferta.

\footnotetext{
${ }^{42}$ Ver artigo de Flávio Villaça: Sem os Erros do Presente. Tendências/Debates, A3, Folha de São Paulo, 20 maio 2005, sobre o Plano Diretor de São Paulo.
} 
Segundo Gordon McGranahan ${ }^{43}$ que trata da questão da água para abastecimento humano, a reflexão sobre o planejamento pela demanda começou nos Estados Unidos nos anos 1980, contradizendo o axioma da "demanda obrigando a oferta” e tratando de questões antes não mencionadas, tais como o aumento na eficiência no uso da água e redução de perdas. Ele parte do pressuposto de que medidas de racionalização da demanda têm a mesma importância de ações para aumento da oferta e também de que os benefícios podem se estender a todos numa situação de escassez ou de conservação dos recursos naturais ${ }^{44}$.

Na área de transportes, mais especificamente de circulação urbana, pode-se observar, também a partir dos anos 1980, uma mudança estrutural no aporte de soluções e no processo decisório quanto aos problemas de tráfego e congestionamento do sistema viário. Ao se constatar (dirigentes e usuários) que na maioria das grandes cidades do mundo o uso do transporte individual por automóvel apresentava um ritmo crescente e que não se poderia aumentar a capacidade do sistema viário indiscriminada e infinitamente, ofertando os espaços exigidos por essa opção modal, também na lógica da demanda obrigando a oferta, iniciou-se um movimento de reflexão, a nível mundial, sobre as possibilidades de se conceber soluções que pudessem reduzir a demanda pelo automóvel, orientando viagens para outros modos transporte coletivo (público e privado), bicicletas, viagens a pé, viagens em grupo e outros.

\footnotetext{
${ }^{43}$ MCGRANAHAN, G. Demand-Side Water Strategies and the Urban Poor. IIED International Institute for Environment and Development, PIE Series no. 4. Stevenage, U. K.: [s.n.], 2002, 67 p.

${ }^{44}$ Hoje, pode-se observar uma mudança no paradigma do uso da água, constando-se também que medidas de planejamento da demanda têm sido praticadas em várias situações e em diversos países. No entanto, embora a visão geral venha ganhando aceitação, a forma de praticá-la é ainda desigual com relação ao usuário final; de forma que as comunidades mais carentes ao se inserirem nos preceitos do planejamento da demanda são muitas vezes discriminadas na oferta do serviço. Ainda, McGranahan afirma que no trato da questão do abastecimento de água para consumo humano, organizações burocráticas tendem a aplicar um alto grau de racionalidade no comportamento humano: plano ideal, governo define os objetivos, especialistas decidem como o sistema de abastecimento de água deve ser concebido para atingir esses objetivos e as autoridades públicas asseguram que essas decisões sejam implementadas. Essa abordagem não tem conseguido avançar no interesse da conservação do recurso e menos ainda no suprimento de água para que comunidades carentes recebam um mínimo de água necessário para atingir objetivos de saúde pública. A abordagem através das associações voluntárias e/ou comunitárias parece levar a resultados que se aproximam mais dos interesses dos grupos menos favorecidos, embora dependam fortemente da oferta de água bruta que geralmente ainda é planejada de maneira centralizada.
} 
Ao longo do tempo acrescentou-se às necessidades de redução de congestionamentos, objetivos mais amplos de natureza sócio-ambiental, como redução de consumo de combustíveis, redução da poluição veicular, melhorias na saúde, segurança nos deslocamentos de veículos e de pedestres e outras - transporte sustentável.

O conjunto de medidas operacionais que pretendem atender os objetivos diretamente relacionados com a redução e redirecionamento da demanda no seu sentido mais amplo é conhecido hoje como Transportation Demand Management - TDM (gestão da demanda em transportes urbanos ou ainda, gestão da mobilidade urbana). Foi nas cidades européias, premidas pelas dificuldades de ampliação sistemática do sistema viário, que ocorreram experiências pioneiras no sentido de responder às necessidades de deslocamento através da gestão da demanda. Mas é nos Estados Unidos, onde grande parte das cidades surgiram ou se expandiram já sob o domínio do transporte individual, que as experiências vêm sendo sistematizadas e que governos municipais e até mesmo estaduais vêm trabalhando no sentido de propor e implementar planos que possibilitem uma sinergia de ações e que evitem efeitos perversos na aplicação de medidas aparentemente adequadas mas que podem vir a comprometer aspectos não abordados.

A Victoria Transport Policy Institute - VTPI ${ }^{45}$, instituição de pesquisa independente, mantém uma enciclopédia on-line sobre TDM, de acesso livre, que contém um inventário de práticas organizadas em grandes grupos temáticos: 1. para melhorar opções de transporte $^{46} ; 2$.

\footnotetext{
${ }^{45}$ Organização de pesquisa não governamental dedicada ao desenvolvimento de soluções práticas e inovadoras para os problemas de transporte. Além de pesquisas específicas sobre vários temas e cidades, ela mantém a VICTORIA TRANSPORT POLICY INSTITUTE. TDM Encyclopedia. Disponível em: $<$ http://www.vtpi.org/tdm/tdm12.htm>, Acesso em: 22 jul 2008.

${ }^{46}$ Entre as medidas apresentadas para melhorar as opções de transporte estão: melhorias no trânsito, opções de transporte não motorizados, pesquisas sobre carros movidos a energia elétrica, carona solidária, horários de trabalho flexíveis, “car sharing” (carros compartilhados), bicicletas públicas, tele-trabalho, melhorias nos taxis, integração do fluxo de bicicletas no trânsito em geral, carona garantida, racionamento do espaço urbano através
} 
incentivos para o uso de modos alternativos e redução do transporte individual ${ }^{47}$; 3 . gestão do uso do solo e estacionamento ${ }^{48}$ e 4 . políticas institucionais - concepção e reformulação ${ }^{49}$. Indica também quais práticas atendem a determinados objetivos, estratégias de interesse para grupos sociais específicos e métodos de avaliação e planejamento. Os estudos do VTPI reforçam a idéia de que os melhores resultados na aplicação de um programa de TDM inclui uma combinação de práticas adequadas para cada cidade.

Vários estados, como a Flórida e Washington ${ }^{50}$, elaboraram seus planos de redução do uso do transporte individual, enquanto muitas cidades estão em vias de aprovar e implementar planos locais. Destacam-se os esforços de formação de profissionais para atuarem nos governos, empresas e organizações do terceiro setor, dentro da visão de Gestão pela Demanda, e, um exemplo importante é o curso Florida Commuter Choice Certificate Program ${ }^{51}$ na University

de rodízio de veículos, realocação do espaço viário para outros modos, informação em tempo real sobre a condição das vias e sobre itinerários dos sistemas de transporte coletivo, resposta rápida a acidentes, vias exclusivas para carros com mais de uma ou duas pessoas e outras.

${ }^{47}$ Entre os incentivos para o uso de modos alternativos e redução do transporte individual estão: pedágio em rodovias, valores de pedágios adequados às distâncias percorridas, taxas de congestionamento, pagamento de estacionamentos, impostos sobre combustíveis, subsídios ao uso de transporte coletivo para funcionários e outras.

${ }^{48}$ Entre as medidas relativas a gestão do uso do solo e estacionamentos estão: crescimento inteligente, “new urbanism”, planejamento do crescimento urbano nos vetores de maior interesse/eficiência, gestão de estacionamento, planejamento sem automóveis, "traffic calming”, requalificação de espaços públicos para pedestres e bicicletas, obrigações de gerir a demanda dos moradores/usuários de novos empreendimentos e outras.

${ }^{49}$ Sugestões quanto a políticas e programas institucionais compreendem: programas de gestão da demanda em geral, programas de redução de viagens, gestão de transporte de grandes pólos geradores (hospitais, universidades, distritos industriais), gestão do transporte por caminhões, gestão de transporte para o turismo e outras.

${ }^{50}$ O Estado de Washington elaborou em 1991 o primeiro programa de TDM dos Estados Unidos: MUNICIPAL RESEARCH AND SERVICES CENTER OF WASHINGTON. Washington State's Commute Trip Reduction Program. Disponível em < http://www.mrs.org/subjects/transpo/TDM.aspx> Acesso em 20 set. 2008.

${ }^{51}$ Programa acadêmico integralmente voltado para as questões de gestão da demanda em transportes urbanos trazendo conceitos e experiências em modos alternativos ao transporte individual: ferramentas, técnicas, planejamento e avaliação, campanhas de mercado, formação de multiplicadores, políticas públicas, legislação. Informações encontradas na página oficial do Center for Urban Transportation Research

< http://www3.cutr.usf.edu/tdm> Acesso em: 26 set. 2008. O Center for Urban Transportation Research elaborou 
of South Florida e todo o trabalho de pesquisa desenvolvido pelo Center for Urban Transportation Research, também da University of South Florida.

Na Europa, destacam-se os esforços da Inglaterra, com grande ênfase nas medidas implementadas por empresas enquanto grandes pólos geradores de tráfego - como universidades, hospitais, aeroportos, empresas com número elevado de funcionários, centros empresariais - que incluem incentivos e desincentivos como oportunidades de tele-trabalho, horários de trabalho flexíveis, compartilhamento de automóveis, uso de bicicleta, limitação de estacionamento, dentre outros. A apresentação de um Travel Plan é uma das exigências de licenciamento para expansão de empreendimentos. Também são de reconhecida eficácia nesse país as iniciativas governamentais do tipo pedágio urbano.

De grande sucesso são os programas de car-sharing, especialmente na Suíça e na Alemanha ${ }^{52}$, com carros para locação em diversas partes da cidade e facilidades para reserva, retirada e entrega de veículos; o usuário paga o que efetivamente utiliza. Na França, mais especificamente em Paris, em 2007 foi implantado o Programa Vélolib, de bicicletas públicas distribuídas pela cidade, que podem ser destravadas a partir de passe eletrônico prépago. São cerca de 20.000 bicicletas e cuja utilização é paga com valores muito baixos. Este programa foi em grande parte assumido pela iniciativa privada. No entanto, só pôde ser efetivamente implantado após extensiva adequação de muitas vias da cidade para receber faixas segregadas para as bicicletas. Na Dinamarca é amplamente difundido o uso de bicicletas, e as metas em várias cidades é de chegar a 30\% do número total de viagens até

em Setembro de 2005 uma pesquisa extensiva no estado da Flórida sobre o uso da bicicleta, com foco nas medidas necessárias para que moradores mudassem seus hábitos nessa direção.

52 Segundo o CENTER FOR URBAN TRANSPORTATION RESEARCH. TDM in Europe - a Synthesis of Research Findings: Annotated Bibliography of TDM in Europe. Disponível em http://www3.cutr.usf Acesso em: 22 set. 2009, existiam em operação no ano de 2001, cerca de 100 companhias de car-sharing em 11 países da Europa: Áustria , Dinamarca, Finlândia, França, Grécia, Alemanha, Itália, Holanda, Noruega, Suíça, Suécia e Inglaterra. Na França existe o programa Smart. 
2010; em Copenhagen esse modo chegou a 34\% das viagens no ano 2000. Existe também um grande número de cidades européias que participam de uma rede de incentivo ao transporte público, ao uso de bicicletas e à implementação de espaços atraentes para as viagens a pé, denominado Programa Car Free Cities.

Na Bélgica, na cidade de Hasselt - com 68.000 habitantes no ano 2000 -, o planejamento da oferta de sistema viário previa a construção de um terceiro anel viário. Optou-se por requalificar o segundo anel já existente, eliminando algumas faixas para automóveis, para nelas se implantar transporte público e espaços para bicicletas e pedestres. Como incentivo para essa mudança estrutural, ofereceu-se gratuidade no transporte público nesse novo percurso.

Em outros países - Nova Zelândia, Austrália, Coréia do Sul, Japão, Grécia, Nigéria, Ottawa, Singapura, Hong Kong e outros - são conhecidas várias experiências de sucesso nas seguintes modalidades: rodízio de veículos por final de placa, planejamento de congestionamentos (semáforos nas entradas de vias expressas e túneis), pedágio urbano, taxas expressivas para proprietários de veículos (também em componentes para montagem e manutenção e nos combustíveis). No entanto, nesses locais essas medidas são pontuais e praticamente não existem planos integrados que sugiram a implementação de medidas complementares e com efeitos sinérgicos.

Cabe observar que muitas ações são de iniciativa governamental, com o intuito de equilibrar os esforços necessários para aumentos de oferta e redução ou redirecionamento da demanda. No entanto, a formação de organizações sociais independentes para lidar com o interesse dos usuários do transporte urbano vem sendo estimulada para que soluções possam nascer e até mesmo serem implementadas de forma independente das ações de governo. Ainda, iniciativas por parte de 
empregadores, de grande incidência na Europa, vem sendo incentivadas ou até mesmo tornadas obrigatórias no sentido de racionalizar a demanda por transporte por parte dos trabalhadores. Na Austrália, o Programa TravelSmart é de iniciativa comunitária e encoraja pessoas a escolher outros modos de transporte na cidade de Perth. O programa parte de pesquisas feitas com usuários que indicam que pelo menos 15\% das viagens feitas por automóvel são facilmente transformáveis em viagens a pé. Em Zurique, na Suíça, já existe uma tradição de referendos populares para a decisão sobre a implantação de grandes projetos de infra-estrutura.

No Brasil, iniciativas de gestão pela demanda vêm sendo implementadas nos últimos 30 anos, em várias cidades, embora de maneira pontual e desestruturada. Destacam-se:

- de natureza mais geral: taxação de carburantes, impostos sobre o uso de veículos automotores, desenvolvimento de motores “flex - gasolina e alcool”, produção de biocombustíveis;

- regras de uso do solo: obrigatoriedade de vagas de estacionamento na construção e/ou licença de funcionamento de atividades, relatórios de impacto de vizinhança que incluem impactos sobre o tráfego;

- de caráter físico: pistas segregadas para ônibus, implantação de estacionamentos para automóveis e para bicicletas junto às estações de metrô; fechamento de trechos de sistema viário para utilização como áreas de lazer nos finais de semana; implantação de ciclovias; áreas exclusivas para pedestres em áreas de grande movimentação; melhorias em calçadas em geral;

- de natureza gerencial e organizacional: integração tarifária; vale-transporte; ônibus fretados com destino para regiões de grande concentração de empregos; rodízio de veículos (incluindo caminhões) em horário de pico, por final de placa, em áreas de maior tráfego; possibilidade de transporte de bicicletas em vagões selecionados do Metrô nos finais de semana. 
Mais recentemente, a partir de exigência do Estatuto da Cidade de que cidades com população maior do que 500.000 habitantes tivessem em seus Planos Diretores um capítulo sobre transportes, o Ministério da Cidade lançou o PLAN MOB - Construindo a Cidade Sustentável $^{53}$, caderno de referência para estimular e orientar os municípios na elaboração dessas regras legais. Tem por base os princípios estabelecidos na Política Nacional de Desenvolvimento Urbano e na Política Nacional de Mobilidade Urbana Sustentável, principalmente na reorientação do modelo de urbanização e de circulação - projeto de lei que institui, no sentido de obrigar, uma visão mais integrada da questão dos transportes urbanos nas cidades brasileiras. Afirma novos conceitos e princípios gerais para o planejamento da mobilidade urbana, deixando ao gestor público local as especificidades de sua cidade. Contém, no entanto, orientações precisas sobre metodologias e formas de organização dos trabalhos.

Cabe observar um início de interesse dos profissionais brasileiros sobre um direcionamento da visão dos transportes urbanos considerando-se a gestão da demanda, como afirma Rogério Belda em artigo no jornal O Estado de São Paulo, 08/03/2008, Mas, afinal, qual Pedágio Urbano, embora a discussão e formação acadêmica no assunto em nosso país esteja apenas começando. Belda cita o interesse da Prefeitura de São Paulo em estudos junto com o Banco Mundial que considerem medidas de gestão da demanda.

O estudo do caso da implantação do sistema metroviário do Rio de Janeiro considera a inserção do projeto numa visão mais ampla de planejamento dos transportes urbanos, discutindo se a decisão pelo empreendimento considerou aspectos relativos ao planejamento pela demanda ou se não vislumbrou ações nessa direção, partindo exclusivamente da oferta.

\footnotetext{
${ }^{53}$ MINISTÉRIO DA CIDADE, Secretaria Nacional de Transporte e da Mobilidade Urbana. PLAN MOB Construindo a Cidade Sustentável. Caderno 1 - Caderno de Referência para Elaboração de Plano de Mobilidade Urbana, 2007. 180 p.
} 


\subsubsection{Vertente 2 - Compartimentação da prática do planejamento}

Em segundo lugar, observa-se uma compartimentação da prática do planejamento, baseada em grandes temas com objetivos previamente estabelecidos, em nome dos quais as idéias e as decisões vão sendo encaminhadas, considerando-se a existência de um certo consenso geral. Surgem na década de 1980 e persistem até os dias de hoje, tanto nos Estados Unidos como nos países da Europa, a explicitação de métodos de planejamento e de decisão circunscritos a temas específicos baseados em objetivos previamente aceitos, como por exemplo, as noções de planejamento para as minorias, planejamento para os gêneros, planejamento para a reabilitação e recuperação de áreas urbanas deprimidas, planejamento para o desenvolvimento sustentável, planejamento do bem estar social, planejamento da moradia, planejamento dos transportes e outros.

Essa compartimentação do planejamento segundo áreas com objetivos previamente aceitos pode ser efetivamente observada na evolução das escolas de planejamento urbano, que passam a oferecer um conjunto de disciplinas voltados para assuntos cujo recorte é o entendimento prévio de sua finalidade e do consenso quanto ao tipo de atuação ${ }^{54}$. Desta forma, pode-se dizer que existe um movimento de formação do profissional de planejamento que vai atuar como propositor e advogado de um conjunto de idéias com algum grau de

\footnotetext{
${ }^{54}$ Segundo WAKELEY, P. Notes on the History of the Development Planning Unit. Londres: DPU, 2005. 24 p. O DPU - Development Planning Unit da University College of London, nos anos 1980 e 1990, passa a oferecer cursos como: planejamento com mulheres para o desenvolvimento (precursor do planejamento de gênero - gender planning); habitação no desenvolvimento; gerenciamento de centros urbanos; teoria e prática do desenvolvimento sustentável; desenvolvimento das áreas peri-urbanas, dentre outros. Ainda, conforme informações disponíveis em: <http://www.sppsr.ucla.edu> Acesso em: 15 mar. 2006, o Department of Urban Planning, da School of Public Affairs da UCLA - University of California Los Angeles, oferece disciplinas como Fundamentos da Política de Bem Estar Social, Raça, Gênero, Cultura e Cidades, Moradores de Rua: Moradia e Serviço Social, Mulheres e Desenvolvimento Comunitário, dentre outros cursos mais gerais enquadrados como de planejamento.
} 
consenso social, embora as particularidades da realidade de cada caso concreto ainda deixem espaço para muitas discordâncias.

No caso específico do planejamento de transportes no Brasil, existiu e ainda persiste um movimento de setorialização tanto na formação acadêmica e profissional quanto na prática, com uma compreensão do tema ainda fortemente orientada pela oferta das redes e dos

serviços. É predominantemente nas escolas de engenharia que se dá a formação específica e não junto aos grupos de planejamento urbano, que discutem a cidade como um todo.

As estreitas relações entre planejamento de transportes e políticas de desenvolvimento urbano são pouco discutidas até hoje e eram assuntos particularmente dissociados durante o período de investigação deste trabalho. Com exceção dos eixos de transporte coletivo viabilizados em Curitiba nas décadas de 1970 e 1980, as opções por modos, tecnologia e localização dos sistemas de transportes urbanos não eram discutidas dentro de uma visão de modelo de desenvolvimento mais geral das cidades brasileiras. Neste sentido, o caso da implantação do sistema metroviário na cidade do Rio de Janeiro é particularmente revelador das práticas de planejamento setorializadas.

\subsubsection{Vertente 3 - Sofisticação das formas de lidar com a informação}

Em terceiro lugar e de grande importância, observa-se o expressivo desenvolvimento de técnicas de planejamento baseadas em grande sofisticação nas formas de lidar com a informação. Algumas dessas técnicas pretendem a inclusão de vários agentes e interessados no processo decisório, mesmo que os mesmos sustentem posições de conflito. Com o advento e a disseminação dos apoios computacionais, a utilização tanto de técnicas de tratamento de 
informações e modelagem - que incluem uma grande variedade de componentes - quanto de instrumentos capazes de operar problemas complexos vem tomando um espaço considerável nas práticas de planejamento em várias áreas do conhecimento. Nos assuntos de natureza urbanística, com o tratamento de dados censitários, com mapeamento digital, com a utilização de sofisticados modelos computacionais e com o uso de satélites, ressalta-se a natureza técnica da prática do planejamento. A busca da melhor informação possível traz de volta o dilema dos anos 1970 - a incapacidade do planejamento ter uma natureza abrangente e exaustiva -, resultando no movimento pela melhor solução, aquela irrefutável, obtida através das melhores informações e, conseqüentemente, a maior racionalidade das soluções e possíveis alternativas, lastreando o processo decisório e praticamente impondo a solução.

Nos Estados Unidos, grande ênfase tem sido dada ao desenvolvimento de sistemas de apoio à decisão, tais como tecnologia dos sistemas informacionais, estatística aplicada à Gerência da Decisão (Managerial Decision), e ainda técnicas de melhorias no entendimento dos processos de decisão individual e grupal em organizações. Suas aplicações têm sido feitas especialmente em organizações privadas, tendo ainda pouca repercussão nas decisões tomadas na esfera pública com relação a grandes investimentos.

Técnicas de idealização do futuro têm especial interesse, com possíveis aplicações no planejamento de uma região e de uma cidade, como Myers e Kitsuse ${ }^{55}$ apontam através do relato sobre técnicas que têm sido usadas em muitos estudos, tais como: projeções, previsões, antevisões, construção de cenários, tendências históricas assemelhadas, dinâmica de ciclos vitais, ficção científica e histórias convincentes. Os autores concluem que, embora seja muito importante para o planejador a construção de um futuro possível, os resultados são ainda

\footnotetext{
${ }^{55}$ MYERS D. e KITSUSE, A. Constructing the Future in Planning: a Survey of Theories and Tools. Journal of Planning Education and Research. p. 221-231, v. 29. Summer 2000.
} 
muito superficiais e até mesmo vazios; e por uma razão muito simples: trabalhando com o futuro e portanto com suposições, os profissionais se vêem constrangidos a apresentar posições que não venham a ser facilmente contestadas - exigência que questiona a própria essência dos estudos sobre o futuro. Observa-se ainda pouco esforço por parte da academia em desenvolver procedimentos para idealizar ou representar o futuro. No entanto, procedimentos para se construir alternativas de futuro de forma que uma comunidade possa trabalhar no sentido de buscar um caminho de interesse comum, parece ser um rumo interessante, se o objetivo for o de aumentar as possibilidades de se influir nas decisões.

Na área de meio ambiente, de transportes, dos recursos hídricos e de várias outras áreas do conhecimento, quando existe uma obrigatoriedade de se refletir sobre dados de natureza muito diversa e de grande complexidade, existe um avanço expressivo no desenvolvimento de técnicas de apoio à decisão, na medida em que elas possibilitam a comparação de alternativas com grande número de variáveis de diferentes naturezas, são os MMAD - Modelos Multicritérios de Análise de Decisão organizados em várias famílias de métodos conforme suas características básicas. Dentre eles destacam-se o MACBETH - Measuring Attractiveness by a Categorical Based Evaluation Technique desenvolvido por Bana e Costa e Vansnick em meados da década de 1990. Existem ainda o PROMETEE - Preference Ranking Organization Method for Enrichment Evaluation, que conta com diversos procedimentos adaptados a problemas diferenciados, o ELECTRE - Élimination et Choix Traduisant la Realité, da escola francesa, também em várias versões e ainda o AHP Saaty - Analytical Hierarchy Process ${ }^{56}$, em versão SAATY for Windows, e outros. Esses modelos vêm recebendo contribuições para os seus aperfeiçoamentos, especialmente por parte de

\footnotetext{
${ }^{56}$ Desenvolvido por Thomas L. Saaty.
} 
matemáticos, e que encontram aplicações em várias áreas do conhecimento ${ }^{57}$. Também têm sido utilizadas para avaliação estratégica e de impactos sócio-econômicos.

Especificamente na área de planejamento de transportes, destacam-se os trabalhos de Lisboa, Palhares e Martins ${ }^{58}$ que vêm utilizando modelos multicriteriais para avaliação de alternativas de traçado de rodovias e de sistemas de transporte de massa. Palhares e Martins tratam especificamente do corredor Rio de Janeiro - Niterói - São Gonçalo - Itaboraí para a implantação do sistema metroviário.

De maneira geral, inicia-se com uma estruturação hierárquica de objetivos, critérios/indicadores, e alternativas consideradas no estudo. Procede-se a comparações entre pares de critérios/indicadores, quanto à importância de cada critério/indicador em relação ao objetivo do trabalho, estabelecendo matrizes de comparação paritárias. No caso da AHP, através da técnica do autovetor, calcula-se os pesos locais e globais para cada critério/indicador nos vários níveis hierárquicos e em relação às alternativas em estudo. Assim, torna-se possível estabelecer uma ordenação das alternativas e decidir pela escolha da mais adequada no contexto analisado, resultando num importante elemento do processo de decisão.

\footnotetext{
${ }^{57}$ Destacam-se os trabalhos de Carlos Bana e Costa, Jean-Claude Vansnick, Jean-Marie De Corte que dirigem centros de pesquisa que trabalham com MMAD - Modelos Multicritérios de Análise de Decisão na Inglaterra, Portugal e Bélgica respectivamente. Bana e Costa, em especial, mantém um forte relação com o Brasil para a aplicação desses modelos, em parceria com universidades em Santa Catarina, São Paulo e Rio Grande do Norte, dentre outras.

58 Ver descrição de LISBOA, M. V. Aplicação do Método de Análise Hierárquica - MAH para o Auxílio à Tomada de Decisão em Estudos de Alternativas de Traçado de Rodovias. Disponível em <http://www.guiadelogistica.com.br> Acesso em 15 jun. 2005.e PALHARES, G. L.; MARTINS, J.A. Avaliação de Alternativas de Transporte do Corredor Rio de Janeiro - Niterói - São Gonçalo - Itaboraí: o Método da Análise Hierárquica Multicriterial. In: Anais do XIV Congresso da Associação Nacional de Pesquisa e Ensino em Transportes, 2000, Gramado, RS. Panorama Nacional da Pesquisa em Transportes 2000. Rio de Janeiro: ANPET, 2000. p. 411-422.
} 
O passo mais importante nas técnicas de Análise Multicriterial é a escolha dos fatores relevantes para a decisão. E isso se faz a partir da análise de experiências anteriores, quando se seleciona quais foram os aspectos mais significativos. Daí resultam os critérios/indicadores que deverão ser utilizados na situação em pauta.

Especialistas e setores da sociedade diretamente afetados pela possível decisão são chamados a opinar sobre a importância dos critérios/indicadores estabelecidos para cada alternativa, e ainda sobre o grau de intensidade dessa importância. São feitas a seguir, verificações de consistência das respostas encontradas. Os dados são tabulados e processados através de programa de computação específico. O principal mérito de se adotar um modelo de auxílio à decisão é que as análises multidisciplinares podem ser realizadas em uma base quantitativa documentada.

Alguns autores, como Schimdt ${ }^{59}$, destacam que as análises multicriteriais surgiram enquanto crítica ao modelo racional da Teoria da Decisão, na qual um único agente decide baseado na informação perfeita. Têm como princípio que a experiência e o conhecimento das pessoas é pelo menos tão valioso quanto os dados utilizados para a tomada de decisão. Segundo Antão da Silva et al. $^{60}$, essas análises permitem a inclusão de diferentes pontos de vista de interessados e atores, sugerindo uma ordenação de alternativas, como bases para futuros

\footnotetext{
${ }^{59}$ SCHIMDT, A. M. A. Processo de Apoio à Tomada de Decisão: abordagens AHP e MacBeth. Dissertação apresentada para obtenção do título de Mestre em Engenharia, Universidade Federal de Santa Catarina, Florianópolis, 1995. Disponível em: <http://www.eps.ufsc.br/disserta/angela/indice/index.htlm> Acesso em 08 ago. 2008.
}

${ }^{60}$ ANTÃO da SILVA, P.; BANA e COSTA, C.; NUNES CORREIA, F. Avaliação Multicritério das Incidências Ambientais de Medidas de Controlo de Cheias: o Caso da Ribeira do Livramento. [17 p.] Disponível em: <http://www.aprh.pt/cpngressoagua98/files/com/106.pdf> Acesso em: 26 jan. 2008. 
acordos e compromissos. Cintia de Lima Vilas Boas ${ }^{61}$ no seu texto sobre análise da aplicação de MMAD - Modelos Multicritérios de Análise de Decisão acrescenta e conclui que:

Esses métodos, contudo, não visam apresentar uma solução ao problema, elegendo uma única verdade representada pela ação selecionada. Na realidade elas buscam apoiar o processo decisório através da recomendação de ações ou cursos de ações a quem vai tomar decisão.

[...] é importante que os gestores públicos sejam munidos de instrumentos de análise econômica que facilitem o processo de tomada de decisão. Estes instrumentos devem se constituir em abordagens mais flexíveis que também permitam a agregação de variáveis intangíveis monetariamente e a consulta às populações afetadas.

As abordagens multicritérios proporcionam uma melhor adaptação aos contextos decisórios encontrados na prática. Elas permitem que um grande número de dados, interações e objetivos sejam avaliados de forma integrada.

[...] dão ao processo de tomada de decisão clareza e transparência.

[...] são as abordagens mais desenvolvidas e exploradas científicamente [...]

Outro caminho de auxílio à decisão, muito mais sofisticado do ponto de vista matemático e em franco desenvolvimento e utilização para a análise de sistemas complexos, são os métodos de Redes Neurais Artificiais ${ }^{62}$. Trata-se de um conceito de computação que visa trabalhar no processamento de dados de maneira semelhante ao desempenho do cérebro humano. Diferentemente dos sistemas computacionais convencionais, não está baseada em regras ou programas pré-estabelecidos.

A propriedade mais importante das redes neurais é a habilidade de aprender de seu ambiente e, como no cérebro humano, o procedimento usual na solução de problemas passa inicialmente por uma fase de aprendizagem, onde um conjunto de exemplos é apresentado para a rede, que extrai automaticamente as características necessárias para representar a informação fornecida. O aprendizado ocorre quando a rede neural atinge uma solução generalizada para uma classe de problemas, filtrando e eliminando os elementos que não interessam. Essas características são usadas posteriormente para gerar respostas para o novo problema proposto.

\footnotetext{
${ }^{61}$ VILAS BOAS, C. de L. Análise da Aplicação de Métodos Multicritérios de Apoio à Decisão (MMAD) na Gestão de Recursos Hídricos. Disponível em: <http://www.cprm.gov.br/rehi/simposio/go> Acesso em: 26 maio 2008.
}

62 TATIBANA, C. Y.; KAETSU D. Y. Homepage de Redes Neurais. Disponível em <http://www.din.uem.br/ia/neurais> Acesso em: 03 jul. 2005. 
É uma forma para se lidar com problemas muito complexos, de várias naturezas, com diferentes graus de importância, apresentando grande capacidade de generalização e de adaptação no espaço e no tempo. Através de nós - os neurônios -, que se relacionam entre si através de pesos diferenciados - sinapses - e com funções (algoritmos) que vão sendo estabelecidas através da fase de aprendizado, simula-se o comportamento do cérebro humano.

Finalmente, e com grandes perspectivas de utilização como ferramenta para o processo de decisão em assuntos de grande complexidade e capaz de tratar com um grande número de variáveis - na maioria das vezes de naturezas diferentes -, observa-se o desenvolvimento de outras lógicas não clássicas, que se dispõem a enfrentar elementos considerados aleatórios, não cartesianos, como a Lógica dos Sistemas Nebulosos (Lógica Fuzzy) ${ }^{63}$ e a Lógica Paraconsistente $^{64}$. Trata-se das técnicas mais avançadas no desenvolvimento de um pensamento que permite a ponderação de alternativas e que possibilita a consideração de proposições de uma forma mais próxima do funcionamento do cérebro humano, introduzindo incertezas e a quantificação das mesmas e reconhecendo o conceito de contradição da lógica aristotélica.

Os processos de computação tradicional trabalham como respostas sim e não, não estando incluída a possibilidade de uma avaliação de graus de certezas e de incertezas quanto aos fatores analisados, de forma numérica. Na Lógica Paraconsistente é possível avaliar qual o grau de crença/verdade de um fenômeno que não necessariamente é o oposto do grau de descrença/falso. Uma proposição pode ter um grau de crença de $70 \%$, mas um grau de descrença de 50\%, a partir da lógica particular de cada entrevistado.

\footnotetext{
${ }^{63}$ COX, E. Fuzzy Fundamentals. EUA: IEEE Spectrum, 1992.

${ }^{64}$ COSTA, N. da; ABE, J. M., SILVA FILHO; J. I.; MUROLO, A. C.; LEITE, C. F. S. Lógica Paraconsistente Aplicada. São Paulo: Editora Atlas, 1999. 214 p.e SILVA FILHO, J. I.; ABE, J. M. Introdução à Lógica

Paraconsistente Anotada com Ilustrações. Santos: Editora Emmy, 2000. 166 p.
} 
Da mesma forma que na Análise Multicriterial, é necessária a realização de entrevistas com especialistas e/ou com setores da sociedade interessados no assunto analisado, de forma que os graus de crença e de descrença possam ser aferidos e será a somatória ponderada dessas respostas que se constituirá na resposta à proposição apresentada.

Sua utilização em problemas complexos vem crescendo, em especial por possibilitar o tratamento de um grande número de variáveis, de naturezas diversas, não necessariamente transformáveis em indicadores mensuráveis, mas cujas observações quantitativas podem ser transformadas em valores relativos à crença e descrença em uma determinada proposição. Vem sendo proposta em trabalhos de planejamento, pois permite considerar contradições, indefinições, inconsistências e indeterminações, características reais do fenômeno urbano e que desta forma, podem ser enfrentadas e apresentadas como elementos para a decisão.

\subsection{Contexto político-institucional brasileiro para as decisões relativas a empreendimentos estruturais de desenvolvimento urbano ${ }^{65}$}

No século XX, o Brasil foi palco de grandes mudanças institucionais e de gestão com a transformação de um Estado predominantemente patrimonial em um Estado gerencial em formação, passando pelo Estado burocrático, segundo Bresser-Pereira. Essas mudanças não ocorreram de forma gradativa, sendo, como em vários países, decorrentes de severas reformas institucionais. Embora o caminho percorrido efetivamente tenha levado a mudanças significativas, persistem no momento atual da administração pública, em todos os níveis de governo, traços de comportamentos fortemente burocráticos e de grande formalidade

\footnotetext{
${ }^{65}$ Esta seção está fortemente baseada nos textos de Luis Carlos Bresser-Pereira, citados na bibliografia, relativos à sua visão do caminho trilhado pelo Brasil da passagem de um Estado patrimonial a um Estado gerencial, passando pelo Estado burocrático e pela sua concepção da Reforma Gerencial do Estado.
} 
processual, bem como de comportamentos elitistas e de baixa representatividade dos governantes, característicos do Estado patrimonial. A forma como a administração pública está organizada e os grupos sociais que a sustentam condicionam as decisões gerais de governo, desde a escolha dos projetos a serem realizados até a forma de implementação dos mesmos.

Em linhas gerais, no início do século XX, o Estado patrimonial brasileiro, de características autoritárias, era sustentado por uma sociedade senhorial recém saída do escravismo, baseada numa economia agrícola mercantil, pré-capitalista, que perdurou durante o Império e que esteve presente durante todo o período da primeira república. De caráter não intervencionista, o Estado pouco atuou na produção e restringiu-se à concessão de empréstimos ou garantias de retorno à iniciativa privada que quisesse investir. É o caso das empresas estrangeiras que atuaram no setor ferroviário e ainda de empresas multi-utilities, como a Light, que atuaram no Rio de Janeiro e em São Paulo no início desse século, antecipando uma tendência recente de atuação de uma mesma empresa em vários setores da infra-estrutura urbana.

Segundo Bresser-Pereira, embora agisse em nome do Estado, a administração patrimonialista não podia ser considerada como administração pública, uma vez que não distinguia claramente o bem público do bem privado e não tinha como principal objetivo o interesse público. As decisões eram tomadas por um pequeno grupo aristocrático-burocrático de juristas, letrados e militares, ligado às elites dominantes por laços de toda a ordem - família e compadrio, por exemplo - e mantido pelo excedente econômico do próprio Estado. O emprego público, praticamente sem função, estava baseado, no caso do corpo de juristas, principalmente na capacidade de lidar com os conflitos entre grupos dominantes dentro das normas constitucionais e constituiu-se no cerne da estabilidade do sistema imperial e posteriormente da $1^{\mathrm{a}}$. República. 
Os critérios de escolha desses funcionários não eram racionais nem baseados em normas legais e construíram um complexo sistema de agregados e clientes sustentado pelo Estado, confundindo o patrimônio público com o privado. Essa nova classe média em formação ${ }^{66}$ detinha um enorme poder político. Conseqüentemente, suas decisões refletiam os interesses pessoais predominantes - o comportamento clientelista -, onde a racionalidade do planejamento inexistia. Jorge Gustavo da $\operatorname{Costa}^{67}$ aponta sete planos nacionais de interesse no século XIX, entre 1869 e 1882, todos voltados para a questão dos transportes ${ }^{68}$.

No entanto, é parte dessa burocracia patrimonialista, a classe dos militares, que, em nome de uma abstrata racionalidade, produziu as revoluções que levaram às novas fases de descentralização do Estado. A política dos governadores e das oligarquias locais perdurou até 1930 - governadores com poderes significativos em relação à União e poucos poderes com relação aos coronéis locais - mas, com a insatisfação crescente dos militares, chegou-se ao Estado autoritário do primeiro governo Vargas.

A primeira era Vargas, 1930 a 1945, ensejou grandes transformações, tanto na organização da sociedade como nos rumos do desenvolvimento econômico, e conseguiu estabelecer o poder sobre os estados federados, dando impulso ao processo de industrialização, ao iniciar suas

\footnotetext{
${ }^{66}$ Ver DA MATTA, R. Considerações Sócio-Antropológicas sobre a Ética na Sociedade Brasileira. informe apresentado ao Banco Interamericano de Desenvolvimento, nov. 2001, [16 p.]. Disponível em: $<$ http://www.codigodeetica.es.gov.br/artigos > . Acesso em 25 ago. 2008. Na parte inicial, o autor discorre sobre a noção de serviço público e cita o trabalho de Sérgio Miceli - “Intelectuais à Brasileira”, Cia. das Letras, São Paulo, 2001, como um aprofundamento da questão.

${ }^{67}$ COSTA, J. G. Planejamento Governamental - a experiência brasileira. Fundação Getúlio Vargas, 1971.569 p. Ver também, PAULA, D. A. Ferrovias x Rodovias: Agentes e Agências na Construção de Projetos Nacionais de Transportes (1920-1954). Universidade Federal de Uberlândia. [11 p.] Disponível em: <http://www.r].anpuh.org/Anais/2002/Comunicacoes> Acesso em: 15 nov. 2008.

${ }^{68}$ Esses planos levaram o nome de seus idealizadores: o primeiro em 1838, de autoria do Conselheiro José Silvestre Rabelo; 1869, do engenheiro militar José de Moraes; de 1874 e 1882, do engenheiro Ramos de Queiroz; de 1874, do engenheiro André Rebouças; de 1881, do engenheiro Honório Bicalho e em 1882, o de A. de Oliveira Bulhões.
} 
ações de Estado promotor do desenvolvimento. Iniciou-se a reforma burocrática, sob um regime autoritário e modernizador. Começou a se formar uma burguesia industrial ${ }^{69}$ e uma nova classe média tecno-burocrática, cuja função era a coordenação das ações das grandes empresas produtoras de bens e de serviços, fossem elas estatais ou privadas, valorizando a competência técnica. Teve início a revolução modernizadora ${ }^{70}$.

Do ponto de vista da administração pública, foi idealizada a Reforma Burocrática de 1936 que introduzia uma racionalização de procedimentos, estabelecendo bases para uma administração profissional em contraposição aos métodos da administração patrimonialista e que tinha como objetivo formular e coordenar ações de planejamento setorial. Criava um serviço público lastreado em normas para ingresso - dentre elas o concurso público -, classificação de cargos, organização de serviços de pessoal, aperfeiçoamento sistemático, administração orçamentária, padronização de compras pelo Estado e racionalização geral de métodos. Foram criados os primeiros órgãos reguladores nas áreas econômica e social - conselhos, comissões e institutos. Entre 1930 e 1950, houve a criação de um pequeno grupo de empresas estatais ${ }^{71}$, que se constituiu no núcleo do desenvolvimento industrial inicial do modelo de substituição de importações. Tiveram início práticas de planejamento concebidas na forma de documentos de planejamento orientadores da ação do Estado para todas as áreas ${ }^{72}$, destacando-se o Plano

\footnotetext{
${ }^{69}$ Diferentemente de outros países, a sociedade senhorial brasileira não se transformou em uma sociedade capitalista clássica - de burgueses e trabalhadores -, mas criou a administração pública burocrática - serviço social profissional, no domínio da racionalidade com normas e procedimentos rígidos e universais.

${ }^{70}$ Em outros países essa revolução modernizadora teve início ainda no século XIX e foi lastreada por regimes democráticos. Diferentemente no Brasil, a revolução de 1930 introduziu um regime autoritário com fortes traços populistas.

${ }^{71}$ Em 1942 foi criada a Companhia Vale do Rio Doce e em 1943, a Companhia Nacional de Álcalis e a Fábrica Nacional de Motores.

${ }^{72}$ Foram elaborados planos setoriais e na área de transportes, destacam-se: em 1934, Plano Geral de Viação Nacional e em 1944, o Plano Rodoviário Nacional.
} 
Especial (1939-1943), com o objetivo de criar indústrias, construir infra-estrutura e promover a defesa nacional.

No entanto, as reformas foram parciais e em vários setores existia uma clara desobediência aos princípios burocráticos. O Estado necessitava de uma burocracia profissionalizada, mas fazia concessões ao patrimonialismo, perseverando nas regras clientelistas. O resultado foi um formalismo demasiado em alguns setores, com grande discrepância entre as normas e a realidade das decisões e das ações.

As forças comprometidas com o desenvolvimento econômico viam no formalismo burocrático um descompasso com as necessidades do país, com o ritmo acelerado do progresso técnico em todas as áreas, como empecilho ao desenvolvimento. Durante o seu governo, o presidente Juscelino Kubitscheck implantou uma administração alicerçada em grupos de atuação setorial para fazer face às necessidades de agilidade da máquina administrativa ${ }^{73}$ e em seguida, o presidente João Goulart iniciou estudos para uma reforma mais consistente. No período de 20 anos, que vai do fim do Estado Novo até o período que se inicia com a Revolução Militar de 1964, destacam-se esforços de planejamento nacional: Plano de Obras e Equipamentos - POE (1944-1948), o Plano Salte (1950-1954), o plano da Comissão Mista Brasil-Estados Unidos (1950-1953), o Plano de Metas (1956-1960) e o Plano Trienal de Desenvolvimento Econômico e Social (1961-1963). Dentre eles, o Plano de Metas do governo de Juscelino Kubitscheck é o mais abrangente e com características de formulação clara de objetivos e metas em praticamente

\footnotetext{
73 Segundo LOW-BEER, J. O Estado e as Políticas públicas - Uma revisão histórica da atuação estatal no Brasil (1950 a 1997). Trabalho Programado 1, FAUUSP, mimeo, abr. 2000, 34 f.: “[...] pela primeira vez o Estado atuou diretamente na gestão das políticas de desenvolvimento, através dos "grupos executivos, compostos por representantes dos setores públicos e privados [...]” Observa-se um vislumbre de gestão gerencial, no entanto, na forma de grupos paralelos ao corpo burocrático existente.
} 
todas as áreas, destacando-se pela sua característica dinâmica de tentar implantar um processo contínuo de planejamento no nível federal.

Praticamente não existiam orientações específicas relativas aos transportes urbanos, nem nos planos gerais nem nos setoriais, mas datam desse período de 20 anos a gestação e implantação das políticas públicas que levaram à opção de desenvolvimento rodoviário para todo o país em detrimento do transporte sobre trilhos. Veremos mais adiante que nas cidades houveram disputas acirradas entre os tradicionais engenheiros ferroviaristas e os partidários dos automóveis e ônibus. Em especial no Rio de Janeiro, nesse período, muitas discussões se concentraram em torno da pertinência da manutenção do sistema sobre trilhos, sobre a necessidade de sua modernização - incluindo linhas subterrâneas de metrô - e ainda sobre o abandono e gradual obsolescência desse sistema, como aconteceu com os bondes.

Conforme observa Bresser-Pereira e outros autores, pode-se considerar que o período de 1945 a 1964 foi a primeira experiência brasileira de um regime que se pode chamar de democracia, entretanto na forma de uma democracia de elites. O golpe militar de 1964 pôs fim à nascente democracia, estabelecendo novamente um regime autoritário, também modernizador e de caráter burocrático-capitalista, que durou 20 anos. Foi o resultado da aliança da moderna burocracia civil e militar com as classes médias burocráticas do setor privado e com a burguesia que passava a ser uma classe capitalista diversificada e complexa.

Do ponto de vista da administração pública, foi o Decreto-Lei no. 200 de 25/02/1967 ${ }^{74}$, que veio a estabelecer novos parâmetros modernizadores para o comportamento burocrático. Procurou substituir a administração pública burocrática por uma “administração para o

\footnotetext{
${ }^{74}$ BRASIL. Decreto-Lei no. 200, de 25/02/1967, que dispõe sobre a Organização da Administração Federal,
} estabelece Diretrizes para a Reforma Administrativa e dá outras Providências. 
desenvolvimento”. Basicamente, esse instrumento legal distinguiu a administração direta e indireta e definiu seu desenho, estabeleceu a autonomia de gestão das autarquias, fundações e estatais, fortaleceu o sistema de mérito e reduziu a burocracia para as compras do Estado. As ações decorrentes, no entanto, apresentaram um duplo resultado: de um lado, ensejaram uma descentralização administrativa, permitindo uma maior autonomia para o agente público e por outro lado, o poder político voltou a se concentrar ainda mais nas mãos da União, em detrimento das unidades federativas.

O grande projeto de industrialização, baseado em grandes empresas estatais, passou a ser viável, assim como a desconcentração espacial e administrativa dos serviços públicos e da infra-estrutura do país, através de empresas públicas e de economia mista, muitas das quais já existiam desde o início da reforma burocrática, ou foram sendo criadas ao longo desses 30 anos, tais como, inicialmente, a CSN e em seguida, a Petrobrás, a Eletrobrás, a Telebrás, o BNDE, o $\mathrm{BNH}^{75}$ e agências reguladoras como o Banco Central. Sucederam-se os anos do milagre brasileiro, de grande dinamismo econômico, com pesados investimentos públicos em infra-estrutura ${ }^{76}$ - energia, transportes e comunicações -, e nos setores de petróleo, químico e siderúrgico. Adicionalmente, o governo promoveu o financiamento da construção

\footnotetext{
${ }^{75}$ Com a criação do BNH em 1968, foi instituído o SFH, Sistema Financeiro da Habitação e o SFS - Sistema Financeiro do Saneamento, ambos responsáveis pelo forte impulso na construção civil e pela grande expansão da implantação e dos serviços de água e esgoto.

${ }^{76}$ Ainda segundo Low-Beer, datam da segunda metade da década de 1970 projetos de grande porte tais como: Expansão da Petrobrás - polos de Camaçari, Paulínea e Duque de Caxias; Programa de Expansão Siderúrgica - abrangendo Volta Redonda (RJ) e Cosipa (SP); Ferrovia do Aço - ligação ferroviária para transporte de minério de ferro de Minas Gerais para o Porto de Tubarão, em Vitória; Projeto Carajás - grande empreendimento minerador, situado no Pará; UHE Tucuruí - que contribuiu para viabilizar a nova região mineradora no norte do país; UHE Itaipú (em associação com o governo paraguaio); Barragem de Sobradinho no Vale do São Francisco - para fins de geração de energia elétrica, captação de água e irrigação; Portos de Itaqui (Maranhão) e Barcarena (Pará); Pavimentação da Rodovia Belém-Brasília - para integração regional e de mercados; Rodovia dos Imigrantes - via expressa ligando São Paulo ao Porto de Santos; Corredores de Exportação - melhorias e ampliações na infra-estrutura portuária - marítima e aérea - abrangendo o retroporto de conteiners de Conceiçãozinha, o Porto de Santos (SP), construção dos aeroportos de Cumbica (SP) e do Galeão (RJ) e programa de melhoria das ligações viárias com os portos, para melhorar o escoamento da produção; EMBRATEL - montagem da rede de transmissores de micro-ondas que dão origem à expansão da Rede Globo pelo país. Anteriores a estes, foram a construção de parte da rodovia Transamazônica e trechos da CuiabáSantarém.
} 
civil, privilegiando as faixas mais altas da classe média, um dos segmentos essenciais para a expansão econômica, que possibilitou um enorme giro de capital.

Houve uma centralização no campo tributário em 1969, com a alteração na distribuição de recursos nas três esferas de governo. Com a redução do Fundo de Participação dos Municípios e Estados e com a diminuição da autonomia dos mesmos para tributar, esses entes federados enfraqueceram-se politicamente.

No que se refere ao fortalecimento dos funcionários públicos, a reforma de 1967 ficou restrita aos escalões inferiores e não proporcionou o desenvolvimento de carreira nos escalões superiores. Estes continuaram a ser preenchidos a critério da Presidência da República, com recrutamento através das estatais. Persistiram as práticas clientelistas, cessou a realização de concursos públicos e pouco se aperfeiçoou a administração direta.

O D-L 200/1967 foi um prenúncio da reforma gerencial do Estado, que ocorreria no mundo a partir dos anos 1980 e no Brasil a partir de meados dos anos 1990, numa tentativa de superar a rigidez burocrática implantada e de adaptar as administrações para a economia globalizada. Nos anos imediatamente anteriores à redemocratização, o governo federal lançou o Programa Nacional de Desburocratização ${ }^{77}$ baseado no princípio da administração pública voltada para o cidadão como o destinatário de toda ação do Estado.

A reforma propiciada pelo D-L 200/1967 foi abandonada a partir da redemocratização do país em 1985, embora tenha se constituído numa transição inicial para a reforma gerencial. Formou-se uma burocracia pública de alta qualidade, sendo os novos administradores

\footnotetext{
${ }^{77}$ Concebido por Hélio Beltrão, também autor do D-L 200/67.
} 
principalmente engenheiros e economistas que nada tinham a ver com o sistema burocrático de carreiras rígidas da reforma de $1936^{78}$.

Nesse período, o planejamento e as decisões eram fortemente centralizados pela União, no seu mais alto escalão, embora as empresas estatais tivessem autonomia de gestão. As decisões relativas ao grande conjunto de obras de infra-estrutura (especialmente energia, transportes e comunicações), de habitação e de extensão dos serviços públicos, bem como as decisões estratégicas para viabilizar o modelo econômico desenvolvimentista, dentre elas aquelas relativas ao incentivo às exportações, ao reforço da indústria de base e ao endividamento externo, eram decisões do governo federal - ministérios e Presidência da República, lastreadas em vários planos de desenvolvimento. Destacam-se: o Plano de Ação Econômica do Governo - PAEG (1964-1966), o Plano Estratégico de Desenvolvimento - PED (19681970) e os dois Planos Nacionais de Desenvolvimento - I PND (1972-1974) e II PND (19751979). Todos eles tratam de proposições dirigidas ao combate à inflação, à aceleração do desenvolvimento econômico, à geração de emprego, à diminuição das disparidades regionais e à construção de uma política comercial internacional. Todos tiveram abrangência nacional e formularam diretrizes gerais para todo o território e específicas para cada região do país. Setorialmente, os PNDs trataram fortemente da expansão da infra-estrutura - energia, transporte, comunicações - e do desenvolvimento industrial, que consumiram mais da metade dos recursos. O II PND trouxe uma inovação, que já se desenhava no I PND, ao introduzir um capítulo bastante detalhado especialmente dirigido às estratégias de desenvolvimento urbano. O governo federal passou a ditar regras para a gestão territorial no nível municipal, aí inseridas as políticas para os transportes urbanos.

\footnotetext{
${ }^{78}$ A condução da política econômica em grande parte do período militar esteve sob a responsabilidade do economista Antonio Delfim Netto, para quem o planejamento era o instrumento básico para a decisão.
} 
Com relação às práticas de planejamento de âmbito nacional com relação aos transportes cabe acrescentar que, até 1975, o interesse nacional esteve voltado para os transportes intermunicipais e de carga e que, dentro dessa visão, houve uma grande coerência de política pública em todo o período que vai dos anos 1950 até o final dos anos 1980, independentemente dos traços políticos dos governantes. A política de transportes foi concebida para o desenvolvimento do setor rodoviário - da indústria automobilística, da construção de estradas e da produção de combustíveis - através de mecanismos tributários e de incentivos muito bem articulados de modo que, através de impostos sobre combustíveis e da fixação de preços dos mesmos, foi possível o auto-financiamento do setor ${ }^{79}$. Darbèra e Prud'Homme afirmam que uma pequena parte dos impostos sobre combustíveis serviu também para implementar o transporte ferroviário urbano - embora as realizações tenham sido inexpressivas -, aí inclusos os avais para financiamentos externos e os aportes financeiros diretos feitos aos sistemas metroviários de São Paulo e do Rio de Janeiro.

Nos anos 1980, o modelo desenvolvimentista conduzido pelo governo federal entrou em crise e a economia do país passou a apresentar baixas taxas de crescimento, redução do fluxo de capitais externos, progressivo esgotamento da capacidade de financiamento do Estado redução dos investimentos em infra-estrutura e em programas sociais -, evidenciando o esgotamento da estratégia de substituição de importações. Houve aumento da inflação e altos índices de desemprego.

Com a redemocratização e com uma reorientação da sociedade no sentido de substituir o conceito de nacionalismo, estabeleceu-se a necessidade de definição de uma nova estratégia e a determinação de novas funções para o Estado, nos campos econômico e tecnológico,

\footnotetext{
${ }^{79}$ DARBÈRA, R.; PRUD’HOMME, R. Transports Urbains et Développement Économique Du Brésil. Paris: Econômica, 1983. 166 p. Segundo esses autores, essa política foi concebida de forma totalmente independente de influências de pensamento de outros países.
} 
incorporando as áreas sociais e do meio ambiente, com vistas à maior competitividade internacional. Iniciou-se também uma busca de austeridade no tocante ao gasto público.

As administrações que sucederam o poder militar começaram a introduzir reformas estruturais com o intuito de retomar o crescimento econômico, como o início da privatização de empresas estatais, a abertura comercial externa e das importações, ampla reforma administrativa com demissão ou disponibilização de servidores públicos. O início da década de 1990 apresentava porém um país com infra-estrutura deteriorada: os sistemas rodoviário e de telecomunicações sucateados, colapsos no fornecimento de energia elétrica e no saneamento, resultado dos baixos investimentos públicos na década de 1980.

O presidente Fernando Henrique Cardoso deu continuidade às medidas de estabilização da economia, com a inversão de tendências, inaugurando um período de crescimento. Nesse período foi retomado com mais vigor o programa de privatizações ${ }^{80}$, iniciado no final da década de 1980. Foram postas em prática várias ações com o intuito de reduzir as restrições ao capital estrangeiro, eliminar os monopólios estatais e de desestatização da economia. Recuperou-se o discurso e a prática social, e foram privilegiados os programas que objetivassem a inserção produtiva e que levassem à descentralização de poder e de recursos, incluindo também a ampliação das instâncias de participação popular e do setor privado enquanto parceiros. Acrescentou-se à agenda social tradicional os aspectos relativos à Geração de Trabalho e Renda e das Condições Ambientais e Sanitárias. O Estado passou a

\footnotetext{
${ }^{80}$ Em julho de 1995 iniciou-se a privatização do setor elétrico, com a venda da Escelsa. Em seguida foi a vez das ferrovias e das telecomunicações e telefonia. Unidades siderúrgicas, petroquímicas e de fertilizantes já tinham sido privatizadas no início da década de 1990, a partir da Lei Federal 8.013/1990 que instituiu o Programa Nacional de Desestatização. Ver página 30 de LOW-BEER, J. D. O Novo Paradigma das Políticas Públicas Urbanas: A regulação dos Serviços Públicos - Limites e Alcances. Tese de Doutorado apresentada à Faculdade de Arquitetura e Urbanismo da Universidade de São Paulo, FAUUSP, 2000, mimeo, 108 p.
} 
atuar predominantemente nas faixas da população mais pobre, deixando ao mercado o atendimento da população socialmente mais integrada.

A descentralização política surgiu como uma demanda da nova sociedade civil, recém surgida no país, e governadores e prefeitos despontam como novos atores políticos relevantes. No entanto, a Constituição de 1988, baseada em princípios burocráticos clássicos, voltou a centralizar e a concentrar a administração pública, limitando a autonomia das agências e empresas do Estado, num modelo ultrapassado e incapaz de acompanhar os rumos da economia mundial ao qual o país iria forçosamente se integrar, como afirma Bresser-Pereira ${ }^{81}$. Ele afirma também que esse período de 10 anos que antecedeu a Reforma Gerencial de 1995 pode ser chamado de retrocesso burocrático, ao engessar o Estado numa orientação contrária ao D-L $200^{82}$. Na realidade, a reforma de 1967 havia se constituído em um avanço pioneiro. De maneira geral, persistia no país uma visão de desprestígio da administração pública.

Sucederam-se algumas ações no sentido de fortalecer a administração pública, dentre elas, a criação da ENAP - Escola Nacional de Administração Pública e a criação da carreira de

\footnotetext{
${ }^{81}$ Bresser-Pereira demonstra o retrocesso burocrático de 1988 ao apontar vários fatos relevantes, dentre eles a extinção do DASP em 1986, sucedido pela SEDAP - Secretaria de Administração Pública da Presidência da República, que seria extinta em 1989, sendo incorporada à Secretaria de Planejamento da Presidência da República, criação da SAF - Secretaria da Administração Federal, que teve curta duração e foi incorporada ao Ministério do Trabalho. Em resumo, a administração federal no período não teve clareza sobre os rumos que a prática burocrática deveria tomar. Nas palavras de Bresser-Pereira: [...] o retrocesso burocrático ocorrido no país entre 1985 e 1989 foi uma reação ao clientelismo que dominou o país naqueles anos, mas também foi uma afirmação de privilégios corporativos e patrimonialistas incompatíveis com o ethos burocrático [...] e [...] O resultado foi o desprestígio da administração pública brasileira [...] No entanto, a Constituição de 1988 reafirmou de maneira incontestável os princípios federativos, reforçando o papel dos entes federativos o que levou, de forma incoerente com os princípios burocráticos clássicos nela expressos, a fortalecer os caminhos da descentralização.

${ }^{82}$ Muitos entendem que a desconcentração e a flexibilização da administração pública que o D-L 200 promoveu, contribuiu para a crise do Estado. No entanto, a crise foi resultado do esgotamento do modelo nacionaldesenvolvimentista, fortemente alicerçado no endividamento externo, e também da falta de visão de que era preciso abrir a economia e torná-la mais competitiva e reformar ainda mais drasticamente o Estado.
} 
gestores públicos (para altos administradores). No entanto, não existia ainda uma orientação de reforma administrativa que pudesse enfrentar as drásticas alterações econômicas mundiais.

Paulatinamente, começam a surgir os contornos de uma sociedade pós-industrial - do comércio, dos serviços e das comunicações -, constituída de camadas sociais cada vez mais definidas pelo nível de educação, de prestígio social e de ocupação de cargos na hierarquia das grandes organizações públicas e privadas. Esta condição passou a exigir a reconstrução do Estado em bases mais democráticas, antevendo as reformas econômicas de ajuste fiscal e de abertura da economia. Foi assim aberto o caminho para a formação de um Estado gerencial, que deveria ser mais eficiente principalmente em função da competição internacional numa economia globalizada.

A Reforma Gerencial do Estado, empreendida em vários países, visa modernizar o Estado, o que tornaria a administração pública mais eficiente e voltada para o cidadão-cliente. Ela pressupõe a existência de um regime democrático da sociedade civil, mais avançado do que uma democracia de elites, em que a opinião pública tem importância crescente, como condição de funcionamento de uma sociedade pós-industrial. Em vários países do mundo essa reforma levou primeiramente à criação de um Estado mínimo, para, em seguida, reconstruir ou reformar o Estado.

No Brasil, essa reforma se iniciou formalmente em $1995^{83}$, com grande força política, partindo do princípio da inviabilidade de um Estado mínimo, mas reconhecendo a necessidade de ação reguladora do Estado. Seu principal objetivo é eliminar definitivamente o

\footnotetext{
${ }^{83}$ A reforma gerencial constituiu-se na principal tarefa do MARE - Ministério da Administração Federal e Reforma do Estado, criado em 1995, a partir da Secretaria da Administração Federal da Presidência da República. A reforma foi promulgada em 1998 através do Plano Diretor da Reforma do Aparelho do Estado.
} 
patrimonialismo, presente até hoje na forma de clientelismo ou de fisiologismo e ainda contribuir para uma mudança de cultura, da burocrática para a gerencial. Pressupõe que a melhor forma de combater o clientelismo é ser gerencial, “[...] dando autonomia ao administrador, valorizando-o por sua capacidade de decisão, inclusive de caráter político, ao invés de submetê-lo a um controle burocrático vexatório.”84

Busca criar novas instituições legais e organizacionais que permitam que uma burocracia profissional e moderna tenha condições de gerir o Estado brasileiro. Não se trata de substituir o Estado pelo mercado, mas reconstruí-lo e fortalecê-lo.

A reforma define com clareza as atividades exclusivas de Estado e as não-exclusivas e propõe o respectivo desenho institucional. As atividades exclusivas do Estado - definição de políticas, planejamento, decisões estratégicas - são exercidas pelo núcleo estratégico e as agências executivas ou reguladoras. As atividades não-exclusivas - serviços de natureza pública (sociais, educacionais e de natureza científica), financiados ou não pelo Estado ${ }^{85}$ e supervisionados através de contratos de gestão - são exercidas por organizações sociais instituições híbridas entre o Estado e a sociedade (públicas não-estatais). A reforma classifica ainda um grupo de atividades não-exclusivas que, pela sua natureza competitiva, devem ser exercidas pelo mercado - setores de bens e serviços.

\footnotetext{
${ }^{84}$ Em BRESSER-PEREIRA, L. C. A Reforma Gerencial do Estado de 1995. Revista de Administração Pública no. 3, 34 (4), p. 55-72, jul. 2000, página 65.

${ }^{85}$ As Organizações Sociais podem receber dotação orçamentária.
} 
De grande importância e no âmago das atividades exclusivas estão as agências reguladoras ${ }^{86}$ que são entidades com autonomia para regulamentar os setores empresariais - controle e fiscalização ${ }^{87}$ - que operem em mercados não suficientemente competitivos, reforçando a idéia do Estado regulador, abandonando a condição de Estado empresário. O núcleo estratégico controla as atividades das agências e das organizações sociais. A reforma fortalece o funcionário público e estabelece parâmetros para recrutar, selecionar e remunerar as carreiras do Estado.

As decisões, nesse modelo em implantação no Brasil, estão baseadas nos seguintes princípios: a gestão pela qualidade, a descentralização para os estados e municípios, a desconcentração ou delegação de autoridade para os dirigentes das agências estatais federais, estaduais e municipais. Obriga a definição de indicadores de desempenho para as organizações resultantes e a criação de mecanismos de controle social, em adição ao controle gerencial de resultados. O uso sistemático do planejamento estratégico ao nível de cada organização fica reforçado como principal elemento para a decisão.

A Reforma Gerencial do Estado no Brasil está apenas começando e a meta é a progressiva substituição de classes no comando político e administrativo por camadas/estratos sociais cujo

\footnotetext{
${ }^{86}$ Segundo MISSE. D. G. Agências Reguladoras - Muito mais do que Modismo. Prisma Jurídico, v.5, p. 277290. São Paulo, 2006., as agências reguladoras surgiram nos Estados Unidos na década de 1930, como instrumento independente - instituições da sociedade civil - para defesa da sociedade contra o modelo liberal clássico, então em crise. Tinham como objetivo a defesa dos cidadãos da exacerbação de certos direitos - direito à propriedade e à liberdade contratual -, buscando-se compensar as falhas do mercado. Reagan e Thatcher alteraram o sentido das agências - afastando-as da sociedade civil e aproximando-as do mercado e do Estado como garantia para a ampliação dos investimentos privados. Essas entidades começaram a perder seus poderes iniciais de intervenção em relação aos agentes privados, iniciando-se então um período de desregulação, conforme preconizado pelo Consenso de Washington, caracterizando o Estado neo-liberal. Têm proliferado no mundo como mais uma decorrência da globalização e como forma de garantia de manutenção dos contratos de concessão com as empresas privadas detentoras do direito de exploração dos serviços concedidos pelo Estado, de forma que o comprador tivesse garantias de contrato por parte dos governantes futuros. O termo agência é expressão simbólica da segurança requerida pelo sistema financeiro, como indicador de que esse Estado teria feito as reformas necessárias para ter acesso às linhas de crédito e ao capital internacional.
}

${ }^{87}$ A Constituição de 1937 já estabelecia que a regulamentação efetiva se fará nos casos de concessão dos serviços de utilidade pública - regulamentação contratual, por comissões ou diretamente pelo poder público. 
poder e renda sejam derivados do conhecimento técnico organizacional e que representem cada vez mais os interesses de todo o povo. O Estado burocrático-industrial e o Estado gerencial são estados de transição de uma política de elites para uma democracia moderna.

Alguns autores, como Ricardo Ismael e Roberto Da Matta, ao analisar os avanços empreendidos no governo Fernando Henrique Cardoso e ainda em curso, com relação ao fim das práticas patrimonialistas, afirmam que a reforma visou fortemente a redefinição do papel do Estado na economia e a redução dos gastos públicos - dando prioridade à diminuição do número de funcionários públicos e à contenção das despesas em geral - e que essas iniciativas são insuficientes para acabar com o sistema híbrido existente no Brasil, o qual faz conviver na administração pública princípios republicanos com práticas patrimonialistas. A modernização da administração pública no Brasil encontrou sempre resistências na cultura política predominante nas elites e do povo em geral. Conforme Da Matta ${ }^{88}$, o Brasil é um país onde o moderno e o tradicional convivem, trazendo reflexos no comportamento moral dos homens. $\mathrm{O}$ cotidiano brasileiro é marcado por uma ética dupla e a administração pública reproduz essa ética dupla. Existem instâncias no quadro administrativo brasileiro para lidar com a ética pública $^{89}$, embora ainda faltem ao cidadão comum meios para inibir, reprimir ou punir os desvios de conduta na administração pública.

\footnotetext{
${ }^{88}$ DA MATTA, R. Considerações Sócio-Antropológicas sobre a Ética na Sociedade Brasileira. informe apresentado ao Banco Interamericano de Desenvolvimento, nov. 2001, [16 p.]. Disponível em: $<$ http://www.codigodeetica.es.gov.br/artigos $>$. Acesso em 25 ago. 2008.

${ }^{89}$ Segundo pesquisa de ISMAEL, R. Do Estado Patrimonial ao Estado Pós-Burocrático: considerações sobre a defesa do Interesse Público. Departamento de Sociologia e Política, PUC-Rio de Janeiro, [9 p.], Disponível em <http://aol.universiabrasil.net/material/img/ilustr/2005/jun/anpuh.doc> Acesso em: 11 jun. 2008, existem vários órgãos do poder executivo que têm como finalidade principal a questão da ética pública: Comissões de Ética Pública (acompanha a observância do Código de Conduta da Alta Administração Federal); Comissões de Ética (tratam da ética do servidor no tratamento com as pessoas e com o patrimônio público); Corregedoria-Geral da União (defende o patrimônio público); Corregedorias Específicas - da Secretaria de Receita Federal, da Polícia Federal, da Advocacia da União, das Agências Nacionais Reguladoras. Existem ainda órgãos que têm a questão da ética pública entre suas atribuições: Secretaria de Recursos Humanos do Ministério do Planejamento, Secretaria Federal de Controle e Polícia Federal. Órgãos do poder legislativo que têm a questão da ética pública entre suas atribuições: Tribunal de Contas da União, Comissões Temáticas da Câmara dos Deputados e do Senado Federal e Comissões Parlamentares de Inquérito. No poder judiciário, destaca-se o Ministério Público.
} 
Da Matta acrescenta que a introdução do conceito de ética na administração pública reflete “[...] uma forte e irrevogável dimensão moral no âmbito da administração pública. Agora não se trata mais de multiplicar eficiência e recursos, mas de realizar isso dentro de certos limites e com uma certa atitude [...]"90, e que a criação da Comissão de Ética pelo governo Fernando Henrique Cardoso é um exemplo da tentativa de aproximação da ética do servidor à ética da pessoa e portanto de reduzir a presença da ética dupla da sociedade brasileira.

Assim, pode-se observar que o quadro administrativo nacional no qual se insere a decisão pela implantação do sistema metroviário da cidade do Rio de Janeiro era basicamente constituído por uma burocracia técnica em formação com um poder de decisão lastreado nas empresas estatais recém constituídas. Antecede os princípios da reforma gerencial do Estado que preconiza uma administração voltada para o cliente e suas decisões estiveram fortemente centralizadas na esfera nacional, sob a ótica do estado produtor de bens e serviços e estiveram primordialmente baseadas na capacidade de se ofertar um produto.

\footnotetext{
${ }^{90}$ DA MATTA, R., op. cited.
} 
CAPÍTULO 02 


\section{TIPOLOGIA DE ATORES PRESENTES NO PROCESSO DECISÓRIO}

\section{Modelo Explicativo e Hipóteses}

No estudo da lógica decisória, vários setores de intervenção pública podem motivar estudos de caso relevantes e que têm uma repercussão direta ou indireta no espaço urbano. Algumas atividades como educação, saúde e assistência social, por exemplo, revelam seu caráter predominantemente político de forma bastante explícita, expondo claramente valores e interesses de uma sociedade ou grupos sociais específicos, enquanto que em outras, o caráter técnico - baseado na melhor solução técnica suficientemente econômica - aparenta ser o aspecto predominante na prática da decisão: energia, transportes, saneamento etc. São estes últimos setores de atividades, que, muitas vezes, escondem seu caráter fundamentalmente político através de ações legitimadas por justificativas técnicas, que não deixam transparecer uma decisão negociada entre os participantes do processo. Nesses setores, podemos encontrar uma riqueza de situações a serem investigadas descortinando um complexo processo transacional entre os grupos sociais.

Em função do histórico do desenvolvimento das práticas de planejamento apresentado no capítulo anterior, pode-se afirmar que na análise dos processos decisórios relativos a empreendimentos estruturais de desenvolvimento urbano, permanecem ainda de grande atualidade os rumos metodológicos desenvolvidos nos anos 1980, que apontam para a compreensão dos interesses dos diversos atores, presentes na formulação de planos e nas decisões para sua implementação, considerando o espectro de sua racionalidade, mesmo que apresentem lógicas conflitantes. 
Assim, no meio urbano, métodos que permitam a identificação de atores, que possam ser reunidos em grupos que apresentem algum grau de semelhança em relação a seu papel na construção e usufruto do espaço urbano, tais como os grupos elencados segundo a lógica proposta por Castells ${ }^{1}$ em 1972 - Produção, Consumo, Gestão e demais -, dentro das esferas econômica, política e ideológica, podem auxiliar no entendimento da multiracionalidade dos mesmos e propor confirmações para hipóteses relativas a quem efetivamente decide num dado momento histórico-social.

No caso específico deste trabalho de tese, cabe adicionalmente contextualizar a decisão para a construção do Metrô-RJ que se dá numa fase política e econômica na qual o país reafirmou seu modelo de desenvolvimento baseado em forte intervenção governamental na economia, desta vez com múltiplos atores administrativos organizados, deixando à margem o aparelho burocrático existente.

Nesse período, o Estado agiu como o maior provedor monopolístico para a infra-estrutura e para alguns setores chave da indústria de base, numa opção desenvolvimentista predominante à época nas economias industriais mais avançadas. As decisões estiveram fortemente concentradas num grupo restrito no alto escalão do governo federal e também fortemente lastreadas nos conceitos de planejamento e no entendimento de que uma burocracia tecnicamente competente teria melhores condições para decidir e conduzir as questões mais

\footnotetext{
${ }^{1}$ Cabe lembrar que o modelo concebido por Castells como explicação para o espaço urbano - apresentado em $\boldsymbol{L a}$ Question Urbaine -, constituiu-se numa ferramenta de análise que representou uma ruptura na forma como a realidade urbana era analisada até então, ao introduzir elementos da teoria marxista ao mesmo tempo em que deduz ferramentas teóricas a partir de situações concretas, fazendo em seguida o movimento inverso de explicação da realidade. Em seguida, 1974, Castells aponta em Monopolville: l'entreprise, l'état, l'urbain novos caminhos teóricos de análise e explicação, uma vez que observava-se uma nova escala de desenvolvimento do capitalismo, acompanhada de suas contradições. Almeja compreender e explicar os processos de urbanização a partir do estudo de grande conglomerados industriais implantados na lógica do capital monopolista, atrelados ao funcionamento do Estado. Na linha de trabalhos emblemáticos, Castells novamente, já no final da década de 1990 (1996-1999) lança conhecimento sobre as questões da globalização, das redes de informação e a pulverização urbana em A Sociedade em Rede - A Era da Informação, Sociedade e Cultura.
} 
estratégicas do país. Certamente, nos dias de hoje, as decisões para a construção do Metrô-RJ passariam por discussões em instâncias descentralizadas - estado e município - e por um espectro maior de grupos de interesse organizados fora da esfera governamental.

Neste capítulo, são apresentadas hipóteses de atuação e comportamento dos vários grupos de interesse presentes na idealização e implementação da idéia de se construir um sistema de metrô no Rio de Janeiro. Para tanto, inicialmente são elencados os atores contemporâneos a esse processo decisório, de forma que a análise do mesmo possa se dar dentro do contexto sócio-econômico e político da época para que, em seguida, possam ser construídas as hipóteses de atuação dos mesmos.

Deve ser salientado que hoje, no início do século XXI, no momento atual de organização dos modos de produção na sociedade brasileira, estão presentes no mercado de produção de infraestrutura e de bens em geral um conjunto de atores muito mais amplo do que à época da decisão de se construir o sistema metroviário do Rio de Janeiro. Face às grandes alterações no modo de produção capitalista no mundo nas últimas décadas, fazem parte dos grupos de interesse grandes corporações - algumas nacionais, mas predominantemente multinacionais como é o caso nas áreas de telecomunicações, de informação, de energia, de exploração de recursos naturais e de saneamento, dentre outras, que não existiam naquele momento.

As decisões sobre a presença de empresas nacionais ou estrangeiras em alguns setores não estão hoje necessariamente ligadas ao domínio de tecnologia, mas sim à capacidade operacional de enfrentamento de um problema em condições que respondam aos consumidores e de acordo com os interesses do Estado. Questões como nacionalização e protecionismo, que foram centrais na segunda metade do século passado, não são discutidas 
da mesma forma que à época do tema principal deste trabalho de pesquisa, à exceção de alguns poucos setores considerados essencialmente estratégicos. Pode-se mesmo observar o movimento inverso, com empresas nacionais entrando agressivamente no mercado de vários países com o mesmo padrão de comportamento de negociação das empresas estrangeiras e multinacionais. Adicionalmente, percebe-se uma enorme fragmentação do processo produtivo - em tempo e local - com diferentes graus de protecionismo. O pensamento e a informação globalizada, muitas vezes de curta duração, influenciam as decisões de todos os grupos de interesse.

Pode-se, na atualidade, acrescentar aos grupos de interesse e atuação nas decisões, além dos produtores, consumidores e gestores - cujo comportamento está evidenciado neste trabalho -, o terceiro setor na forma de atuação das organizações não governamentais nacionais, estrangeiras ou multinacionais. Cabe ainda ressaltar que, em muitos países, o papel do Estado na produção física de materiais e serviços tem apresentado um ritmo de retração crescente, assumindo cada vez mais um papel de regulador, o que ainda não era o caso à época da intervenção estudada. Relativamente aos atores do setor privado, também existe um movimento inverso para que as empresas assumam uma parte do então papel do Estado, na forma de uma presença baseada no conceito de responsabilidade social e ambiental.

Assim, para auxiliar na compreensão das condições para a decisão quanto ao Metrô do Rio de Janeiro, em especial para a definição dos grupos de interesse e seus comportamentos, é importante considerar modelos de pensamento contemporâneos à intervenção analisada. 


\subsection{O Modelo Explicativo}

De acordo com Castells em "La Question Urbaine”, o sistema urbano organiza o conjunto das relações entre os elementos da estrutura espacial por ele definidos como subsistema $\underline{\text { Produção (P) - que se constitui dos meios de produção específicos, subsistema Consumo }}$ (C) - força de trabalho específica, subsistema Troca (T) - trocas ou intercâmbio entre P e C, Gestão (G) - regulação das relações entre P, C e T em função das leis estruturais que regulam a sociedade e subsistema Simbólico (S) - que expressa a especificidade do pensamento ideológico com relação às formas espaciais. Entendemos que, embora o modelo explicativo idealizado pelo autor tivesse por objeto toda uma cidade, sua utilização possa ser feita para um segmento econômico específico de produção e consumo, no caso os transportes urbanos, de maneira a estruturar o pensamento sobre os principais agentes intervenientes na construção dessa fração do espaço urbano. Vários autores utilizaram o modelo de Castells para o entendimento do setor de transportes urbanos, sua relação com o espaço urbano enfatizando as relações sociais e econômicas com foco na produção, no consumo e na gestão, como Nicolas e Bernard que estudaram a região parisiense ${ }^{3}$.

Optamos também por utilizar como estrutura explicativa para este estudo unicamente os subsistemas P, C e G, deixando de lado os demais subsistemas T e S. Tendo em vista que o subsistema $\mathrm{T}$ trata especificamente das trocas entre os diversos subsistemas e também das trocas internamente a cada subsistema, o mesmo poderia, na visão da cidade como um todo,

\footnotetext{
${ }^{2}$ CASTELLS, M. La Cuestion Urbana. Madrid: Siglo XXI de Espagna Editores S.A., 1979. 518 p. As idéias iniciais sobre os sistemas - produção, consumo e gestão - aparecem em um artigo datado de 1969 e que se consolidam em CASTELLS, M. Vers une théorie sociologique de la planification urbaine. Paris: Maspero, 1972.

${ }^{3}$ NICOLAS, J. e BERNARD, JC. Crise des Transports et Enjeaux Sociaux em Région Parisienne. Espaces et Sociétés. Paris, no. 13/14, p. 93-110, 1977.
} 
ser confundido com os transportes de pessoas e mercadorias, o que limitaria a análise ${ }^{4}$. O subsistema S também foi abandonado tendo em vista, segundo palavras do autor, sua característica ideológica no nível das formas espaciais, que foge ao objeto de estudo.

Assim, para efeito deste trabalho, entenda-se que: no subsistema Produção (P), inserem-se os grupos sociais interessados na reprodução dos meios de produção e da força de trabalho enquanto fator de produção; no subsistema Consumo (C) está incluída a população em geral, organizada ou não em grupos sociais distintos, enquanto alimentadora do processo de produção, e no subsistema $\underline{\text { Gestão }}$ (G) estão inseridas as diversas instituições públicas dos diversos níveis de intervenção governamental como mediadoras da relação entre Produção e Consumo.

Mesmo que nesse momento da organização da economia do país não se pudesse distinguir claramente entre as atividades de Gestão e Produção, uma vez que o governo participava fortemente na produção ${ }^{5}$ de infra-estruturas e serviços através das empresas estatais - companhias que efetivamente atuavam na produção direta - e até mesmo como consumidoras de bens e serviços, utilizar-se-á o modelo pela facilidade e simplicidade de raciocínio que ele permite, tentando, no entanto, apontar e relativizar os problemas em que se pode incorrer com sua utilização.

Lojkine fez à época uma ressalva ao modelo de Castells, quando este argumentou que, no que se refere à Gestão, o Estado só intervém no sistema se ele se reproduz mal, afirmando que a intervenção estatal é mais um elemento de produção e consumo que responde a um conjunto

\footnotetext{
${ }^{4}$ Na produção do espaço urbano, no que se refere a uma operação de transportes, não nos interessa as relações de troca entre P e C, uma vez que nosso tema se restringe à concepção - decisão - e implantação do sistema metroviário, enquanto produção e consumo e não à dinâmica de operação do sistema.

${ }^{5}$ Especialmente em países de periferia do sistema econômico: “[...] na América Latina a participação do Estado na produção do capital bruto varia hoje de 50 a 70\%.[...]” (informação verbal) extraído presencialmente de conferência de Fernando Henrique Cardoso, College de France, Paris, 18 maio 1981.
} 
de forças da comunidade urbana ${ }^{6}$. Assim, conclui que as decisões feitas pelos gestores das instituições públicas respondem às forças exercidas pelos subsistemas Produção, Consumo e pela própria prática da gestão urbana.

\subsection{Identificação dos principais grupos de interesse e seus possíveis comportamentos}

Vários autores contemporâneos ao processo de decisão analisado neste estudo, que desenvolveram idéias sobre o comportamento de atores nas atividades de produção e consumo dos transportes urbanos, baseados em observações feitas em diversos países, foram por nós consultados de forma a construir um quadro de pensamento sobre os possíveis interesses e comportamento de cada grupo social identificado ${ }^{7}$.

Assim, no âmbito do subsistema da Produção, são apresentadas as diferentes frações do capital que, à época, participavam do processo de produção do sistema de transportes

\footnotetext{
${ }^{6}$ LOJKINE, J. Contribution a une Theorie Marxiste de l'Urbanization Capitaliste. Cahiers Internationals de Sociologie, L II, 1972.

${ }^{7}$ Destacam-se alguns estudos apresentados no RENCONTRE DE RECHERCHE EXPLORATOIRE SUR LES TRANSPORTS URBAINS DANS LES PAYS EM DÉVELOPPEMENT. Paris, mars1981, mimeo.

- $\quad$ ALLOUCH, J. F. Le Système de Transport Collectif a Quito: Elements de Diagnostic.

- $\quad$ ARIAS, C. H. Transportation Planning - The Case of Quito - Ecuador.

- $\quad$ BAOUENDI, A. La Marche a Pieds dans le District de Tunis.

- $\quad$ BEAUVIR, C. Mobilité et Transports Urbains a Quito.

- $\quad$ BUDIN, K. Quelques Elements de Reflexion sur la Méthodologie des Études de Transports Urbains et Suburbains das les Pays en Voie de Développement.

- $\quad$ DE BUEN, O. Urban Transportation in Mexico: System Perspective and Research.

- $\quad$ DE LA BARRA, T. Urban Land Use and Transportation Research Requirements.

- $\quad$ DUNIN, L. F. La Croissance des Villes et les Transports.

- $\quad$ EL-HAWARY, M. e HUZAYYIN, A. S. Transportation and Other Impacts of Changing Shop Opening Hours in Greater Cairo, a General Overview.

- $\quad$ FIGUEIROA, O. - Transports et Développement Urbain dans le Cas de Quito.

- $\quad$ VARGAS, V. I. Le Transport de Personnes dans L’Aglomeration de Mexico.
}

Também são de interesse os estudos a seguir, apresentados no RENCONTRE DE RECHERCHE DE L'IRT -

INSTITUT DE RECHERCHE DES TRANSPORTS. Paris: sept. 1983, mimeo.

- $\quad$ GODARD, X. Les Différentes Forms de Transport Collectif a Brazzaville.

- $\quad$ MARCHAND, F. Diversité Institutionelle des Transports Urbains - Étatisation ou Coordination? Les Cas de Guadalajara, México.

- $\quad$ NICOT, B. H. La Place des Transports Informels das les Villes Indiennes.

Ver GAKENHEIMER, R.; EL-HAWARY; M. E MICHAEL, M. Toward Rationalizing the Transport Project Planning Process in Cairo, Egypt. Out. 1978, mimeo. 41 p. 
propriamente dito e suas relações com os agentes formais de decisão. Além da participação efetiva no processo de produção, tem relevância para este trabalho a importância relativa entre os interesses dos diversos grupos. Cabe observar que outros grupos e com outras lógicas de comportamento estão hoje presentes no processo de produção dos transportes urbanos, assim como começa a ganhar espaço uma visão geral focada na demanda.

No que se refere ao Consumo, interessa compreender a influência que os diferentes grupos sociais, enquanto futuros usuários da intervenção, exerciam nas decisões. Essas influências podiam ocorrer através da representação exercida pelos partidos políticos e associações de classe, ou através de organizações populares que começavam a se delinear nas cidades brasileiras nas décadas de 1970 e 1980 tais como os movimentos de base, as associações de moradores e outras. Ainda inclusos no subsistema Consumo, estavam os setores secundário e terciário da economia, cada um na sua integralidade, enquanto interessados na mobilização da força de trabalho. Quanto ao perfil deste subsistema, os grupos identificados continuam presentes nos dias de hoje e com lógicas de comportamento semelhantes. No entanto, a forma de representação se modificou com a presença expressiva das instituições do terceiro setor, o que tem aumentado as possibilidades de influenciar as decisões através da demanda.

Dentro do subsistema Gestão, as relações de poder, internas ao aparelho do Estado, estabeleciam uma rede de interesses e de forças entre as instituições que tinha um peso nas decisões. Convém lembrar que participantes do subsistema Gestão também se comportavam como consumidores e podiam exercer uma pressão maior do que consumidores stricto sensu. Da mesma forma, os atores presentes na produção efetiva da infra-estrutura de transportes estavam presentes no consumo enquanto futuros usuários do sistema. Ainda é atual o perfil deste subsistema, sendo que persistem orientações políticas mais gerais mas que ganham especificidades dentro da burocracia 
técnica de cada instituição, com maior ou menor autonomia e poder de decisão em função do estágio da organização administrativa em que se encontram.

A Ilustração 1 - Principais Subsistemas e Grupos de Interesse presentes no Processo de Decisão relativo ao Sistema Metroviário, abaixo, descreve os grupos teoricamente presentes no processo de decisão da implantação de uma infra-estrutura pesada de transportes, dentro do “framework” Produção, Consumo e Gestão.

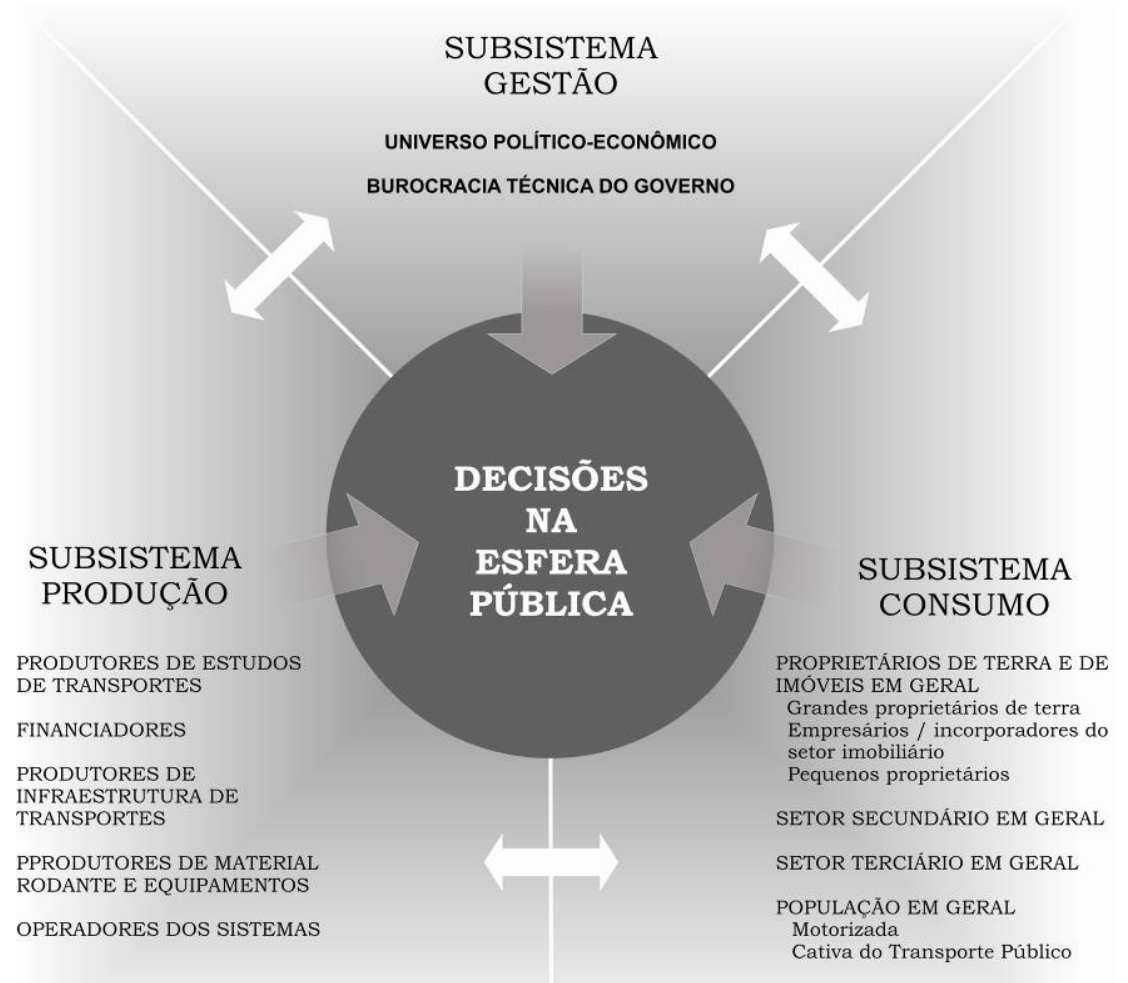

Ilustração 1 - Principais Subsistemas e Grupos de Interesse presentes no Processo de Decisão relativo ao Sistema Metroviário

\subsubsection{Perfil do subsistema produção dos transportes urbanos}

Os produtores de transportes em geral buscavam favorecer a reprodução do seu capital tentando inicialmente assegurar um volume de investimentos no setor e, em seguida, lutavam 
para que esses investimentos fossem significativos e perenes, estando especialmente interessados nos recursos públicos diretamente disponibilizados para o tipo de produto que podiam ofertar, podendo ser agrupados em:

- produtores de estudos de transportes - escritórios de planejamento e de projeto;

- financiadores dos empreendimentos (estudos e implantação) ligados aos sistemas de transportes;

- produtores de infra-estrutura de transportes;

- produtores de material rodante e de equipamentos para o setor e

- operadores dos sistemas de transportes.

É desse conjunto de atores - produtores de transportes - que se pode esperar as mais fortes influências sobre as instituições que efetivamente decidiam. De maneira geral, estes grupos representavam não apenas o empresariado local, mas também grupos estrangeiros, estando muitas vezes ligados ao capital nacional e estrangeiro.

Os escritórios de planejamento e de projeto, consultores nacionais ou estrangeiros, tinham a possibilidade de, através de seus estudos, abrir espaço para uma determinada tecnologia de transportes. A tecnologia recomendada, por outro lado, podia favorecer especialmente alguns produtores específicos de infra-estrutura, de material e de equipamentos - fossem eles nacionais ou estrangeiros.

Os financiadores de estudos e da implantação dos empreendimentos, por sua vez, tinham a força do recurso financeiro para impor algumas soluções técnicas e entraram no processo, na maioria das vezes, associados a algum grupo industrial facilmente identificável. 
Os produtores de infraestrutura, as grandes companhias construtoras nacionais e estrangeiras, tinham interesse na realização de grandes intervenções urbanas, de modo que ficassem garantidas suas oportunidades de trabalho e, preferencialmente, que as mesmas pudessem utilizar soluções tecnológicas de seu conhecimento. Seus desejos poderiam estar representados, não apenas junto às instituições decisórias, como também junto aos produtores de estudos e consultores, para que suas experiências e anseios pudessem ser considerados e eventualmente reunidos através de sociedades e consórcios. As ações desse grupo tendiam a ter bastante relevância junto aos principais agentes da decisão, seja buscando favorecimentos para as empresas nacionais - para uma política protecionista do mercado da construção civil -, seja buscando espaço para empresas estrangeiras - através de abertura de mercado para a tecnologia estrangeira.

Os produtores de material rodante e equipamentos se comportavam de maneira similar aos produtores de infra-estrutura, tentando também, além de responder ao mercado, trabalhar no sentido de gerar as necessidades do mesmo. A produção das grandes estruturas de transporte trilhos, vagões, locomotivas etc. - e de seu equipamento de operação - sistemas de automação, de bilhetagem etc. - era, e ainda é, um mercado muito cobiçado pelos produtores internacionais e no qual os interesses tendiam a se transformar em influências muito explícitas.

Finalmente, na operação dos transportes, podia-se observar a atuação de grupos privados e empresas públicas. No caso do gerenciamento público, a atuação das empresas carregava atividades de implantação (expansão e modernização dos sistemas, por exemplo) junto às de gerência da operação do empreendimento. As empresas privadas que operavam sistemas de transporte tinham tendência a se opor às soluções operacionais que elas não dominassem, ou 
então, às soluções de transporte que necessitassem de uma gerência coordenada em grande escala, geralmente feita pelo Estado, como no caso de metrôs. As empresas privadas desejavam manter a maior fatia possível do mercado operando com uma tecnologia conhecida. Eram, portanto, grandes empecilhos a alterações significativas que pudessem excluí-las ou que as obrigassem a grandes investimentos na modificação do seu capital fixo. Por outro lado, a gerência pública poderia tornar-se pouco eficiente e efetivamente mais custosa aos cofres públicos e ao usuário final.

\subsubsection{Perfil do subsistema consumo dos transportes urbanos}

De maneira geral, os consumidores dos transportes urbanos tinham, e ainda têm, interesse na implantação, expansão, modicidade de tarifas e a melhor operação dos sistemas, podendo ser agrupados em:

- proprietários de terra e de imóveis em geral:

grandes proprietários de terra;

empresários/incorporadores do setor imobiliário;

pequenos proprietários de imóveis;

- o setor secundário em geral;

- o setor terciário em geral;

- $\quad$ a população em geral:

população motorizada e

população cativa do transporte público.

Os proprietários de terra e de imóveis em geral procuram aumentar a renda de sua propriedade. Na medida em que existe uma relação direta entre valorização fundiária e 
imobiliária e aumento de acessibilidade ${ }^{8}$, este grupo almejaria melhorias nos sistemas de transportes. Pode-se supor que esses agentes obtenham vantagens - sem esforços ou investimentos visíveis - com a implantação de um transporte de massa, resultando na valorização de terrenos e especialmente dos usos comerciais e de serviços ${ }^{9}$.

Os grandes proprietários de terra são locacionalmente pouco dispersos - grandes propriedades (áreas de antigas fazendas) - e exercem em geral grandes influências. A elite da terra no Brasil sempre teve um peso importante nas relações sócio-econômicas, sendo comum os casos de implantação de benfeitorias públicas nas proximidades de suas propriedades, mesmo que essas localizações não sejam as mais indicadas para o desenvolvimento urbano. Estas influências se efetivam até hoje através de ligações diretas com o corpo institucional relações informais de amizade e parentesco; representação tradicional e constituída através de associações de proprietários; representação direta no âmbito dos homens políticos (muitas vezes porta-vozes da burguesia da terra) ou enquanto indivíduos proprietários ${ }^{10}$.

Os empresários/incorporadores do setor imobiliário, almejam incrementos de acessibilidade para aumentar o valor de seu empreendimento e, portanto, obter lucros maiores. Nos usos comerciais e de serviços essa relação é evidente, sendo, no entanto, mais complexa para os usos residenciais em função dos possíveis incômodos causados pelo aumento da movimentação em geral. Os incorporadores imobiliários são, em geral, locacionalmente ainda menos dispersos do que os proprietários de terra, concentrando-se nas áreas para onde

\footnotetext{
${ }^{8}$ Abordagem do setor dos transportes através dos conceitos da economia neo-clássica: THONSON, J. M. Modern Transportation Economics. USA: Penguin, 1974.

${ }^{9}$ Existem hoje mecanismos na legislação urbanística que incluem a participação dos proprietários nos custos com a implantação de sistemas de transporte tais como as contribuições de melhoria, por exemplo, que não existiam na legislação urbanística brasileira à época deste estudo.

${ }^{10}$ Representantes ou indivíduos oriundos da burguesia patrimonialista atingem postos importantes na carreira política e/ou na administração pública.
} 
cresce a demanda por habitações para classe média, média alta e alta, podendo converter-se em forças de influência bastante efetiva. Com relações nas instâncias da administração pública que regulam o uso e ocupação do solo, bem como junto aos representantes eleitos Câmara de Vereadores -, órgãos de representação pública, imprensa e outras formas de aproximação com relação aos agentes de decisão, os representantes desse setor querem ver favorecidas as possibilidades de utilização de terrenos em determinadas regiões da cidade através de regras de ocupação que primeiramente favoreçam determinadas localizações com um aproveitamento eficiente dos terrenos para, em seguida, almejar a permanência dessas regras. Quanto aos eixos de acessibilidade, muitas vezes é necessária a criação dos mesmos para que determinadas localizações possam ser favorecidas. Nas cidades brasileiras, grandes têm sido as influências no sentido de criar acesso, em especial para o transporte individual e de ônibus. No entanto, pleitos advindos desse grupo no sentido de criar eixos ferroviários que favoreçam maior mobilidade, praticamente não deixaram de existir desde os anos 1950, quando da opção pelo transporte rodoviário individual.

Os pequenos proprietários também respondem positivamente a um aumento de acessibilidade sendo, porém, mais sensíveis com relação aos inconvenientes quanto à qualidade de vida na região próxima às suas propriedades, onde a acessibilidade é substancialmente alterada, seja durante a implantação dos sistemas, seja pelo aumento do fluxo de veículos e de pessoas. No caso deste grupo, a demanda por acessibilidade é locacionalmente dispersa, podendo ou não assumir características de uma pressão efetiva, em geral através de associações de moradores ou de comerciantes.

O setor secundário em geral almeja o aumento de acessibilidade de suas empresas com o intuito de assegurar baixos custos na mobilização de sua força de trabalho. Este grupo se 
interessa pelo repasse à iniciativa pública dos custos relativos a essa mobilização, invocando o caráter social do serviço de mobilização. É um potencial demandatário dos transportes urbanos nas sociedades industriais. Nas sociedades de economia menos desenvolvida, onde uma grande parte da mão-de-obra está à margem do processo produtivo, o interesse do setor secundário em reivindicar transporte público é reduzido ou nulo. A abundância da mão-deobra não qualificada permite o repasse para a própria força de trabalho do custo de sua mobilização, impotente que é, tendo em vista a infeliz situação de competição em que está inserida. A mão-de-obra mais qualificada, mais escassa, tem um poder de reivindicação por transportes mais visível e eficaz, resultando nas atividades de “fretamento”, empreendidas por muitas empresas $^{11}$. Neste caso, o custo do transporte organizado pela indústria será inferior aos aumentos de salários necessários para que esta mão-de-obra possa pagar pela sua própria mobilização. Os industriais e as associações patronais que não são diretamente ligados à produção de material rodante pouco influem na tomada de decisões para a realização das grandes operações de transportes urbanos. No caso dos empresários produtores de insumos para os transportes, seu comportamento é semelhante aos demais empresários do setor secundário no que se refere ao interesse pelo aumento de acessibilidade para seus funcionários.

O setor terciário em geral, responsável pelas atividades de comércio e de serviços, almeja melhorias de acessibilidade de seus negócios para assim favorecer a reprodução de seu capital. Porém, dada a natureza da atividade, que se concentra historicamente nos locais de

${ }^{11}$ De acordo com COING, H. Car de Ramassage et Marché d'Emploi: le textile de Roubaix - Tourcoing. DGRST / BETURE, Paris, 8/75, nossa tradução:

De maneira geral, os proprietários de empresas esperam que a mão-de-obra tenha suas necessidades de moradia e transporte atendidas sem que a empresa tenha que intervir. [...] A mobilização e a reprodução da força de trabalho se organizam para suas nec essidades essenciais fora da esfera da produção. [...] As ações de transportes organisadas diretamente pelas empresas têm um caráter marginal com relação ao conjunto do sistema de mobilização da mão-de-obra.

Ver também CAMPANAC, E.; COING, H. Marché du Travail et Urbanisation: Le Rôle du Ramassage dans les Politiques d'Entreprises. La Vie Urbaine. Paris, 2/3/4, 1976. 
maior acessibilidade das cidades, o setor terciário não parece constituir um grupo de pressão quanto à demanda por transportes urbanos. Podemos afirmar que, teoricamente, este setor tem um interesse generalizado de que o gasto em transportes seja sempre decrescente, de modo a aumentar a parcela de despesas em outros itens do dispêndio familiar, nos quais se insere. Nesta hipótese, o setor não chega a mobilizar as associações de classe ou a influenciar direta ou indiretamente o corpo institucional.

A população em geral quer ver aumentada sua acessibilidade a custos mínimos cujos valores, entretanto, variam com a condição econômica das diversas classes sociais ${ }^{12}$. A população motorizada almeja melhorias no sistema viário que facilitem sua movimentação e cujos custos sejam absorvidos por toda a população na forma de produção da infra-estrutura de circulação viária. Uma parte dos custos dessa mobilização é absorvida pelo indivíduo através do capital investido no veículo e no trabalho efetuado ao se deslocar. Forma um grupo de pressão de alta representatividade, uma vez que, como classe média e/ou alta, a população motorizada está diretamente representada em todos os níveis de gestão, sendo também formadora de opinião. São pouco prováveis as pressões desse grupo em favor de decisões que favoreçam o transporte coletivo, mesmo que essas ações possam facilitar seu deslocamento, pois esse grupo não se sente diretamente beneficiado.

A população cativa do transporte público almeja melhorias no sistema de transporte coletivo, que possibilitem aumento de mobilidade a custos mais baixos, uma vez que, na maioria das vezes, essa população arca com os custos de seu próprio deslocamento ${ }^{13}$. As demandas se

\footnotetext{
${ }^{12}$ CHAPOUTOT, J; GAGNEUR, J. Mobilisation de la Force de Travail et Gestion des Transports Urbains. La Vie Urbaine. Paris, 2/3/4, 1976.

${ }^{13}$ Ver também NICOLAS, J. e BERNARD, JC. Crise des Transports et Enjeaux Sociaux em Région Parisienne. Espaces et Sociétés. Paris, no. 13/14, p. 93-110, 1977, que na página 94 afirmam que no caso parisiense “[...] A política de localização de moradias e emprego conduz a condições de transporte muito diferentes segundo o tipo
} 
concentram principalmente em três aspectos: 1 . a ampliação do sistema que possibilite o deslocamento para a população não inserida nas rotas de deslocamento existentes; 2. quando inseridos no sistema de deslocamento, expressa demandas por melhorias de serviços, freqüência, garantia, pontualidade etc. e 3. também quando inseridos no sistema de deslocamento, almejam modicidade de tarifas, ou seja, a manutenção ou diminuição dos custos dos serviços. Como grupo de pressão, seu poder de negociação é bastante fraco e sua representação praticamente nula dentro do sistema de representatividade tradicional. Nas práticas de representatividade informal no interior das instituições seu peso é também nulo. A possibilidade mais imediata de expressar seus anseios é através de movimentos sociais de protesto que mobilizam a opinião pública: quebra-quebras, bloqueios, acidentes etc ${ }^{14}$.

A confrontação de interesses conflitantes entre a população motorizada e a população cativa diminui o poder de negociação da população em geral junto aos agentes de decisão, facilitando a negociação dos interesses dos outros grupos.

\subsubsection{Perfil do subsistema gestão}

Podemos distinguir dois aspectos interessantes na gestão de empreendimentos estruturais do setor de transportes urbanos. O primeiro, de caráter mais geral, se refere ao universo políticoeconômico onde as ações se inserem, sendo estas então reguladas por direcionamentos mais amplos e gerais das políticas, das condições econômicas e dos interesses de cada esfera de

de força de trabalho que se pretende mobilizar. As exigências do tempo de deslocamento e do conforto dos serviços são resolvidas de maneira diferente para as diferentes classes sociais.” Nossa tradução livre do francês.

${ }^{14}$ Sobre os processos reivindicativos com relação aos transportes urbanos, MAY, N. e RIBEIL, G. Les Processus Revendicatifs em Matière de Transports Urbains. La Vie Urbaine. Paris, no. 2/3/4, 1976, distinguem tipos de reivindicações de usuários, aquelas que se restringem às condições individuais de utilização dos sistemas de transportes (atrasos, conforto etc), daquelas que discutem a produção e oferta do sistema, seja pelo poder público seja pelos empregadores. 
governo. O segundo, mais particular, se refere à organização interna das instituições públicas diretamente ligadas às operações dos sistemas específicos, onde se distingue o papel da burocracia do governo.

O aspecto mais geral das condições político-econômicas pode chegar a ter uma influência muito forte nas decisões de intervenções específicas, já que definem uma orientação geral para as tomadas de decisão, sendo portanto determinantes a nível macro. No capítulo anterior, que apresentou o contexto político e da organização da administração pública para as decisões relativas a grandes investimentos públicos no Brasil, pode-se observar as orientações mais gerais sobre a forma como as decisões são encaminhadas - se mais ou menos centralizadas, se mais ou menos dependentes do setor público enquanto produtor ou gestor dos empreendimentos e em função do modelo de gestão administrativa em vigor.

Segundo Poulantzas ${ }^{15}$, que debateu a questão dos engenheiros dentro dos sistemas organizacionais e também da burocracia enquanto uma classe de interesses com características diferentes dos demais trabalhadores, os engenheiros e técnicos em geral se inserem na produção capitalista baseados na relação próxima com o saber, investidos em funções legitimadas pelo conhecimento técnico. Enquanto detentores de conhecimento técnico no âmbito dos transportes, seja como executores ou contratantes de estudos, planos etc., os estamentos técnicos podem e muitas vezes exercem influência significativa junto aos agentes finais das decisões. Os administradores públicos que compõem a burocracia estatal podem eventualmente se comportar como agentes dos interesses de grupos sócio-econômicos

\footnotetext{
${ }^{15}$ POULANTZAS, N. Les Classes Sociales das le Capitalisme Aujourd'hui. Paris: Seuil, 1974. 347 p. Ver páginas 243 e 280. O autor defende a tese de que o trabalho intelectual, embora assalariado, não tem o mesmo ideário dos demais trabalhadores, constituindo-se numa burguesia mais próxima do capital e do poder e que apresenta contradições com relação à estrutura hierárquica da produção, comportando-se às vezes segundo os interesses dos trabalhadores e em outros momentos de acordo com os interesses do capital. No interior do aparato do Estado, o autor afirma que deve-se distinguir burocratização de burocracia, pois o primeiro termo se refere a uma tendência à materialização dos efeitos ideológico-políticos enquanto o segundo termo se restringe à organização das relações internas do tôpo à base.
} 
específicos. Na sua atuação, podem efetivamente ter como principal norteador o interesse público ou a leitura individual do que seja o interesse público e podem, veladamente, representar interesses específicos, desempenhando o papel de porta de entrada na administração pública. Não se constituem num grupo homogêneo, apresentando-se em diversas frações que podem representar interesses distintos em função do domínio de técnicas concorrentes. A tendência das instituições públicas é de favorecer o subsistema produção em geral - oferta - e, em especial, a produção dos transportes urbanos, em detrimento das reivindicações do subsistema consumo - demanda.

\subsection{Hipóteses a serem discutidas}

O levantamento de dados apresentado nos capítulos 3 e 4 relativo aos principais aspectos político-administrativos, economia, população e evolução da ocupação urbana da cidade do Rio de Janeiro, bem como o histórico da evolução dos deslocamentos metropolitanos, e ainda o histórico das iniciativas, públicas e privadas, apoios e obstáculos. Para a implantação do sistema metroviário na cidade, presentes no capítulo 5, levam à discussão de duas hipóteses centrais assim estabelecidas:

1. O Metrô-RJ não foi concebido como uma solução para um problema crônico de deslocamento na cidade, mas como um produto, isolado dos demais modos de transporte, apresentado como uma grande obra pública para a cidade num momento crítico de reorganização políticoinstitucional da região - a fusão dos dois estados, Guanabara e Rio de Janeiro. A rede de metrô projetada era inexpressiva face ao sistema de transportes existente na cidade, com relação ao número de passageiros transportados bem como com relação à sua localização.

2. Esse produto não foi significativo para a sociedade como um todo durante todo o período de maturação do empreendimento. A idéia só foi aceita e implementada quando um ou 
mais agentes de interesse dominaram o processo de decisão pela implantação do empreendimento e conseguiram encaminhar sua aprovação formal e sua construção.

A formulação das hipóteses secundárias abaixo relacionadas, e sua conseqüente comprovação ou negação, têm por objetivo reforçar ainda mais as hipóteses centrais, e partem das possibilidades de comportamento dos diversos grupos sociais que teoricamente poderiam influenciar as decisões da esfera pública sobre intervenções urbanas, em especial nos transportes urbanos. Pode-se prever quais seriam os grupos mais influentes presentes nos momentos mais significativos da decisão de se implantar um sistema metroviário para a cidade do Rio de Janeiro a serem confrontados com os elementos levantados empiricamente e que se constituem nos relatos da decisão organizados nos capítulos 5 e 6 . São eles:

1. os grupos ligados à propriedade imobiliária (terra e construção), tendo em vista a estreita relação entre a valorização da propriedade e o aumento de acessibilidade. Nos países de economia pouco desenvolvida, este grupo é politicamente muito forte e a valorização imobiliária é de grandes proporções.

2. os grupos ligados à produção dos transportes, que exercem pressões reais, já que existe uma relação direta entre os investimentos públicos e seu volume de trabalho. A ligação dos produtores com o capital estrangeiro reforça ainda mais as possibilidades de pressão.

3. a população em geral, que enquanto maior beneficiária dos empreendimentos estruturais de transportes urbanos, poderia se mobilizar para conseguir a realização de uma obra significativa para um incremento geral de acessibilidade. Embora a população cativa apresente pouca representatividade formal, sua capacidade de mobilização na forma de ocorrências de grande impacto, como fechamento de vias, quebra-quebras etc. pode ser considerável. A população motorizada parece ter um poder de barganha efetivo na demanda por ações nos transportes urbanos através da representatividade direta enquanto 
classe social dentro do sistema de gestão. Como consumidora, não tem idéia real dos custos de sua mobilidade e nem compreende o mecanismo pelo qual o transporte individual contribui para uma diminuição das despesas das empresas privadas de transportes - que se beneficiam diretamente com os investimentos em sistema viário - e para um aumento nos gastos públicos.

4. a burocracia técnica do governo tem um peso bastante acentuado na decisão, envidando esforços pela definição de uma técnica que ela domine, tornando-se muitas vezes permeável aos assédios de grupos econômicos.

As pressões desses quatro grupos principais parecem se materializar através das relações de influência de caráter informal: parentesco, amizade, corrupção etc. bem como através da imprensa que relata e muitas vezes toma partido de um outro grupo específico. As formas de representação formal das sociedades modernas - partidos políticos, associações de classe, de moradores etc. - não parecem ser suficientemente efetivas no caso da implantação do sistema metroviário na cidade do Rio de Janeiro.

Contrariamente, os grupos ligados aos setores secundário e terciário em geral não parecem influenciar as decisões mesmo que tenham representatividade e força para isso. Os primeiros, dada a situação de marginalidade da mão-de-obra (exército de reserva), não têm interesse em influenciar decisões favorecendo os transportes urbanos, uma vez que a parcela dos custos da mobilização da força do trabalho são absorvidas principalmente pelo trabalhador que tem pouco poder de engendrar mudanças a seu favor. Os segundos, já naturalmente bem localizados, só se interessam em investimentos nos transportes urbanos no momento em que as deseconomias de aglomeração impedem o desenrolar conveniente do seu volume de negócios. 
CAPÍTULO 03 


\section{A CIDADE DO RIO DE JANEIRO}

\section{Aspectos político-administrativos, economia, população e evolução da ocupação urbana}

O sistema metroviário da cidade do Rio de Janeiro, trechos em operação e em construção, está integralmente situado no território que é hoje definido como Município do Rio de Janeiro. Essa área abrigou funções das três esferas de governo e suas feições guardam uma relação direta com a história do país. Até a primeira metade do século XX, foi o principal centro político, econômico, financeiro e cultural da nação, contendo a sua maior concentração populacional. Ainda hoje, o Rio de Janeiro abriga atividades altamente especializadas, exportando diversos serviços para todo o país, mesmo subtraída a condição de capital da República.

Enquanto capital da nação durante dois séculos, a cidade do Rio de Janeiro foi sede de instituições e de empresas de abrangência e responsabilidades nacionais. Manteve instituições estaduais durante o curto período de existência do Estado da Guanabara, 1960-1974, congruentes às instituições municipais da cidade do Rio de Janeiro, numa superposição de Município e Estado por 14 anos $^{1}$. A partir de 1974, quando da reorganização física e políticoadministrativa dos antigos Estados do Rio de Janeiro (cuja capital era a cidade de Niterói) e da Guanabara (cuja capital era a cidade do Rio de Janeiro) através da fusão dos mesmos num só Estado $^{2}$, a área manteve os encargos locais de município, recebendo adicionalmente a função de capital do novo Estado do Rio de Janeiro. Às incumbências municipais e estaduais, também se somaram as funções formais de núcleo da Região Metropolitana do Rio de Janeiro

\footnotetext{
${ }^{1}$ Essa área é muitas vezes chamada na literatura de Cidade-Estado. Ver Aspásia Camargo, Ana Maria Brasileiro e Ângela Moulin S. Penalva Santos.

2 BRASIL. Lei Complementar no. 20 de 01/07/1974.
} 
- RMRJ - compreendendo 14 municípios durante o período analisado por este estudo ${ }^{3}$, acrescentando demandas e obrigações regionais a esse núcleo principal. Este capítulo discorre de maneira sucinta sobre aspectos históricos e políticos, economia e evolução da ocupação urbana da região. Esta descrição deverá compor o cenário à época - décadas de 1960 e 1970 na qual se desenrolam as decisões concernentes a este estudo - a implantação do sistema de Metrô do Rio de Janeiro - remetendo o leitor aos principais fatos e características da área do atual Município do Rio de Janeiro.

\subsection{Evolução político-administrativa}

Em 1763, a cidade do Rio de Janeiro, então parte da Província do Rio de Janeiro, foi elevada a Capital da Colônia, quando o açúcar deu lugar à extração de minérios como sua principal atividade, transferindo para as capitanias do sul do país o centro geográfico da produção econômica. Próxima às Minas Gerais e funcionando como principal porto de escoamento da produção para o exterior, a cidade do Rio de Janeiro cresceu ao abrigar as atividades administrativas da maior colônia portuguesa. Testemunhou as mudanças no status político da nação que passou a Vice-Reinado e a seguir, em 1808, quando da instalação da Família Real no Brasil, foi o Rio de Janeiro elevado à sede do Reino-Unido de Portugal, Brasil e Algarve.

Ao longo das mudanças institucionais e políticas do país que se seguiram, o território do Rio de Janeiro manteve-se intacto com o mesmo perímetro. Em 1822, quando o país se tornou independente de Portugal, a cidade passou a Capital do Império e em 1889, a Capital da República, na forma do então denominado Município Neutro. A Constituição de 1891, que

\footnotetext{
${ }^{3}$ A RMRJ foi criada em 01 jul. 1974, pela mesma lei que estabeleceu a fusão dos dois estados, sendo nessa época composta por 14 municípios; em 1994, passa a ter 17 municípios, sendo incorporados Belford Roxo, Guapimirim, Japeri e Queimados e excluído o município de Petrópolis.
} 
estabeleceu os estados da nova federação, determinava que o Município Neutro se transformasse em Distrito Federal e portanto, sede da República Federativa do Brasil, assim permanecendo até o momento da mudança da capital para o Planalto Central, quando então essa área deveria se constituir em novo estado da república. Assim, em 1960, quando da mudança do Distrito Federal para o Estado de Goiás, com a fundação de Brasília, passou a constituir o Estado da Guanabara, novo estado, espacialmente encravado no Estado do Rio de Janeiro.

Durante esses dois séculos, a cidade do Rio de Janeiro foi sede das instituições e portanto, das decisões de caráter nacional, e grande parte de sua vitalidade foi resultado das atividades inerentes à sua função de capital nacional. As atividades de administração urbana atendiam às demandas por obras e serviços de natureza local e, ao mesmo tempo, respondiam pelas obras urbanas que as condições de capital nacional exigiam.

Nas três últimas décadas enquanto Distrito Federal, período entre 1930 e 1960, a região experimentou um processo de intensa urbanização que ultrapassou os seus limites administrativos, num processo de metropolização que acrescentou às suas funções de gerência local e nacional, uma demanda por gestão de caráter regional, metropolitana, ainda não institucionalizada porém, de facto.

A partir de 1960, quando da mudança da capital para Brasília e da constituição do Estado da Guanabara, a cidade-estado passou por importantes alterações institucionais. Grande parte dos órgãos federais foi transferida para o Planalto Central; no começo lentamente, e mais rapidamente a partir de 1964. As instituições que desempenhavam funções de caráter municipal do Distrito Federal se transformaram em instituições estaduais. Cogitou-se na época a repartição do Estado da Guanabara em unidades municipais menores, mas manteve-se 
a unidade territorial com o objetivo de facilitar a gestão. Tendo em vista a legislação tributária federal que regulamenta a arrecadação dos impostos e o repasse de participações aos estados e municípios, o Estado da Guanabara arrecadava impostos e recebia dotações referentes às duas condições administrativas - estado e município -, a serem aplicados na mesma área geográfica, subtraído das responsabilidades da gestão estadual quanto à organização de municípios. Assim, dos tributos repassados aos estados e municípios, a Guanabara recebia as cotas-parte referentes ao Estado e ao Município. O Imposto sobre Circulação de Mercadorias, por exemplo, recolhido pelo Estado da Guanabara, era totalmente aplicado na cidade. As estruturas administrativas estadual e municipal mantidas na cidade do Rio de Janeiro, sendo coincidentes, eliminavam despesas correntes e de capital significativas ${ }^{4}$. Pode-se afirmar que dentro da estrutura tributária do país, a Guanabara manteve, no período de 1960 a 1974, uma situação bastante favorável de captação e utilização de recursos.

Cogitada a reorganização política e administrativa da região desde a época da mudança do Distrito Federal para Brasília, consolidou-se finalmente em 1974 a fusão dos dois estados, Estado da Guanabara e o antigo Estado do Rio de Janeiro, numa única unidade estadual denominada Estado do Rio de Janeiro, cuja capital é a cidade do Rio de Janeiro, que se transformou definitivamente em município. Ver Ilustração 2 - Estado do Rio de Janeiro resultante da fusão do antigo Estado do Rio de Janeiro e do Estado da Guanabara. A cidade, enquanto ente federativo municipal, não tinha estrutura administrativa que pudesse responder aos problemas locais, tendo que rapidamente reforçar os instrumentos de captação de recursos usualmente utilizados pelos municípios brasileiros, como IPTU, ISS e outros, que, na situação institucional anterior, tinham pouca ou nenhuma expressão.

\footnotetext{
${ }^{4}$ Segundo LODDER, C. A. Distribuição de Renda nas Áreas Metropolitanas. IPEA, Coleção Relatórios de Pesquisa no. 31. Rio de Janeiro, IPEA, 1976. 103 p.
} 


\section{Ilustração 2 - Estado do Rio de Janeiro resultante da fusão do antigo Estado do Rio de Janeiro e do Estado da Guanabara}

Niterói perdeu a função de capital do antigo Estado do Rio de Janeiro e passou a compor a Região Metropolitana do Rio de Janeiro que foi instituída em 15 de março de 1975; na mesma data foi criada a FUNDREM - Fundação para o Desenvolvimento da Região Metropolitana do Rio de Janeiro. Ver Ilustração 3 - Estado do Rio de Janeiro e os municípios da Região Metropolitana do Rio de Janeiro.

Assim, a partir de 1974, a região passou a ter uma organização mais racional no que concerne à real área de influência econômica da cidade do Rio de Janeiro, através de um novo desenho institucional, mesmo que este tenha apresentado impactos positivos e negativos - de natureza econômica, política e social -, amplamente discutidos à época 5 .

\footnotetext{
${ }^{5}$ Afirmação calcada em pesquisa nos principais jornais do Rio de Janeiro no ano de 1974: Jornal do Brasil e O Globo.
} 


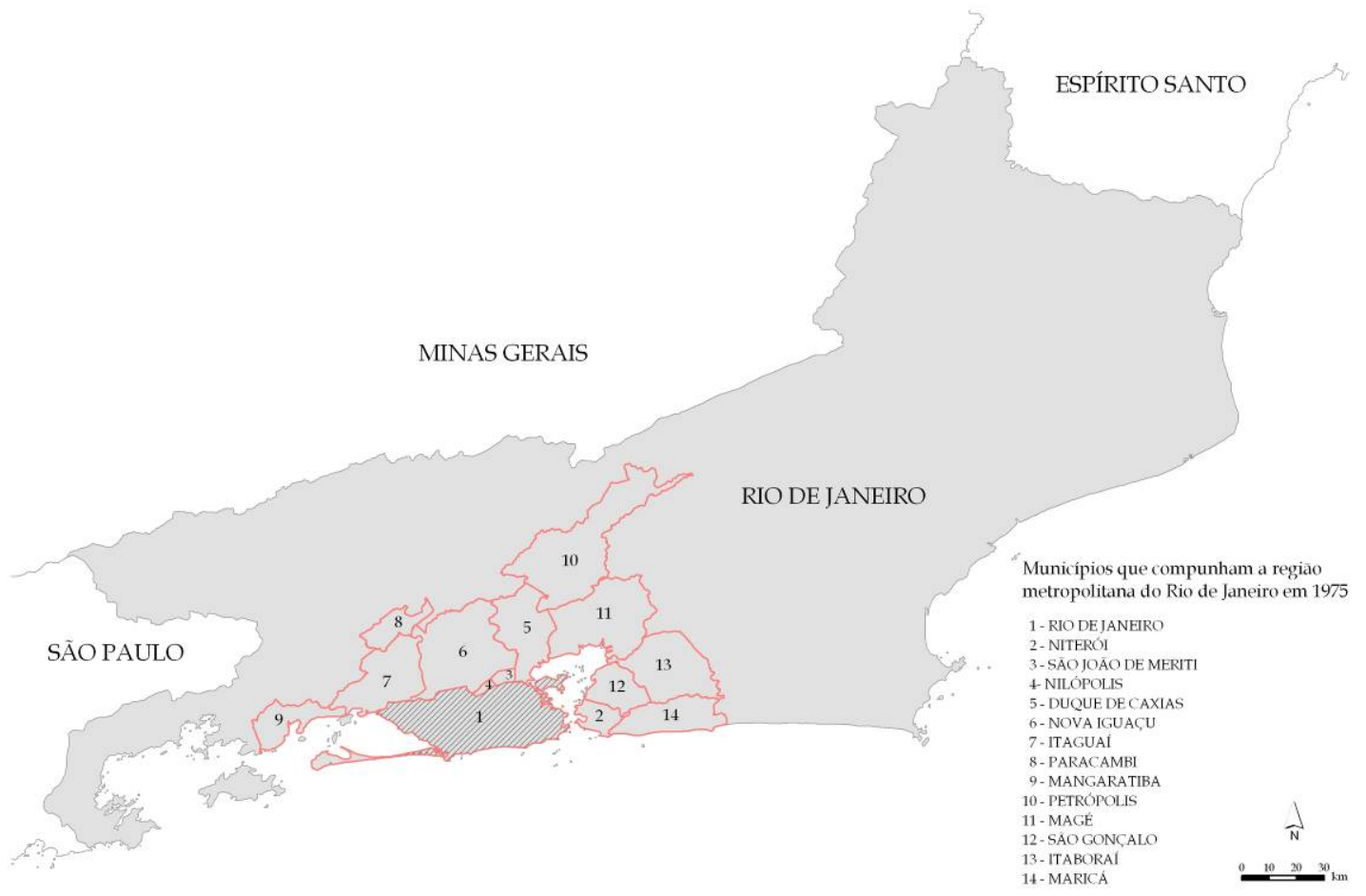

Ilustração 3 - Estado do Rio de Janeiro e os municípios da Região Metropolitana do Rio de Janeiro

A cidade passou a desempenhar, a partir de meados da década de 1970, portanto, funções administrativas municipais locais bem definidas, funções metropolitanas de gerência dos municípios da Região Metropolitana do Rio de Janeiro - como município núcleo - e funções estaduais com os encargos de gestão de todos os municípios fluminenses ${ }^{6}$.

Até 1960, a cidade do Rio de Janeiro era o principal espaço onde se desenrolava o jogo político nacional, onde os grupos de interesse local se confundiam com os grupos de interesse nacional. A gestão da cidade se confundia com a gestão da Capital e, portanto, do grande centro político, sendo o Prefeito do Distrito Federal nomeado diretamente pelo Presidente da República. Grande parte dos investimentos feitos na cidade foi realizada com recursos da União. As soluções urbanas tinham objetivos de caráter local - educação, saúde, saneamento, 
transportes coletivos, rodovias, ferrovias etc. - coexistindo com alguns dos objetivos da função de Capital - embelezamento, grandiosidade, equiparação com as grandes capitais do mundo etc. - noções nem sempre coincidentes e muitas vezes conflitantes. É difícil diferenciar no discurso da época as preocupações com o habitante que se desloca, trabalha, estuda, dentre outras funções, das preocupações fruto das demandas de caráter simbólico de uma capital, independentemente do contexto urbano que as produzem.

A cidade vivenciou, durante um curto período de tempo, um processo de passagem de uma visão predominantemente nacional para uma visão local, e o entendimento e enfrentamento de seus problemas reais passou por uma mudança estrutural. A formação do Estado da Guanabara foi um rito de passagem na construção dessa consciência local. Com a cidade-estado, iniciou-se um processo de formação de lideranças para a eleição de governadores e deputados cuja plataforma de interesses passou a ser principalmente local. Essas lideranças tiveram a tarefa de reconstrução de uma área que foi alijada de grande parcela de seus recursos humanos e parte de sua base econômica e administrativa, quando da consolidação do processo de mudança do Distrito Federal para Brasília. Grande parte dos empregos gerada pelo Governo Federal foi transferida e com ela uma parcela considerável das classes média e alta. Somente algumas corporações, pela sua autonomia político-administrativa, puderam permanecer, usufruindo das condições peculiares da cidade reforçadas pelas suas próprias características e áreas de atuação, como a Petrobrás, a Companhia Vale do Rio Doce, a CEF, o BNDES, o BNH, a Previdência Social/Dataprev, dentre outras.

\footnotetext{
${ }^{6}$ Entre 1974 e 1984, o Estado do Rio de Janeiro tinha 64 municípios. Em 2004, era composto de 92 municípios, de acordo com o IBGE.
} 
A Ilustração 4 - Administrações na área da cidade do Rio de Janeiro apresenta a gama de condições institucionais pelas quais a cidade passou, enquanto Distrito Federal e portanto Capital da República, enquanto cidade-estado (Estado da Guanabara) e enquanto município, Capital do Estado do Rio de Janeiro. Permite a visualização das datas-marco de mudança de status administrativo, do tempo relativo de duração de cada período de governo e da condição de legitimidade de cada governante - se eleito ou nomeado. Pode-se observar que durante todo o período enquanto Distrito Federal os governantes foram nomeados e que no período de dez anos, entre 1960 e 1970, enquanto Estado da Guanabara, houveram eleições, podendo os cidadãos escolherem seu mandatário. Sucede-se um período de nomeações e eleições indiretas para governadores e prefeitos, de forma que somente a partir de 1986 a região consegue efetivamente eleger suas lideranças.

Os três governos do Estado da Guanabara foram governos de oposição ao Governo Federal, fato raro no país durante o período. O $1^{0}$ Governador da Guanabara, Carlos Lacerda, eleito pela UDN - União Democrática Nacional -, opôs-se aos presidentes pré-1964, teve participação no golpe militar que depôs o Presidente Jango Goulart, indispondo-se porém, mais tarde, com o governo militar. Em 1965, o Governador Francisco Negrão de Lima foi eleito em oposição ao grupo de Carlos Lacerda, e também manteve pouca afinidade com o Governo Federal. Chagas Freitas foi o terceiro Governador da Guanabara, apoiado por fortes grupos locais, também em oposição ao poder central.

Essa oposição ao Governo Federal, no entanto, não se constituiu numa oposição ideologicamente construída. Contra um governo de força, ela se fundamentou principalmente na representação dos grupos locais que não estavam presentes na esfera federal, destituídos de sua expressão nacional. Na fragilidade ideológica da oposição carioca residiu a condescendência 


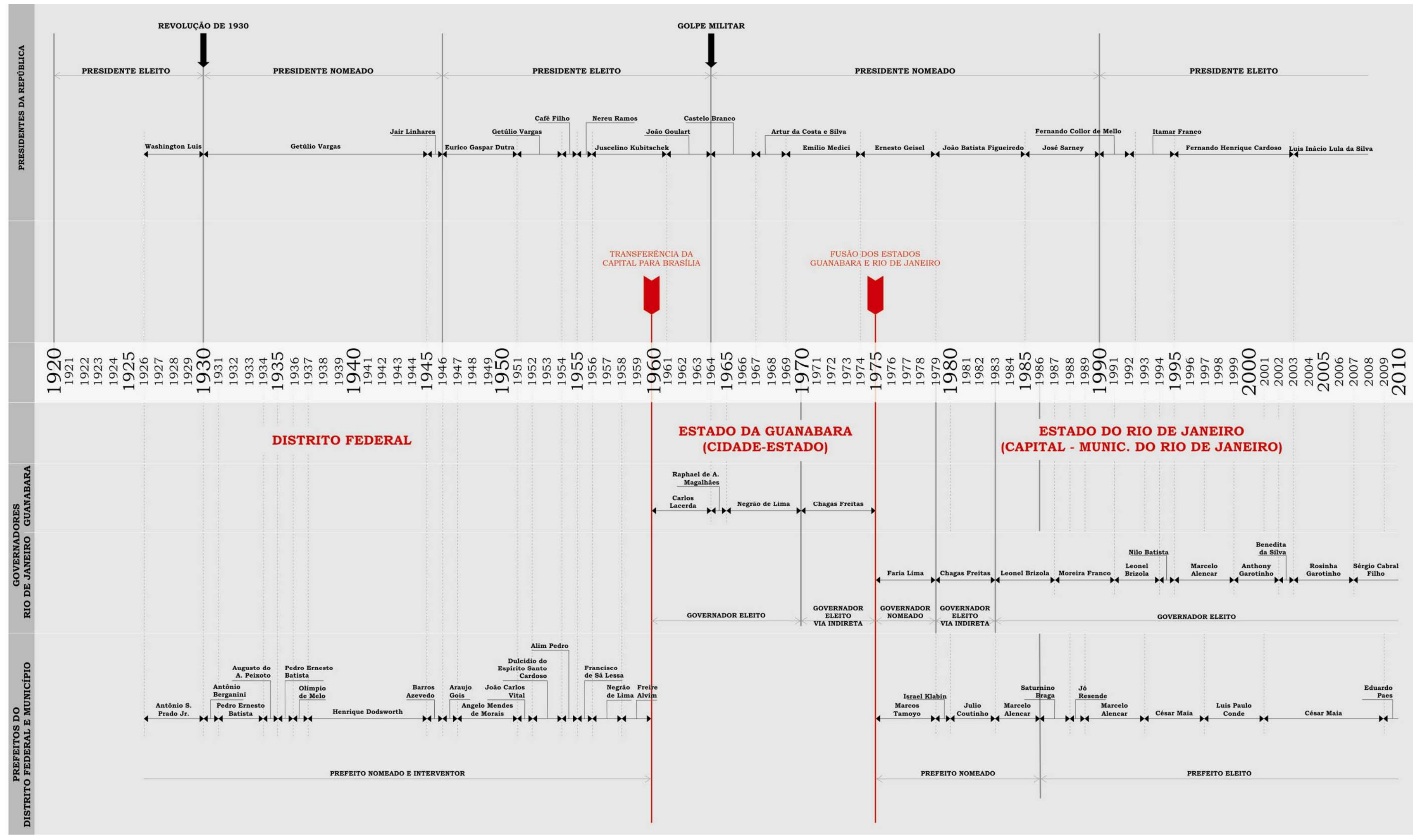

Ilustração 4 - Administrações na área da cidade do Rio de Janeiro 
federal para com os governos estaduais da Guanabara, denominada “oposição consentida”, o que não gerou grandes cortes nos aportes de recursos federais para o Estado, ou outras medidas restritivas que seriam coerentes num quadro de oposição real aos governos militares ${ }^{7}$

Em 1974, com a fusão dos dois estados - ato do Governo Federal considerado por muitos como arbitrário, porém em concordância com expressivos grupos locais, como a Federação das Indústrias do Estado do Rio de Janeiro - FIERJ -, foi dado mais um passo na construção dessa consciência local. Avaliada como um golpe quase mortal à economia da região ${ }^{8}$, a fusão levou o Município do Rio de Janeiro a herdar a gestão de todos os problemas de uma economia pouco dinâmica dos, à época, 64 municípios fluminenses. O quadro tributário do novo Estado do Rio de Janeiro se mostrou fortemente desfavorável à cidade do Rio de Janeiro, quando comparado com a situação anterior à fusão. A maior parte do ICM (principal item da Receita Estadual na época) continuou a ser principalmente captado na área do município, sendo, no entanto, aplicado à totalidade dos municípios. O novo estado se viu obrigado a investir numa região muito menos desenvolvida do que a capital, desempenhando um papel propulsor na economia estadual. Segundo Ana Maria Brasileiro, em A Fusão: Análise de uma Política Pública, páginas 34 e 35:

[...] a Guanabara apresentava índices de participação no produto interno bruto duas vezes superiores aos do Estado do Rio; participava em três vezes mais do que ele no valor da produção do setor de serviços. Perdia, de longe, na produção agrícola e ganhava, pouco, na produção industrial.

O primeiro governador da fusão, 1975-1979, Almirante Floriano Peixoto Faria Lima, confirmado pela Assembléia Legislativa no quadro político-institucional de eleições indiretas

\footnotetext{
${ }^{7}$ Entrevistas feitas em 25 mar. 1981, 03 abr. 1981, 06 abr. 1981 e 08 abr. 1981 com Josef Barat, em 08 mar. 1982 com Alberto Dinis e em 12 mar. 1982 com Rafael de Almeida Magalhães, enfocando a questão do posicionamento político dos governantes do Estado da Guanabara.

${ }^{8}$ A partir de BRASILEIRO, A. M. A Fusão: Análise de uma Política Pública, IPEA. Série Estudos para o Planejamento, no. 21. Brasília, 1979. 364 p.
} 
nos estados, foi imposto pelo Governo Federal em desconexão com os anseios locais. O primeiro Governo da Fusão se comportou como uma agência do Governo Federal, de características tecnocratas, como elemento racionalizador e organizador da nova administração estadual e municipal. Recuperando o governo estadual para os grupos locais, Chagas Freitas, representante do clientelismo local, sucedeu Faria Lima, no período 19791983. Mas foi somente o $3^{0}$ governo do novo estado, 1983-1987, que materializou a formação de oposições reais ao Governo Federal, num momento em que estas emergiam em quase todo o país: as eleições diretas de 1982 deram vitória a Leonel Brizola, deputado pelo Estado da Guanabara no governo João Goulart, voz da oposição real formada no novo Estado.

O cargo de Prefeito do Município do Rio de Janeiro que passou a existir a partir da fusão dos dois estados foi preenchido inicialmente por indivíduos indicados pelos governadores, conforme determinação da Constituição Federal de $1946^{9}$. Nas três primeiras administrações estaduais fluminenses, a figura do prefeito não teve a importância nem a autonomia que possui em outros estados e nem o empenho na gestão da cidade que se espera de tal função. Todas as intervenções urbanas de maior envergadura ainda dependiam diretamente do Governador. Mais uma vez, as lideranças locais foram transferidas para uma outra esfera administrativa, a estadual, criando vazios na administração local, que ainda necessitaram de um período de tempo para sua reorganização. É compreensível essa demora na efetivação da figura do Prefeito dissociada do Governador no processo de consolidação das novas condições territoriais e políticas. Ao mesmo tempo, a nova administração estadual priorizava as aspirações do município do Rio de Janeiro, levando anseios locais à esfera da decisão estadual.

\footnotetext{
${ }^{9}$ Embora a Constituição Federal de 1946 dispusesse que os prefeitos dos municípios seriam eleitos, o mesmo diploma legal determinava que nas estâncias hidrominerais, nos municípios definidos por lei federal como base
} 
Neste terceiro governo estadual, quando se poderia esperar um aperfeiçoamento no processo administrativo, foi ainda a figura do Governador Brizola que centralizou a maior parte das decisões de caráter municipal. Lideranças locais e nacionais se sucederam: Moreira Franco, governador no período 1987-1991; Leonel Brizola novamente em 1992-1994; curto período de Nilo Batista, 1994-1995; Marcello Alencar em 1995-1999 e unicamente no final do século XX, já no sétimo período de governo, que o Estado do Rio de Janeiro passou a ser governado por lideranças fluminenses e não mais cariocas ou de representação nacional. Chegaram ao poder Anthony Garotinho, 1999-2002, e Rosinha Matheus Garotinho, 2003-2006, oriundos do norte do estado e que trouxeram para a esfera de decisão uma visão do restante do estado, em especial da região que hoje recebe grandes investimentos com a exploração do petróleo, intercalados pelo curto período de menos de um ano em 2002, quando governou Benedita da Silva, líder popular de grande expressão local.

Cabe acrescentar que até hoje ainda não está integralmente aceita pela sociedade local a função da cidade do Rio de Janeiro enquanto capital do Estado do Rio de Janeiro, pois parte significativa das forças políticas cariocas, dominantes à época, ainda não se adequou a essa situação. Observa-se atualmente um movimento de tentativa de reversão do processo de fusão dos dois estados, a chamada des-fusão, encabeçado pela ONG Autonomia Carioca. Comungam com essa visão autonomista nomes expressivos, dentre eles: a Vereadora Aspásia Camargo, o Secretário Municipal de Urbanismo Alfredo Sirkis (da gestão César Maia, 20052008) e a economista Maria Silvia Bastos Marques $^{10}$. A imprensa local tem se manifestado

ou porto militar de importância para a defesa nacional, os chefes do poder executivo seriam nomeados pelo Governador do Estado.

${ }^{10}$ MOTTA, N. Fusão, confusão, separação. Folha de São Paulo, 18 mar. 2005: “[...] cresce o apoio político e popular à proposta da economista Maria Silvia Bastos Marques da des-fusão - talvez a única possibilidade de salvação para o Rio de Janeiro, reassumindo sua autonomia e deixando o Estado do Rio de Janeiro para os políticos fluminenses [...]” e OSÓRIO, M. A Fusão: equívocos e memória. Disponível em: <http://www.corecon-rj.org.br/artigos_det.asp?Id_artigos=6>. Acesso em: 05 ago. 2005. 
recentemente de forma a sistematizar as perdas e os ganhos da Guanabara, e portanto da cidade do Rio de Janeiro, com a fusão.

Pode-se observar que até a data da transferência da capital para Brasília e conseqüente perda abrupta da condição de sede do poder nacional, as decisões relativas à implantação de empreendimentos/obras estruturadores na região eram efetivamente tomadas com uma visão nacional e local indissociada: os governantes eram braços da esfera federal por esta nomeados. Como veremos mais adiante, é durante a condição de cidade-estado que ocorreu o maior afluxo de iniciativas pela implantação do sistema metroviário, numa fase de construção de uma identidade local independente. Mas foi só no momento da efetivação de uma nova organização administrativa, com a fusão dos dois estados, que o trecho inicial do Metrô-RJ veio a ser construído.

\subsection{População e economia}

A cidade do Rio de Janeiro experimentou um crescimento acentuado no século XVIII, resultado da extração de minério na região sudeste do país, principal atividade econômica da Colônia. Desenvolveu a função de porto, escoando parte da produção de ouro e pedras preciosas de Minas Gerais, ao mesmo tempo em que se tornava passagem obrigatória de pessoas e mercadorias para o interior. Nela se instalou importante comércio atacadista.

Com a decadência das minas de ouro no século XIX, a produção de café na região do Rio de Janeiro substituiu o minério como principal produto de exportação do país, então já independente de Portugal. O porto do Rio de Janeiro passou a escoar grande parte dessa produção. A cidade continuou a desempenhar importante função político-administrativa, 
desenvolvendo-se também como centro comercial e financeiro que reproduziu e gerenciou a riqueza gerada na sua região próxima. A instalação das primeiras ferrovias acentuou a acessibilidade do Rio de Janeiro e ampliou o mercado e a sua área de influência geográfica. O longo período durante o qual o país obedeceu ao modelo exportador de produtos primários e importador de produtos industrializados beneficiou a expansão do porto que desempenhou ambas as funções. Ao final do século XIX a cidade do Rio de Janeiro era um dinâmico centro administrativo, financeiro e comercial com uma população da ordem de 700.000 habitantes.

A monocultura do café entrou em declínio na região, deslocando-se através do Vale do Paraíba, indo beneficiar São Paulo como região de influência e o porto de Santos, mais próximo, para o escoamento do produto. A região de São Paulo começou a crescer vigorosamente, com o ganho de acessibilidade que a ferrovia - Santos, São Paulo, Jundiaí, interior do estado - propiciou para a nova fronteira agrícola.

Mas o Rio de Janeiro continuou a se desenvolver, uma vez que a cidade desempenhava atividades urbanas variadas e especializadas, prestando serviços cada vez mais específicos, atraindo novos habitantes e auto-alimentando a espiral do crescimento urbano. A primeira fase do processo da industrialização brasileira alcançou a cidade já no século XX, que, de início, produziu bens de consumo intermediários e de produção. A aglomeração urbana se consolidou ainda mais, reforçando as funções de centro administrativo, financeiro e comercial e gerando riquezas a partir da nova função industrial e do acelerado desenvolvimento do setor terciário que as atividades de sede do Governo Federal lhe demandavam. O Rio de Janeiro manteve-se nas três primeiras décadas do século XX como principal centro prestador de serviços do país. 
Em São Paulo, na mesma época, o desenvolvimento da indústria concomitantemente ao excedente da importante atividade agrícola cafeeira gerou um ritmo de desenvolvimento e acumulação de riquezas ainda mais intenso do que no Rio de Janeiro. Aos poucos, percebia-se no cenário nacional a perda da hegemonia do Rio de Janeiro para São Paulo como principal centro produtor da nação. Os rendimentos da agricultura foram os grandes financiadores da industrialização paulista que acolheu mão-de-obra especializada através da imigração européia e asiática, muito intensa durante as primeiras décadas do século. Uma indústria e uma agricultura mais dinâmica e, portanto geradoras de maiores recursos se implantou na região e São Paulo pôde construir sua infra-estrutura e super-estrutura urbanas independentemente do Governo Federal.

A cidade do Rio de Janeiro continuou crescendo, ver Tabela 1 - Evolução Demográfica dos Municípios do Rio de Janeiro e São Paulo 1872 - 1980, porém, com uma base industrial muito menos sólida do que a paulista e com suas atividades cada vez mais concentradas no setor terciário.

A região de São Paulo passou a ser o locus do processo de concentração industrial nacional, tornando-se o maior centro industrial e desenvolvendo atividades terciárias que polarizavam uma região importante do país; o município de São Paulo ultrapassou o Rio de Janeiro em valor absoluto de população residente em meados da década de 1950. 
Tabela 1 - Evolução Demográfica dos Municípios do Rio de Janeiro e São Paulo 1872 1980

\begin{tabular}{|c|c|c}
\hline ANO & RIO DE JANEIRO*(Município) & SÃO PAULO (Município) \\
\hline $\mathbf{1 8 7 2}$ & 274.972 & 31.385 \\
$\mathbf{1 8 9 0}$ & 522.651 & 64.934 \\
$\mathbf{1 9 0 6}$ & 811.443 & 239.820 \\
$\mathbf{1 9 2 0}$ & 1.157 .873 & 579.033 \\
$\mathbf{1 9 4 0}$ & 1.764 .141 & 1.326 .261 \\
$\mathbf{1 9 5 0}$ & 2.377 .451 & 2.198 .096 \\
$\mathbf{1 9 6 0}$ & 3.307 .163 & 3.825 .351 \\
\hline $\mathbf{1 9 7 0}$ & 4.315 .746 & 5.978 .977 \\
\hline $\mathbf{1 9 8 0}$ & 5.183 .992 & 8.587 .665 \\
\hline
\end{tabular}

* corresponde à população urbana do Rio de Janeiro.

Fonte: Recenseamentos Gerais do Brasil, IBGE.

Em 1980, o Município do Rio de Janeiro, núcleo da RMRJ, abrigava 5.090.725 habitantes, concentrando 56,5\% da população metropolitana. Constituía-se num grande mercado de consumo, com a maior renda per capita do país. Do total da população do Estado, em 1980, 11.489.797 habitantes, a RMRJ, com 9.018.637 habitantes, participava com 78,5\%, representando, entretanto, 81,5\% do total da população economicamente ativa. Grande parte da população do município não era nascida na região, cerca de 35,2\% de não-naturais na população total. A migração, bastante atenuada na década de 1970 era quase toda de origem urbana, 95,9\% em $1970^{11}$.

Foi a partir da segunda metade do século XX que a região do Rio de Janeiro experimentou o que se cunhou de esvaziamento econômico da Guanabara ${ }^{12}$, fenômeno da perda do dinamismo econômico da região, cujas causas principais parecem ser: primeiro, o modelo concentrador de riquezas na região de São Paulo a partir da industrialização paulista de

\footnotetext{
${ }^{11}$ Informações do Plano Urbanístico Básico da Cidade do Rio de Janeiro, 1977.

${ }^{12}$ Tese discutida por BRASILEIRO, A. M. A Fusão: Análise de uma Política Pública, IPEA. Série Estudos para o Planejamento, no. 21. Brasília, 1979. 364 p., no capítulo 2.4 O Esvaziamento Econômico da Guanabara.
} 
caráter extremamente dinâmico e do impulso desenvolvimentista, locacionalmente concentrador, do Governo Kubitschek. Segundo, o cancelamento abrupto das atividades de capital nacional, item importante na formação do setor terciário do Rio de Janeiro. Pode-se acrescentar a estas duas causas estruturais os problemas específicos da região, que limitavam o desenvolvimento econômico. De natureza administrativa, a incoerência entre a região de influência da área urbana do Rio de Janeiro e o sistema que a gerenciava, criavam barreiras institucionais que impediam a integração regional. De natureza física, a região apresentava um modelo de localização de atividades fortemente concentrador nas áreas centrais, estas servidas por uma infra-estrutura inadequada e cara. De natureza econômica, a inexistência de políticas de desenvolvimento, que possibilitassem incentivos à atividade industrial assim como proporcionassem alternativas de localização para essa atividade, dificultaram o desenvolvimento do setor secundário e conseqüentemente do setor terciário.

Pode-se avaliar melhor o significado do fenômeno do esvaziamento econômico da região através da evolução da renda interna do Município durante o período 1950-1969, Tabela 2 Evolução da Renda Interna do Município do Rio de Janeiro 1950-1969. Seu crescimento é significativamente menor do que o do conjunto do país, especialmente no período da construção da nova capital. A renda interna per capita também experimentava um crescimento relativo menor do que o país como um todo, mantendo-se, no entanto, sempre em nível bastante superior em valor absoluto. No período 1960-1969, a renda per capita do brasileiro passou de US\$ 166 para US\$ 281 enquanto a do carioca variou de US\$ 438 para US\$ $694^{13}$. A renda, embora alta em valor absoluto, era mal distribuída entre a população. Baseada na pesquisa de despesas familiares, os 5\% mais ricos da população municipal

\footnotetext{
${ }^{13}$ Segundo PREFEITURA DA CIDADE DO RIO DE JANEIRO, Secretaria Municipal de Planejamento e Coordenação Geral. PUB Rio, Plano Urbanístico Básico da Cidade do Rio de Janeiro. Rio de Janeiro, jun. 1977. 280 p.
} 
acumulavam 32\% da renda total e a metade mais pobre da população acumulava apenas cerca de $16 \%$ da renda no ano de 1975, como se pode apreender da Tabela 3- Distribuição da Renda na RMRJ - 1975 em Porcentagem Acumulada.

Tabela 2 - Evolução da Renda Interna do Município do Rio de Janeiro 1950-1969

\begin{tabular}{c|cc|cc}
\hline \multirow{2}{*}{ ANO } & \multicolumn{2}{|c|}{ BRASIL } & \multicolumn{2}{c}{ CIDADE DO RIO DE JANEIRO } \\
ÍNDICE & VARIAÇÃO \\
\hline 1950 & 100 & $38,0 \%$ & 100 & $30,0 \%$ \\
1955 & 138 & $33,0 \%$ & 130 & $17,5 \%$ \\
1960 & 184 & $25,5 \%$ & 153 & $19,6 \%$ \\
1965 & 231 & $24,6 \%$ & 183 & $20,7 \%$ \\
1969 & 288 & & 221 & \\
\hline
\end{tabular}

Fonte: Plano Urbanístico Básico da Cidade do Rio de Janeiro, 1977.

Tabela 3 - Distribuição da Renda na RMRJ - 1975 em Porcentagem Acumulada

$\begin{array}{lccccccccc}\text { POPULAÇÃO ACUMULADA } & 1.6 & 9.1 & 28 & 46 & 62 & 72 & 86 & 95 & 100 \\ \text { RENDA ACUMULADA } & 0.1 & 1.3 & 6.7 & 15 & 24 & 33 & 48 & 68 & 100\end{array}$

Fonte: Darbèra e Marchand - “Les Déterminants de la Politique Locale des Transports Urbains”.

A porcentagem da população economicamente ativa cujo salário era inferior a 2,5 vezes o salário mínimo em 1970 correspondia a 80\% para a Região Metropolitana do Rio de Janeiro RMRJ, valor coincidente para o Brasil como um todo.

A composição da renda por setor econômico no Município do Rio de Janeiro para os anos 1950 a 1965, de acordo com a Tabela 4 - Evolução da Composição da Renda por Setor Econômico do Município do Rio de Janeiro - MRJ e do Brasil, 1950 - 1965, quando comparada com o total da nação, nos leva a concluir sobre a forte vocação terciária do 
município à epoca, que gerava em 1965, no setor de comércio e serviços, 80,3\% de sua renda contra 53,3\% gerados pelo Brasil.

Tabela 4 - Evolução da Composição da Renda por Setor Econômico do Município do Rio de Janeiro (MRJ) e do Brasil, 1950 - 1965

\begin{tabular}{|c|c|c|c|c|c|c|c|c|}
\hline & \multicolumn{2}{|c|}{1950} & \multicolumn{2}{|c|}{1955} & \multicolumn{2}{|c|}{1960} & \multicolumn{2}{|c|}{1965} \\
\hline & $\begin{array}{r}\text { Brasil } \\
\% \\
\end{array}$ & $\begin{array}{r}\text { MRJ } \\
\% \\
\end{array}$ & $\begin{array}{r}\text { Brasil } \\
\% \\
\end{array}$ & $\begin{array}{r}\text { MRJ } \\
\% \\
\end{array}$ & $\begin{array}{r}\text { Brasil } \\
\% \\
\end{array}$ & $\begin{array}{r}\text { MRJ } \\
\% \\
\end{array}$ & $\begin{array}{r}\text { Brasil } \\
\% \\
\end{array}$ & $\begin{array}{r}\text { MRJ } \\
\% \\
\end{array}$ \\
\hline Agricultura & 26,6 & 2,1 & 25,1 & 1,1 & 22,7 & 1,2 & 22,2 & 1,2 \\
\hline Indústria & 23,5 & 21,4 & 24,4 & 21,8 & 25,2 & 17,3 & 24,4 & 18,5 \\
\hline Comércio e Serviços & 49,9 & 76,6 & 50,5 & 77,1 & 52,3 & 81,5 & 53,3 & 80,3 \\
\hline Comércio & 18,0 & 21,8 & 16,3 & 19,2 & 15,1 & 14,9 & 13,5 & 14,2 \\
\hline Intermed. Financeira & 5,1 & 8,6 & 5,8 & 9,4 & 6,8 & 12,8 & 8,5 & 14,7 \\
\hline Transportes & 6,6 & 10,0 & 6,3 & 9,7 & 6,5 & 10,1 & 6,6 & 11,5 \\
\hline Governo & 7,5 & 17,5 & 7,1 & 15,9 & 8,2 & 20,1 & 9,5 & 20,0 \\
\hline Aluguéis & 3,8 & 5,4 & 3,5 & 7,2 & 3,0 & 6,4 & 1,9 & 4,3 \\
\hline Outros & 8,9 & 13,3 & 11,7 & 15,7 & 12,8 & 17,2 & 13,4 & 15,6 \\
\hline
\end{tabular}

Fonte: Plano Urbanístico Básico - PUB, 1977.

Paralelamente à predominância do setor terciário, pode-se observar que o município tinha uma estrutura agrícola e industrial mais fraca do que o país como um todo. Dentro do setor terciário, predominava a renda gerada pelas atividades de governo, que permaneceram elevadas mesmo cinco anos depois da mudança da capital para Brasília, o que reduz, no curto prazo, o peso da argumentação sobre a importância da mudança de funções administrativas no fenômeno do esvaziamento econômico. As atividades de comércio e das intermediações financeiras também eram especialmente expressivas no município nesse período. Quando se analisa a evolução de cada setor econômico, percebe-se um decréscimo na participação relativa da atividade industrial. No setor terciário, os itens Governo e Intermediações Financeiras eram as atividades que apresentavam incrementos positivos, caracterizando o município como centro financeiro nacional e concentrador de atividades administrativas nacionais no período. 
Fechando a década de 1970, no que se refere à ocupação da mão-de-obra, ver Tabela 5 - Mãode-obra Ocupada em 1980 por Setor de Atividade no Estado do Rio de Janeiro - ERJ, Região Metropolitana do Rio de Janeiro - RMRJ e Município do Rio de Janeiro - MRJ, a maior parte da população economicamente ativa da RMRJ, 69,6\% do total, estava empregada no setor terciário e no município era 73,5\% da PEA nesse setor. Apenas 0,5\% da PEA do município, 1,1\% da RMRJ e 4,7\% do ERJ estavam ocupadas no setor primário, embora o estado possuísse vasta extensão territorial passível de ocupação agrícola.

Tabela 5 - Mão-de-Obra Ocupada em 1980 por Setor de Atividade no Estado do Rio de Janeiro (ERJ), Região Metropolitana do Rio de Janeiro (RMRJ) e Município do Rio de Janeiro (MRJ)

\begin{tabular}{|c|c|c|c|c|c|c|}
\hline \multirow{2}{*}{ Setor de Atividade } & \multicolumn{2}{|c|}{ ERJ } & \multicolumn{2}{|c|}{ RMRJ } & \multicolumn{2}{|c|}{ MRJ } \\
\hline & Mão-de-obra & $\%$ Total & Mão-de-obra & $\%$ Total & Mão-de-obra & $\%$ Total \\
\hline Agropecuária, extração veg. e pesca & 195.580 & 4,7 & 29.242 & 1,1 & 9.123 & 0,5 \\
\hline Indústria & 1.241 .157 & 29,6 & 999.918 & 29,3 & 538.356 & 26,2 \\
\hline Transformação & 764.319 & & 634.216 & & 355.729 & \\
\hline Construção & 399.979 & & 304.493 & & 144.327 & \\
\hline Outras & 76.859 & & 61.209 & & 38.300 & \\
\hline Comércio e serviços & 2.755 .915 & 65,7 & 2.376 .447 & 69,6 & 1.505 .008 & 73,3 \\
\hline Comércio de mercadorias & 489.406 & & 419.109 & & 247.051 & \\
\hline Transportes e comunicação & 290.070 & & 252.128 & & 155.097 & \\
\hline Prestação de serviços & 1.061 .046 & & 905.260 & & 548.342 & \\
\hline Atividades sociais & 431.481 & & 365.830 & & 254.190 & \\
\hline Administração pública & 289.234 & & 256.509 & & 171.572 & \\
\hline Outros & 194.678 & & 177.611 & & 128.756 & \\
\hline Total & 4.192 .652 & 100,0 & 3.415 .607 & 100,0 & 2.052 .487 & 100,0 \\
\hline
\end{tabular}

A RMRJ era o segundo parque industrial do país, embora com um desempenho muito aquém do paulista, concentrando em 1980, 10\% da renda interna brasileira. Predominavam no valor da transformação industrial, os setores mais dinâmicos como: químico, editorial e gráfico, mantendo-se significativa, no entanto, a indústria de produtos alimentícios. Nota-se grande expansão de indústrias de construção naval. A construção civil era ramo significativo. 
Espacialmente, as indústrias mais tradicionais predominavam em áreas centrais como Méier, São Cristóvão, Centro e Portuária, de onde se deslocaram as indústrias mais dinâmicas, ao longo dos principais eixos de transporte rodoviário: avenida Brasil, rodovia Presidente Dutra, rodovia Presidente Washington Luiz, nas direções de Jacarepaguá, Bonsucesso e Engenho Novo. O Estado do Rio de Janeiro, através do I PLAN-RIO, aprovado na forma de lei em 1976, estabeleceu uma política de desenvolvimento industrial que visava dinamizar a indústria de base e estimular investimentos. Outro objetivo era relocalizar a indústria na periferia, definindo distritos industriais - Santa Cruz, Fazenda Botafogo, Palmares, Paciência, Caxias, Nova Iguaçu, Campo Grande e Itaguaí.

Era predominante a localização de indústrias dentro da área do município, em número de empregos e em valor da transformação industrial, concentrando 60,1\% das indústrias da RMRJ. O município que ocupava o segundo lugar em concentração industrial (expressa em valor da transformação industrial) era Duque de Caxias e em número de empregos era Nova Iguaçu com 12,8\% do total do Estado. Internamente ao Município do Rio de Janeiro, Bangu era o principal centro de empregos no setor secundário, sendo o segundo bairro em população, examinar Tabela 6 - População residente e mão-de-obra na indústria em alguns distritos do MRJ, 1980. As perspectivas de desenvolvimento do setor industrial na região apontavam na direção de uma especialização da indústria farmacêutica, material elétrico, eletrônico e acústico, química e naval. 
Tabela 6 - População Residente e Mão-de-Obra na Indústria em Alguns Distritos do MRJ, 1980

\begin{tabular}{l|c|c}
\hline & Mão-de-obra na indústria & População do distrito \\
\hline BANGU & 57.744 & $530.238\left(1^{\circ}\right)$ \\
MEYER & 55.415 & $411.641\left(2^{\circ}\right)$ \\
PENHA & 39.321 & $315.674\left(6^{\circ}\right)$ \\
RAMOS & 32.655 & $255.201\left(9^{\circ}\right)$ \\
CENTRO & 5.187 & 55.108 \\
PORTUÁRIA & 4.573 & 46.113 \\
\hline
\end{tabular}

Fonte: IBGE - Censo Demográfico RJ 1980.

O Município do Rio de Janeiro concentrava serviços de abrangência nacional, com recursos humanos altamente qualificados. Era ainda o segundo porto nacional cujas funções, entretanto, tendiam a se restringir ao âmbito regional. Manteve-se como grande centro atacadista e distribuidor nacional e, conseqüentemente, como grande centro financeiro, concentrando recursos para movimentação de produtos e abrigando as principais entidades financeiras do governo e as maiores empresas privadas. No âmbito do setor terciário, as atividades que congregavam maior número de empregados em 1980 eram a prestação de serviços, as atividades sociais e o comércio de mercadorias, de acordo com a Tabela 5 acima.

O item Administração Pública participava com 11,4\% dos empregos, valor que não refletia, entretanto, o número de empregos reais na função pública, visto que, agregado aos outros itens como Transportes e Comunicações, Atividades Sociais e Prestação de Serviços, por exemplo, estão os empregos gerados por empresas públicas que atuam nessas áreas, de acordo com a metodologia IBGE. Os empregos gerados pelos grandes bancos estatais, pelo ensino público, pelas empresas municipais de transporte coletivo, por exemplo, também não estão contidos no item Administração Pública. Constata-se a presença maciça do setor público na formação dos salários que remuneravam serviços e na formação do capital fixo, através de importantes investimentos em infra-estrutura urbana: o Metrô, o Aeroporto Internacional, a Ponte Rio- 
Niterói, o Programa de Modernização Ferroviária etc., implantados simultaneamente. O Município do Rio de Janeiro era e ainda é também o grande centro turístico brasileiro, sendo a principal porta de entrada do país aonde desembarcavam cerca de 75\% dos turistas estrangeiros, grande parte tendo a cidade do Rio de Janeiro como destinação única. Da mesma forma, era e ainda é importante centro cultural, mantendo grandes e conceituadas universidades ${ }^{14}$.

\subsection{Evolução da ocupação urbana}

A área que constitui a Região Metropolitana do Rio de Janeiro é de topografia acidentada, resultado do encontro de uma cadeia de montanhas com o mar; a Serra da Carioca que, próxima ao litoral se eleva nos maciços da Pedra Branca, Carioca-Tijuca e Niterói. De beleza paisagística deslumbrante, proporcionada por elevações abruptas de granito e áreas de vegetação abundante, a região apresenta uma acessibilidade difícil, que necessita de grandes investimentos na infra-estrutura de ligação entre os sítios, outrora isolados pelas montanhas, e o mar. Paralela à Serra da Carioca e mais interiorizada com relação à Serra do Mar, a Serra de Madureira cria um relevo rico de elevações, vales e baixadas que, por sua vez, delineiam zonas inundáveis e mangues de difícil ocupação urbana.

Ao longo do litoral extremamente recortado, a ocupação se deu na parte interna da Baia de Guanabara nas áreas conhecidas como Praça XV, Praça Mauá e Ilha de Villegaignon. A partir do núcleo central, a ocupação urbana tomou inicialmente o sentido Oeste formando os bairros de São Cristóvão e Quinta da Boa Vista, conforme pode ser observado na Ilustração 5 Cidade do Rio de Janeiro - Ocupação Urbana e Direção da Expansão no início do século XIX.

\footnotetext{
${ }^{14}$ PREFEITURA DA CIDADE DO RIO DE JANEIRO, Secretaria Municipal de Planejamento e Coordenação Geral. PUB Rio, Plano Urbanístico Básico da Cidade do Rio de Janeiro. Rio de Janeiro, Jun. 1977. 280 p.
} 
A ilustração mostra também a linha da orla marítima no ano de 1967, construída através de sucessivos desmontes de morros e aterramentos que foram sendo feitos no último século, transformando fortemente o perfil original.

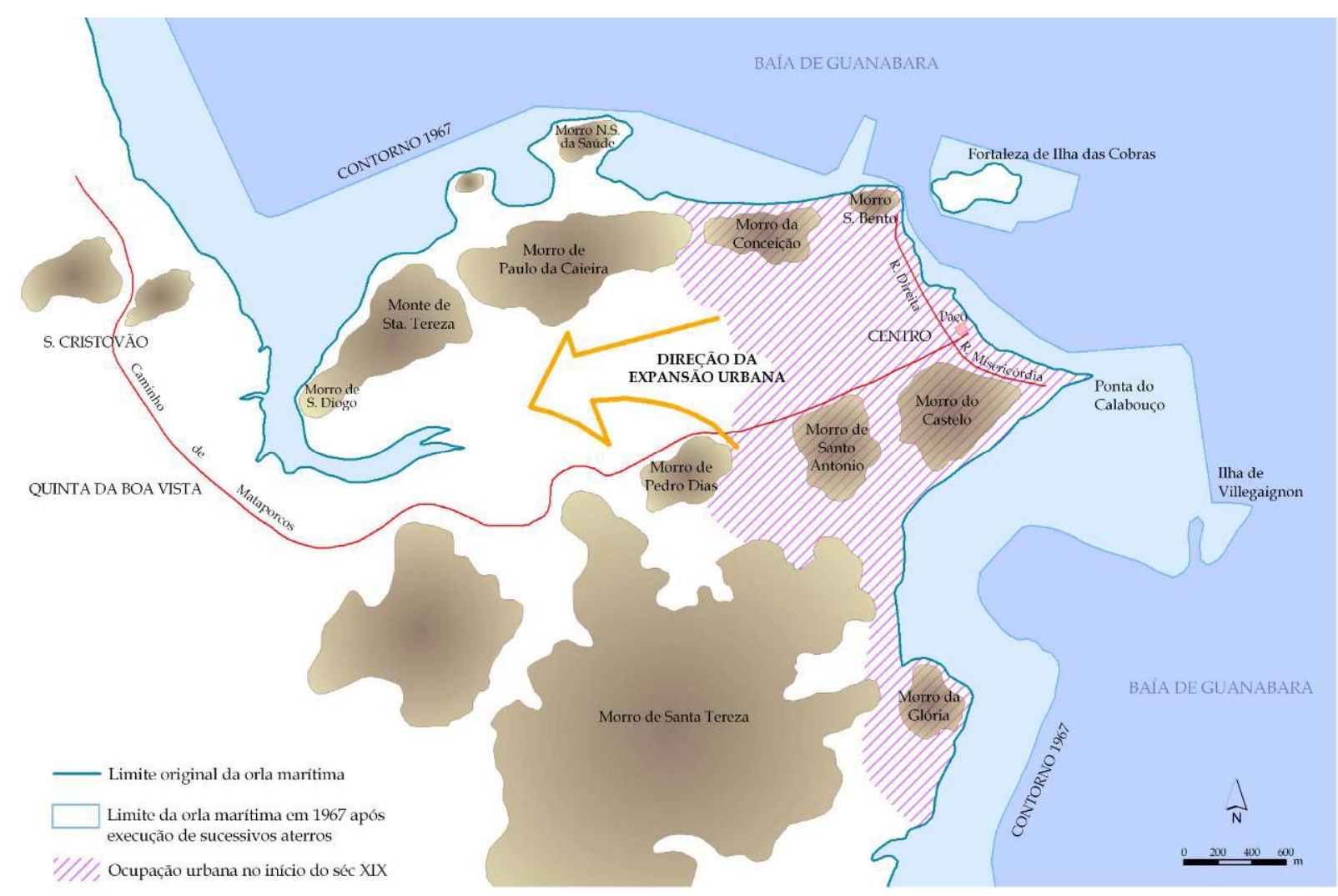

Referência: SCHNOOR, J. A Harmonia do Desenvolvimento Urbano em Função da Rede de Transporte Coletivo de Massa. Rio de Janeiro: BNH, 1975. 127 p.

\section{Ilustração 5 - Cidade do Rio de Janeiro - Ocupação Urbana e Direção da Expansão no início do século XIX}

Ainda enquanto capital do Império, a cidade do Rio de Janeiro foi alvo de ações de planejamento, através do primeiro plano elaborado para a cidade em 1875 pela Comissão de Melhoramentos cujas propostas seriam, em grande parte, realizadas nos anos iniciais da República. Várias intervenções de grandes proporções foram feitas no centro do Rio de Janeiro, de iniciativa e responsabilidade dos governos federal e local e exigiram um grande volume de recursos. 
Essas grandes intervenções federais se constituíram no primeiro grande conjunto de obras e se iniciaram com a construção do porto, primeira grande obra da República, entre 1900 e 1910, que removeu completamente o Morro do Senado ${ }^{15}$ utilizando o solo resultante para aterro da baía adjacente, para a construção do cais do porto e das avenidas Rodrigues Alves e Francisco Bicalho, dando início a um conjunto de grandes obras com dupla finalidade, de sanear e higienizar a cidade e também modernizá-la e embelezá-la já que capital da nação. Cabe lembrar que, em 1900, o Distrito Federal contava com quase 700.000 habitantes. A região estava sujeita a duas frentes de decisão e aporte de recursos, federal e municipal. Foi de grande relevância a atuação do Prefeito Francisco Pereira Passos em consonância com o Presidente Rodrigues Alves e o grande volume de recursos nacionais para a realização das obras, conhecidas como Reforma Pereira Passos, considerada como o elemento transformador da cidade construída nas épocas colonial e imperial na cidade dos dias de hoje, de forte influência francesa a partir do Barão Haussman. Grande parte dessas intervenções havia sido proposta no Plano de Melhoramentos de 1875, estudo do qual Pereira Passos participou ativamente. Para a execução das obras do porto, o governo federal celebrou empréstimos junto a bancos ingleses em quantia equivalente à metade da receita da União ${ }^{16}$.

À municipalidade couberam as obras de melhorias e aberturas de ligações viárias do Centro com a Zona Sul - avenida Beira-Mar - e com a Zona Norte - avenidas Mem de Sá e Salvador de Sá -, bem como obras de saneamento, canalização dos rios Carioca e Maracanã, e

\footnotetext{
${ }^{15} \mathrm{O}$ início do desmonte do Morro do Senado se deu ainda na administração do prefeito João Felipe quando começou o aterro do mangue entre o continente e a Ilha das Moças em São Cristóvão e a construção do canal, com o transporte diário de terra de cerca de $125.000 \mathrm{~m}^{3}$, pela Empresa Industrial de Melhoramentos do Brasil, cujos diretores eram os engenheiros Paulo de Frontin e Carlos Sampaio, de acordo com REIS, J. de O. O Rio de Janeiro e seus Prefeitos: Evolução Urbanística da Cidade. Prefeitura da Cidade do Rio de Janeiro, Rio de Janeiro, 1977. 167 p., página 10. Nessa região seria construído o novo porto do Rio de Janeiro.

${ }^{16}$ Segundo a pesquisa realizada em oito cidades brasileiras, dentre elas o Rio de Janeiro, sobre planos e intervenções urbanas de grande porte compilada em LEME, M. C. (Org.) Urbanismo no Brasil - 1895-1965. São Paulo: FUPAM, Studio Nobel, 1999, 599 p.
} 
embelezamento com a implantação de várias praças como o Passeio Público, praça XV, praça São Salvador, praça Tiradentes e largo da Lapa, sempre com o aval financeiro e de decisão da esfera federal. Várias ruas na área central da cidade foram alargadas, dentre elas, as ruas da Carioca, da Assembléia e Uruguaiana, o que exigiu um grande volume de desapropriações e retirada da população. O prefeito que sucedeu Pereira Passos, Francisco Marcelino Sousa Aguiar, fez novos empréstimos no exterior para sanar a situação financeira do Distrito Federal devido ao volume de obras realizado.

Também de iniciativa federal, sob a administração direta do Ministério de Viação e Obras Públicas, seguiu-se ao porto a abertura da avenida Central, atual avenida Rio Branco, inaugurada em 1905, que rasgou uma larga faixa de tecido urbano, para implantação de avenida ligando o Cais do Porto à avenida Beira-Mar, entre o Morro do Castelo e o Morro de Santo Antonio, gerando espaços para construções voltadas para o comércio e serviços. A avenida Central mudou os hábitos da cidade, reunindo as melhores lojas, as sedes dos jornais, grandes companhias, clubes, hotéis e vários prédios públicos que permanecem até os dias de hoje, como a Escola de Belas Artes, a Biblioteca Nacional e o Teatro Municipal. As áreas desapropriadas excedentes à largura da avenida, extremamente valorizadas por essas obras, foram comercializadas, cobrindo parte das despesas do Governo Federal ${ }^{17}$.

Foi só a partir do século XIX que as classes mais ricas buscaram a orla marítima, sendo seguidas nessa nova direção Sul e Sudoeste, já no século XX, pela crescente classe média surgida com a economia industrial, ver Ilustração 6 - Cidade do Rio de Janeiro - Direção da

\footnotetext{
${ }^{17}$ Nos anos 1970, à época da implantação do trecho inicial do Metrô-RJ, a idéia de apropriação financeira da melhoria realizada pelo poder público veio a gerar polêmica com relação à comercialização das áreas excedentes da desapropriação. Pode-se observar que no caso da avenida Central, essa idéia foi concretizada cerca de 70 anos antes da iniciativa da Companhia do Metrô-RJ.
} 
Expansão Urbana em meados do século XX. Grandes investimentos em infra-estrutura eram necessários nessa mudança de direção, com a ocupação agora ao longo das praias, como a construção de túneis para alcançar sítios mais isolados. Foram as classes mais ricas aquelas que se apropriaram dos resultados desses investimentos, deixando então as áreas mais interiorizadas às classes mais pobres, que acompanharam os principais eixos de transporte ferroviário, na direção N e NO, num processo de fragmentação da cidade, entre ricos e pobres que se acentuaria de forma significativa e irreversível a partir de então.

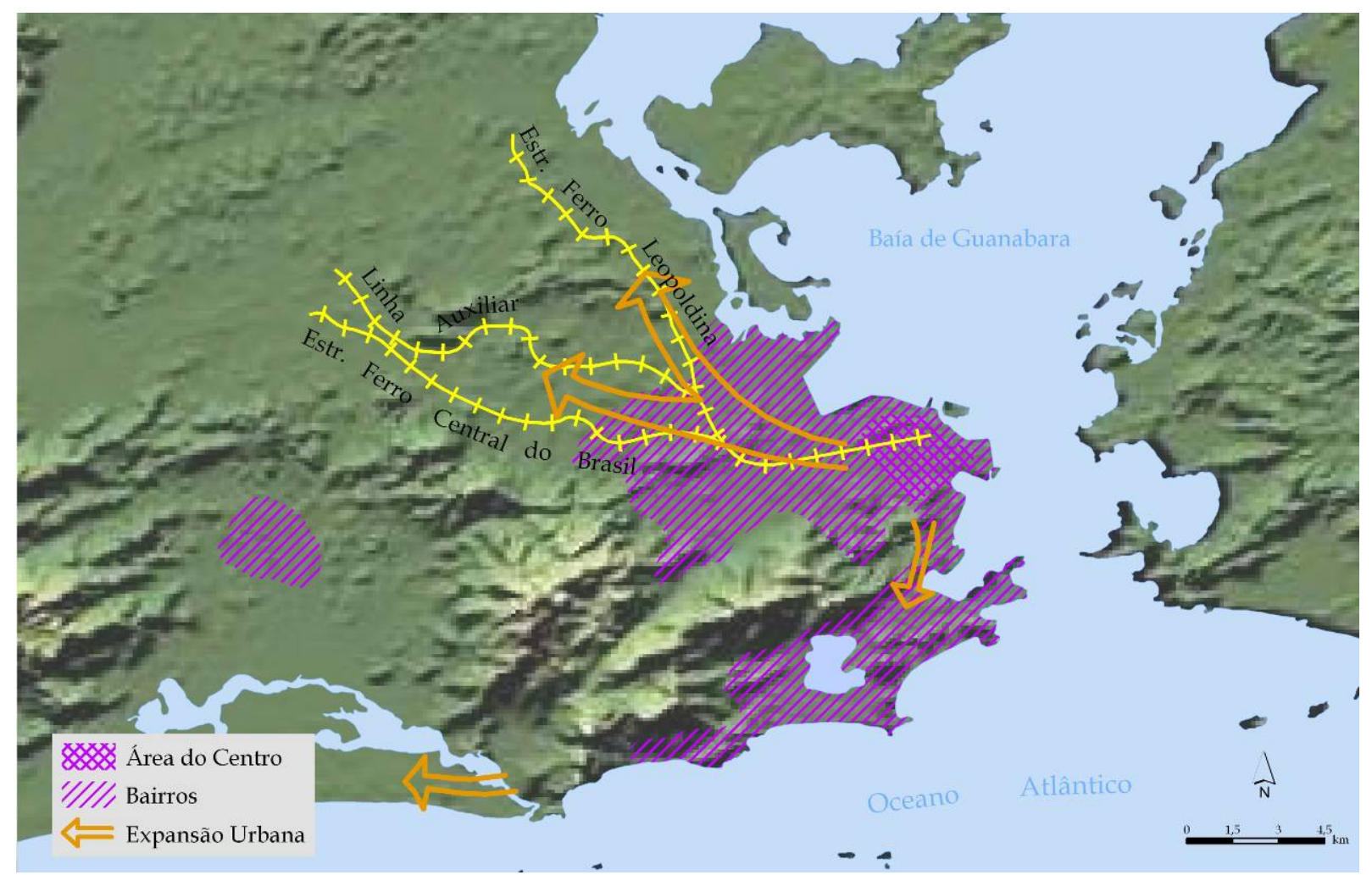

Referência: BARAT, J. Estrutura Metropolitana e Sistema de Transportes: Estudo de Caso do Rio de Janeiro. IPEA - Série Monográfica, no. 20. Rio de Janeiro, 1975. 292 p.

\section{Ilustração 6 - Cidade do Rio de Janeiro - Direção da Expansão Urbana em meados do século XX}

No final do século XIX e início do século XX, a expansão ao longo da orla marítima se intensificou com a perfuração do Túnel Velho, que abriu a área de Copacabana à ocupação urbana, acompanhada pela primeira linha de bondes para Copacabana, inaugurada na mesma 
data, 15 de maio de 1892. Durante a administração do Prefeito Pereira Passos, foi aprovado o projeto de alinhamento da avenida Atlântica, obra de vulto, para a qual foi necessária a construção de muros e aterros.

As administrações que sucederam Pereira Passos prosseguiram nas obras de melhoria e calçamento do sistema viário e outras obras significativas, dentre elas: túneis, avenida Niemeyer, cais da Urca, avenida Delfim Moreira e também obras nos subúrbios. Mas foi no início dos anos 1920, na administração Carlos Sampaio, que se iniciou um segundo conjunto de obras de grande envergadura e certamente de grandes custos. O desmonte do Morro do Castelo $^{18}$ para a implantação do projeto da exposição comemorativa dos 100 anos da independência, através de desmonte hidráulico com aterramento da enseada da Glória, que exigiu um grande volume de desapropriações - cerca de 470 prédios foram demolidos - e de onde 3 milhões de $\mathrm{m}^{3}$ foram retirados ${ }^{19}$. A população atingida teve que ser transferida e abrigada em outro local e um importante hospital infantil foi relocado. Complementarmente às obras da exposição de 1922, foi construída a avenida de contorno do Morro da Viúva, uma jazida de granito de onde se extraiu grande parte do material para enrocamento, base para receber o aterro da área para a exposição. Foram também dessa época as obras de saneamento da Lagoa Rodrigo de Freitas, projeto de Saturnino de Brito associado a projeto de loteamento residencial e a construção da av. Maracanã.

A administração do prefeito Antonio Prado Jr., 1926-1930, trouxe para a cidade um esforço de planejamento dos mais importantes; foi elaborado o primeiro plano de conjunto para a

\footnotetext{
${ }^{18}$ Conhecido também como Monte da Sé Velha, Morro do Descanso ou de São Sebastião ou ainda como Alto da Cidade.

${ }^{19}$ É interessante lembrar que Carlos César de Oliveira Sampaio foi o engenheiro responsável pelas obras do desmonte do Morro do Senado, 20 anos antes, para a construção do porto.
} 
cidade, denominado “Cidade do Rio de Janeiro - Remodelação, Extensão e Embelezamento 1926-1930”, o Plano Agache ${ }^{20}$, que serviria em parte de direcionamento para as ações sobre a cidade por pelo menos mais três ou quatro décadas. Dentre as principais indicações do plano esteve a definição do projeto da Esplanada do Castelo, que seria o cartão de visitas da Capital da República, a primeira proposta de um sistema de transportes coletivos subterrâneo, o metrô, e de um sistema adequado de ligações ferroviárias para os subúrbios, bem como transporte rápido por barcas cruzando a baía da Guanabara.

Data também dessa época o estudo feito por Le Corbusier para o Rio de Janeiro. Trata-se de um grande viaduto habitado, mantendo a cidade existente e projetando uma nova cidade, alta, que não teria interferência com a existente. Propôs uma enorme via expressa aérea - um viaduto com cerca de 15 metros de altura para o transporte coletivo (metrô ou bondes) - e, sob a mesma, a criação de lajes de concreto (terrenos artificiais) para habitação e comércio ${ }^{21}$.

A primeira fase da industrialização carioca localizou predominantemente no Centro a maior parte das atividades: a produção de bens de consumo imediato ao lado das funções de comércio atacadista e distribuidor geradas pelo porto. A expansão periférica era ainda eminentemente residencial e estabelecida em consonância com as decisões das empresas concessionárias dos serviços de bondes que, muitas vezes, criavam os novos bairros. A partir da década de 1930, a indústria começou a se dirigir para Norte e Oeste na direção dos

\footnotetext{
${ }^{20}$ O Plano Agache tinha como objetivo considerar o conjunto dos diferentes problemas da cidade, orientar o seu crescimento e expansão física e organizá-la administrativamente para as suas necessidades futuras. É muito mais completo do que os planos elaborados para outras cidades brasileiras à mesma época. Continha um histórico da formação da cidade, uma leitura topográfica do sítio, a evolução da ocupação urbana, os elementos funcionais (dentre eles um sistema de parques urbanos), a ossatura da cidade (sistema viário) e os grandes problemas sanitários, com previsão para os sistemas de infra-estrutura. Propunha a criação de um órgão permanente de planejamento da cidade e de formulação de legislação urbanística.

${ }^{21}$ O desenho resultante está baseado nos preceitos do Movimento Modernista, inspirado na Carta de Atenas e nos textos de Le Corbusier Penser la Ville, concepção repetida para a cidade de Alger.
} 
principais eixos de transporte já estabelecidos com as ferrovias. Coincidiu com o início da favelização dos morros ${ }^{22}$ e das áreas de baixadas e várzeas, num processo de urbanização marginal por uma população de baixíssimo poder aquisitivo, que buscava o mercado de trabalho nos serviços, primeiramente do Centro e depois da Zona Sul.

Nessa época, naquela que viria a ser a atual Região Metropolitana do Rio de Janeiro, localizavam-se núcleos urbanos isolados como Caxias, Nova Iguaçu, Nilópolis, São João do Meriti, Itaguaí, Paracambi e muitos outros surgidos a partir dos pontos de parada dos trens, que, no processo de metropolização da cidade do Rio de Janeiro, viriam a se fundir numa malha urbana única.

O Prefeito Henrique Dodsworth, gestão de 1937 a 1945, inaugurou o terceiro grande ciclo de obras na cidade, sendo considerado o prefeito que, depois de Pereira Passos, conseguiu realizar um programa de obras grandioso, tendo a urbanização da Esplanada do Castelo e a implantação das avenidas Presidente Vargas e Brasil como seus exemplos mais significativos.

A urbanização da Esplanada do Castelo foi uma obra de grandes dimensões iniciada pelo menos duas décadas antes, no início dos anos 1920 pelo Prefeito Carlos Sampaio, e que, obedecendo a uma revisão substancial da proposta do Plano Agache, foi finalmente implantada, com a abertura de novas vias e com a construção de novas edificações de grande porte. Ver Ilustração 7 - Novas áreas de expansão no centro da cidade com o desmonte do Morro do Castelo, foto obtida em “Os três Centros do Rio”, de Rachel Sisson. A abertura da avenida Presidente Vargas

\footnotetext{
${ }^{22}$ Já se falava em favela em 1886, mas elas aumentaram consideravelmente no final da $1^{\mathrm{a}}$ metade do século XX. Ver FUNDAÇÃO IBGE. Sinopse Preliminar do Censo Demográfico: IX Recenseamento Geral do Brasil 1980. Secretaria de Planejamento da Presidência da República, v 1, tomo 1, no. 1.
} 
seguiu o modelo da avenida Central ao destruir quadras inteiras de cortiços e habitação de aluguel, demolindo também várias igrejas e o Paço Municipal. O projeto estabeleceu um novo padrão de parcelamento do solo e instituiu a obrigação de construção de galerias para pedestres - parte das calçadas cobertas por marquises ao longo da avenida.

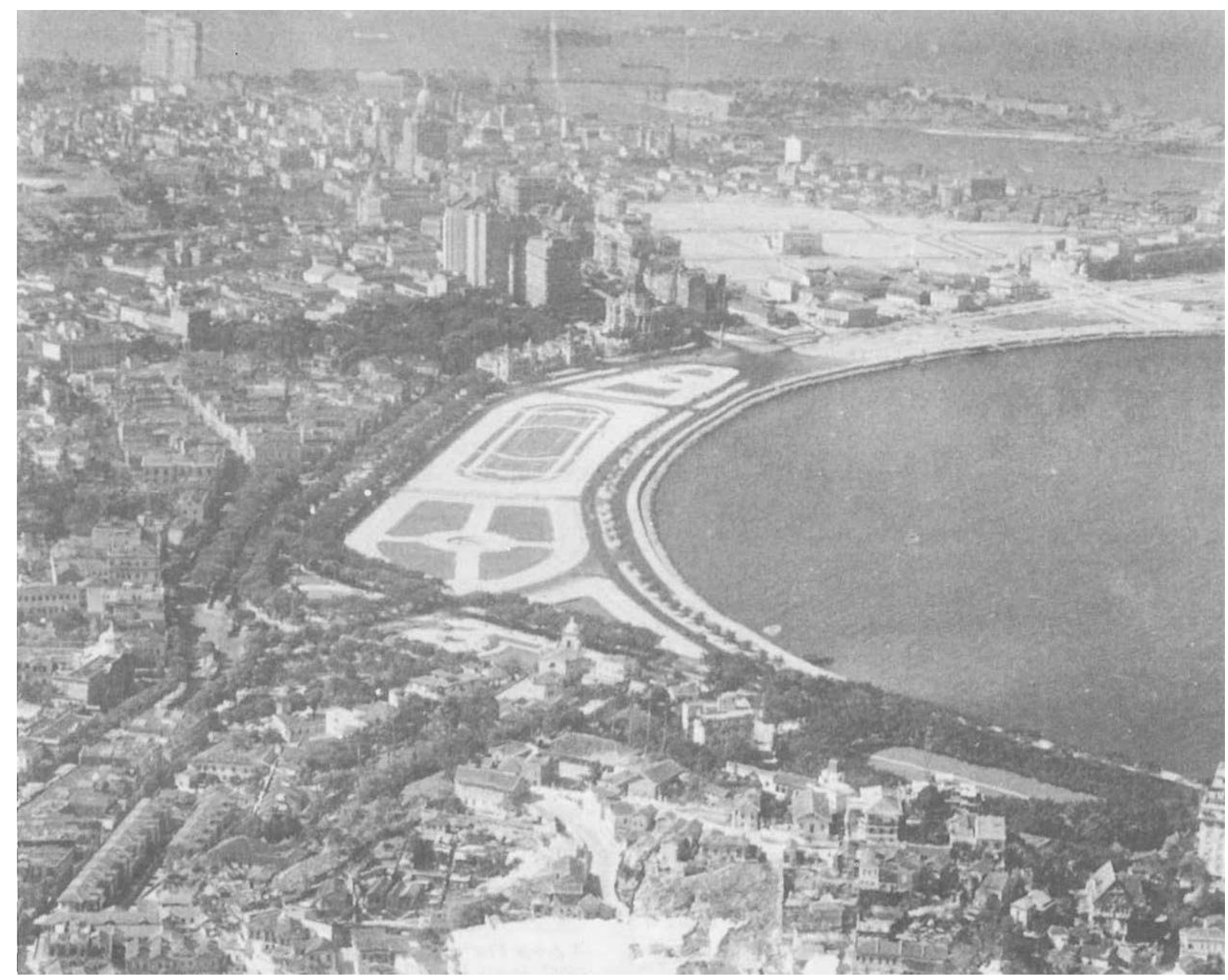

Fonte: SISSON, R. Os três Centros do Rio. Revista Municipal de Engenharia, Prefeitura da Cidade do Rio de Janeiro, v XXXIX, p. 55-71, out./dez. 1983.

\section{Ilustração 7 - Novas Áreas de Expansão no Centro da Cidade com o desmonte do Morro do Castelo}

Embora a abertura da avenida Presidente Vargas fosse uma idéia antiga - meados do século XIX com o Barão de Mauá - foi uma conjunção de interesses, municipais e federais, que possibilitou sua viabilização. Cabe observar que, de acordo com a análise pormenorizada feita por José de Oliveira Reis em O Rio de Janeiro e seus Prefeitos - Evolução Urbanística da Cidade, as 
obras do Governo Federal na cidade não levavam em conta as diretrizes do planejamento municipal, de forma que a Comissão do $\operatorname{Plano}^{23}$ tinha que adaptar sua programação às realizações do Governo Federal, que dominava a região. Constam do quadro de realizações do Governo Federal nessa época a eletrificação da Estrada de Ferro Central do Brasil na direção dos subúrbios e o Aeroporto Santos Dumont, que exigiu um volume de aterro de grandes dimensões, e cuja localização condicionou ainda mais os fluxos viários para a região central.

Ainda dentre as realizações do Prefeito Henrique Dodsworth destacam-se a construção da avenida Brasil, sobre aterro, com o objetivo de deslocar a parte inicial das rodovias e criar terrenos para indústrias, as melhorias na avenida Tijuca (estrada turística), a remodelação de acessos e áreas de convívio na Floresta da Tijuca, a duplicação do Túnel do Leme, a urbanização da Praia Vermelha, o Corte do Cantagalo, o Jardim de Allah, o Parque da Gávea, o Jardim Zoológico e a remodelação e o restauro do Alto do Corcovado, todas de grande impacto na cidade, especialmente no que se refere à imagem da Capital.

De maneira geral, as administrações municipais do Rio de Janeiro lograram alternativas de financiamento de obras públicas bastante singulares, quando comparadas com outras grandes cidades brasileiras ${ }^{24}$. Além dos aportes diretos do Governo Federal, muitas vezes através de endividamentos do país no mercado externo, contou com autorizações legislativas para endividamento municipal com bancos estrangeiros e praticou expedientes

\footnotetext{
${ }^{23}$ Grupo de planejamento de caráter consultivo recomendado como uma das medidas institucionais do Plano Agache e instituído pelo interventor Adolfo Bergamini através de decreto municipal de 1931.

${ }^{24}$ Esta análise foi baseada nos dados brutos constantes da publicação já citada REIS, J. de O. O Rio de Janeiro e seus Prefeitos: Evolução Urbanística da Cidade. Prefeitura da Cidade do Rio de Janeiro, Rio de Janeiro, 1977. 167 p., que apresenta as realizações específicas de cada prefeito da cidade do Rio de Janeiro, muitas vezes acompanhadas de suas fontes de financiamento e acrescida dos comentários críticos constantes da apresentação de grandes obras urbanísticas no Brasil também em publicação já citada LEME, M. C. (Org.) Urbanismo no Brasil - 1895-1965. São Paulo: FUPAM, Studio Nobel, 1999, 599 p.
} 
inovadores de desapropriação de áreas a maior, internalizando para o poder público a valorização imobiliária dos terrenos resultantes das obras, de forma a financiá-las. Chegou mesmo a criar o instituto das “Obrigações Urbanísticas da Cidade do Rio de Janeiro” - letra hipotecária, garantida pelo Banco do Brasil -, através de decreto municipal de 1940, de forma a levantar empréstimo para a totalidade da obra de implantação da avenida Presidente Vargas. Este instituto de financiamento popular viria a ser utilizado por seus sucessores pelo menos até o governo de Carlos Lacerda. Dodsworth criou ainda o Banco da Prefeitura que viria mais tarde a se chamar Banco do Estado da Guanabara.

O Prefeito General Mendes de Morais, 1947 a 1952, construiu o Estádio do Maracanã, os túneis Catumbi-Laranjeiras, do Pasmado e o da rua Alice e a estrada Grajaú-Jacarepaguá, mas foi na administração do Prefeito Dulcídio Cardoso, 1952 a 1954, que se deu o grande impulso no desmonte do Morro de Santo Antonio, de forma a possibilitar a urbanização de vasta área central e o aterramento da orla até o Botafogo, consolidando a nova orla da enseada da Glória e do Botafogo tomando mais tarde os contornos do que é hoje o Aterro do Flamengo. Foi também Dulcídio Cardoso quem contratou os estudos preliminares do Metropolitano do Rio de Janeiro junto à empresa francesa Société Générale de Traction et d’Exploitations de Paris, ignorando a iniciativa da Companhia Light de construir o sistema metroviário em parceria com o poder público.

O prefeito seguinte, Alim Pedro, 1954 a 1955, elaborou projetos importantes para a cidade como a avenida Perimetral, que seria finalizada pelo Prefeito Negrão de Lima e o Túnel Rebouças, com 2.700m de extensão, mais tarde construído pelo Governador Carlos Lacerda. Iniciou as obras do sistema adutor de água do Guandu, fortemente ampliado na administração de Carlos Lacerda. 
Negrão de Lima, que governou a cidade como prefeito no período de 1956 a 1958, elaborou um documento denominado Plano de Realizações que deveria ser custeado pelo Fundo Especial de Obras Públicas ${ }^{25}$ - a ser obtido pela venda de terrenos urbanizados e pela arrecadação adicional sobre impostos gerais. Criou a SURSAN - Superintendência de Urbanização e Saneamento, que foi responsável por um conjunto de obras de grande expressão na cidade - avenidas, túneis, avenidas-canal de drenagem e obras de saneamento. Implantou o sistema de ônibus elétricos e criou a Companhia do Metro ${ }^{26}$.

Foi o Prefeito Sá Alvim, 1958-1960, último prefeito da cidade enquanto Capital Federal, que inaugurou parte da urbanização da área resultante do desmonte do Morro de Santo Antonio avenida Norte Sul e avenida Chile, onde seriam mais tarde construídos a Catedral Metropolitana e vários prédios para sediar empresas públicas de âmbito nacional, e completou as obras do aterro da Praia do Flamengo, avançando pelo Morro da Viúva até quase alcançar a Praia do Botafogo, e abriu uma pista de tráfego no Aterro do Flamengo. Também investiu na pista elevada da avenida Perimetral e na avenida Radial Oeste.

A cidade do Rio de Janeiro continuou crescendo e, em 1960, o Censo Demográfico feito pelo IBGE contabilizou 3.307.163 habitantes na área urbana. A região central, a Zona Sul e a parte da Zona Norte mais próxima do centro concentravam os recursos econômicos e financeiros através da moradia das classes mais favorecidas, a maior parte das atividades produtivas e uma completa infra-estrutura de serviços urbanos. Estes recursos eram mal distribuídos no sentido da periferia que se caracterizava pela moradia da população mais pobre, através da ocupação da

\footnotetext{
${ }^{25}$ Negrão de Lima também trabalhou no sentido de aumentar a arrecadação municipal oriunda de tributos com a campanha “Seu Talão vale Um Milhão” que premiava a exigência de notas fiscais.

${ }^{26}$ Observar que embora com projeto básico feito e com a Companhia do Metro criada, a construção do Metrô só se iniciou e de forma lenta 10 anos após, em 1968.
} 
Baixada Fluminense em grande parte com loteamentos ilegais, ocupações espontâneas - vastas regiões desservidas de infra-estrutura básica - que configuravam imensos bairros dormitórios. A periferia cresceu principalmente com o fluxo migratório advindo de outras cidades brasileiras e de áreas rurais, acrescido do fluxo de migrantes do núcleo central da região urbanizada, num fenômeno de expulsão de seus habitantes mais pobres, motivada, entre outros fatores, pela ação do poder público, especialmente através da política habitacional, dos programas viários e de renovação urbana. Remoções de população favelada, feitas pela CHISAM - Coordenação de Habitação de Interesse Social da Área do Grande Rio, chegaram a deslocar cerca de 90.000 pessoas entre 1965 e 1975, para conjuntos habitacionais distantes.

A cidade ocupava então as áreas urbanizáveis do centro e da zona sul - de maior poder aquisitivo - e as áreas de difícil urbanização destas mesmas zonas, com uma população bastante pobre vivendo em condições sub-humanas nas favelas. Compreendia a Zona Norte, isolada pela Serra da Carioca, com uma classe média numerosa e a área da Baixada Fluminense, a grande massa de pobreza, conurbada com municípios vizinhos. Os elementos de infra-estrutura geradores desse processo de metropolização eram os principais eixos de transporte ferroviário e rodoviário na direção de São Paulo, Belo Horizonte e interior do Estado, elementos que não foram previstos na lógica dos deslocamentos intra-urbanos e nem com uma visão de conjunto das necessidades da cidade, mas sim com a lógica das ligações de caráter nacional. Ver Ilustração 8 - Cidade do Rio de Janeiro - Principais Eixos Rodoviários e Ferroviários - 1960-1970. 


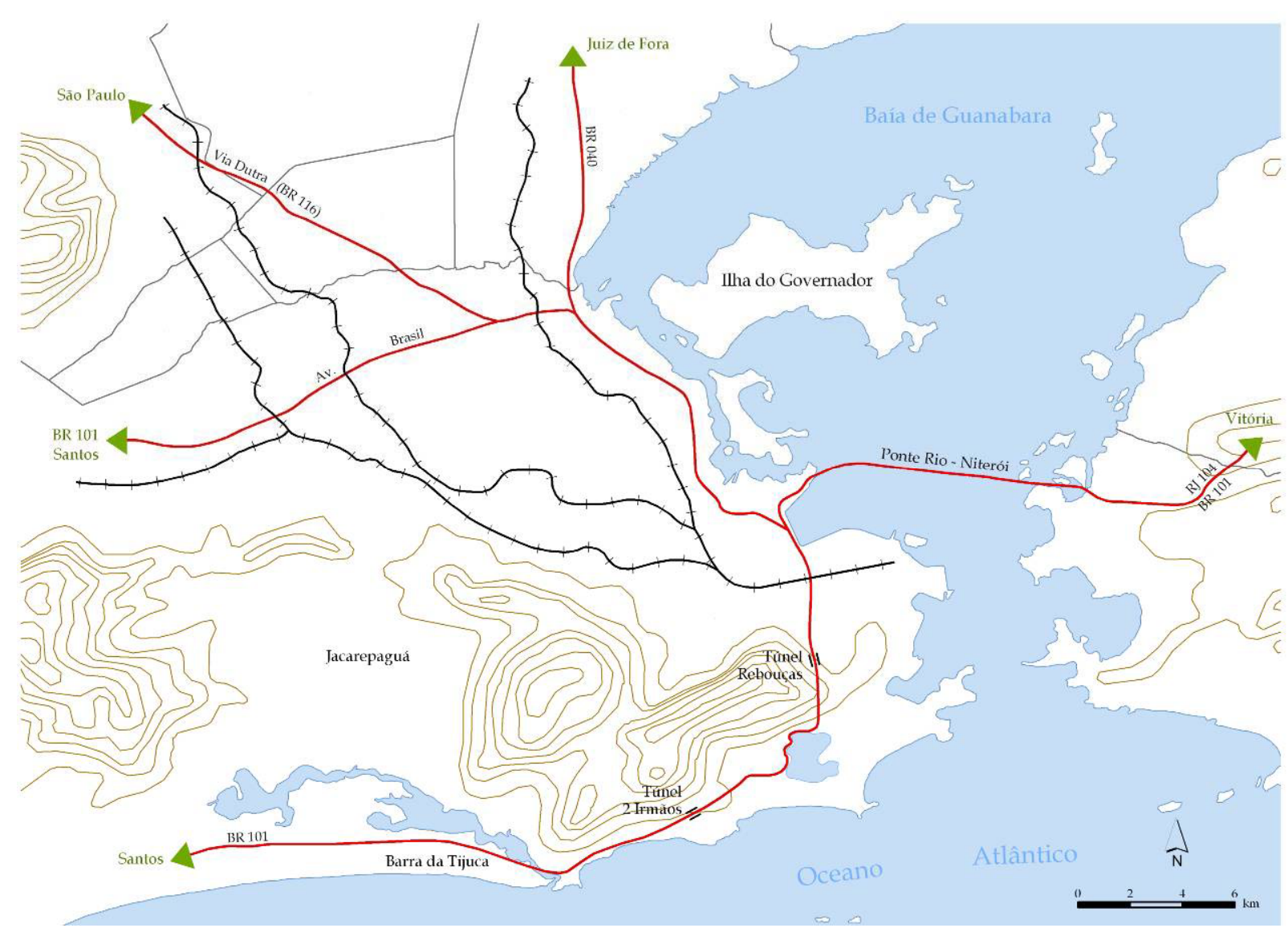

Ilustração 8 - Cidade do Rio de Janeiro - Principais Eixos Rodoviários e Ferroviários 1960-1970

A cidade se desenvolvia apertada entre montanhas, em corredores ao longo das praias e ocupando os vales. As distâncias eram grandes e praticamente não existiam ligações diretas entre as zonas Norte e Sul e as praias, acessíveis unicamente através do contorno dos morros seja pelo Centro ou a Oeste, por Jacarepaguá. Na década de 1960, mais uma obra de grande envergadura, o Túnel Rebouças veio ligar esses dois tentáculos da mancha urbana, na administração do Governador Carlos Lacerda. Destaca-se nesse mesmo governo a execução do projeto urbanístico e arquitetônico de Affonso Eduardo Reidy e paisagístico de Burle Marx para o Aterro do Flamengo, cujas obras de aterramento foram executadas na década de 1950, constituindo um quarto ciclo de grandes obras urbanas. Paralelamente, foi elaborado em 1965 o Plano Doxiadis, Plano de Desenvolvimento com enfoque global dos problemas da cidade e 
que propunha uma organização territorial na forma de comunidades urbanas hierarquizadas ancoradas numa malha viária projetada que se estendia por todo o território municipal.

Grandes obras de perfuração de túneis continuaram na década de 1970, através dos grandes investimentos feitos na ligação do Leblon com a Barra da Tijuca, pelo Túnel Dois Irmãos. Esta área, distante do Centro cerca de $30 \mathrm{~km}$ ao longo da orla, experimentou acelerado desenvolvimento urbano aberto às classes de renda mais altas. Simultaneamente, na porção oeste da cidade, a ocupação da Baixada de Jacarepaguá começava a despontar com taxas significativas de crescimento, chegando a atingir 56,3\% de crescimento demográfico no período 1970-1980.

A Ponte Rio-Niterói, com pouco mais de 13 km de extensão, cruzou a Baía de Guanabara, facilitando o fluxo para Niterói e para Leste na direção das praias fluminenses e para Norte, na direção do fundo da Baía e dos principais eixos rodoviários. Em 1978 entrou em funcionamento o primeiro trecho do sistema de metrô, completando um quinto e último ciclo de grandes obras iniciado com a fusão dos dois estados, 10 anos depois da aprovação do seu Estudo de Viabilidade e da criação da Companhia do Metrô-RJ.

Os vetores de urbanização da Região Metropolitana do Rio de Janeiro, estreitamente ligados à oferta de transportes na década de 1980 podem ser observados através da Ilustração 9 Cidade do Rio de Janeiro - Vetores de Crescimento no final do século XX, conforme abaixo:

1. Ao longo da Estrada de Ferro Central do Brasil e Rodovia Presidente Dutra, na direção de São João do Miriti, Nilópolis e Nova Iguaçu;

2. Ao longo da Estrada de Ferro Leopoldina, BR-040 e BR-116, na direção de Duque de Caxias e Magé; 
3. Ao longo do ramal de Santa Cruz da Estrada de Ferro Central do Brasil e Av. Brasil, na direção de Bangu e Campo Grande;

4. Através da área suburbana do Rio de Janeiro, em direção à Baixada de Jacarepaguá;

5. Ao longo da BR-101, auto-estrada Lagoa-Barra, na faixa litorânea do Município;

6. Ao longo da BR-101, através da Ponte Rio-Niterói, na direção de São Gonçalo, Itaboraí;

7. Através da Ponte Rio-Niterói, em direção aos lagos Fluminenses, na dependência da construção da Via Litorânea.

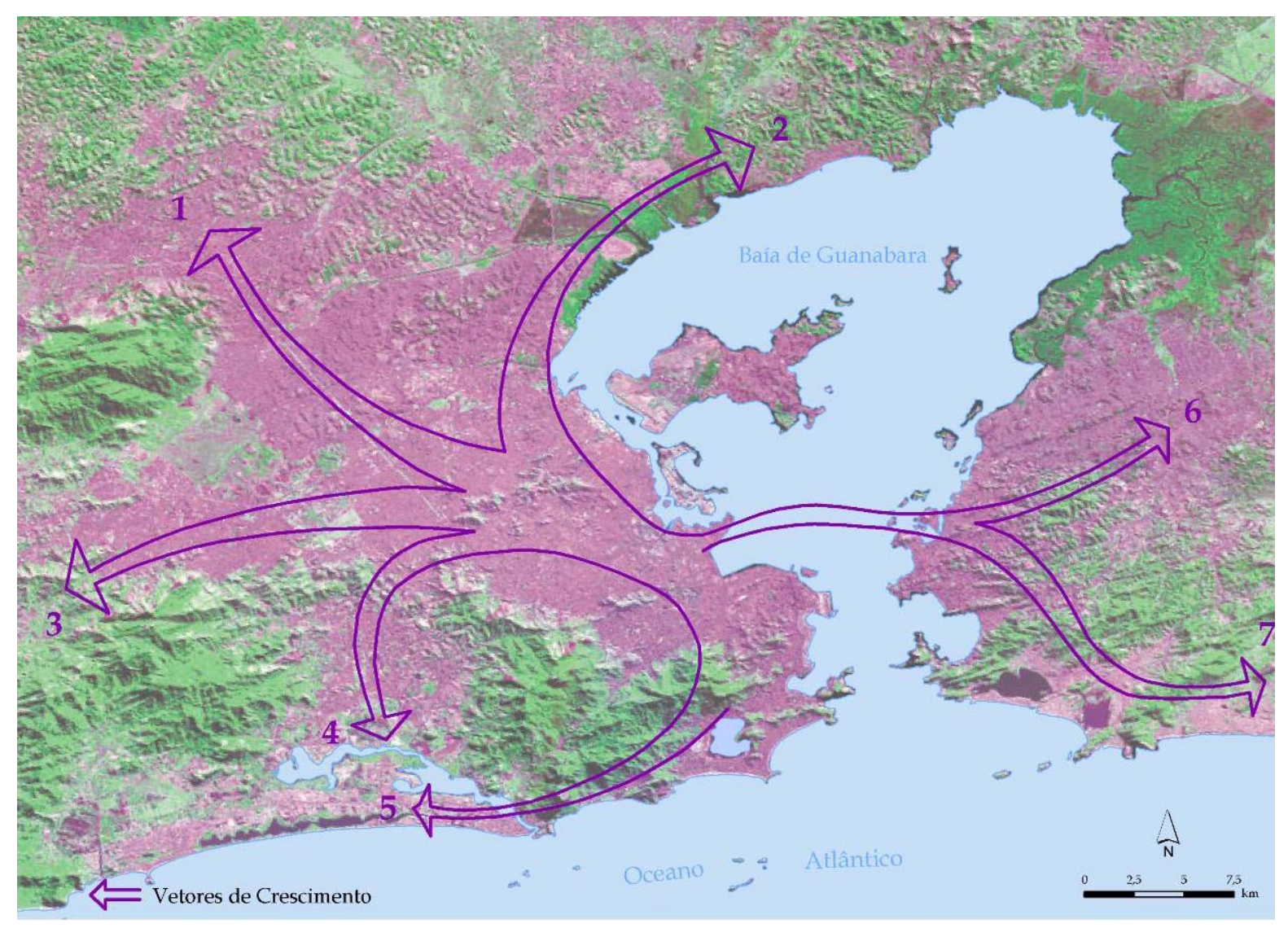

Ilustração 9 - Cidade do Rio de Janeiro - Vetores de Crescimento no final do século XX

Contrariando a história das grandes obras urbanísticas da cidade do Rio de Janeiro, poucas foram as realizações de grande porte nas duas últimas décadas do século XX e início deste. Destacam-se recentemente como intervenções na organização territorial municipal: a Linha 
Vermelha e a Linha Amarela. Ambas previstas na malha viária estudada nos anos 1960 com o objetivo de melhorar as condições de ligação e circulação entre a Zona Sul e as áreas mais interiorizadas. A primeira, fazendo a ligação dos bairros nobres da Zona Sul, dando continuidade ao complexo viário a partir do Túnel Rebouças até o Aeroporto Internacional na Ilha do Governador e às saídas rodoviárias da cidade. Já a Linha Amarela faz a ligação direta entre a Barra da Tijuca, atual localização consolidada das classes emergentes mais favorecidas - atraídas pelos serviços altamente diversificados e especializados que o bairro oferece - também com o aeroporto internacional e as saídas da cidade.

A redução do ritmo de crescimento do país com reflexos na significativa redução de investimentos nos territórios municipais, na diminuição da capacidade de endividamento municipal e com a mudança das práticas de gestão pública com a Lei de Responsabilidade Fiscal, fizeram com que as grandes obras públicas praticamente desaparecessem das agendas municipais. No entanto, os problemas continuaram a crescer, especialmente nas grandes metrópoles, de modo que hoje na cidade do Rio de Janeiro podem ser observadas situações de grandes desequilíbrios.

O crescimento das ocupações clandestinas, em especial nas áreas menos adequadas aos assentamentos, nas áreas de preservação ambiental dos morros da Zona Sul e Oeste, nas áreas sujeitas a inundações ao longo da orla da Baia da Guanabara, bem como o crescimento dos loteamentos irregulares em áreas até adequadas à ocupação, mas sem dotação de infraestrutura básica, e ainda com o crescimento da insegurança da vida urbana, faz com que os problemas urbanos fiquem cada vez mais visíveis e a pouca capacidade de investimento municipal tenha que ser utilizada de forma mais eqüitativa. As três últimas administrações municipais, de 1997 a 2008, têm investido nos programas de urbanização de favelas e de 
regularização fundiária - Programas Favela-Bairro -, embora tenham implantado planos de melhoria e embelezamento em vários bairros da cidade - Programa Bairro-Cidade. Intervenções com obras de grande porte, como foi a prática durante mais de um século, não foram propostas nem executadas e é com muita dificuldade e lentidão que as duas únicas linhas de Metrô vêm sendo ampliadas, mesmo com a privatização do sistema. A implantação recente das duas vias expressas - Linha Vermelha e Linha Amarela - nem de perto podem ser comparadas aos esforços que foram feitos na abertura de túneis, no desmonte de morros e nos aterros da orla litorânea e da Baía da Guanabara, quando se avalia recursos e oportunidades tecnológicas nos dois momentos de realização.

Embora a cidade tenha sido objeto de planos urbanísticos com uma visão de conjunto que incluíam propostas para o sistema de transportes urbanos, abordando a estreita relação entre eixos de transporte e desenvolvimento urbano, o histórico da realização de empreendimentos/obras estruturais na cidade se mostra desconectado desses planos. Foram realizadas a partir de uma lógica pontual de implantação de melhorias de embelezamento e expansão do sistema viário, enquanto iniciativas do poder público. Já o setor privado soube se aproveitar dessa estreita relação à época da implantação do sistema de bondes e da criação de novos bairros sem, no entanto, obedecer a qualquer direcionamento do desenvolvimento geralmente advinda da administração pública, que poderia trazer à cidade uma ocupação mais equilibrada, numa visão mais abrangente.

Mesmo dispondo de um volume de recursos significativo ao longo de todo o período enquanto Distrito Federal e enquanto estado da Guanabara e de condições institucionais que propiciavam grandes realizações, nada se fez no sentido de dotar a região de um sistema de transporte de massa condizente com seu tamanho e importância nacional. E como veremos em 
seguida, ao contrário, os governantes perderam grandes oportunidades de estruturação da ocupação urbana, em especial, por nunca terem considerado a implantação de um sistema metroviário como um caminho para essa orientação do desenvolvimento urbano, como tantas cidades no mundo lograram fazer.

As decisões tomadas pelo poder público ao longo da história urbanística da cidade do Rio de Janeiro foram orientadas no sentido da oferta de obras com forte apelo simbólico enquanto que a iniciativa privada, agindo como promotora do desenvolvimento urbano, soube responder às demandas existentes e até mesmo criá-las em momentos específicos. 
CAPÍTULO 04 


\section{COMO SE DESLOCA A POPULAÇÃO METROPOLITANA}

Este capítulo ${ }^{1}$ apresenta a situação da oferta dos transportes coletivos na cidade do Rio de Janeiro nos últimos cem anos, detalhando os períodos mais críticos de operação dos sistemas implantados de forma a se construir um quadro de problemas e soluções viabilizadas nesses momentos. Tem por objetivo situar as principais idéias e iniciativas de se implantar o sistema metroviário dentro desse quadro, ressaltando-se as decisões tomadas pelo poder público e em especial, as decisões não tomadas e que contribuíram para as condições precárias de deslocamento que permanecem na região.

Os serviços de transporte coletivo na cidade do Rio de Janeiro se iniciaram em meados do século XIX, com a implantação das primeiras companhias de carris urbanos - bondes ${ }^{2}$ - e as primeiras linhas de trens de passageiros ${ }^{3}$. A rede de bondes funcionou até 1964 e chegou a uma

\footnotetext{
${ }^{1}$ Este capítulo se apoia substancialmente nas seguintes publicações:

BARAT, J. Estrutura Metropolitana e Sistema de Transportes: Estudo de Caso do Rio de Janeiro. IPEA Série Monográfica, no. 20, Rio de Janeiro, 1975. 292 p.

CONSÓRCIO LOGIT - OFICINA - JGP. Plano Diretor de Transporte Urbano da Região Metropolitana do

Rio de Janeiro - PDTU. Capítulo 2 - Estrutura do Serviço Atual de Transportes. [S.l.: s.n.], 2004, 51 p. e Capítulo 3 - Prognóstico. [S.l.: s.n.], 2005, 33 p.

IPEA/IPLAN. Região Metropolitana do Grande Rio: Serviços de Interesse Comum. Brasília: IPEA, 1976, 247 p. PREFEITURA DA CIDADE DO RIO DE JANEIRO, Secretaria Municipal de Planejamento e Coordenação Geral. PUB Rio, Plano Urbanístico Básico da Cidade do Rio de Janeiro. Rio de Janeiro, jun. 1977. 280 p. SAPSA, Governo do Estado do Rio de Janeiro, FUNDREN. Plano Diretor de Transportes da Região Metropolitana do Rio de Janeiro - Diagnóstico. Documento de Trabalho, [1980].

SCHNOOR, J. A Harmonia do Desenvolvimento Urbano em Função da Rede de Transporte Coletivo de Massa. Rio de Janeiro: BNH, 1975. 127 p.

SILVA, M. L. P. Os Transportes Coletivos na Cidade do Rio de Janeiro: Tensões e Conflitos. Prefeitura da Cidade do Rio de Janeiro, Secretaria Municipal de Cultura, Turismo e Esportes, coleção Biblioteca Carioca, v 20, 1992. 177 p.
}

${ }^{2}$ A primeira concessão de linha de bonde, aqui entendido como veículo de transporte urbano sobre trilhos, foi feita em 1856, sendo que os serviços começaram em 1859, ligando a atual Praça Tiradentes ao Alto da Tijuca e prosseguiram até 1866. Inicialmente por tração animal, essa linha recebeu locomotivas a vapor que funcionaram de 1862 a 1866. Em seguida, a partir de 1868, novas concessões foram outorgadas, totalizando cerca de 40 autorizações até 1905 .

\footnotetext{
${ }^{3}$ De acordo com Maria Lais Pereira da Silva, acima citada, o Rio de Janeiro experimentou, a partir de 1870, a “revolução dos transportes”: implantação de estradas de ferro - especificamente, o sistema voltado para os subúrbios -, das linhas de bonde da Zona Norte e Zona Sul e do tráfego regular das barcas para Niterói. Este conceito reforça a idéia de passagem da cidade colonial - onde os deslocamentos eram feitos a pé ou a tração animal - para uma situação que exige uma maior complexidade de serviços urbanos, em função do crescimento
} 
extensão de cerca de 500 km de linhas que responderam, no auge de sua utilização em 1944, por uma mobilização de aproximadamente 709 milhões de passageiros/ano. Os trens de subúrbio, por sua vez, continuaram a transportar um contingente considerável de passageiros tendo passado por um período de estagnação e deterioração e atualmente experimenta uma fase de lenta recuperação. Atualmente, no entanto, são os ônibus os principais responsáveis pela movimentação de passageiros na Região Metropolitana do Rio de Janeiro, desempenhando uma função estrutural ao substituir os bondes e grande parte da movimentação antes feita pelos trens de subúrbio. Competem com os ônibus, os serviços de microônibus (vans, kombis e outros) que apresentam um grande índice de irregularidade e clandestinidade. O Metrô, que pouco expandiu os limites das duas linhas existentes desde sua implantação inicial, no final dos anos 1970 e início dos anos 1980, oferece hoje um volume de viagens superior aos trens de subúrbio. O serviço de transporte coletivo através de barcas, catamarãs e aerobarcos, cumpre um importante papel de ligações internas à Baia da Guanabara embora, em valores absolutos de número de viagens, sua presença seja inexpressiva.

O transporte público na Região Metropolitana atinge praticamente toda a área urbanizada, mas os níveis de regularidade, conforto e tempo de percurso ficam a desejar. Adicionalmente, os modos não apresentam complementaridade, podendo-se observar superposição de percursos num desperdício de recursos evidente. São poucos os canais de circulação segregados para os modos rodoviários e os mesmos não apresentam desempenho adequado, contribuindo para os níveis de congestionamento. A organização geral do sistema de transportes é precária, cada modo responde a sua lógica particular, a despeito de que um grande número de planos de transporte tenham sido realizado, sendo porém o atendimento aos mesmos muito restrito.

populacional e conseqüente expansão da área urbana. Observa-se um ganho expressivo de acessibilidade das áreas periféricas com relação ao centro e a possibilidade de ligações internas ao centro da cidade. 


\subsection{Bondes}

Os bondes ${ }^{4}$ foram os responsáveis pela estruturação das áreas centrais e pelo desenvolvimento urbano nas direções da Zona Norte e da Zona Sul. Os serviços foram inicialmente concedidos a indivíduos e pequenas empresas locais, sendo que os termos das concessões estabeleciam as respectivas áreas territoriais e prerrogativas na prestação dos serviços.

Na direção da Zona Norte, os bondes possibilitaram a ligação dos bairros nobres do império freguesias de São Cristóvão e Engenho Velho - com as áreas centrais da cidade, passando por regiões densamente ocupadas por população de baixo poder aquisitivo, como Saúde e Gamboa, em boa parte ocupadas por cortiços. Também na Zona Norte, surgiram novos bairros: Rio Comprido, Catumbi e Vila Isabel. Os bairros da Zona Sul - Glória, Copacabana, Jardim Botânico e região da Lagoa Rodrigo de Freitas - se desenvolveram com a implantação das linhas de bondes, constituindo extensas áreas urbanizadas, as novas localizações das elites republicanas. As oportunidades residenciais junto à praia de Copacabana foram viabilizadas com a inauguração do túnel de acesso a partir do Botafogo em 1892. De maneira geral, os investimentos imobiliários estiveram diretamente ligados aos investimentos nas linhas de bonde, tanto na Zona Norte quanto na Zona Sul, num processo de auto-alimentação. O espaço urbano era desenhado e efetivamente construído segundo os interesses dos principais grupos: o poder público, as concessionárias dos serviços e o capital imobiliário, definindo claramente os novos centros e as novas periferias urbanas. Cabe lembrar que em 1890, a cidade do Rio de Janeiro contava com cerca de 500.000 habitantes e que o período anterior, de

\footnotetext{
${ }^{4}$ Anteriormente ao sistema de bondes, de acordo com a SECTRAN - Secretaria de Estado de Transportes do Governo do Estado do Rio de Janeiro, Evolução dos Transportes de Passageiros no Rio de Janeiro, disponível em: <http://www.sectran.rj.gov.br>, acesso em: 25 jan. 2007, gôndolas e diligências à tração animal foram introduzidas no interior das áreas urbanas, como transporte coletivo, em meados da segunda década do século XIX. Os primeiros ônibus, também à tração animal, começaram a trafegar no final dos anos 1830, transportando cerca de 20 passageiros em cada unidade.
} 
aproximadamente 40 anos, foi de intenso crescimento demográfico, quando a cidade passou de 100.000 para 500.000 habitantes.

Linhas de grande extensão foram sendo implantadas, respondendo às necessidades da população e da expansão urbana. Linhas periféricas e associadas ao trem de subúrbio também merecem destaque, como aquela concedida à Companhia de Jacarepaguá, ligando a estação ferroviária de Cascadura à freguesia de Nossa Senhora do Loreto de Jacarepaguá, indo até o largo do Tanque, numa extensão aproximada de $6 \mathrm{~km}$, com o objetivo inicial de transportar produtos agrícolas da região.

Numa disputa por espaços privilegiados de atuação, as inúmeras companhias de carris urbanos foram aos poucos se fundindo em empresas maiores, cujo capital passou a ser predominantemente estrangeiro. No final do século XIX, as principais empresas eram as seguintes, operando linhas a partir do Centro:

- Companhia do Jardim Botânico (The Botannical Garden Railroad Company, posteriormente Cia. de Ferro Carril do Jardim Botânico) - linhas para a Zona Sul da cidade;

- Companhia de São Cristóvão (The Rio de Janeiro Street Railway Limited) - linhas para a Zona Norte;

- Companhia de Vila Isabel - linhas da Zona Norte da cidade;

- Companhia de Carris Urbanos - linhas do Centro e Porto.

Já no século XX, iniciou-se um período de grandes alterações tecnológicas e urbanísticas, com a eletrificação do sistema e com alterações significativas no tecido urbano, como já vimos, propiciadas pelas reformas do Prefeito Pereira Passos. Entrou em operação na cidade, na área de transportes, a empresa The Light and Power Company, que já detinha o monopólio 
da energia elétrica no Rio de Janeiro e em outras áreas do país e que constituiu a The Rio de Janeiro Tramway Light and Power Company. Esta, alicerçada na modernização do sistema através da eletrificação, iniciou um processo de unificação das empresas de carris urbanos através de compras e acordos, chegando a estabelecer um monopólio também nesse setor ${ }^{5}$.

Os bondes elétricos alteraram significativamente os costumes da cidade com o aumento expressivo de viagens, número de linhas e dimensão de veículos, e, de certa forma, conseguiram aliviar a pressão da demanda por transporte, ao mesmo tempo em que criaram uma demanda adicional, resultado dos novos padrões de urbanização da cidade. Ver Ilustração 10 - Mapa do Sistema de Bondes 1907 e 1946.

Houve uma tentativa de concorrência com o sistema de bondes através do projeto de implantação de trens elevados ${ }^{6}$ - a Metropolitana -, concessão outorgada em 1891 para o Banco dos Estados Unidos do Brasil e para o engenheiro Pedro Caminada. Este projeto foi severamente criticado pelas companhias de bondes e não obteve sucesso; ao ligar o Largo da Carioca aos subúrbios e à Ilha do Governador como se pretendia, este sistema embrionário de Metrô concorreria diretamente com a Companhia São Cristóvão.

\footnotetext{
${ }^{5} \mathrm{O}$ estabelecimento de monopólios encontra oposição em vários setores da sociedade, existindo mesmo o Decreto Legislativo no. 1.001, datado de 21/10/1904 que proibia a concessão de privilégio exclusivo para qualquer aplicação de energia elétrica no Distrito Federal. No entanto, a Light conseguiu o monopólio da energia elétrica e uma presença maciça no ramo altamente lucrativo dos transportes urbanos por carris. Também conseguiu opções de compra, totais e parciais, de empresas de gás, telefonia e viação, operando na forma de uma empresa/grupo “multiutilities”. Ver detalhes em SILVA, M. L. P. Os Transportes Coletivos na Cidade do Rio de Janeiro: Tensões e Conflitos. Prefeitura da Cidade do Rio de Janeiro, Secretaria Municipal de Cultura, Turismo e Esportes, coleção Biblioteca Carioca, v 20, 1992. 177 p., acima citado.

${ }^{6}$ Cerca de 20 projetos de trens elevados foram apresentados num período de dois anos - 1890 e 1891 -, mas somente o da Metropolitana obteve concessão pública.
} 


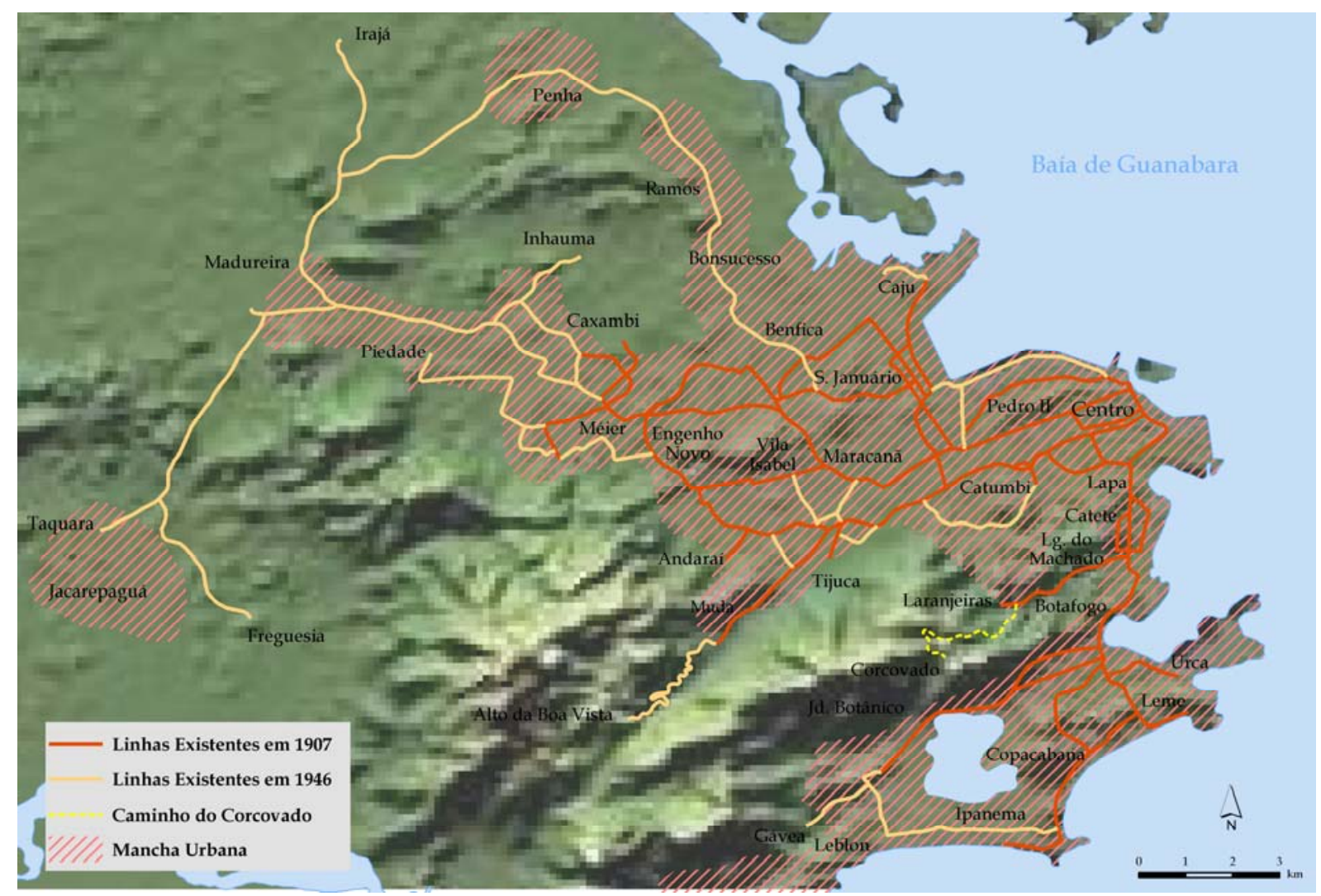

Referência: SCHNOOR, J. A Harmonia do Desenvolvimento Urbano em Função da Rede de Transporte Coletivo de Massa. Rio de Janeiro: BNH, 1975. 127 p.

\section{Ilustração 10 - Mapa do Sistema de Bondes 1907 e 1946}

Os serviços de transporte coletivo através dos bondes, observados pelo volume de passageiros transportados, foram crescentes até $1944^{7}$, quando a competição exercida pelos ônibus alterou o quadro. O número de passageiros transportados/ano passou a decrescer até o ano de $1964^{8}$, data da extinção dos serviços, embora nesse ano os bondes ainda tenham transportado um número significativo de pessoas, cerca de 225 milhões, o que corresponde a aproximadamente 18\% do volume total transportado no ano na cidade do Rio de Janeiro. Cabe ressaltar que foi só no ano de 1968 que o número de passageiros transportados pelos ônibus na cidade do Rio de Janeiro ultrapassou o número de passageiros transportados pelos bondes, no auge dos

\footnotetext{
${ }^{7}$ Inicialmente os bondes eram um transporte de elite, mas que passou a ser usado por grande parte da população. ${ }^{8}$ A concessão relativa à Companhia do Jardim Botânico expirou no final do ano de 1960. Em 1961, a operação dos serviços passou a ser feita pela Junta de Administração Provisória dos Serviços de Bonde da Zona Sul. Nessa época, iniciou-se a implantação dos serviços de trólebus na zona Sul e, em 1964, a Junta de Administração Provisória desativou as linhas de bonde. Na Zona Norte, os trólebus passaram a substituir os bondes, mas não se mostraram tecnicamente adequados. Em 1969, os bondes circulavam apenas no bairro de Santa Teresa.
} 
serviços em 1944. Josef Barat ressalta que no início do século XIX eram poucas as cidades no mundo, com dimensões populacionais e territoriais semelhantes ao Rio de Janeiro, que possuíam um sistema de transporte coletivo tão eficiente.

Josef Barat e Maria Lais Pereira da Silva, simultaneamente e em obras separadas, indicam como as principais razões para a desativação do sistema de bondes, o aumento da competição com os serviços de ônibus ${ }^{9}$, o serviço deficitário e ineficiente decorrente da obsolescência do material rodante, as crises de energia elétrica ocorridas nos anos 1950, a expansão do uso do automóvel, a visão de que os bondes eram os responsáveis pelo crescimento dos congestionamentos e pelos serviços inadequados e ainda, os planos setoriais que preconizavam soluções “mais modernas” para os problemas dos transportes urbanos em geral $^{10}$. Cabe observar que a Companhia Light tentou “modernizar" a rede de bondes ao propor, em dois momentos, a implantação de um sistema metroviário, na realidade bondes subterrâneos, em trechos curtos na área central mais congestionada.

Resta hoje em operação no município do Rio de Janeiro apenas o Sistema de Bondes de Santa Teresa, com uma frota operacional de 10 veículos, percorrendo uma extensão de 8 km, e que transportou no ano de 2005 cerca de 640 mil passageiros ${ }^{11}$, sob a responsabilidade da estatal CENTRAL - Companhia Estadual de Engenharia de Transportes e Logística.

\footnotetext{
${ }^{9}$ Com a política de liberalização das importações foi possível a entrada em circulação dos ônibus americanos, de alta capacidade.

${ }^{10}$ Cabe lembrar que a concessão para o serviço de bondes expirou em 1960 e não houve interesse por parte do setor público em sua renovação, e nem mesmo por parte da empresa nas condições ofertadas, conforme apontado por DUARTE, R. G. Centralidade, acessibilidade e o processo de reconfiguração do sistema de transporte na metrópole carioca dos anos de 1960. In: Revista Território. Rio de Janeiro, ano VII, no. 11, 12 e 13, . p. 91-106, set./out. 2003.

${ }^{11}$ Segundo dados obtidos através da Tabela 440 - Movimento de passageiros segundo os transportes rodoviário, ferroviário, hidroviário e aeroviário 1995-2005 disponível na página de dados estatísticos da PMRJ $<$ http://www.armazemdedados.rio.rj.gov.br>, acesso em 11 fev. 2007, cujas fontes são: Superintendência de Transportes Urbanos - SMTU; RIOÔNIBUS; Companhia do Metropolitano do Rio de Janeiro - METRÔ-RJ; Opportrans Concessão Metroviária S.A. - METRÔ-RIO; Companhia Fluminense de Trens Urbanos -
} 


\subsection{Trens}

A implantação do sistema de trens suburbanos foi contemporânea à do sistema de bondes ${ }^{12}$ e foi a principal responsável pela consolidação da ocupação das áreas periféricas da cidade e de núcleos isolados na Baixada Fluminense. Com a crescente urbanização das áreas ao redor das estações dos subúrbios, ao longo das quatro linhas de trem - Estrada de Ferro Central do Brasil, Linha Auxiliar da Empresa Melhoramentos, Estrada de Ferro Rio do Ouro e a Estrada de Ferro Leopoldina -, a movimentação de passageiros cresceu ininterruptamente durante a primeira metade do século XX até um ápice no início dos anos 1960. Ver Ilustração 11 Linhas de trem no início do Século XX.

Da mesma forma que nos serviços de bondes, inicialmente, o setor ferroviário foi dominado pelo capital estrangeiro, que detinha a maior parte das concessões, e também apresentou a mesma dinâmica de fusão de empresas e monopolização dos serviços. Porém, diferentemente do serviço de bondes, o setor dispunha de um mecanismo de garantia de lucros sobre o investimento; o Estado, através de determinação legal ${ }^{13}$, Decreto no. 641 de 1852, garantia um percentual de $5 \%$ de rendimentos sobre o capital investido, de forma que a ferrovia passou a ser um bom negócio no Brasil. Foram implantadas nessa época: Companhia de Navegação a

FLUMITRENS; SUPERVIA S.A.; Transporte Marítimo e Turismo S.A. - TRANSTUR; Barcas S. A.; Companhia de Navegação do Estado do Rio de Janeiro - CONERJ; Empresa Brasileira de Infra-estrutura Aeroportuária - INFRAERO.

${ }^{12}$ A primeira concessão para o serviço de trens se deu no período da regência de Diogo Feijó, em 1835, para a ligação da Capital do Império às províncias de Minas Gerais, Rio Grande do Sul e Bahia. Em 1840, foi feita uma concessão para a ligação do Rio de Janeiro com a província de São Paulo. Eram ligações de longa distância que partiam da cidade.

${ }^{13}$ As determinações legais que respaldavam os investimentos incluíam além dos juros garantidos, o direito de desapropriação de terras nos locais de interesse para o traçado, a cessão de terras devolutas, bem como privilégios na zona de $30 \mathrm{~km}$ nas duas margens da linha. Incluía também isenção de impostos de importação sobre materiais específicos como trilhos, máquinas etc. 
Vapor e Estrada de Ferro Petrópolis, posteriormente Estrada de Ferro Mauá (1854) ${ }^{14}$; Estrada de Ferro D. Pedro II (1855) (1 $1^{\text {o. }}$ trecho, 48 km entre a Estação da Corte - atual D. Pedro II - e Queimados, posteriormente Estrada de Ferro Central do Brasil); Leopoldina Railway (1871) e Estrada de Ferro Rio do Ouro (1875), constituindo a rede suburbana.

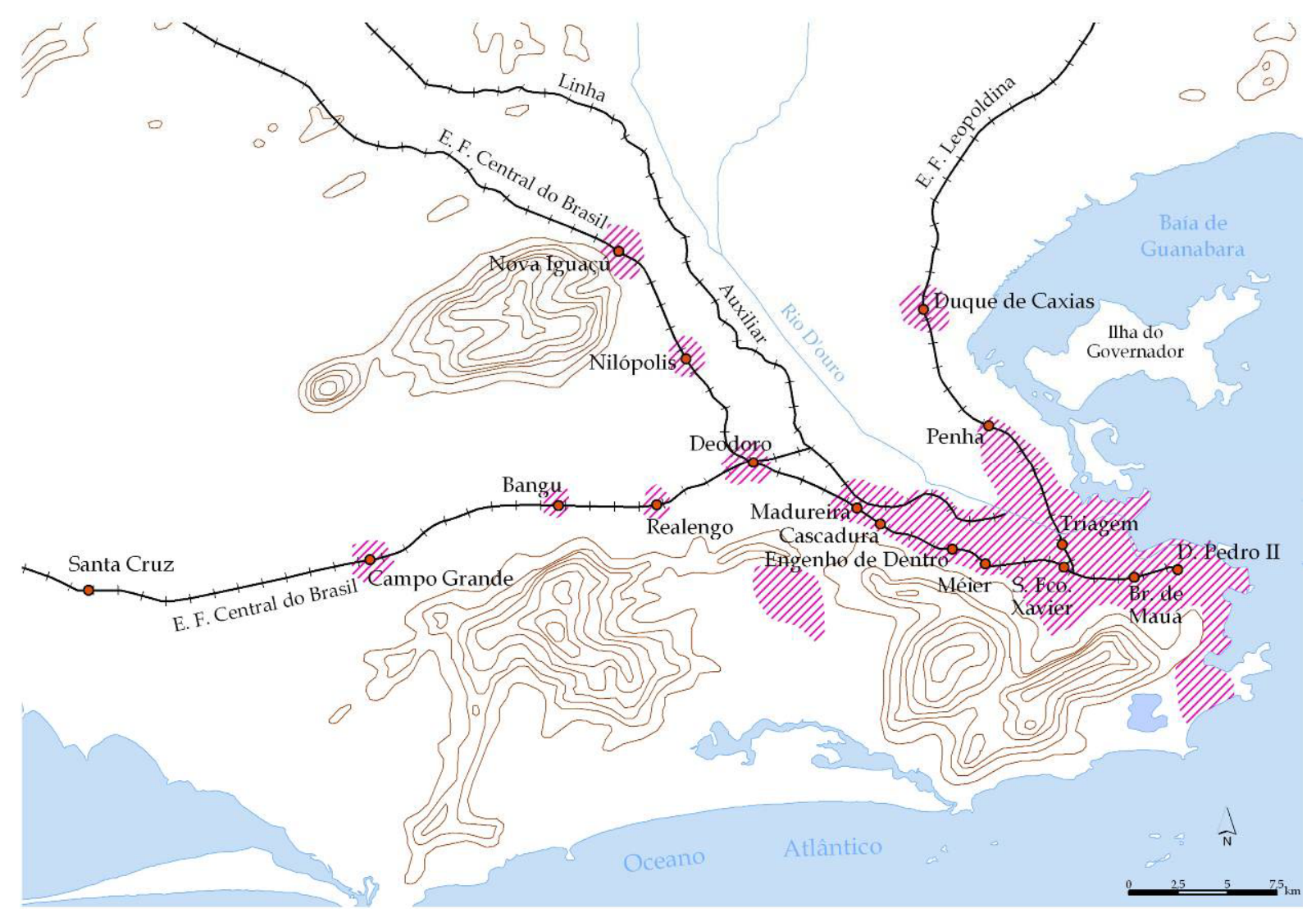

Referência: SCHNOOR, J. A Harmonia do Desenvolvimento Urbano em Função da Rede de Transporte Coletivo de Massa. Rio de Janeiro: BNH, 1975. 127 p.

\section{Ilustração 11 - Linhas de Trem no início do Século XX}

A Estrada de Ferro São Paulo-Rio de Janeiro foi criada pelo mesmo Decreto 641 e constituiuse uma empresa em 1855 para fazer a ligação entre o Rio de Janeiro e Minas Gerais e entre o

\footnotetext{
14 Trecho de 14,5 km entre as estações Guia de Pacobaíba e Fragoso, ligando o Porto de Mauá à raiz da serra de Petrópolis, integrado às barcas que ligavam a Estação Guia de Pacobaíba ao Cais Pharoux (Praça Mauá), segundo a Cronologia do Anuário ANTP dos Transportes Públicos em ANTP - Associação Nacional de Transportes Públicos. Anuário ANTP dos Transportes Públicos. São Paulo, 1996. 250 p.
} 
Rio e São Paulo. Em 1858, foi inaugurado o primeiro trecho e em 1864 a ferrovia já tinha subido a serra, em Barra do Piraí.

Diferentemente dos demais empreendimentos, a Estrada de Ferro D. Pedro II era de grande interesse do poder imperial, de forma que em 1865 o governo imperial encampou a companhia. Até o final do século XIX, várias outras estradas de ferro - a Rio do Ouro, a Cia. Melhoramentos do Brasil, trechos da Leopoldina e a Estrada de Ferro São Paulo-Rio de Janeiro - também foram encampadas sob o nome de Estrada de Ferro Central do Brasil ${ }^{15}$, já pelos governos republicanos.

A Estrada de Ferro Rio do Ouro surgiu da necessidade de se transportar material de construção para as redes de abastecimento de água da cidade - da Quinta do Caju às represas do Rio do Ouro. Autorizada em 1875, foi aberta provisoriamente para passageiros em 1883, trecho de $58 \mathrm{~km}$. O leito dessa ferrovia seria mais tarde transformado em avenida Automóvel Clube e receberia também o Pré-Metrô (Maria da Graça - Pavuna), atual Linha 2.

A Estrada de Ferro Cia. Melhoramentos do Brasil foi organizada pelo engenheiro Paulo de Frontin em 1890 e é a origem da Linha Auxiliar da Estrada de Ferro Central do Brasil, também encampada pelo governo e reconstruída em 1905.

A Leopoldina Railway Co. obteve concessão em 1872 para ligar Leopoldina, em Minas Gerais, a Porto Novo da Cunha, no rio Paraíba. Expandiu-se rapidamente mas, com a crise do café na sua região de atuação, redirecionou seus interesses para o Rio de Janeiro ao comprar várias pequenas empresas e concessões nas proximidades do município. Segundo Maria Lais

\footnotetext{
${ }^{15}$ Informações obtidas através da Cronologia do Anuário da ANTP dos Transportes Públicos, ANTP - Associação Nacional de Transportes Públicos. Anuário ANTP dos Transportes Públicos. São Paulo, 1996. 250 p.
} 
Pereira da Silva, o grupo da Leopoldina seguiu um caminho monopolista semelhante ao da Light and Power com relação aos bondes e passou a controlar também o tráfego das barcas para Niterói. Restaram no município, como empresas isoladas, a Estrada de Ferro de São Cristóvão ao Alto da Boa Vista e a Estrada de Ferro do Corcovado.

Cabe observar que quando as ferrovias se tornaram deficitárias, muitas delas também obsoletas, o governo encampou e socorreu o capital privado, mesmo às custas de significativos endividamentos junto a bancos estrangeiros.

Com a eletrificação dos trens suburbanos em meados da década de $1930^{16}$, novo ímpeto na ocupação suburbana pôde ser observado; o entorno das antigas estações se transformaram em bairros periféricos e se integraram definitivamente à dinâmica da cidade central, consolidando um extenso anel metropolitano. A demanda pelos serviços cresceu ininterruptamente até a II Guerra Mundial, apresentando um ápice em 1949, com 220 milhões de passageiros transportados. Teve alguns períodos de queda, mas voltou a crescer até 1962, quando começou a cair persistentemente.

Pode-se observar, portanto, que, a partir do início dos anos 1960, o transporte sobre trilhos entrou em declínio, tendo os bondes seu serviço bruscamente interrompido em 1964, quando ainda transportavam um número significativo de passageiros, como afirmado anteriormente. Os trens, que atingiram em 1962 uma movimentação de 296 milhões de passageiros/ano ${ }^{17}$,

\footnotetext{
${ }^{16}$ A viagem experimental do primeiro trem de subúrbio eletrificado foi em Janeiro de 1937, no trecho São Cristovão - Riachuelo da Estrada de Ferro Central do Brasil, segundo a Cronologia do Anuário da ANTP dos Transportes Públicos, ANTP - Associação Nacional de Transportes Públicos. Anuário ANTP dos Transportes Públicos. São Paulo, 1996. 250 p.

${ }^{17}$ Segundo BARAT, J. Estrutura Metropolitana e Sistema de Transportes: Estudo de Caso do Rio de Janeiro. IPEA - Série Monográfica, no. 20, Rio de Janeiro, 1975. 292 p., já citado, várias fontes de dados apresentam diferentes volumes de passageiros transportados/ano pelos serviços de trens suburbanos, sendo que o autor considera a mais confiável a contagem obtida diretamente nos arquivos da Estrada de Ferro Central do Brasil.
} 
mal conseguiram manter em 1970 a mesma movimentação de 1945, num período em que o intenso processo de metropolização do Rio de Janeiro adicionou um grande número de viagens à demanda por transporte nos eixos suburbanos, em direção ao centro da cidade. A decadência destes serviços, nesse intervalo de tempo, se deve, de uma parte, à estagnação de investimentos no setor ferroviário ${ }^{18}$ e, de outra, à rápida expansão do transporte rodoviário, através dos ônibus e automóveis.

A Estrada de Ferro Central do Brasil permaneceu sob domínio do Estado, na condição de uma autarquia e, em 1957 passou a se constituir numa empresa estatal, a RFFSA - Rede Ferroviária Federal S. A., juntamente com a Estrada de Ferro Leopoldina no Rio de Janeiro e outras 16 estradas de ferro em todo o Brasil. No início dos anos 1970 foram criadas divisões operacionais na RFFSA e o sistema de trens de subúrbio do Rio de Janeiro passou a integrar a 8 . Divisão de Subúrbios do Grande Rio. No final dos anos 1970 e início dos anos 1980 foram feitos investimentos na empresa com a compra de novos trens, cerca de 170 unidades $^{19}$.

Em 1984, o sistema de transportes urbanos por trens passou a ser gerido pela CBTU Companhia Brasileira de Trens Urbanos, companhia estatal criada na esfera federal com a missão de incorporar os principais sistemas de trens metropolitanos operados no Brasil. Nesse ano, os trens metropolitanos no Rio de Janeiro ultrapassaram a marca total de um milhão de passageiros transportados/dia no total, sendo 350 mil pagantes. Em seguida, o volume de

\footnotetext{
${ }^{18}$ Em 1936 foram comprados 78 trens unidades da série 100 fabricados na Inglaterra, compondo 60 TUEs (1 carro motor e 2 reboques); dez anos depois, em 1946, foram comprados mais 30 TUEs e entre 1950 e 1952 mais 6 TUEs. Em 1952 estavam em operação 91 TUEs. Em 1954 foram adquiridos 96 trens da série 200. Em 1964/1965 entram em operação 60 trens da série 400. Embora existissem aquisições de material rodante, são investimentos considerados pequenos para fazer face à demanda de uma população que cresceu muito, e principalmente, na direção dos trens de subúrbio. Informações obtidas na Cronologia do Anuário da ANTP dos Transportes Públicos, 1996.

${ }^{19}$ Em 1977 entraram em operação 30 trens da série 500 (Nipon Sharyo) e em 1980, 60 trens da série 800 (Santa Matilde) e 50 de fabricação Cobrasma. Em 1981, foram adquiridos 30 trens da série 700 de fabricação Mafersa. Informações obtidas na Cronologia do Anuário da ANTP dos Transportes Públicos, 1996.
} 
passageiros transportados pelo sistema de trens metropolitanos do Rio de Janeiro voltou a decrescer rapidamente. Em 1994, o sistema de transportes urbanos de passageiros do Rio de Janeiro foi incorporado à esfera estadual, cumprindo determinação constitucional, sendo criada a estatal FLUMITRENS - Companhia Fluminense de Trens Urbanos, diretamente ligada à SECTRAN - Secretaria de Estado de Transportes do Rio de Janeiro, que passou a se responsabilizar pelos serviços.

Em 1998, a operação do sistema de trens metropolitanos foi transferida para a iniciativa privada, através de concessão à empresa SUPERVIA, por um período de 25 anos renováveis por igual período. No entanto, a operação da malha ferroviária de passageiros do estado, acrescida do Sistema de Bondes de Santa Teresa, continuou na esfera pública estadual, com a sucessão da FLUMITRENS pela CENTRAL - Companhia Estadual de Engenharia de Transportes e Logística ${ }^{20}$.

A SUPERVIA opera hoje cinco corredores eletrificados - Deodoro, Santa Cruz, Japeri, Saracuruna e Belfort Roxo e o corredor Vila Inhomirim, em tração diesel. A extensão total da malha é de 220 km e 89 estações. A CENTRAL opera os corredores Guapimirim e Niterói Visconde de Itaboraí, num total de 75 km, 6 estações e 25 paradas, em tração diesel.

Durante todo esse período recente de alterações administrativas do sistema de trens de subúrbio, que passou da esfera federal, para a estadual sendo em seguida concedido para a iniciativa privada, o sistema recebeu investimentos do Governo Estadual, do Banco Mundial ${ }^{21}$

\footnotetext{
${ }^{20}$ Estado do Rio de Janeiro, Decretos $\mathbf{n}^{\mathbf{0}} \mathbf{2 7 . 8 9 8}$ de 9 mar. 2001, $\mathbf{n}^{\mathbf{0}} \mathbf{2 8 . 3 1 3}$ de 11 maio 2001 e $\mathbf{n}^{\mathbf{0}} \mathbf{2 1 . 8 4 6}$ de 18 jul 2001.

${ }^{21}$ Em 1992, foram compradas unidades da série 1000 (Mafersa e Cobrasma) com recursos do Governo Estadual. Em 1997, entraram em operação 10 TUEs reformadas com recursos do BIRD I. Informações obtidas na Cronologia do Anuário da ANTP dos Transportes Públicos, 1998.
} 
e da própria concessionária para sua recuperação.

O volume de passageiros transportados pelo sistema de trens na região metropolitana no ano 2000 chegou ao seu menor número nos últimos 50 anos, cerca de 80 milhões de passageiros, e a partir de então voltou a crescer lentamente, com o início da operação sob a responsabilidade da concessionária SUPERVIA e da CENTRAL, de forma que em 2005 o total de passageiros transportados já foi de 86 milhões, um valor que, entretanto, não chega a um terço daquele apresentado nos anos 1960, década de melhor desempenho do sistema. Observar a abrangência espacial do sistema através da Ilustração 12 - Mapa do sistema ferroviário em operação 2007 - SUPERVIA e CENTRAL, a seguir.

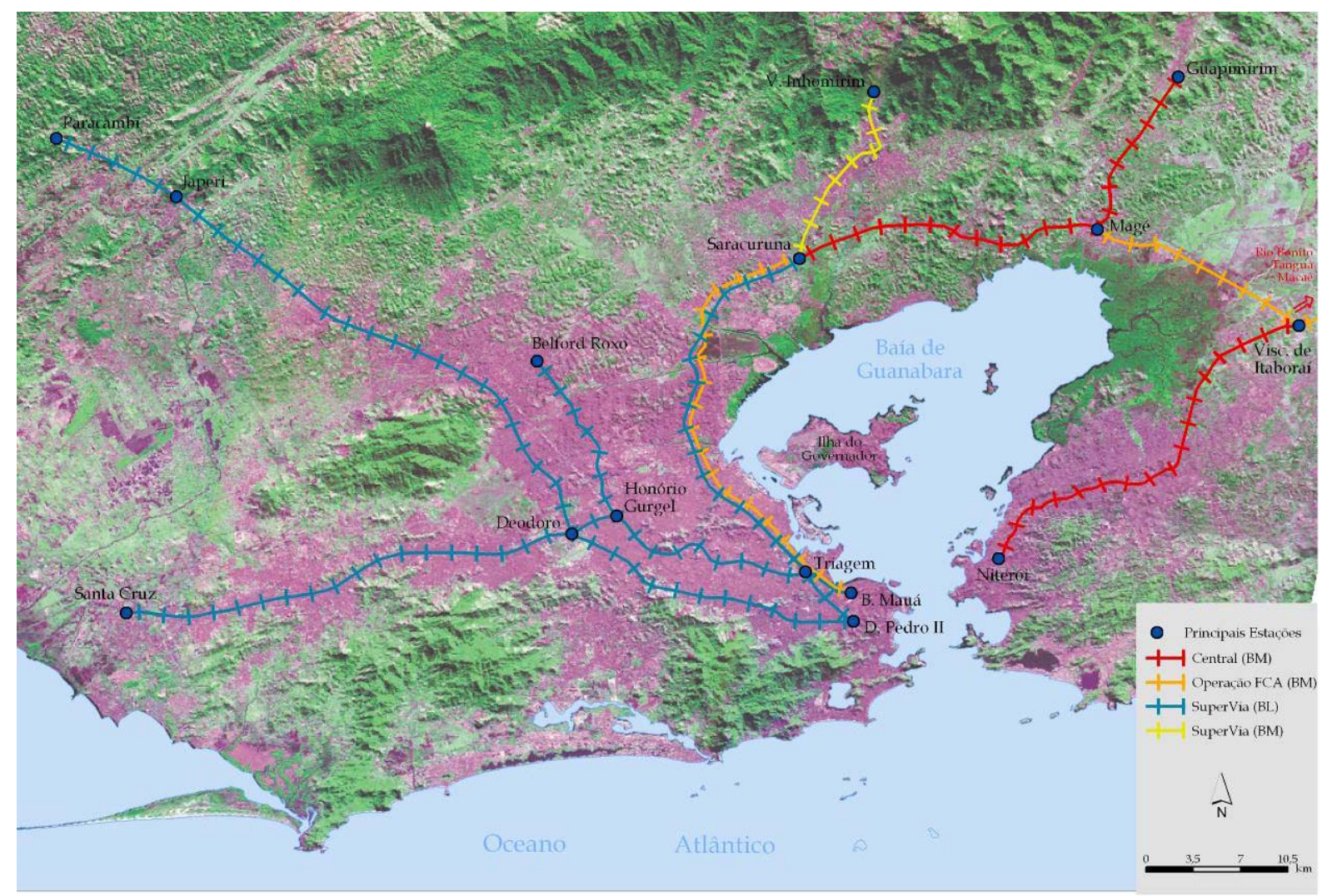

Referência: <http://www.supervia.com.br>, página oficial da Supervia S.A e <http://www.central.rj.gov.br>, página oficial da CENTRAL - Companhia Estadual de Engenharia de Transportes e Logística.

\section{Ilustração 12 - Mapa do Sistema Ferroviário em operação 2007 - SUPERVIA e CENTRAL}




\section{3 Ônibus e Microônibus (vans, kombis e outros)}

As atividades dos serviços de ônibus foram iniciadas no começo do século XX com características de complementaridade ao sistema de bondes, constituindo-se estes no real transporte de massas na primeira metade desse século. Serviam bairros novos e participavam do processo de adensamento populacional das áreas atendidas pelos bondes, ampliando assim, o alcance destes últimos. Com excepcional padrão de oferta, os ônibus eram, até os anos 1940, um transporte para um público sofisticado, enquanto os trens e os bondes eram responsáveis pela massa de passageiros transportados, 83,47\% do total nesse ano.

A década de 1940 foi um período de crescimento demográfico expressivo na periferia do Rio de Janeiro, que gerou um aumento significativo da demanda pelo transporte de trens, mas que não foi acompanhado pelos investimentos necessários. Ao final da década, o sistema ferroviário de subúrbio encontrava-se em precárias condições de tráfego, com trens superlotados e com circulação irregular. A insatisfação popular, expressa especialmente através dos quebra-quebras que ocorreram entre os anos de 1953 e $1959^{22}$, foi amplamente descrita por Maria Lais Pereira da Silva, já citada. Adicionalmente às condições físicas do sistema, existia uma visão depreciativa dos subúrbios enquanto local de residência da população pobre da cidade.

Duarte $^{23}$ afirma que o sistema de bondes passava por um período de crise, com a sua operadora, a Companhia Light, perdendo interesse pelo negócio, pois o governo passou a

\footnotetext{
${ }^{22}$ Depredações de trens (1953 e 1956), de bondes (1956 e 1957) e de barcas (1959) são descritas por Maria Lais Pereira da Silva; embora esse tipo de manifestação já ocorresse desde a década de 1920, acompanhada de greves dos trabalhadores do setor. As greves eram ainda anteriores e já ocorriam no final do século XIX e início do século XX.

${ }^{23}$ Ronaldo Goulart Duarte - já citado anteriormente.
} 
regular firmemente as tarifas a partir de meados da década de 1960, baixando a lucratividade da empresa. Além disso, as concessões estavam prestes a expirar ${ }^{24}$.

A partir do final da II Grande Guerra, o sistema de transporte por ônibus experimentou vigorosa expansão, iniciando-se então a substituição sistemática de bondes por ônibus, perdendo estes a sua função de complementaridade intermodal, para se transformarem em principal modalidade de transporte de massa, tanto urbano quanto suburbano. Esse período coincide com o surto rodoviário em grande parte do mundo e todas as principais áreas urbanas no Brasil acompanharam essa tendência. A legislação relativa às importações do governo Dutra facilitou a entrada de veículos automotores. Surgiu um número muito grande de novas empresas de ônibus e lotações, muitas firmas com um só veículo, o que dificultou a fiscalização por parte do poder público.

Duarte também afirma que houve uma clara política rodoviarista por parte do governo, em consonância com os novos paradigmas tecnológicos mundiais. Paralelamente, havia interesse em ver reduzida a influência da Companhia Light no setor de transportes, estimulando o aparecimento de novos interlocutores. Sem qualquer planejamento na urbanização dos subúrbios, os ônibus e lotações acompanharam o preenchimento dos vazios urbanos existentes entre as estações das estradas de ferro. Extremamente flexível, esse sistema conseguia dar conta dessa ocupação desordenada com um mínimo de investimento inicial ${ }^{25}$ e baixo custo de operação.

\footnotetext{
${ }^{24}$ A Companhia Light passou, no Rio de Janeiro, a concentrar e a limitar seus interesses no setor de distribuição de energia elétrica.

${ }^{25}$ Diferentemente dos sistemas sobre trilhos, veículos automotores podem iniciar sua operação em vias ainda precárias, sem pavimentação, e aos poucos melhorarem seus serviços com o investimento público gradativo nas vias de circulação.
} 
A movimentação por ônibus era crescente, numa tendência irreversível, com a ampliação da área urbanizada e com o aparecimento de novos sub-centros. A grande diversidade de tipos de viagens tornava o modal rodoviário o mais adequado a essa nova situação. Entraram em operação os ônibus de alta capacidade, em linhas diametrais de natureza estrutural, e o poder público investiu pesadamente em sistema viário, em obras destinadas à circulação de veículos automotores. Em 1956, o número de passageiros transportados/ano era de 230 milhões, chegando a 1.135 milhões em 1970. O ônibus na periferia passou a ser símbolo de modernidade, conforto e prestígio social, o oposto do que a população pensava dos bondes e dos trens.

No entanto, o novo modelo também não apresentava qualidade e eficiência em função da pulverização de empresas, pouca qualidade e falta de fiscalização ${ }^{26}$. Com a decadência dos trens e a redução dos serviços de bondes aliada a uma crescente insatisfação popular, era necessário um sistema de transporte que pudesse atender à demanda em expansão e recebesse os passageiros desviados do sistema ferroviário. Novamente foi feita uma clara opção pelos ônibus, tanto nas áreas nobres quanto nas mais pobres da cidade, porém desta vez de uma forma mais organizada. As obras viárias entraram no auge de sua implantação, sendo do agrado de todos. Segundo Duarte ${ }^{27}$ :

O rodoviarismo ou a "febre viária" como chamou ABREU (1987) livrou o poder público de dividir os esforços e recursos entre a rede dos ricos e a dos pobres. Investir em ferrovias, por exemplo, era gastar com um sistema não utilizado pelos estratos mais elevados da sociedade. As ruas e avenidas atendiam, ainda que de forma desigual, reiteramos, às diferentes classes sociais.

A substituição dos bondes por ônibus foi uma política de estado planejada e executada metodicamente pelo governador Carlos Lacerda, de acordo com o mesmo autor, acompanhada de uma ampla intervenção pública no sistema viário intra-urbano - túneis, viadutos e vias expressas.

\footnotetext{
${ }^{26}$ Segundo Ronaldo Goulart Duarte, as queixas eram muitas no final da década de 1950 e a imprensa se referia constantemente às "lotações perigosas" e aos "ônibus assassinos".

${ }^{27}$ DUARTE, à p. 97.
} 
Na década de 1960, foi feita uma grande regulação do sistema de ônibus, micro-ônibus e lotações, concentrando e reordenando os serviços. Inicialmente, eliminaram-se as licenças para permissionários individuais, obrigando sua incorporação às empresas existentes ou forçando a formação de novas empresas, passando, em seguida, à proibição para micro-ônibus e auto-lotações e à obrigatoriedade de substituição dos mesmos por ônibus. Em seguida, foi feita uma reorganização estrutural do sistema de linhas de ônibus da cidade com nova classificação, redistribuição espacial, adoção de numeração indicativa e especificação de padrões operacionais mínimos. Foram impostos prazos para o atendimento desses novos padrões. Finalmente em 1967, um decreto estadual fixou a frota mínima de ônibus em 60 veículos por empresa, de forma que um ano mais tarde ela estava totalmente reorganizada segundo a nova legislação ${ }^{28}$. Os espaços de atuação de cada empresa foram redistribuídos sem grandes conflitos entre os interessados, o que sugere uma forte articulação entre os mesmos.

De acordo com o Plano Diretor de Transportes Urbanos da Região Metropolitana do Rio de Janeiro - PDTU (dados de 2003 e 2004) ${ }^{29}$, o sistema de ônibus evoluiu para desempenhar uma função estrutural, com cerca de 170 empresas operadoras atualmente. São aproximadamente 1.500 linhas em funcionamento na RMRJ - sendo aproximadamente 400 no município do Rio de Janeiro -, com extensões médias de $50 \mathrm{~km}$, considerando os dois sentidos de deslocamento. Praticamente 50\% das linhas apresenta extensão média de mais de 40 km; percursos muito longos que demonstram a função estrutural desse sistema. Adicionalmente, os itinerários das principais linhas de ônibus operam em corredores que dispõem paralelamente de infraestrutura de transporte de massa sobre trilhos.

\footnotetext{
${ }^{28}$ Estado do Rio de Janeiro, Decreto 988/1962, Decreto 1.507/1963, Decreto “N” N.45/1963, Portaria “N” N". 5/1964, Decreto “E” 1482/1967. Mais recentemente em 1981, o Decreto 3.239 concentrou ainda mais o setor estabelecendo como 120 ônibus a frota mínima.

${ }^{29}$ CONSÓRCIO LOGIT - OFICINA - JGP. Plano Diretor de Transporte Urbano da Região Metropolitana do Rio de Janeiro - PDTU. Capítulo 2 - Estrutura do Serviço Atual de Transportes. [S.l.: s.n.], 2004, 51 p. e Capítulo 3 - Prognóstico. [S.l.: s.n.], 2005, 33 p.
} 
O sistema alternativo de transporte por microônibus (vans, kombis e outros), que se iniciou nos anos 1990, vem assumindo nos últimos anos um papel relevante no transporte metropolitano de passageiros e é apenas parcialmente regulamentado pelo Estado e pelo Município do Rio de Janeiro. Este sistema compete com o sistema convencional de ônibus, sendo comum o grande número de linhas coincidentes; apresenta extensões ainda mais longas, em média 76,8 km considerando-se os dois sentidos. Oferece, no entanto, menores tempos de viagem e serviço porta a porta. Utiliza como terminais as imediações dos mesmos terminais do transporte convencional.

Não se tem idéia precisa do número de veículos que operam clandestinamente, sendo que o grau de organização pode ser considerado bastante precário. Vasconcellos e Balassiano ${ }^{30}$ estimam que no ano de 2003 existiam cerca de dez mil veículos em operação na Região Metropolitana do Rio de Janeiro, dos quais aproximadamente seis mil em situação regular.

A matriz de deslocamentos constante do PDTU indica, a partir da pesquisa O-D 2003, que os passageiros transportados pelo transporte alternativo de microônibus (vans, kombis e outros) chegava a 18,2\% do total de passageiros transportados, sendo que os ônibus convencionais, ligações municipais e intermunicipais atingiam 73,6\%.

\subsection{Barcas}

A travessia da Baia da Guanabara começou a ser feita regularmente em meados do século XIX transportando passageiros e carga entre o Rio de Janeiro e Niterói. Várias empresas se

\footnotetext{
${ }^{30}$ VASCONCELLOS S. C. e BALASSIANO R. An integration proposal to the transport system of the city of Rio de Janeiro. [2003] 7 p. Disponível em:

$<$ http://www.codatu.org/english/publication/proceeding/conference/coadatu11/Papers/balassiano.pdf $>$ Acesso em: 22 fev. 2007.
} 
sucederam, algumas ligadas às empresas ferroviárias. A movimentação cresceu sistematicamente durante a primeira metade do século XX e mais rapidamente a partir dos anos 1950, já sob o controle estatal federal, chegando em 1970 a uma movimentação que correspondia ao dobro daquela do ano de 1950, possibilitando a travessia de cerca de 55 milhões passageiros/ano. No início dos anos 1970, o serviço passou para o domínio do Estado do Rio de Janeiro com a criação da CONERJ.

A ligação rodoviária entre Rio de Janeiro e Niterói, através da ponte Presidente Costa e Silva, foi inaugurada em 1974 com o objetivo de permitir a circulação de veículos cuja única alternativa, além do transporte hidroviário, era o longo trajeto através do município de Magé, contornando a Baia da Guanabara. A utilização da ponte não chegou a diminuir a demanda pelo transporte marítimo de passageiros, que continuou intensa no início dos anos 1980 . O sistema de barcas era acessível em termos de tarifa, e seus terminais eram muito bem localizados; ligando o coração das duas cidades.

No entanto, ao longo das duas últimas décadas do século $\mathrm{XX}$ ocorreu uma significativa expansão no fluxo de veículos que cruzam a ponte Rio-Niterói - com um aumento do número de linhas de ônibus interligando os Municípios de Niterói e São Gonçalo, além da Região dos Lagos e Norte Fluminense, ao Rio de Janeiro - resultando numa queda expressiva, 50\%, no número de passageiros transportados pela CONERJ, que não investiu na modernização de seus equipamentos. Em 1998, a CONERJ foi transferida para a iniciativa privada, passando a ser administrada pelo Consórcio Barcas S. A., sob o regime de concessão do direito de exploração de suas linhas regulares pelo período de 25 anos, renováveis. 
Existem hoje dois tipos de serviços: a Linha Social - operada pela Barcas S. A., com três linhas que utilizam barcas convencionais, com extensão total de cerca de $45 \mathrm{~km}$ que, a partir da Praça XV alcançam Niterói, Ilha do Governador e Paquetá - e a Linha Seletiva - duas linhas que utilizam aerobarcos e catamarãs, operada pela Aerobarcos do Brasil Transportes Marítimos e Turismo - Transtur, com 23,5 km de extensão que fazem a ligação Praça Mauá a Niterói, Paquetá e Charitas.

\subsection{Metrô}

Os estudos iniciais para a implantação de um sistema de transporte metroviário ${ }^{31}$ na cidade do Rio de Janeiro datam de 1929. Vários estudos foram feitos, como será detalhado no próximo capítulo, mas foi somente em 1968 que foi elaborado e aprovado o Estudo de Viabilidade Técnica e Econômica do Metropolitano do Rio de Janeiro, elaborado pelo consórcio teutobrasileiro, integrado pelas firmas Companhia Construtora Nacional, Hochtief e Deutsch Eisenbahn Consulting. Recomendou-se então a construção de uma Linha Prioritária ligando a Praça Nossa Senhora da Paz à Praça Saens Peña, passando por Copacabana, Botafogo, Centro e Central, com conclusão prevista para 1975. Seria prolongada até Jacarepaguá, via Méier, até 1990. Recomendava-se também a construção de uma segunda linha que ligaria Pavuna a Niterói, atravessando área pouco ocupada existente entre os dois eixos ferroviários principais na direção noroeste, incluindo Estácio e Carioca como estações de transferência.

A Linha 1, trecho de pouco mais de 4 km, foi inaugurada em 1979, operada pela Companhia do Metropolitano do Rio de Janeiro, vinculada à Secretaria de Estado de Transportes. O sistema permaneceu sob a responsabilidade da Companhia do Metrô-RJ por 19 anos, período em que

\footnotetext{
${ }^{31}$ Atentar para a definição de sistema metroviário como sistema de transporte urbano elétrico, de lata freqüência, independente do restante do tráfego, em via exclusiva, geralmente subterrâneo.
} 
foram construídas e implantadas 15 estações da Linha 1, interligando Botafogo à Tijuca, e 9 estações da Linha 2, do Estácio a Vicente de Carvalho. A Linha 1 foi implantada como um metrô subterrâneo convencional e a Linha 2 como metrô de superfície, Pré-Metrô. Nos anos 1990, era grande a irregularidade na prestação de serviços desse sistema, em especial na Linha 2 - Pré-Metrô, com intervalo crescente entre composições, paralisações por falta de material rodante e outros problemas, sendo o serviço, nestes casos, substituído por ônibus ${ }^{32}$.

A parte operacional do Metrô foi concedida à iniciativa privada em $1998^{33}$ - OPPORTRANS Concessão Metroviária S/A - METRÔ RIO -, concessão válida por um período de 20 anos. Atendendo a compromissos contratuais, foram inauguradas as estações Cardeal Arcoverde da Linha 1, em Copacabana e as estações Irajá, Colégio, Coelho Neto, Acari/Fazenda Botafogo, Engenheiro Rubens Paiva e Pavuna, da Linha 2.

Em 2001, foi criada a SEDUR - Secretaria de Desenvolvimento Urbano do Estado do Rio de Janeiro, à qual passa a estar vinculada a Companhia do Metropolitano. Nesse mesmo ano, foi determinada a cisão da Companhia do Metrô em duas empresas: uma a ser liquidada (onde permanecem os ativos e a relação empregatícia dos funcionários) e a outra que é a responsável pelas atividades de planejamento, projetos e obras de expansão do metrô. A parte ativa da Companhia do Metrô foi, em seguida, substituída pela Companhia de Transportes sobre

\footnotetext{
${ }^{32}$ De acordo com informações constantes na Cronologia do Anuário ANTP dos Transportes Urbanos, 1998, páginas 280 a 283.

${ }^{33}$ Em 27 jan. 1998, o Estado do Rio de Janeiro firmou contrato de concessão para a exploração dos serviços públicos de transporte de passageiros com a Opportrans S. A., que em 05 abr. 1998 assumiu o sistema, numa ação pioneira no Brasil. Segundo MOURTHÉ, A. Metrô do Rio: análise crítica da concessão. Revista dos Transportes Públicos - ANTP. São Paulo, 1999, v 83. p. 57 a 64, essa ação deveria ter provocado uma grande discussão, o que não ocorreu. O processo de concessão ficou protegido por rigorosas cláusulas de sigilo, situação de pouca transparência, muitas vezes alertada por entidades como o Clube de Engenharia, o CREA e o Sindicato dos Metroviários do Rio de Janeiro, dentre outras.
} 
Trilhos do Estado do Rio de Janeiro - RIO TRILHOS ${ }^{34}$, criada também em 2001, por decisão da Assembléia da empresa.

No final de 2002 foi inaugurada a estação Siqueira Campos da Linha 1, aberta ao público em março de 2003. Nesse mesmo ano foi extinta a SEDUR, e a RIO TRILHOS passou a ser um órgão vinculado à Secretaria de Estado de Transportes do Estado do Rio de Janeiro SECTRAN, como foi originalmente a Companhia do Metrô.

A METRÔ RIO implantou nos últimos três anos uma série de percursos de ônibus que alimentam o metrô em algumas estações, de forma a captar mais passageiros para o sistema de metrô, ampliando consideravelmente o alcance do sistema, tornando a operação mais rentável.

Encontram-se hoje em operação os seguintes trechos:

Linha 1 - Siqueira Campos a Saens Pena - 13,9 km de extensão com 17 estações. Permite integração com ônibus operados pela própria METRÔ-RIO em parceria com a RIO ÔNIBUS nas seguintes estações:

Siqueira Campos - duas linhas de ônibus, uma para Gávea e outra para Ipanema;

Largo do Machado - uma linha para o Cosme Velho e

Estácio - quatro linhas: para Muda, para Usina, para Andaraí e para Grajaú.

Permite integração com o sistema de trens de subúrbio na estação Central.

A estação Cantagalo está em operação experimental desde o final de 2006.

Linha 2 - Estácio a Pavuna - 21,7 km de extensão com 16 estações ${ }^{35}$. Também permite integração com ônibus nas seguintes estações:

\footnotetext{
${ }^{34}$ A reorganização gestionária do Metrô foi feita pelos Decretos Estaduais de nos. 27.898 de 9 de Março de 2001, 28.313 de 11 maio 2001 e 32.621, de 01 jan. 2003 e Assembléia da Companhia de 25 maio 2001.
} 
Del Castilho - uma linha para o Fundão, junto a Ilha do Governador e

Coelho Neto - duas linhas, uma para Santa Cruz e uma para Sepetiba.

Permite integração com o sistema de trens de subúrbio nas estações São Cristóvão, Triagem e Pavuna.

O volume de passageiros transportados pelo Metrô ${ }^{36}$ vem aumentando ao longo do tempo, chegando no ano 2000 a um total de cerca de 113 milhões de passageiros transportados. Em 2005 esse número passou para mais de 117 milhões. A linha 1, de Metrô convencional, que atravessa as áreas mais centrais da cidade, atende 73,6\% do total de passageiros transportados em $2005^{37}$, sendo o restante atendido pela linha 2, Pré-Metrô, que chega até Pavuna no limite norte do município, de modo que o sistema serve predominantemente a área central. Ver Ilustração 13 - Rede Metroviária 2007 e Expansão da Rede.

Os projetos de expansão da malha metroviária existentes, mas sem previsão de prazo para implantação, são:

Linha 3 - da estação Carioca, no centro do Rio de Janeiro, inicialmente até Niterói e São Gonçalo, cruzando a baia da Guanabara - trecho em túnel submerso -, até Itaboraí, em superfície, com a utilização de leito ferroviário existente;

Linha 4 - ligando Botafogo à Alvorada na Barra da Tijuca;

\footnotetext{
${ }^{35}$ A estação Estácio permite a integração das duas linhas e está computada no número total de estações em cada linha.

${ }^{36}$ Segundo dados obtidos através da Tabela 1267 - Passageiros transportados no Metrô, segundo as estações e linhas 1995-2005 disponível na página de dados estatísticos da PMRJ

<htpp://www.armazemdedados.rio.rj.gov.br>, acesso em 11 fev. 2007, cujas fontes são: Companhia do Metropolitano do Rio de Janeiro - METRÔ-RJ e Opportrans Concessão Metroviária S.A. - METRÔ-RIO.

${ }^{37}$ Os dados referentes ao ano de 1998 publicados no Anuário ANTP dos Transportes Públicos, 1998, indicam que a proporção de passageiros transportados na linha 1 era de $80,61 \%$ do total. Pode ter havido um aumento real de passageiros transportados na Linha 2.
} 
Linha 5 - ligando o Aeroporto Tom Jobim ao Aeroporto de Santos Dumont, com uma série de trajetos alternativos e

Linha 6 - ligando a Barra da Tijuca ao Aeroporto Internacional Tom Jobim (alternativas 1 e 3) ou à Ilha do Governador (alternativa 2), passando por Duque de Caxias, Madureira e Taquara.

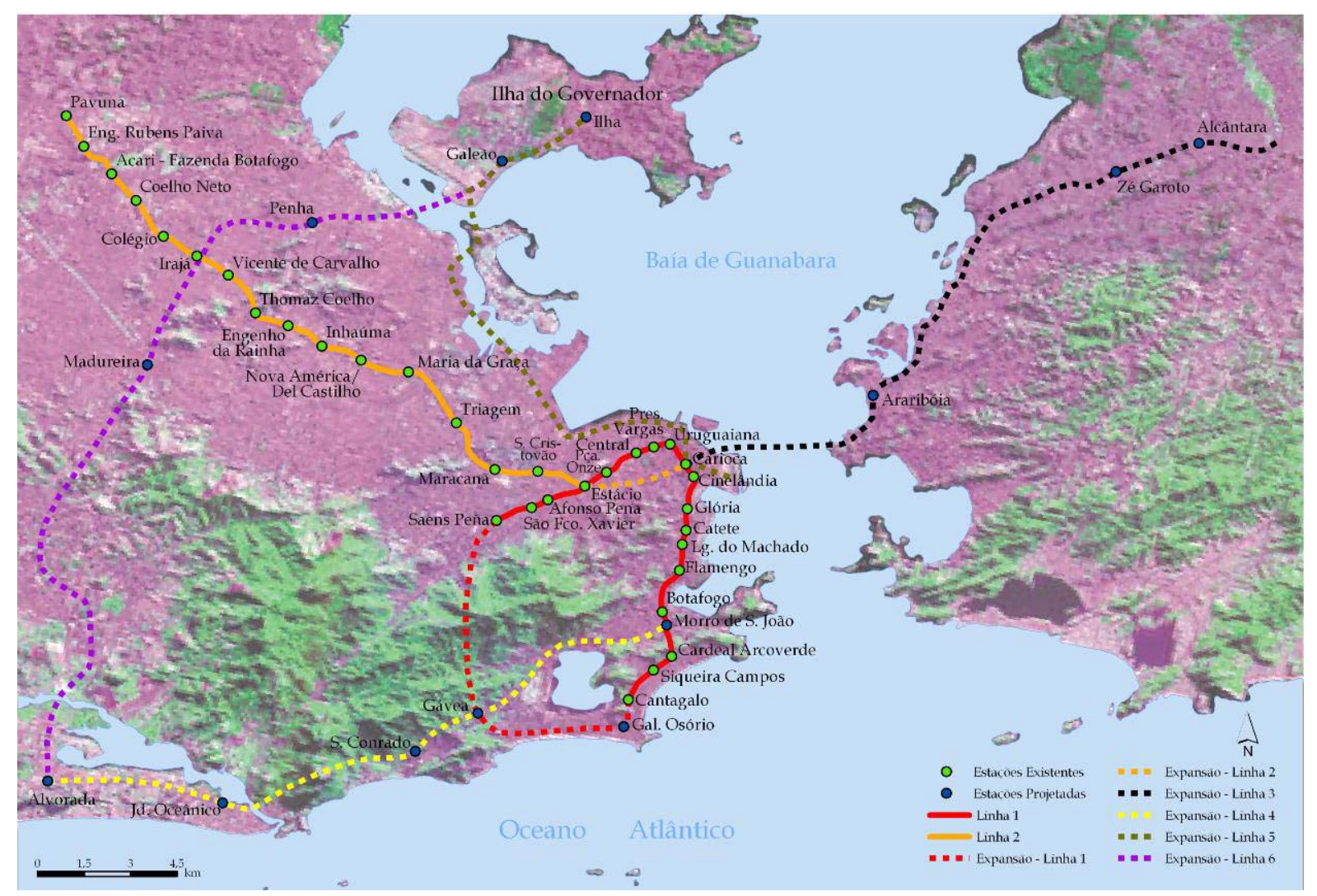

Referência: <http://www.metrorio.com.br>, página oficial do METRÔ- RIO, Metrô do Rio de Janeiro.

\section{Ilustração 13 - Rede Metroviária 2007 e Expansão da Rede}

\subsection{O conjunto dos sistemas de transportes}

A Tabela 7 - Número de Passageiros Transportados por Modalidade/Ano - Rio de Janeiro 1896 a 1920 e Área Metropolitana 1930 a 1970, abaixo apresentada, foi construída a partir das informações constantes do livro já citado "Estrutura Metropolitana e Sistema de Transportes: 
Estudo do Caso do Rio de Janeiro” de Josef Barat e a Tabela 8 - Número de Passageiros Transportados por Modalidade/Ano - Área Metropolitana 1980 a 2005, também a seguir, foi por nós elaborada a partir de pesquisa nas fontes de dados estatísticos da Prefeitura do Município do Rio de Janeiro, no Anuário ANTP dos Transportes Urbanos e na Revista de Transportes Públicos. Não incluem dados sobre número de passageiros transportados por automóveis e táxis e também por ônibus, devido à discrepância de informações entre as várias fontes consultadas ${ }^{38}$. O Gráfico 1 - Evolução dos sistemas de transportes no Rio de Janeiro Períodos Críticos apresenta a evolução do número de passageiros transportados/ano, gerado a partir das Tabelas 7 e 8, onde pode ser observado o comportamento de cada modo de transporte ao longo de mais de um século na cidade do Rio de Janeiro, e serve de subsídio para as considerações sobre o conjunto dos sistemas de transportes, a seguir apresentadas. O Gráfico 1 apresenta também os períodos críticos na prestação dos serviços de transportes públicos no Rio de Janeiro.

Pode-se afirmar que no período de 1930 a 1950, a cidade do Rio de Janeiro teve um equilibrado e adequado sistema de transporte público baseado na rede de bondes, trens de subúrbio e ônibus. O sistema apresentava complementaridade entre os modos - bondes e trens suburbanos como sistemas estruturais e ônibus e ainda parte dos bondes na coleta e distribuição locais. A cidade cresceu, amparada pela expansão do transporte coletivo. Em 1930, o número de passageiros transportados pelos sistemas sobre trilhos alcançava 93,0\%, passando para 83,9\% em 1940 e para 71,5\% em 1950. No entanto, já em 1940 o número de passageiros transportados por ônibus ultrapassou o total transportado por trens.

\footnotetext{
${ }^{38}$ Para compatibilização desses dados seria necessária pesquisa aprofundada junto aos organismos que regulam e/ou operam os sistemas de ônibus municipais e intermunicipais dos vários municípios integrantes da RMRJ, o que foge ao tema deste trabalho de pesquisa, como foi feito sistematicamente por Barat para o período de 1896 a 1970.
} 
Tabela 7 - Número de Passageiros Transportados por Modalidade/Ano - Rio de Janeiro 1896 a 1920 e Área Metropolitana* 1930 a 1970

\begin{tabular}{|c|c|c|c|c|c|c|c|c|c|c|c|c|c|c|c|c|}
\hline \multicolumn{17}{|c|}{ No. DE PASSAGEIROS TRANSPORTADOS (Milhões - Mi) } \\
\hline & \multicolumn{2}{|c|}{1896} & \multicolumn{2}{|c|}{1906} & \multicolumn{2}{|c|}{1920} & \multicolumn{2}{|c|}{1930} & \multicolumn{2}{|c|}{1940} & \multicolumn{2}{|c|}{1950} & \multicolumn{2}{|c|}{1960} & \multicolumn{2}{|c|}{1970} \\
\hline & Mi & $\%$ & Mi & $\%$ & Mi & $\%$ & Mi & $\%$ & Mi & $\%$ & Mi & $\%$ & Mi & $\%$ & Mi & $\%$ \\
\hline $\begin{array}{c}\text { Cidade do Rio de Janeiro / } \\
\text { Região Metropolitana } \\
\end{array}$ & 78,2 & 100,0 & 136,6 & 100,0 & 335,8 & 100,0 & 658,0 & 100,0 & 901,0 & 100,0 & 1265,0 & 100,0 & 1210,0 & 100,0 & 2089,0 & 100,0 \\
\hline BONDES & 72,9 & 93,2 & 112,0 & 82,0 & 283,0 & 84,3 & 506,0 & 76,9 & 634,0 & 70,4 & 686,0 & 54,3 & 361,0 & 29,8 & $* *_{-}$ & - \\
\hline TRENS - Subúrbios & 5,3 & 6,8 & 20,4 & 14,9 & 44,5 & 13,2 & 106,0 & 16,1 & 122,0 & 13,5 & 218,0 & 17,2 & 245,0 & 20,3 & 182,0 & 8,7 \\
\hline METRÔ & - & - & - & - & - & - & - & - & - & - & - & & -- & - & - & - \\
\hline ÔNIBUS & - & - & - & - & 0,6 & 0,2 & 33,0 & 5,0 & 127,0 & 14,1 & 255,0 & 20,2 & 445,0 & 36,8 & 1427,0 & 68,3 \\
\hline AUTOMÓVEIS/TAXIS & - & - & - & - & - & - & - & - & nd & nd & 79,0 & 6,2 & 125,0 & 10,3 & 425,0 & 20,3 \\
\hline BARCAS & - & - & 4,2 & 3,1 & 7,7 & 2,3 & 13,0 & 2,0 & 18,0 & 2,0 & 27,0 & 2,1 & 34,0 & 2,8 & 55,0 & 2,7 \\
\hline
\end{tabular}

* Os dados referentes aos anos 1896, 1906 e 1920 referem-se à cidade do Rio de Janeiro e aqueles relativos aos demais anos refletem a situação da Região Metropolitana, excluídos os municípios de Itaboraí, Maricá e Magé.

** Em 1964 foi extinto o serviço de bondes.

Tabela 8 - Número de Passageiros Transportados por Modalidade/Ano - Área Metropolitana* 1980 a 2005 (não inclui ônibus, automóveis e táxis)

\begin{tabular}{|r|c|c|c|c|}
\hline \multicolumn{7}{|c|}{ No. DE PASSAGEIROS TRANSPORTADOS (Milhões - Mi) } & $\mathbf{2 0 0 0 ^ { * * }}$ & $\mathbf{2 0 0 5}^{* *}$ \\
\hline \multirow{2}{*}{ Região Metropolitana do Rio de Janeiro* } & $\mathbf{1 9 8 0 * * *}$ & $\mathbf{1 9 9 0}$ & $\mathbf{M i}$ & 0,64 \\
\cline { 2 - 5 } & $\mathbf{M i}$ & $\mathbf{M i}$ & 0,81 & 86,11 \\
\hline BONDES & & & 80,51 & 117,67 \\
\hline MRENS - Subúrbios & 185,00 & $82,30^{* * *}$ & 113,02 & 20,45 \\
\hline MARCAS e AEROBARCOS & 20,00 & $92,52^{* * *}$ & 24,95 & \\
\hline
\end{tabular}

* Excluídos os municípios de Itaboraí, Maricá e Magé.

** Dados obtidos da Tabela 440 disponível no site de dados estatísticos da PMRJ www.armazemdedados.rio.ri.gov.br Acesso em 11 fev. 2007.

*** A informação se refere ao ano 1992 obtida a partir dos dados do Anuário ANTP dos Transportes Urbanos 1996.

**** Informações sobre trens, barcas e metrô obtidas em “Estatísticas”, Revista Nacional dos Transportes Públicos -

ANTP, v 16, jun. 1982. p. 131 


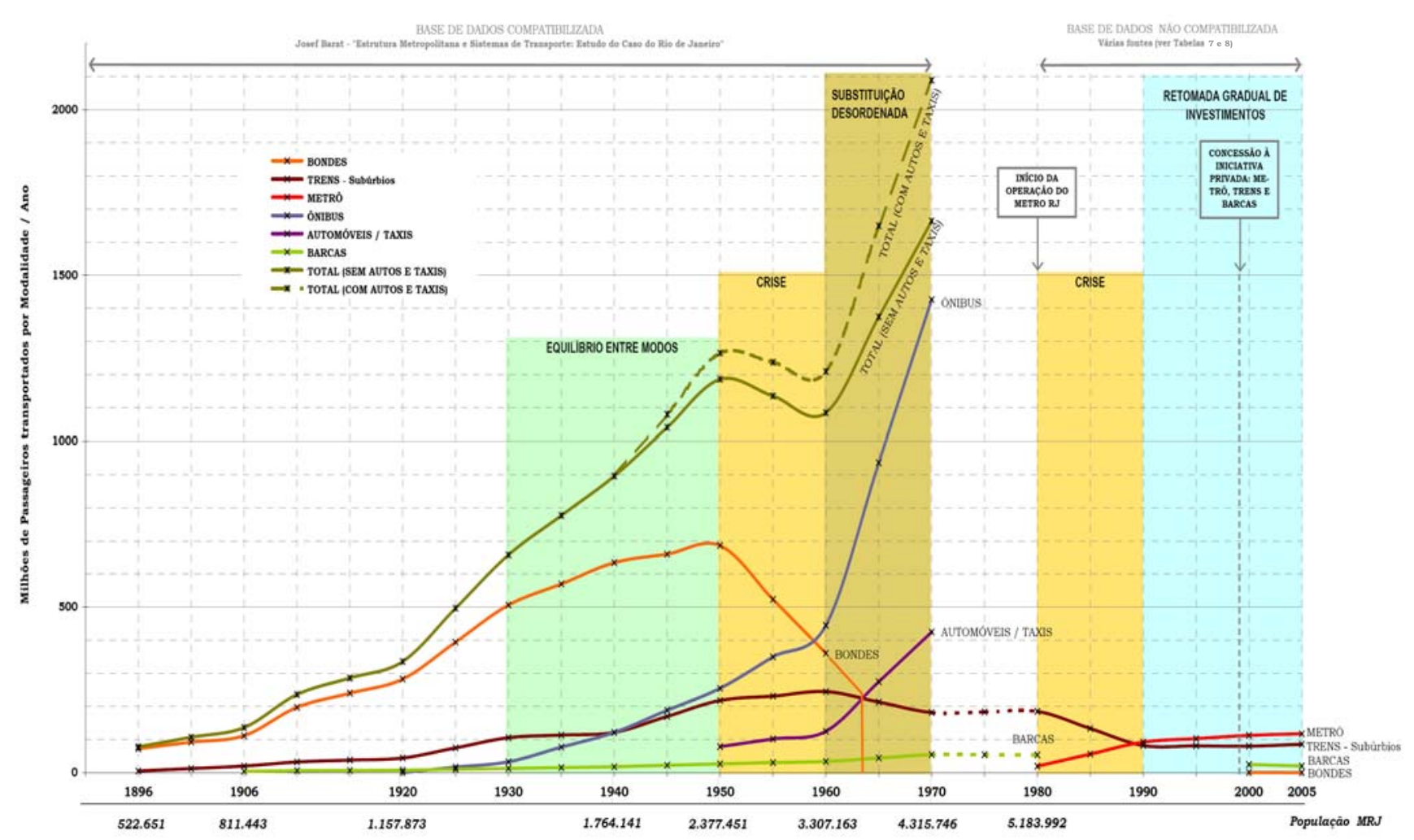

Gráfico 1 - Evolução dos sistemas de transportes no Rio de Janeiro - Períodos Críticos

A partir dos anos $1950^{39}$ a situação se alterou rapidamente com a clara opção pelo meio rodoviário baseado nos ônibus. O número de passageiros transportados por bondes começou a cair rapidamente e aqueles transportados por trens continuou a crescer, porém de forma menos acelerada. Em 1960, o transporte sobre trilhos ainda totalizava 50,1\% dos passageiros transportados naquele ano, sendo os bondes responsáveis por 29,8\% da movimentação de passageiros e os trens por $20,3 \%$. A outra metade se distribuía da seguinte forma: $36,8 \%$ em ônibus, 10,3\% em automóveis e 2,8\% em barcas. Pode-se constatar uma década de crise nos deslocamentos no Rio de Janeiro - 1950 a 1960 - quando se observa que o número total de passageiros transportados no ano de 1960 caiu significativamente, 4,3\%, quando comparado com o mesmo total no ano de 1950, embora a população tenha crescido 33\% nesse período.

\footnotetext{
${ }^{39}$ Segundo Josef Barat, até 1950, o atendimento da demanda pelo transporte coletivo não apresentava grandes problemas, tanto no que se refere ao alcance físico dos sistemas existentes, quanto nas condições de utilização dos veículos.
} 
O rápido crescimento demográfico, associado à ausência de modernização tecnológica ou de melhoria dos sistemas existentes, e a estagnação de investimentos e a conseqüente decadência dos serviços prestados, provocaram, no longo prazo, graves desequilíbrios entre capacidade e demanda, favorecendo a substituição desordenada dos serviços sobre trilhos em detrimento da complementaridade. Privilegiou-se o sistema de ônibus, que é uma solução inadequada para o transporte de grandes massas de passageiros.

Com o crescimento da produção de automóveis, o espaço das vias passou a ser disputado por ônibus, bondes e automóveis. Observa-se, como conseqüência, uma redução da qualidade de vida em geral: congestionamentos, deterioração do uso do solo junto às vias de maior circulação, poluição, destruição dos espaços verdes, dentre outras manifestações.

Os bondes foram finalmente extintos em meados da década de 1960 quando ainda transportavam, como já vimos, um número expressivo de passageiros, 18\% do volume total transportado. Essa drástica extinção não permitiu um ajuste racional entre os modos de transporte, de forma que não se explorou a possibilidade de transformação de algumas linhas de bondes em pré-metrôs, perdendo-se uma oportunidade única de se privilegiar o transporte de massa. O número de passageiros transportados por ônibus ultrapassou o número de passageiros transportados por trilhos já no início da década de 1960, chegando a um crescimento de $220 \%$ ao final da década. Em 1970, aproximadamente 68,3\% da população utilizava ônibus enquanto que apenas $8,7 \%$ era transportada pelos trens de subúrbios. O número de automóveis e táxis cresceu muito no período, assim como o transporte irregular em lotações; quase $90 \%$ da população usava veículos sobre rodas. 
O sistema de trens perdeu espaço para os ônibus e entrou em declínio acentuado a partir dos anos 1960 chegando ao menor número de passageiros transportados, num período de quase 80 anos, no final da década de 1990. Em 1998, a exploração do sistema ferroviário de passageiros de subúrbios foi concedido à iniciativa privada. A partir de então, com a reorganização gradativa e a injeção de investimentos o sistema começa a se recuperar, embora muito lentamente. O uso dos meios rodoviários - automóveis, táxis e lotações, ônibus e microônibus - continuou a crescer, reorganizado nas décadas de 1960 e 1970, embora a expansão do espaço viário não tenha acompanhado o crescimento do transporte rodoviário. Entram em cena os microônibus (vans, kombis e outros), que competem com os sistemas estruturais e com os ônibus, não cumprindo o papel de alimentadores desses sistemas, no que seriam de grande utilidade, segundo Vasconcellos e Balassiano ${ }^{40}$, que demonstram, através de um estudo de caso na Ilha do Governador que, com a utilização desse modo de transporte de maneira complementar aos sistemas estruturais, haveria uma redução considerável nos tempos de espera pelo transporte, bem como no consumo de combustíveis e custos operacionais.

É na fase que pode ser considerada a mais crítica dos serviços de transportes públicos, entre 1950 e 1970, que a idéia de construir um sistema metroviário no Rio de Janeiro começou a ganhar corpo. No entanto, é só na década de 1990 que o volume de passageiros transportado pelo Metrô passou a ter importância, ultrapassando o volume de passageiros transportados pelos trens, mas ainda muito aquém daquele transportado pelos ônibus e com uma abrangência geográfica muito limitada.

Atualmente, segundo o PDTU, o serviço de transporte coletivo da RMRJ caracteriza-se pela falta de integração e de complementaridade entre os modos existentes. A inadequada gestão

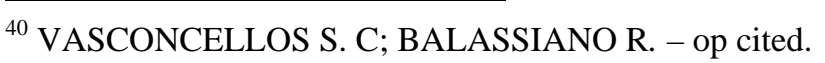


pública dos serviços permitiu serviços irregulares e não disciplinou os serviços existentes, no sentido de sua complementaridade. Os sistemas estruturais - trens, metrô e barcas continuam hoje a sofrer a concorrência de linhas municipais e intermunicipais de ônibus e de transporte alternativo de kombis e vans. O conjunto das modalidades rodoviárias continua a cumprir um papel que deveria ser do sistema de maior capacidade.

A Região Metropolitana do Rio de Janeiro apresenta, além dos problemas característicos da oferta - tais como falta de investimentos, inadequada distribuição modal, e outros acima descritos - características de uso do solo que agravam a situação de saturação da movimentação de seus habitantes. Observa-se uma exagerada convergência para a zona central, forte crescimento vertical, concentração da oferta de serviços básicos e limitações de relevo que dificultam uma expansão horizontal mais equilibrada. Os condicionantes físicos restringem a ligação Zona Norte - Zona Sul através do Centro a um corredor de largura limitada. A ausência de vias de contorno intensifica a movimentação em determinados eixos e a expansão viária não acompanha a demanda ${ }^{41}$. O eixo rodoviário avenida Brasil, que parte do Centro em direção aos subúrbios e à Baixada Fluminense é único e apresentava, já no início dos anos 1980, o maior carregamento de veículos da região metropolitana. Paralelo à linha férrea, este eixo saturado testemunha ainda hoje o uso ineficiente do sistema de trens de subúrbios que, se operado adequadamente, poderia ter sua movimentação substancialmente aumentada. O transporte coletivo em ônibus é lento, ineficiente e em condições precárias de manutenção para o atendimento da maior parte da população.

O PDTU preconiza que a superação dos problemas do transporte coletivo da RMRJ passa pela implantação de uma organização do transporte na RMRJ, a partir da afirmação de que, ao se

\footnotetext{
${ }^{41}$ Nos anos 1990 as ligações Zona Norte/Zona Sul receberam investimentos, com a construção da Linha Vermelha e da Linha Amarela, esta última funcionando como via de contorno ao centro.
} 
comparar a rede existente e as linhas de desejo, pode-se concluir que a RMRJ dispõe de infraestrutura instalada capaz de atuar como um sistema efetivamente estrutural. Porém, para que o sistema sobre trilhos cumpra essa função, será necessária uma reorganização das linhas de transporte rodoviário associada a um aumento da capacidade nos sistemas ferroviário e metroviário. Medidas de priorização do transporte coletivo (tipo corredores exclusivos) e implantação de tecnologias mais modernas de sistemas de transporte de massa, bem como a efetiva integração tarifária entre modos, deveriam ser perseguidas como forma de racionalização e otimização dos sistemas. E acrescenta ainda que:

[...] caso não sejam implementadas melhorias nos horizontes de curto e médio prazos, em função do crescimento esperado para as viagens em transporte coletivo e automóvel particular, os níveis de serviço deverão entrar em processo de degradação de forma bastante acentuada.[... $]^{42}$

A matriz de passageiros transportados apresentada pelo PDTU, elaborada a partir da pesquisa O-D 2003 e de dados das prefeituras, indica que o total de viagens na RMRJ é de 9,2 milhões de passageiros/dia, sendo seis milhões pagantes e 3,2 milhões gratuitos e alternativos (microônibus - vans, kombis e outros). Desse total, 58,7\% são passageiros dos ônibus municipais, 14,9\% dos ônibus intermunicipais, 3,4\% dos trens, 4,0\% do sistema de Metrô, 0,9\% dos barcos e 18,2\% são passageiros do sistema alternativo.

Corroborando o diagnóstico mais recente do PDTU em 2004, já em 1990, os operadores de transportes rodoviários constatavam que existia o caos nos transportes públicos na RMRJ e que a complementaridade modal seria fundamental para a organização dos transportes públicos na RMRJ. Através da “Carta do Rio de Janeiro - Conclusões do $2^{\circ}$. Encontro dos Transportadores de Passageiros do Rio de Janeiro"43 reconhecem a necessidade de

\footnotetext{
${ }^{42}$ CONSÓRCIO LOGIT - OFICINA - JGP. Plano Diretor de Transporte Urbano da Região Metropolitana do Rio de Janeiro - PDTU. Capítulo 3 - Prognóstico. [S.l.: s.n.], 2005, 33 p., à p. 33.

${ }^{43}$ FETRANSPOR - Federação das Empresas de Transportes Rodoviários do Leste-Meridional do Brasil. Carta do Rio de Janeiro - Conclusões do $2^{\circ}$. Encontro dos Transportadores de Passageiros do Rio de Janeiro. In:

Revista dos Transportes Públicos - ANTP, 1990, V 50. p. 79-83. Publicada originalmente em todos os jornais
} 
recuperação dos serviços ferroviários suburbanos, ampliação da rede de Metrô, melhor utilização do transporte marítimo além da ampliação das vias rodoviárias, assegurando faixas seletivas para os ônibus. Existe um consenso sobre a questão, indicando a necessidade de planos de transporte de massa abrangentes, tanto no que se refere à extensão territorial, como quanto à necessidade de contemplar todos os modos de transporte e dar ênfase à sua complementaridade ${ }^{44}$.

Finalmente, em termos espaciais, a Região Metropolitana do Rio de Janeiro liga-se ao resto do país através de três eixos rodoviários: um na direção de São Paulo, outro na direção de Belo Horizonte e pela ligação Norte-Sul da BR-101, que cruza a cidade paralelamente à orla marítima. São estradas mantidas em razoável estado de conservação. O sistema de trens unindo a cidade a outras capitais é principalmente utilizado para o transporte de carga, sendo muito pequeno o número de passageiros, quando comparado ao transporte rodoviário.

O sistema rodoviário secundário do Estado do Rio de Janeiro tem características técnicas que ficam muito aquém das necessidades da circulação de veículos, sendo ainda muito mal conservado, dificultando seriamente a acessibilidade de várias zonas do interior fluminense, que se encontram a curtas distâncias dos três eixos principais. A área de maior acessibilidade da região é o fundo da Baia da Guanabara, no seu lado Oeste, próxima aos eixos rodoviários que levam a São Paulo e a Belo Horizonte e à via de contorno que passa por Magé.

\footnotetext{
de grande circulação do Estado do Rio de Janeiro em 20 out. 1990, publicada originalmente em todos os jornais de grande circulação do Estado do Rio de Janeiro em 20/10/1990.

${ }^{44}$ SCHOPPA, R. F. Transporte Urbano na Região Metropolitana do Rio de Janeiro: caos ou integração. Revista dos Transportes Públicos - ANTP, São Paulo 1993, v 61. p. 59-78.
} 


\subsection{Planos e projetos de transportes urbanos elaborados}

Cabe reforçar a idéia de que a cidade contou com estudos e planos relativos aos transportes urbanos desde 1926, com o Plano Agache, que apresentava uma discussão sobre o sistema viário da cidade, alertando para a necessidade da implantação de um sistema de transporte rápido de massa, do tipo Metrô e de um sistema adequado de ligações ferroviárias para os subúrbios, bem como transporte rápido na baía da Guanabara. A maior parte das recomendações desse plano não foram implementadas, mas tiveram, como já vimos, o grande mérito de enxergar a cidade como um todo e mostrar aos governantes a necessidade de atuação através de ações mais abrangentes e complexas.

Nas três décadas seguintes, muitos estudos foram feitos, todos porém, de natureza setorial e mais especificamente sobre transporte ferroviário. Muitos recomendavam um sistema de Metrô.

Em 1965, a CEDUG - Comissão Executiva para o Desenvolvimento Urbano da Guanabara, do governo Carlos Lacerda, recebeu o Plano de Desenvolvimento Urbano da Guanabara, encomendado a um consultor internacional, a Doxiadis Associates. O Plano apresenta uma visão extensiva dos problemas da cidade e propõe uma organização territorial ancorada numa malha viária projetada que se estende por todo o território municipal. Este estudo alerta para a necessidade de uma reflexão mais abrangente do setor dos transportes e, mais especificamente, para a necessidade de um plano diretor de transporte a ser integrado ao plano de desenvolvimento. Contém o esboço de um estudo de transportes que chega a classificar funcionalmente as vias urbanas, suburbanas e interurbanas em expressas, arteriais, coletoras e locais. Projeta o número de veículos, baseando-se em tendências históricas, e propõe um 
sistema ambicioso de vias expressas num padrão internacional de rede rodoviária - 760 km para uma população de 8,4 milhões de habitantes e uma frota de automóveis de 1,35 milhões, cerca de 6,2 hab./automóvel. Chega a recomendar um sistema de Metrô nos dois corredores de maior intensidade de tráfego, porém a preocupação principal do Plano Doxiadis é a malha de vias e o transporte individual por automóveis. O Plano Doxiadis não foi adotado oficialmente pelo próprio governo que o solicitara e os governos seguintes o ignoraram.

Os estudos que se seguiram nos anos seguintes, e que descrevem a situação dos transportes no Rio de Janeiro, estão ligados à implantação de grandes obras e propõem algumas soluções de grande magnitude, como por exemplo, o Estudo de Viabilidade da Ponte Rio - Niterói e o Estudo de Viabilidade Técnica e Econômica do Metrô - RJ, ambos realizados em 1968. O primeiro estudo, encomendado diretamente pela esfera federal, através do Ministério dos Transportes, a quatro consultoras, indica o local e tipo de ligação rodoviária mais viável entre o Rio de Janeiro e Niterói. Não apresenta levantamentos e pesquisas específicas, utilizando-se dos dados sócio-econômicos disponíveis. Prevê um cenário pessimista para a Guanabara, antevendo seu esvaziamento econômico, projetando porém, o crescimento da frota de veículos de maneira bastante otimista.

O estudo que recomenda o Metrô - RJ em 1968 foi contratado pelo Governo do Estado da Guanabara com o Consórcio Companhia Construtora Nacional, Hochtief e Deutsch Eisenbahn Consulting (Deconsult), após licitação pública internacional. Um conjunto de dados primários foi recolhido referente à origem e destino dos deslocamentos, desejos de viagem, número de passageiros transportados, frota de veículos, além das informações sócio-econômicas e de uso do solo, projetando-se então a demanda para um horizonte de 20 anos, para vários cenários de desenvolvimento econômico, utilizando a metodologia clássica dos modelos a quatro etapas. 
O estudo recomenda uma linha prioritária definida no corredor da maior demanda de transporte coletivo - 1.500 .000 passageiros/dia -, acreditando que a modernização do sistema ferroviário e melhorias no sistema de ônibus não seriam suficientes para atender as demandas do ano 1990.

As projeções dos três estudos realizados na década de 1960 se mostraram sempre aquém da realidade constatada nos anos 1970 e 1975, no que se refere à frota de automóveis e à relação entre número de habitantes e número de automóveis.

Os diagnósticos ou planos de transporte produzidos na década de 1970 foram realizados pela Secretaria de Estado dos Transportes e pela Cia. do Metropolitano - RJ, destacando-se o Plano de Ação Tarifária e o PIT - Plano Integrado de Transportes do Metrô RJ (1975-1979). Em seguida, foram feitos o Plano Jaime Lerner (1984), PTM - Plano de Transporte de Massa - (1990-1995) e mais recentemente o PDTU - Plano Diretor de Transporte Urbano da Região Metropolitana do Rio de Janeiro (2004), elaborado pelo Consórcio Logit - Oficina - JGP para a CENTRAL SA - Companhia Estadual de Engenharia de Transportes e Logística e SECTRAN - Secretaria de Transportes do Estado do Rio de Janeiro.

O PTM - Plano de Transporte de Massa tem abrangência metropolitana e propõe a implantação de uma rede básica de transporte coletivo e a integração modal, destacando-se a extensão metroviária, implantação do sistema busway - corredor de trem metropolitano Niterói-São Gonçalo e terminais de integração. O PDTU, como já vimos, elaborou pesquisa O-D (2003) e a partir de estudos relativos a todos os modos de transporte em operação na Região Metropolitana, conclui que a região possui uma infra-estrutura de transportes coletivos 
instalada, mas que a organização e gerência dos serviços carecem de ações de integração. Este plano ainda classifica e nomeia os principais corredores viários ${ }^{45}$.

Outros estudos, feitos ao longo do tempo, num período de pelo menos três décadas, apontam soluções e até mesmo projetos específicos para sistema viário e para a gestão dos serviços de transportes coletivos, sendo que merecem destaque os seguintes:

Anel Viário - abrangência município do Rio de Janeiro - conjunto de linhas poli-cromáticas para ligações transversais;

Projeto Rio Bus - abrangência município do Rio de Janeiro - diretrizes para reorganização do sistema de transporte público, envolvendo um sistema tronco-alimentador e redução do número de linhas de ônibus de 400 para 158, em especial na Ilha do Governador e Deodoro;

Semi anel ou Arco Rodoviário - arco norte - abrangência RMRJ;

Ligação com o Porto de Sepetiba - aumento de capacidade da BR-101;

\footnotetext{
${ }^{45}$ Principais corredores viários: Corredor 1 - Linha Vermelha - conexão Centro-Baixada Fluminense; Corredor 2 - Av. Ayrton Senna / Linha Amarela - conexão Barra da Tijuca - Linha Vermelha, na altura da Cidade Universitária - Ilha do Fundão; Corredor 3 - Av das Américas - conexão Barra da Tijuca - Recreio dos Bandeirantes; Corredor 4 - Auto-estrada Lagoa-Barra - conexão Zona Sul - Barra da Tijuca; Corredor 5 - Av. Niemeyer - Leblon - São Conrado, auxiliar ao corredor 4; Corredor 6 - Perimetral (Av Juscelino Kubitschek) no centro, via elevada sobre a Av. Rodrigues Alves, uma das principais ligações entre a Av. Brasil e o centro; Corredor 7 - Viaduto Eng. Freyssinet - Túnel Rebouças - Centro - Rio Comprido até a Lagoa; Corredor 8 Viaduto São Pedro e São Paulo - Túnel Santa Bárbara - Rua Pinheiro Machado - conexão Zona Portuária, Zona Norte, Centro, Catumbi e Laranjeiras; Corredor 9 - Av. Brasil - conexão Zona Norte e Oeste com o Centro; Corredor 10 - São Clemente - Voluntários da Pátria - Jardim Botânico - estrutural na Zona Sul; Corredor 11 Barata Ribeiro - Nossa Senhora de Copacabana - estrutural na Zona Sul; Corredor 12 - Visconde de Pirajá General San Martim - estrutural na Zona Sul; Corredor 13 - 24 de Maio - Marechal Rondon - estrutural no Engenho Novo, São Francisco Xavier e Méier - grande parte coincidente com o sistema ferroviário; Corredor 14 - Conde de Bonfim - Haddock Lobo - Dr. Stamini - Heitor Beltrão - estrutural na Tijuca; Corredor 15 - Barão de Mesquita - Barão de Bom Retiro - estrutural no Grajaú e Andaraí; Corredor 16 - 28 de Setembro - Teodoro da Silva - estrutural em Vila Isabel; Corredor 17 - Av. Maracanã - conexão Tijuca - Centro; Corredor 18 - Av. São Luis Gonzaga - estrutural em São Cristóvão; Corredor 19 - Av. Presidente Vargas - estrutural no Centro; Corredor 20 - Av. Rio Branco - estrutural no Centro; Corredor 21 - Av. Rodrigues Alves - conexão Baixada Centro; Corredor 22 - Av. Infante Dom Henrique - Aterro do Flamengo - conexão Centro - Zona Sul.

Demais ligações estruturais: Via Dutra - BR 116 - ligações intermunicipais e com Rodovia sentido São Paulo; Rodovia Washington Luís - BR-040 - ligação Rio de Janeiro - Petrópolis - ligações intermunicipais e região serrana; Ponte Presidente Costa e Silva - Ponte Rio - Niterói - ligação com o lado oposto da Baia de Guanabara e com o Norte do estado; Av. Presidente Kennedy - ligação com a Rod. Washington Luís; BR-101 Rio-Santos ligação com os municípios Oeste e Sul do estado; Gentil de Moura - Marechal Alencastro - ligação de Deodoro com os municípios vizinhos; Via Light - ligação com os bairros vizinhos ao subúrbio da Leopoldina e municípios ao Norte da RMRJ.
} 
Corredores Transversais Metropolitanos - com tratamento especial para o transporte coletivo por ônibus: T1 - Túnel Santa Bárbara, T2 - Túnel Rebouças, T3 - Mangueira, T4 Ilhas/Tijuca, T5 - Barra/Penha, T6 - Av. Brasil, T7 Transbaixada e T8 - Baixada/Zona Oeste; Sistema Hidroviário - implantação de linhas no interior da Baia da Guanabara - ligando a Praça XV a Cocotá e São Gonçalo, operação hovercraft entre Praça XV e a Barra da Tijuca, Praça XV - Gramacho, contornando a Ilha do Governador e a implantação de catamarãs Galeão, Santos Dumont, Marina e Botafogo;

Sistema Ferroviário - revitalização dos ramais existentes com aumento de capacidade;

Sistema Metroviário - implantação da Linha 3;

VLT - Veículo Leve sobre Trilhos - em meados da década de 1990, num esforço de continuar a implantação de sistemas sobre trilhos, porém com custos mais baixos, foram feitos estudos para a implantação de um VLT indicando a sua viabilidade, através de parceria público-privada, para uma primeira linha em via segregada, com algumas passagens de nível, ligando Cidade de Deus a Madureira na zona Oeste do município do Rio de Janeiro ${ }^{46}$.

No que se refere à gestão dos sistemas de transportes públicos na RMRJ, pode-se observar que, ao longo do tempo, órgãos da três esferas de governo atuaram na região. No início da década de 1980, época de grande interesse para este trabalho, ligados diretamente à União, estavam presentes a RFFSA - Rede Ferroviário Federal SA (na execução de obras e operação), a EBTU - Empresa Brasileira de Transportes Urbanos e o GEIPOT - Grupo Executivo de Integração da Política de Transportes (no planejamento, estudos e recomendações). Na alçada estadual, estavam a CONERJ - Companhia de Navegação do ERJ, a CTC - Companhia de Transportes Coletivos do ERJ, o METRÔ - Companhia do Metropolitano do Rio de Janeiro e o DTC - Departamento de Transportes Concedidos, que

${ }^{46}$ GONÇALVES, Â. F. M.; PORTO JÚNIOR, W. Avaliação de alternativas físicas e operacionais para o projeto do sistema VLT-Rio com o emprego do simulador SIMVLT. In: Revista dos Transportes Públicos - ANTP, v 70, p. 73-85, 1996. 
controlava as empresas privadas de ônibus. O controle de segurança do tráfego urbano era feito pelo DETRAN - Departamento de Trânsito do ERJ e a implantação/operação dos terminais rodoviários e intermodais de passageiros pela CODERTE - Companhia do Desenvolvimento Rodoviário e Terminais do ERJ (planejamento, controle e fiscalização de toda a operação de ônibus intermunicipal), órgãos vinculados à SECTRAN - Secretaria de Transportes. O DER - Departamento de Estradas e Rodagem do Estado do Rio de Janeiro, no que se refere a trechos de estradas, e as Secretarias Municipais e os Departamentos e Serviços da Prefeitura participavam da abertura do sistema viário, da manutenção de vias e outros serviços.

Recentemente, observa-se um direcionamento no sentido da melhoria e integração na gestão dos transportes urbanos da região com a criação da Agência Metropolitana de Transportes Urbanos - AMTU, em Janeiro de $2007^{47}$, que reúne representantes das prefeituras da Região Metropolitana e de operadores do sistema de transportes - METRÔ RIO, SUPERVIA, BARCAS S/A, TRANSTUR e FETRANSPOR. Tem por objetivo propor estudos e soluções para a melhoria do transporte urbano. Na primeira reunião, em Março de 2007, dentre os vários assuntos discutidos destacam-se as propostas de criação de Câmaras Técnicas para tratar e encontrar formas de implementação dos seguintes itens: corredor rodoviário T5 ligação Barra/Penha (corredor segregado com 28 km de extensão para ônibus bi-articulado e terminais); corredor rodoviário de Niterói; linha 3 do Metrô (Centro - Itaboraí); Bilhete Único; atualização do PDTU e implantação do Observatório de Políticas Públicas de Transporte. A segunda reunião, Abril 2007, tratou do Arco Rodoviário - corredor logístico -; planos de expansão do Metrô e da SUPERVIA e um modelo para o funcionamento e gestão do transporte alternativo.

\footnotetext{
${ }^{47}$ A AMTU já existia junto à SECTRAN, funcionando apenas como órgão assessor da Secretaria sem competência específica de integração e coordenação operacional dos diversos modos de transportes.
} 
Pode-se observar um grande descompasso entre a elaboração de um número significativo de planos de transportes urbanos, que incluíram recomendações de integração e projetos específicos, e a situação dos deslocamentos metropolitanos. Nos dias de hoje, o número de deslocamentos por transporte sobre trilhos, de natureza estrutural, corresponde a cerca de um quinto do número de deslocamentos possibilitados por esses modos no ano de 1950, início do processo de substituição por autos, ônibus e vans, quando a população do município chegou a mais que duplicar em valor absoluto e a quadruplicar considerando-se a RMRJ.

O esforço mais recente de compreensão e planejamento de transportes, o PDTU (2004), conclui que a infra-estrutura de transportes coletivos existe, mas que está mal organizada e mal gerida. Podemos acrescentar ainda que, embora existam, esses grandes corredores infraestruturais estão sucateados enquanto estruturas físicas e enquanto material rodante e que todo o conjunto vem sendo gerido de acordo com a lógica de cada sistema em particular, o que contribui para uma situação que pode ser considerada muito inadequada apesar da retomada gradual de investimentos na última década, com a concessão à iniciativa privada dos trens e do Metrô.

Finalmente, também pode ser observado que o período de maior afluxo de idéias e iniciativas para a implantação de um sistema metroviário para a cidade se deu no período de 1960-1970 época de substituição desordenada dos meios ferroviários pelos meios rodoviários -, e que as decisões tomadas não o foram no sentido de reorientar a oferta para atender às necessidades efetivas por deslocamentos de massa, mas sim para se construir um sistema de Metrô isolado e de pouca abrangência espacial e baixo número de passageiros transportados. A substituição de modos ocorria sem planejamento. 
CAPÍTULO 05 


\section{DA IDÉIA À REALIZAÇÃO DO METRÔ-RJ}

A apresentação de idéias para a implantação de um sistema metroviário para acidade do Rio e Janeiro se deu durante um período de cerca de 40 anos - 1927 a 1968 - (50 anos, se considerarmos a breve notícia de uma primeira idéia em 1918). As principais propostas estão descritas a seguir, indicando seus proponentes, patrocínio e características técnicas básicas, além dos traçados dos estudos mais relevantes. Os esforços institucionais que culminaram na licitação internacional que selecionou o Estudo de Viabilidade CCN-Hochtief-Deconsult, que veio a ser a base para a decisão e que foi parcialmente implantado, também estão expostos neste capítulo, assim como é apresentada uma descrição pormenorizada desse estudo.

\subsection{As principais propostas}

Como já apresentado no Capítulo 3, em 1927, a Prefeitura do Distrito Federal contratou o urbanista francês Alfred Agache para elaborar o relatório "Cidade do Rio de Janeiro Extensão, Remodelação, Embelezamento e Organização, projetadas na Administração Prado Junior”, que continha uma série de propostas de estruturação urbana, organizadas em vários temas sendo os principais: circulação, higiene e estética ${ }^{1}$. O relatório, elaborado no período de 1928 a 1930, previa importantes melhorias no sistema viário e sugeria a implantação de um sistema de transporte rápido de massa. Nas palavras de Maria Lais Pereira da Silva, $1992^{2}$, os quatro pontos principais abordados por Agache para a reorganização espacial da cidade eram:

1. Necessidade de suprimir a maior parte dos bondes que estorvam a circulação e cuja velocidade não satisfaz mais.

\footnotetext{
${ }^{1}$ REIS, J. de O. O Rio de Janeiro e seus Prefeitos: Evolução Urbanística da Cidade. Prefeitura da Cidade do Rio de Janeiro, Rio de Janeiro, 1977. 167 p.

${ }^{2}$ SILVA, M. L. P. Os Transportes Coletivos na Cidade do Rio de Janeiro: Tensões e Conflitos. Prefeitura da Cidade do Rio de Janeiro, Secretaria Municipal de Cultura, Turismo e Esportes, coleção Biblioteca Carioca, v 20, 1992. 177 p., à página 80 .
} 
2. Necessidade de artérias principais que penetrem até o centro da cidade.

3. Criação de vias de comunicação com um certo número de bairros excêntricos.

4. Construção de uma rede metropolitana de transportes permitindo o tráfego rápido.

Agache defendia a idéia de investimentos na melhoria do sistema ferroviário existente e sua transformação em transporte rápido na forma de um sistema de metrô aéreo ou subterrâneo. Desta forma, seria possível solucionar com um transporte eficiente os problemas de deslocamento da população trabalhadora e os problemas de congestionamento do centro, ao se substituir os bondes. Nas áreas centrais o sistema de metrô seria subterrâneo, e na direção dos bairros litorâneos seria aéreo, construído junto aos morros.

O Plano Agache foi o primeiro plano extensivo para o Rio de Janeiro - trouxe a noção de urbanismo e de discussão da cidade - distinguindo-se da proposição de medidas pontuais apresentadas nas décadas anteriores ou de medidas essencialmente cirúrgicas do Prefeito Pereira Passos, na primeira década do século XX. O plano não foi adotado oficialmente e suas propostas não tiveram continuidade nas administrações seguintes, servindo, no entanto, como referência para as propostas que se seguiram. A administração intervencionista do Prefeito Adolfo Bergamini, conseqüência da Revolução de 1930, a princípio contestou esse plano, vindo porém a aprová-lo após análise de uma comissão especial de investigação, chegando a criar a Comissão do Plano da Cidade para a elaboração e acompanhamento dos estudos urbanísticos que se seguiram.

Anteriormente ao Plano Agache, no âmbito das idéias gerais e dissociado de uma visão geral da cidade, o engenheiro e conselheiro Álvaro Joaquim de Oliveira apresentou em 1911 requerimento ao Conselho Municipal acompanhado do projeto de um audacioso trem subterrâneo, partindo da Avenida Rio Branco e acompanhando o eixo da EFCB para ligar o centro da cidade ao bairro de Cascadura. A idéia foi rejeitada nas comissões do Conselho, 
mas voltou a ser apresentada através do Clube de Engenharia em 1915, sendo mais uma vez rejeitada pelo mesmo Conselho em $1918^{3}$.

Ainda no final da década de 1920, época em que se construíram metrôs em diversas cidades do mundo, no Rio de Janeiro, a iniciativa privada - através da The Rio de Janeiro Tramway Light and Power Co., de capital inglês, tentou associar-se à Prefeitura para empreender a substituição das linhas de bonde mais carregadas do centro da cidade por uma rede ferroviária subterrânea. O Memorial da Light ${ }^{4}$, de 1929, descrevia a cidade do Rio de Janeiro como uma metrópole de 1.600 .000 habitantes, servida por uma extensão de 523 km de linhas de bonde unificadas. Propunha uma linha de Metrô total ou parcialmente subterrânea num trecho curto - cerca de 12,5 km - do Botafogo ao Colégio Militar, passando pelo Catete, Glória, Largo da Lapa, Avenida Rio Branco, Mangue e Praça da Bandeira, praticamente coincidente com o trecho posto em operação no início dos anos 1980, e ainda duas galerias subterrâneas para tráfego de bondes, uma na Rua da Carioca e outra na Rua Sete de Setembro, com o objetivo de aliviar interseções importantes, ligando o Campo de Santana à estação das barcas. Através de uma partição de responsabilidades, a construção seria feita pela Prefeitura e a companhia concessionária do serviço, a própria Light, instalaria e operaria o sistema e as oficinas, além de continuar com a operação da rede de bondes, unificada e eletrificada. Essa mesma concessionária operaria a rede de ônibus em expansão, complementar ao sistema sobre trilhos, numa ação planejada e integradora dos meios, reforçando ainda mais a situação monopolista da empresa. Tendo em vista que, historicamente, as companhias de bonde no Rio de Janeiro se adiantaram à demanda, abrindo diversas áreas ao desenvolvimento urbano, pode-se supor que, além do interesse em manter o monopólio dos transportes coletivos na

\footnotetext{
${ }^{3}$ J. F. G. O Longo Caminho Subterrâneo. Jornal do Brasil, de 17 jun. 1970.
} 
cidade, a Light vislumbrasse uma valorização imobiliária ao longo do traçado da rede subterrânea, o que geralmente ocorre com a implantação de infra-estruturas de transportes.

Agache chegou a comentar a proposta da Light, afirmando que ela tratava do mínimo indispensável para garantir o transporte dos atuais passageiros dos bondes, sem apresentar soluções para os problemas de deslocamentos do restante da cidade, como seu plano preconizava. Embora com algumas divergências entre as propostas, tanto de conceito como de traçado, foi portanto, durante a administração Prado Júnior que a idéia de um sistema metroviário para o Rio de Janeiro foi formalmente apresentada.

A idéia da implantação de um metrô foi retomada em 1947 pela Light e, mais uma vez, ela não foi aceita. A então denominada Companhia Carris, Luz e Força do Rio de Janeiro Ltda Light propôs para a cidade do Rio de Janeiro, nessa época com cerca de 2.000.000 habitantes, uma linha que se estendia desde Copacabana na Zona Sul até a Tijuca na Zona Norte, passando pelas Avenidas Rio Branco e Presidente Vargas e outra linha que, partindo do Centro atingiria Ramos também na Zona Norte. As duas linhas atravessavam áreas de alta densidade demográfica, totalizando 50 km de construção subterrânea, ambas com previsão de expansões. Esta proposta da Companhia Light vinha acompanhada de um estudo de viabilidade financeira, que concluía que, com um aumento de 15\% nas passagens de bonde, haveria capital suficiente para o empreendimento. Mais uma vez a Light tentou unificar os sistemas sob sua gestão - bondes, ônibus e metrô - de forma que a via férrea subterrânea se constituísse em espinha dorsal do sistema.

\footnotetext{
${ }^{4}$ Informações obtidas a partir de COMPANHIA DO METROPOLITANO DO RIO DE JANEIRO. Livro

Histórico do Metrô. Rio de Janeiro [s.n.], 1977.
} 
Durante o período de cerca de 20 anos entre as duas importantes iniciativas da Light, surgiram estudos feitos por profissionais, ligados ou não à administração pública, que, numa postura acadêmico-progressista, apresentaram diagnósticos sobre a situação dos transportes no Distrito Federal. Os estudos dos engenheiros Raimundo Pereira da Silva $(1936)^{5}$ e Francisco Ebling (1943) ${ }^{6}$, por exemplo, não se limitavam apenas ao atendimento da demanda, mas se preocupavam, principalmente, com o crescimento e a estruturação do espaço urbano, propondo eixos estruturais de desenvolvimento - que incluíam a rede de subúrbios e o metrô. Pereira da Silva propunha extensões da rede sobre trilhos para muito além da área urbanizada à época, atendendo as zonas suburbanas e rurais, visando o desenvolvimento futuro de áreas ainda pouco habitadas, como Santa Cruz. Os trechos subterrâneos deveriam desafogar o Centro na direção Sul, até Copacabana. Ebling, por sua vez, considerava a Zona Sul de prioridade secundária, propondo o metrô para o Centro e a melhoria e expansão ferroviária Norte e Oeste, coincidindo com a própria rede suburbana da EFCB, justificando essa opção pela presença de um maior número de usuários nessas direções. Os autores desses estudos utilizaram o Clube de Engenharia, importante associação de classe no Rio de Janeiro, para a divulgação de suas idéias.

Em 1937, ainda nesse período, foi apresentada pela companhia inglesa Railplane System of Transport, através da Companhia Brasileira de Transportes Planaéreos ${ }^{7}$, uma proposta que novamente materializou o interesse do capital privado, ao sugerir um sistema de metrô elevado

\footnotetext{
${ }^{5}$ O Estabelecimento da Estrada de Ferro Metropolitana no Distrito Federal, conferência do engenheiro Raimundo Pereira da Silva, apresentada no Clube de Engenharia em 1936, segundo o Livro Histórico do Metrô, já citado.

${ }^{6}$ Metropolitano - Rede Subterrânea de Trens Elétricos da Cidade do Rio de Janeiro, conferência do engenheiro Francisco Ebling, apresentada no Clube de Engenharia em 1943, segundo o Livro Histórico do Metrô, já citado.

${ }^{7}$ Studies for the Aplication of the Railplane System of Transport in Rio de Janeiro, conferência apresentada pela Companhia Brasileira de Transportes Planaéreos em 1937, segundo o Livro Histórico do Metrô, já citado.
} 
em estrutura metálica, com unidades para 100 passageiros que atingiria velocidades de 200 km/hora (velocidades inexistentes à época), com características semelhantes ao utilizado na Inglaterra, reunindo pareceres de técnicos internacionais que justificavam a proposta. Mais abrangente do que a segunda proposta da Light, de 1947, a Railplane retomou grande parte das recomendações gerais do Plano Agache e apresentou estudos técnicos contendo modificações nos leitos das estradas de ferro existentes, para comportar o sistema de metrô. Baseou-se em estudo financeiro detalhado. Essa proposta não encontrou respaldo na administração Henrique Dodsworth, durante o Estado Novo, cujas preocupações se concentravam nos problemas imediatos de circulação da cidade, privilegiando a expansão do sistema viário com a abertura de grandes avenidas, ainda numa visão Hausmaniana da cidade.

O Plano Piloto do Rio de Janeiro, elaborado pela Comissão do Plano da Cidade no período de 1938 a 1948, previa a construção dos principais túneis de ligação viária Zona Norte - Zona Sul que vieram a ser realizados na década de 1960, tendo sido amplamente criticado pelos técnicos especialistas em transportes à época, devido à falta de importância dada ao transporte rápido de massa sobre trilhos, como pode ser atestado pela conferência do Engenheiro José Côrtes Sigaud $^{8}$ no Clube de Engenharia, em 1948. Sigaud recomendava uma solução com galerias subterrâneas no centro e estruturas elevadas em direção aos bairros, afirmando que as soluções elevadas eram mais baratas e, desta forma, poderiam ser construídas linhas mais extensas, atendendo a um número maior de usuários.

Nesse mesmo ano, a SGTE - Societé Génèrale de Traction et Exploitation apresentou um estudo que respondia aos interesses da administração do Distrito Federal quanto aos

\footnotetext{
${ }^{8}$ O Plano Diretor de Melhoramentos do Rio de Janeiro e seu Problema de Tráfego, conferência do engenheiro José Côrtes Sigaud, apresentada no Clube de Engenharia em 1948, segundo o Livro Histórico do Metrô, já citado.
} 
transportes sobre trilhos, uma vez que a Prefeitura chegou a criar a CEPM - Comissão Executiva do Projeto Metropolitano para promover a elaboração de projeto baseado nesse estudo. A SGTE propôs três linhas-tronco partindo do Centro, no sentido Norte até Madureira, com 20 km, no sentido Oeste até a Tijuca, com 9 km e no sentido Sul até o Lido, com $11 \mathrm{~km}$, num total de $40 \mathrm{~km}$.

Paralelamente, o engenheiro Ebling continuou a defender suas idéias de que o metrô já estaria praticamente pronto com a capacitação das estradas de ferro existentes, através da implantação da tecnologia metroviária nas linhas de superfície, invocando a abrangência do projeto, tanto espacialmente quanto com relação ao número de usuários. Suas idéias foram amplamente discutidas na Câmara de Vereadores, no executivo e na imprensa, bem como as idéias do grupo francês.

Não obstante todas as idéias dos engenheiros brasileiros, foi a proposta francesa que o Prefeito João Carlos Vidal enviou em 1952 à Câmara na forma de Projeto de Lei, autorizando a elaboração de Projeto Executivo e o início da construção, podendo este ser considerado o ponto de partida dos esforços institucionais, inclusive com a de criação de entidade executora - Comissão Executiva do Metropolitano do Rio de Janeiro ${ }^{9}$. As discussões prosseguiram, sempre confrontando as duas idéias, Ebling (ferrovia - projeto mais abrangente) versus Proposta Francesa ${ }^{10}$ (SGTE e Comissão do Metropolitano - proposta de metrô tradicional). Segundo Maria Lais Pereira da Silva ${ }^{11}$, essa polarização de idéias não retratava apenas

\footnotetext{
${ }^{9}$ Segundo REIS, J. de O. O Rio de Janeiro e seus Prefeitos: Evolução Urbanística da Cidade. Prefeitura da Cidade do Rio de Janeiro, Rio de Janeiro, 1977. 167 p., página 127.

${ }^{10}$ Maria Lais Pereira da Silva chama a atenção para a presença francesa no Rio de Janeiro para estudar o sistema ferroviário em operação e que se aproximaram de muitos engenheiros ferroviários brasileiros, anteriormente citada, página 87.

${ }^{11}$ Maria Lais Pereira da Silva, anteriormente citada, página 88.
} 
diferenças técnicas e de abrangência social e espacial, mas apresentava um viés político importante quando se observa que o apoio à solução ferroviária - grandes melhorias nos trens de subúrbio - daria maiores poderes ao governo federal, proprietária e gestora do sistema existente, enquanto que um sistema metropolitano municipal fortaleceria os grupos ligados à esfera de poder local, configurando uma disputa entre o poder federal e a oposição local. Porém nada chegou a ser implantado, apesar dos extensos debates.

Embora o projeto francês da SGTE estivesse formalmente aprovado, observa-se durante os anos 1950 outro afluxo de idéias sobre a necessidade de um sistema de metrô, sendo que na maioria das vezes os profissionais se manifestaram através do Clube de Engenharia. Os estudos de Fernando Lavrador ${ }^{12}$ (1951), Ferreira Sampaio ${ }^{13}$ (1953) e Gadret e Filgueiras ${ }^{14}$ (1957) apresentavam uma preocupação mais específica com o sistema de metrô tradicional, elevado ou subterrâneo, e não necessariamente com a situação ferroviária ou dos transportes em geral. Suas propostas estavam inseridas nas áreas mais centrais e mais densamente urbanizadas.

Pode-se inferir que essa nova coincidência temporal de propostas, com ênfase nos trilhos, tenha sido uma reação à política desenvolvimentista do Governo Juscelino Kubitschek, que

\footnotetext{
${ }^{12}$ Observações sobre Transporte Subterrâneo no Rio de Janeiro, proposta do engenheiro Fernando Lavrador, feita em 1951, através da Revista do Clube de Engenharia. Tratava-se de uma rede subterrânea, com cerca de 90 km, densa, à semelhança do Metrô parisiense, chegando até Ipanema, Gávea, Laranjeiras, Caju e Engenho Novo, segundo o Livro Histórico do Metrô.

${ }^{13}$ O engenheiro Geraldo Ferreira Sampaio apresentou à Secretaria de Viação e Obras da Prefeitura em 1953 um memorial sobre transporte coletivo para a Zona Sul em linha elevada pelas encostas e vales. Na Zona Norte, o traçado passava pela avenida Diagonal, Canal do Mangue e Canal do Maracanã, chegando até a Tijuca em linha elevada.

${ }^{14}$ A proposta do engenheiro Hilton de Jesus Gadret e do advogado Roberto Souza Pinto Filgueiras, ambos assessores do prefeito Negrão de Lima, elaborada em 1957, mas somente publicada em 1960, praticamente abolia o sistema suburbano na direção Oeste e o substituía por uma linha subterrânea sob o atual leito da ferrovia, da Lapa até Deodoro, dando lugar na superfície a uma avenida com três pistas em cada sentido. Na Zona Sul, a linha partia do Largo de São Francisco pelas avenidas projetadas Norte-Sul e Radial Sul até Humaitá e em seguida para Copacabana, sendo que para o futuro estavam previstas extensões para o Leme e/ou Ipanema. Na Tijuca, a linha seria elevada. Informações obtidas no Livro Histórico do Metrô.
} 
favorecia amplamente a indústria rodoviária em detrimento da ferrovia. É importante notar que as ferrovias praticamente receberam seus últimos investimentos de capital significativos em meados da década de 1930. Nas áreas urbanas, assistiu-se à rápida substituição dos trens e bondes pelos ônibus para o transporte da população trabalhadora, iniciando-se uma utilização mais intensiva das vias já existentes bem como foram feitos investimentos significativos no sistema viário em geral. Novas rodovias foram construídas - Presidente Dutra e Washington Luís. Os autores desses estudos, no entanto, não desejavam sua identificação direta com o sistema ferroviário, estigmatizado como antiquado, mas sim com uma inovação tecnológica representada pelo metrô.

É interessante observar que Gadret e Filgueiras eram assessores do Prefeito em exercício, Negrão de Lima (1956 a 1958), que, mesmo atuando em forte sintonia política com o Presidente Kubitschek iria, dez anos mais tarde, então como governador do Estado da Guanabara, aprovar definitivamente a construção do Metrô hoje em operação. Negrão de Lima, como veremos mais adiante, trabalhou para o desencadeamento de ações substantivas no que se refere ao Metrô, mas cabe lembrar que sua administração como prefeito se desenrolou numa época crítica para o Rio de Janeiro: nos anos que antecedem a mudança da capital para Brasília, momento em que todo o esforço federal esteve concentrado na construção da nova Capital. A cidade, sem recursos municipais e nem estaduais, à mercê do Governo Federal, ficou à espera da nova organização política e da constituição do novo estado e quase nada foi realizado nesse período de mudança.

No âmbito das idéias, é no final da década de 1950 que pôde ser observado um esforço da administração pública em resolver os gargalos na prestação de serviços pelo sistema de bondes e ao mesmo tempo, em reforçar a necessidade de um transporte do tipo metrô. As 
comissões $^{15}$ e os grupos de estudo se sucederam na formulação de idéias, com maior ou menor apoio dos agentes decisórios. Discutiu-se o metrô como iniciativa do poder público e de caráter corretivo, ou seja, a ser construído no corredor de tráfego mais saturado para solucionar pressões de tráfego e para resolver o problema da concessão dos serviços de bonde, prestes a expirar. Não tinha por objetivo a implantação de um elemento organizador do espaço urbano e indutor de novas localizações de atividades.

A Ilustração 14 - Principais Estudos sobre o Metrô na cidade do Rio de Janeiro apresenta a cronologia dos principais estudos, situando-os nos períodos das diversas administrações e fases de soberania política da cidade do Rio de Janeiro, ou seja, enquanto Distrito Federal, Estado da Guanabara e capital do novo Estado do Rio de Janeiro.

\footnotetext{
${ }^{15}$ Maria Lais Pereira da Silva cita pelo menos duas comissões criadas com o objetivo de conceber uma solução para o problema dos bondes: a Comissão de Estudo e Planejamento do Serviço de Autocarros Elétricos CEPAE e a Comissão de Estudos do Serviço de Bondes, ambas funcionando no Instituto de Engenharia.
} 


\begin{tabular}{|c|c|c|c|c|c|}
\hline ANO & ESTUDO / PROPOSTA & $\begin{array}{l}\text { TIPO DE EXTENSÃO } \\
\text { ABRANGÊNCIA }\end{array}$ & $\begin{array}{l}\text { PRESENÇA } \\
\text { ESTRANGEIRA }\end{array}$ & PATROCÍNIO & FATOS E PERÍODOS POLÍTICOS \\
\hline & & & & & Distrito Federal \\
\hline 1911/18 & $\begin{array}{l}\text { Eng. e Conselheiro Álvaro Joaquim de } \\
\text { Oliveira }\end{array}$ & $\begin{array}{l}\text { Trem subterrâneo Centro- } \\
\text { Cascadura }\end{array}$ & - & $\begin{array}{l}\text { Proposta isolada e posteriormente feita através do } \\
\text { Clube de Engenharia }\end{array}$ & $\begin{array}{l}\text { Prefeitos General Bento Ribeiro, Rivadávia Corrêa, Antonio Augusto de } \\
\text { Azevedo Sodré e Amaro Cavalcanti }\end{array}$ \\
\hline 1928/30 & Plano Agache & Metrô Clássico - Centro & - & Prefeitura do Distrito Federal & Prefeito Prado Júnior \\
\hline 1929 & Memorial da Light - eng. Norman Wilson & Metrô Clássico - Centro & Inglês & $\begin{array}{l}\text { Proposta Isolada propondo parceria com a } \\
\text { Prefeitura do Distrito Federal }\end{array}$ & Prefeito Prado Júnior \\
\hline 1936 & Estudo do eng ${ }^{\circ}$ Raimundo Pereira da Silva & $\begin{array}{l}\text { Ferrovia e Metrô Clássico } \\
\text { Regional, Subúrbios e Centro }\end{array}$ & - & Estudo Isolado & Prefeitos Pedro Ernesto Batista e Olímpio de Melo \\
\hline 1937 & \begin{tabular}{|l|} 
Estudo da Railplane System of Transport I \\
Cia. Brasileira de Transportes Planaéreos
\end{tabular} & $\begin{array}{l}\text { Ferrovia e Metrô Clássico } \\
\text { Regional, Subúrbios e Centro } \\
\end{array}$ & Inglês & Estudo Isolado & Prefeitos Olímpio de Melo e Henrique Dodsworth \\
\hline 1943 & Estudo do eng ${ }^{\circ}$ Francisco Ebling & $\begin{array}{l}\text { Ferrovia e Metrô Clássico, } \\
\text { Subúrbios e Centro }\end{array}$ & - & Estudo Isolado & Prefeito Henrique Dodsworth \\
\hline 1947 & Proposta da Companhia Light & Metrô Clássico - Centro & Inglês & Proposta Isolada propondo construção e operação & Prefeitos Hildebrando de Góes e Gal. Mendes de Morais \\
\hline 1948 & Estudo do eng ${ }^{\circ}$ José Côrtes Sigaud & Metrô Clássico - Centro & - & Prefeitura do Distrito Federal & Prefeito Gal. Mendes de Morais \\
\hline $1948 / 51$ & $\begin{array}{l}\text { SGTE - Soc. Générale Traction et } \\
\text { Exploitation/CEPM }\end{array}$ & Metrô Clássico - Centro & Francês & Prefeitura do Distrito Federal & Prefeitos Gal. Mendes de Morais e João Carlos Vital \\
\hline 1951 & Estudo do eng ${ }^{\circ}$ Fernando Lavrador & Metrô Clássico - Centro & - & Estudo Isolado & Prefeitos Gal. Mendes de Morais e João Carlos Vital \\
\hline 1953 & Estudo do eng ${ }^{\circ}$ Geraldo Ferreira Sampaio & Metrô Clássico - Centro & - & $\begin{array}{l}\text { Prefeitura do Distrito Federal - Secretaria de } \\
\text { Viação e Obras }\end{array}$ & Prefeito Dulcídio Cardoso \\
\hline $1957 / 60$ & $\begin{array}{l}\text { Estudo dos eng. Hilton Jesus Gadret e } \\
\text { adv. Roberto Souza Pinto Filgueiras }\end{array}$ & Metrô Clássico - Centro & - & Prefeitura do Distrito Federal & Prefeitos Negrão de Lima e Sá Freire Alvim \\
\hline 1959 & Comissão - eng ${ }^{\circ}$ Mauro R. Vielas & & - & $\begin{array}{l}\text { Prefeitura do Distrito Federal - Secretaria de } \\
\text { Viação e Obras }\end{array}$ & Prefeito Sá Freire Alvim \\
\hline 1960 & & & & & Criação do Estado da Guanabara \\
\hline \multirow[t]{6}{*}{1962} & Simpósio Clube de Engenharia & & - & & Governador Carlos Lacerda \\
\hline & $\begin{array}{l}\text { Estudo eng. Jorge Ernesto de Miranda } \\
\text { Schnoor }\end{array}$ & $\begin{array}{l}\text { Ferrovia e Metrô Clássico, } \\
\text { Subúrbios e Centro }\end{array}$ & - & Estudo Isolado & Governador Carlos Lacerda \\
\hline & Estudo eng. Antonio Arlindo Laviola & $\begin{array}{l}\text { Metrô Clássico - Centro e } \\
\text { melhorias na ferrovia }\end{array}$ & - & Estudo Isolado & Governador Carlos Lacerda \\
\hline & Estudo eng. Luis Antonio de Souza Leão & Metrô Elevado - Centro & - & Estudo Isolado & Governador Carlos Lacerda \\
\hline & Estudo eng. Murilo Nunes Azevedo & $\begin{array}{l}\text { Ferrovia e Metrô Clássico, } \\
\text { Subúrbios e Centro }\end{array}$ & - & Estudo Isolado & Governador Carlos Lacerda \\
\hline & Estudo eng. Luiz Onofre Pinheiro Guedes & Monorail - Alineg & Alemão & Estudo Isolado & Governador Carlos Lacerda \\
\hline \multirow[t]{2}{*}{$1963 / 66$} & Estudo eng $^{\circ}$ Fernando Lavrador & $\begin{array}{l}\text { Metrô Clássico - Centro e } \\
\text { expansão e melhorias na } \\
\text { ferrovia }\end{array}$ & - & & Governadores Carlos Lacerda e Negrão de Lima \\
\hline & & & & & Golpe de Estado 1964 \\
\hline 1965 & Plano Doxiadis & Metrô Clássico - Centro & - & Estado Guanabara & Governador Carlos Lacerda \\
\hline 1966 & CEPE -2 & Metrô Clássico - Centro & - & Estado Guanabara & Governo Negrão de Lima \\
\hline 1967 & Companhia Pandora & Metrô Elevado & - & \begin{tabular}{|l|l} 
Estudo Isolado \\
\end{tabular} & Governo Negrão de Lima \\
\hline 1968 & $\begin{array}{l}\text { Estudo de Viabilidade do Metrô - RJ / CCN } \\
\text { - Hochtief - Deconsult Resultou na } \\
\text { Aprovação e Implantação do Sist. }\end{array}$ & Metrô Clássico & $\begin{array}{l}\text { Estudo Alemão Propostas } \\
\text { Francesas, Alemãs e } \\
\text { Americanas }\end{array}$ & Estado Guanabara & Governo Negrão de Lima \\
\hline 1969 & Estudo da Missão Japonesa & Monorail - Subúrbios & Japonês & $\begin{array}{l}\text { Governo Federal - Ministério da Indústria e } \\
\text { Comércio }\end{array}$ & Governo Chagas Freitas \\
\hline 1973 & Estudo Cia Japonesa & Monorail - Subúrbios & Japonês & Estado Guanabara - Sec. Planejamento & Governo Chagas Freitas \\
\hline 1975 & & & & & Fusão dos Estados - Criação Estado do RJ e Município RJ \\
\hline 1975 & & & & & Gov. Faria Lima e Pref. Marcos Tamoio \\
\hline 1979 & & & & & Governador Chagas Freitas e Prefeito Israel Klabin \\
\hline
\end{tabular}

Ilustração 14 - Principais Estudos sobre o Metrô na cidade do Rio de Janeiro 
Observa-se que no período de 10 anos que antecedeu o “Estudo de Viabilidade - 1968” estudo base para a implantação do Metrô hoje em operação -, as comissões e grupos de estudo, constituídos com a finalidade de dar andamento ao Metrô-RJ, tiveram denominações diferentes, mas guardavam a presença de algumas pessoas chave que permaneceram em todo o processo de consolidação da idéia da implantação do sistema. Através da ilustração 14, é possível distinguir alguns nomes que estiveram presentes ao longo do tempo, o que garantiu uma certa continuidade na maneira de se pensar o Metrô.

Já no início dos anos 1960, o Engenheiro Fernando Lavrador ampliou sua proposta de 1951, acrescentando melhorias do sistema ferroviário existente e ampliando o âmbito do projeto com a extensão das ligações férreas dos subúrbios (Madureira) até a Zona Sul (Leblon) chegando até a Baixada de Jacarepaguá.

Foi muito reveladora a realização, em 1962, pelo Clube de Engenharia ${ }^{16}$, de um simpósio reunindo propostas para a implantação do Metrô, durante a administração Carlos Lacerda, o primeiro governo do recém-criado Estado da Guanabara, administração que nada fez na direção de sua realização, investindo unicamente em obras viárias ${ }^{17}$.

O Clube de Engenharia convidou diversos profissionais, numa tentativa de promover um consenso sobre o sistema de transporte rápido de massa adequado à cidade do Rio de Janeiro.

\footnotetext{
${ }^{16}$ Simpósio do Clube de Engenharia, realizado em 1962, por iniciativa do engenheiro Hélio de Almeida, convocando engenheiros que quisessem participar da definição da posição do Clube de Engenharia sobre a questão do Metrô. Informações obtidas através do Livro Histórico do Metrô.

${ }^{17}$ No governo Carlos Lacerda foi criada a comissão mista Estado e Governo Federal, instalada no Ministério de Viação e Obras Públicas, para viabilizar o Metrô. O próprio governador chegou a viajar para a França com o intuito de conseguir financiamento para o Metrô do Rio de Janeiro, mas, objetivamente, não foi na sua gestão, de franca oposição ao Governo Federal, que o processo de implantação teve início.
} 
Foram realizadas cinco conferências principais ${ }^{18}$, que apresentaram propostas de engenheiros que iriam, mais tarde, participar de novas comissões e grupos de estudo e que trabalharam efetivamente para a concretização da idéia, muitos dos quais participando do importante Grupo de Trabalho de 1966, criado pelo Governador Negrão de Lima.

A maioria dos trabalhos apresentados recomendava linhas subterrâneas e/ou em nível, sem indicar tecnologia específica, à exceção do estudo do Engenheiro Luiz Onofre Pinheiro Guedes, que recomendava o sistema de monotrilho alemão do tipo Alweg, segundo ele, mais barato e mais adaptável à topografia e às condições urbanísticas locais. A proposta do Engenheiro Antonio Arlindo Laviola diferia da maioria dos estudos, pois acentuava a importância da melhoria e expansão do sistema ferroviário existente, utilizando os trens da EFCB e propondo apenas uma linha subterrânea, circular no centro, mantendo a mesma bitola da ferrovia.

O engenheiro Luis Antonio de Souza Leão propôs um sistema junto aos morros, com trechos elevados e subterrâneos, fugindo dos itinerários de maior demanda, de modo a facilitar a construção. O engenheiro Murilo Nunes de Azevedo apresentou proposta para a modernização e adaptação do sistema suburbano, separando carga e passageiro e a construção de duas linhas subterrâneas, para a Zona Sul, passando pela Glória até o Lido e para a Zona Norte, até a Tijuca, tangenciando a ferrovia. O engenheiro Jorge Ernesto de Miranda Schnoor, um dos conferencistas do simpósio, esteve presente no processo de idealização do Metrô pelo menos desde meados da década de 1950, ao participar de quase todas as comissões que se

\footnotetext{
${ }^{18}$ Outras contribuições na forma de artigos e monografias foram feitas por: José de Oliveira Reis, Hermínio de Andrade e Silva, Tobias Visconti, Jerônimo Cavalcanti, Francisco Ebling, Jerônimo Monteiro Filho, Antonio Onofre Morais Lacerda, Ernani Mota Resende, Geraldo Sampaio, Hilton Jesus Gadret e Carlos Catapan, dentre outros, segundo o Livro Histórico do Metrô.
} 
formaram até a aprovação final do empreendimento. Seu estudo apresentava linhas que, partindo do Centro (Largo da Carioca) atingiriam Botafogo, Copacabana e Ipanema, na Zona Sul; Niterói no sentido Leste, atravessando a Baía; Tijuca no sentido Oeste, continuando nesse sentido até Jacarepaguá. Adicionalmente, deveria acompanhar a EFCB até o subúrbio de Deodoro e também a antiga Ferrovia Rio d’Ouro até Pavuna, num traçado muito semelhante, porém mais abrangente, que o aprovado em 1968.

O parecer final e consensual do simpósio do Clube de Engenharia recomendou a implantação de um sistema de Metrô, como providência absolutamente necessária, sugerindo um sistema clássico, subterrâneo no trecho que partia de Copacabana chegando até as estações da rede ferroviária passando pelo Centro, no corredor entre o mar e a montanha. Numa segunda etapa, indicava a construção da linha subterrânea Glória - D. Pedro II, seguindo em elevado até o Maracanã. Embora reforçasse também a importância de se investir no sistema ferroviário, pode-se afirmar que o parecer final do Clube de Engenharia representou uma ruptura com relação ao conceito de Metrô associado à rede ferroviária tradicional. O sistema metroviário, com raras exceções, passou a ser tratado de forma totalmente isolada do conjunto dos sistemas de transportes sobre trilhos.

O Plano Doxiadis (1965), Guanabara - a Plan for Urban Development, primeiro estudo no Brasil a usar a técnica americana do modelo a quatro etapas, apresentou uma proposta de vias expressas distribuídas regularmente por todo o território, característica dos planos Doxiadis para outras cidades, e indicava também a necessidade de um metrô. Defendia a idéia, já apresentada em 1957 pelos engenheiros Gadret e Filgueiras, de uma linha subterrânea associada a uma via rodoviária dupla, em nível, ao longo de toda rede ferroviária suburbana, 
de Madureira até Santa Cruz, como parte de um plano que, entretanto, em linhas gerais, favorecia claramente os deslocamentos através do modo rodoviário ${ }^{19}$.

A partir da segunda metade do século XX, a iniciativa privada não mais se apresentou como sócia ou parceira do poder público na implantação do Metrô, mas como possível produtora das diversas etapas da implantação do mesmo, cuja responsabilidade seria pública, incluindo a totalidade do aporte de recursos financeiros. Ao final da década de 1960 e início da década de 1970, alguns grupos internacionais ofereceram à administração pública estudos e/ou projetos de redes de metrô para o Rio de Janeiro que utilizariam tecnologias de seu domínio e interesse. É o caso das empresas que responderam à licitação pública internacional para a contratação do Estudo de Viabilidade, que se constituiu nos fundamentos para o sistema de Metrô hoje em operação, bem como os japoneses que em 1969, por solicitação do Governo Federal, do Ministério da Indústria e Comércio, recomendou uma linha de monotrilho de 25 km, ligando a Barra da Tijuca ao Aeroporto do Galeão, antevendo a Exposição Internacional de $1972^{20}$. Em 1973, novamente os japoneses tentaram participar do processo, através da International Engineering Consultants Association, apresentando estudo para o trecho Estácio - Pavuna, em monotrilho, para substituir o sistema alemão aprovado em 1968. Continha também sugestões para uma segunda linha, ligando o Leblon à Barra da Tijuca. Este estudo foi encomendado pela Secretaria de Planejamento e Coordenação Geral do Estado da Guanabara.

\footnotetext{
${ }^{19}$ Pelo Plano Doxiadis seriam construídos cerca de $400 \mathrm{~km}$ de vias expressas e $550 \mathrm{~km}$ de vias principais, para o transporte rodoviário, enquanto que a rede de Metrô teria uma extensão aproximada de $80 \mathrm{~km}$, associada ao viário principal.

${ }^{20}$ A já constituída Companhia do Metrô foi ouvida e apresentou parecer desfavorável, afirmando que o projeto não resolvia o transporte de massa e tumultuaria o transporte de superfície, desperdiçando recursos. Como a Exposição de 1972 foi cancelada, o assunto foi arquivado, segundo informações do Livro Histórico do Metrô.
} 
A Ilustração 15 - Principais Traçados Propostos para o Metrô do Rio de Janeiro, reúne os traçados definidos pelos principais estudos, a partir da segunda proposta da Companhia Light de 1947. Estão representados:

- a proposta da Companhia Light de 1947;

- a proposta da CEPM, elaborada pela SGTE em 1948;

- o estudo do eng ${ }^{0}$ Laviola para o simpósio do Clube de Engenharia, de 1962;

- o estudo do eng ${ }^{0}$ Azevedo, para o mesmo simpósio em 1962;

- o estudo do eng ${ }^{0}$ Souza Leão, para o mesmo simpósio em 1962;

- o traçado consensual recomendado pelo Clube de Engenharia;

- o estudo do eng ${ }^{0}$ Schnoor, apresentado em 1962 e divulgado em 1968;

- o estudo do consórcio vencedor da concorrência internacional apresentado em $1968^{21}$.

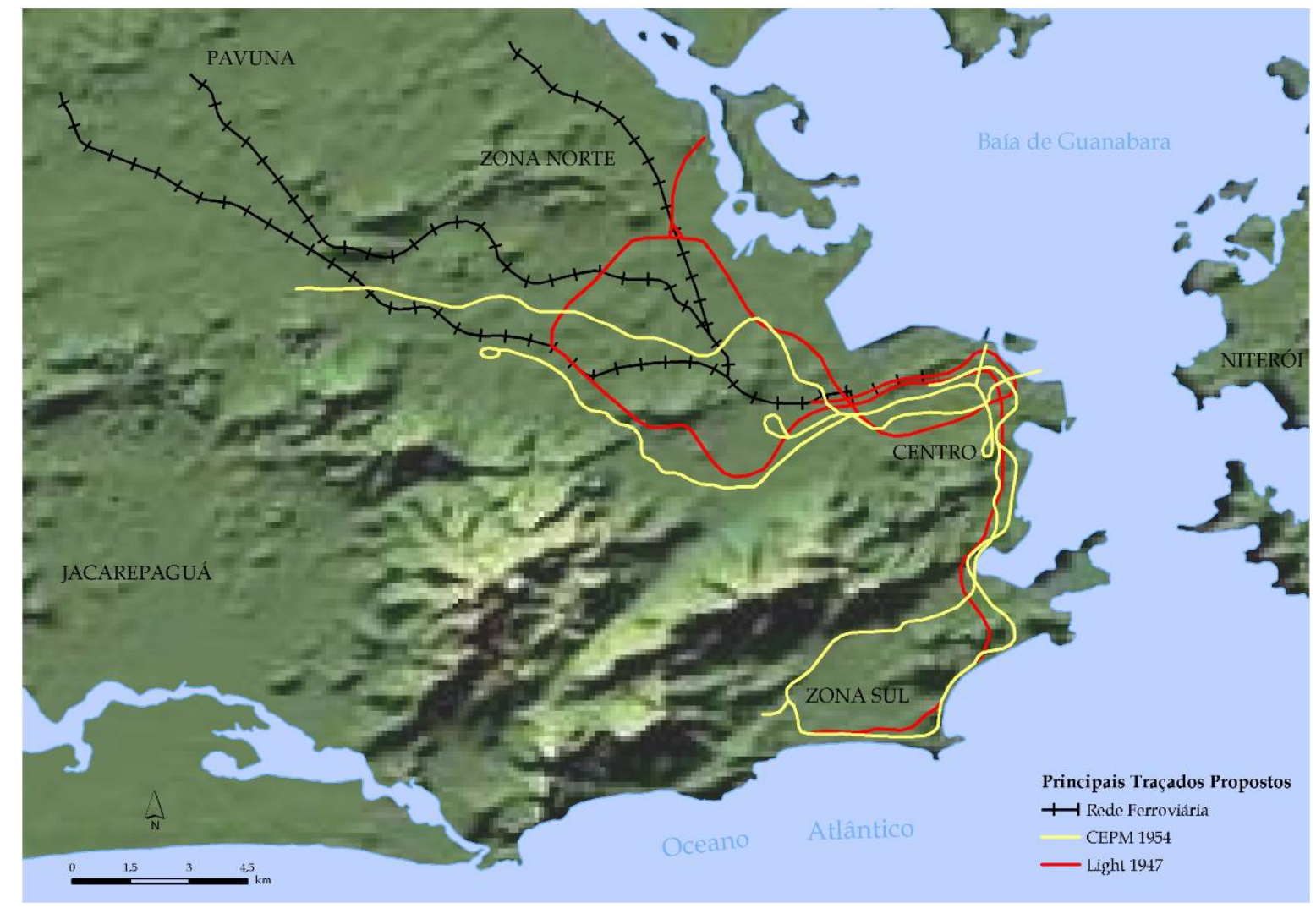

\footnotetext{
${ }^{21}$ A localização dessa proposta é apresentada para efeito de comparação com os estudos anteriores, sendo descrito com mais detalhe, posteriormente, neste mesmo capítulo.
} 

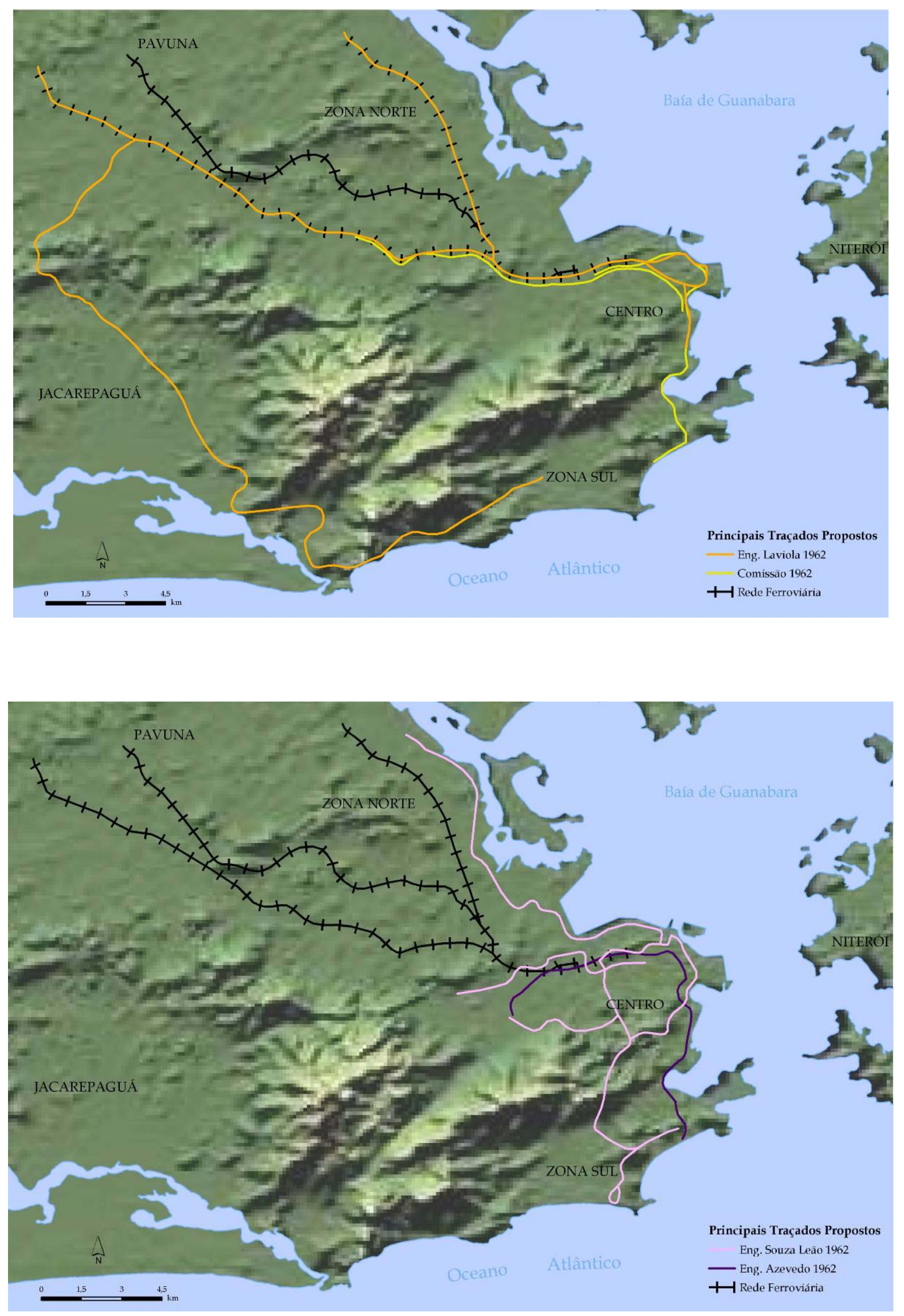


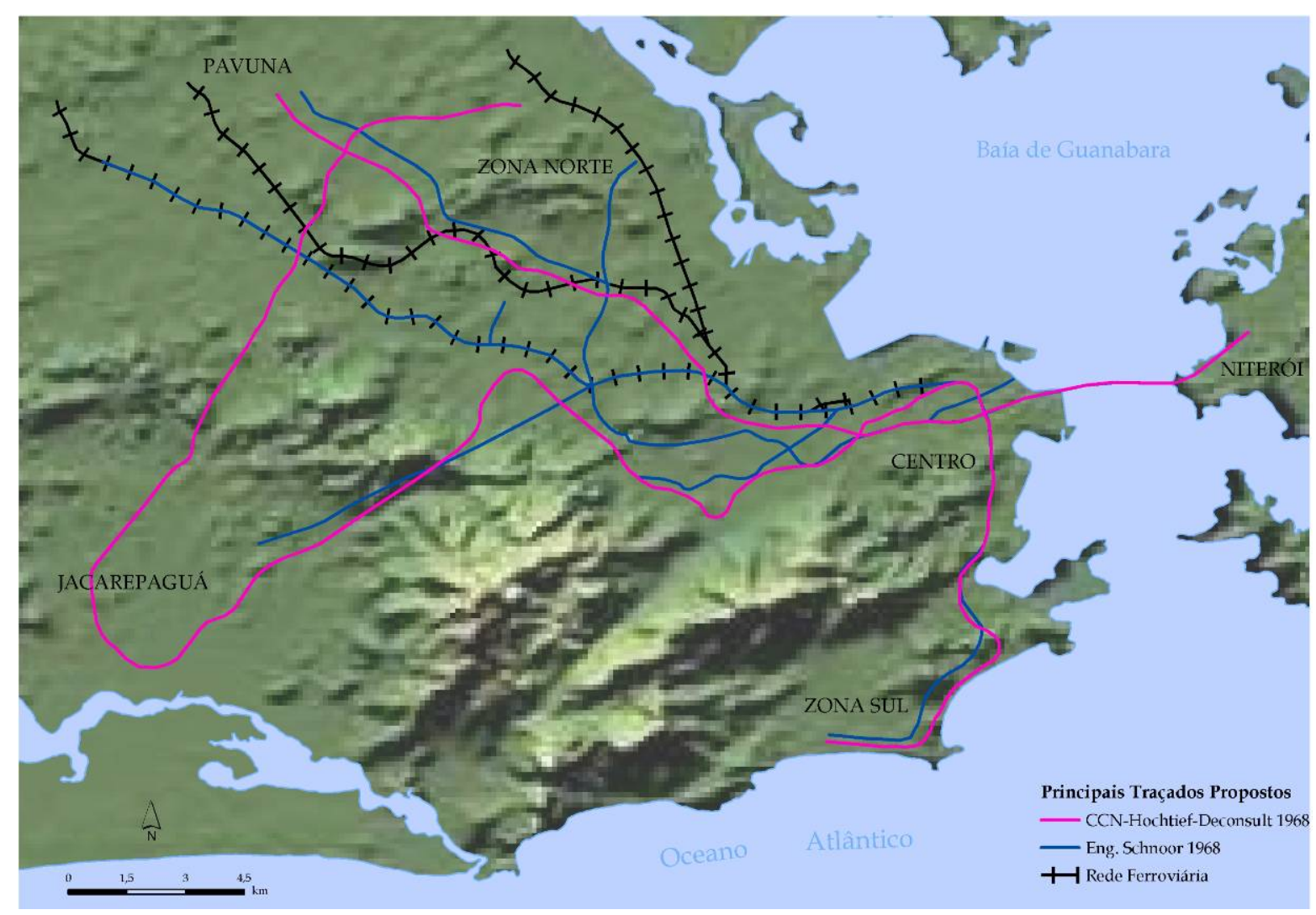

Referência: COMPANHIA DO METROPOLITANO DO RIO DE JANEIRO. Livro Histórico do Metrô. Rio de Janeiro [s.n.], 1977.

\section{Ilustração 15 - Principais Traçados Propostos para o Metrô do Rio de Janeiro}

A Ilustração 15 facilita a observação de que a grande maioria dos estudos considera a ligação Zona Norte - Zona Sul, passando pelo Centro e através do estreito corredor de maior tráfego, apertado entre o mar e a montanha, o trecho a ser construído em prioridade. Variações quanto à sua extensão no sentido da Zona Sul indo até o Botafogo, Copacabana ou chegando até o Leblon, demonstram o interesse em atender mais, ou menos, a população de maior poder aquisitivo, considerando, entretanto, prioritário o descongestionamento do setor sul da cidade, pelo menos até o bairro do Botafogo. A área que vai do Centro até a Zona Norte, de maior extensão territorial e com menores restrições ambientais, permitia uma certa variação no traçado, mas quase todos os estudos são unânimes em passar pela principal estação de subúrbios, a Estação Central, e dela dirigir-se para o bairro da Tijuca. 
As maiores diferenças se revelam na intenção de servir, ou não, a região dos subúrbios e até onde e como servi-los. Uma grande parte dos estudos acompanhava as linhas da rede ferroviária, através de uma ou mais penetrações no interior da região suburbana, numa filosofia de melhoria da ferrovia ou mesmo na implantação de um novo sistema, utilizando o leito das mesmas. Poucos, na verdade apenas três estudos, consideravam as novas áreas de urbanização da Baixada de Jacarepaguá na Zona Oeste.

O traçado aprovado através do Estudo de Viabilidade do Consórcio CCN - Hochtief Deconsult de 1968, indicava a construção de duas linhas, uma com 37 km, de Ipanema até a Baixada de Jacarepaguá passando pelo Centro e outra com 30 km de Pavuna a Niterói, também passando pelo Centro, com duas estações de transferência - Estácio e Largo da Carioca. O trecho prioritário seria de Ipanema até o bairro da Tijuca.

Finalmente, o traçado que veio a ser efetivamente aprovado e implantado difere daquele definido através do Estudo de Viabilidade de 1968, pois a Linha 1 (prioritária) deixou de alcançar Copacabana, limitando-se, no sentido da Zona Sul, ao bairro do Botafogo. A Linha 2, por sua vez, seria construída concomitantemente ao trecho inicialmente prioritário, indo do Estácio até a Pavuna, sendo que no trecho Maria da Graça até a Pavuna seria construído em superfície, com tecnologia de pré-metrô. O trecho que deveria alcançar Niterói ficaria postergado.

\subsection{Iniciativas de Caráter Institucional}

A Ilustração 16 - Ocorrência dos Estudos/Propostas de Transporte Metroviário apresenta as iniciativas de caráter institucional que ocorreram no intervalo de 20 anos, 1949-1968, período em que a idéia de se implantar um sistema de metrô se fortaleceu, através de comissões e grupos de 


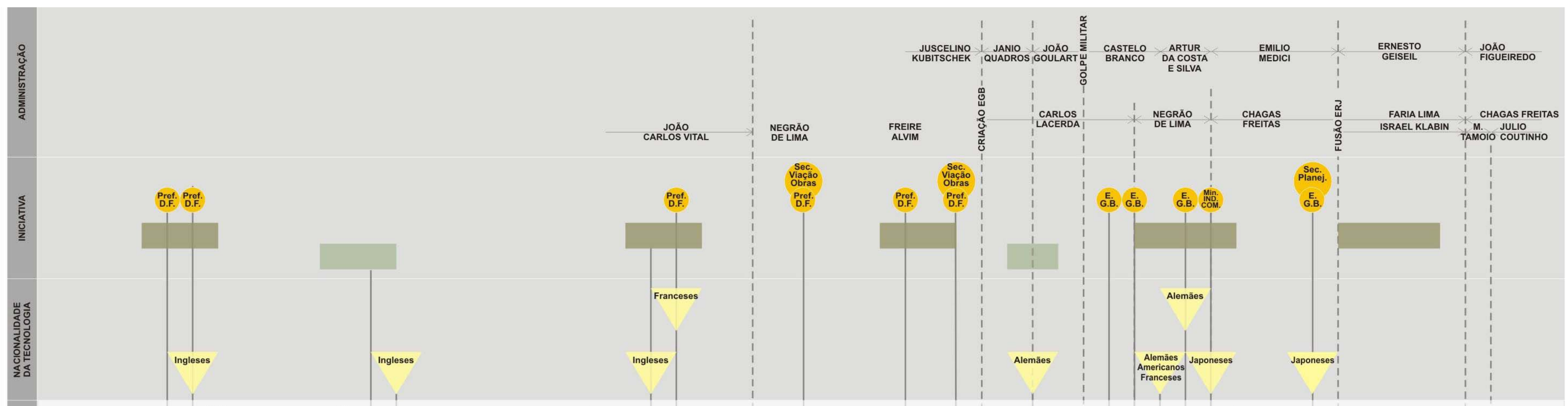

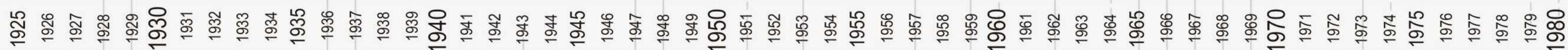

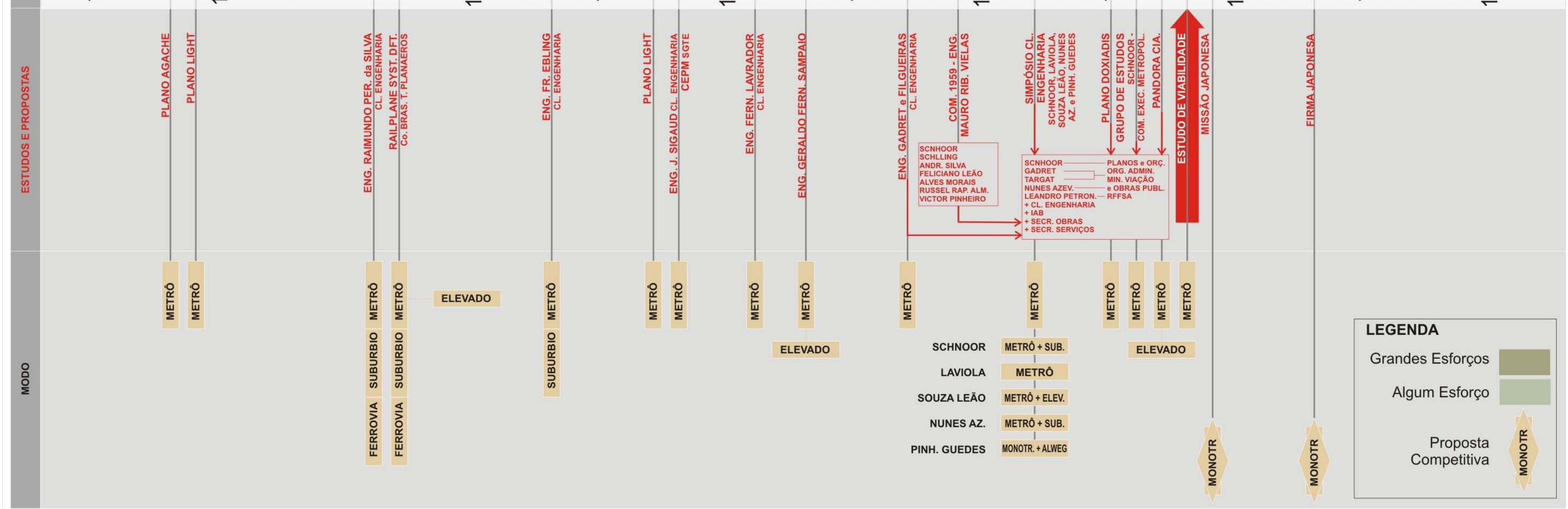


estudos ligados diretamente à administração pública. O trabalho substantivo dessas comissões, que efetivamente conduziu à realização do empreendimento, se concentrou nos últimos dois anos do período. Durante os 18 anos anteriores, embora esses grupos mantivessem viva a idéia do Metrô, sua impotência atestava o desinteresse das administrações em curso, que concentravam seus esforços em outros projetos.

A CEPM - Comissão Executiva do Projeto Metropolitano, criada em dezembro de 1948, na administração do Prefeito General Mendes de Moraes, conseguiu a aprovação, em 1952, durante a administração do Prefeito João Carlos Vidal, da lei que autorizava o Poder Executivo a proceder às operações de desmonte do Morro Antônio, com o objetivo de iniciar a construção de uma rede de trens subterrâneos.

Em 1955, com Negrão de Lima indicado para Prefeito do Distrito Federal, chegou a ser criada a Companhia do Metropolitano do Rio de Janeiro, que emitiu títulos da dívida pública e constituiu diretoria. A Prefeitura reservou, em dezembro de 1957, 10\% do produto das operações bancárias autorizadas para a SURSAN - Superintendência de Saneamento, órgão com grande autonomia financeira, para o início das contratações do Metrô.

Ao final da administração do Prefeito Freire Alvim, em 1959, meses antes da reorganização político-administrativa que criou o Estado da Guanabara, a Companhia do Metrô nomeou uma comissão que iniciou o ante-projeto de um trecho subterrâneo, baseado na proposta francesa da SGTE, ligando a Glória a Engenho de Dentro, passando pelo Centro, além dos estudos para a ampliação da faixa da EFCB. Presentes nessa comissão estavam muitos nomes que, paralelamente, apresentaram sugestões, em geral através do Clube de Engenharia, 
tentando reforçar a necessidade do empreendimento e reunir interesses que viabilizassem a sua implantação ${ }^{22}$.

Em seguida, em 1961, o novo quadro administrativo da gestão Carlos Lacerda, agora na alçada estadual, extinguiu a Companhia do Metrô, restituiu as ações e criou comissão especial para receber o acervo da extinta companhia. Ao revogar as ações já implantadas, a administração Lacerda se posicionou contra o sistema de Metrô e constituiu em 1962 um grupo de trabalho cuja finalidade era estudar conjuntamente os problemas de transportes urbanos e suburbanos da cidade através de estudos mais abrangentes.

A CMTMG - Comissão Mista dos Transportes Metropolitanos da Guanabara, criada em 1962, através da Resolução 29, tinha entre suas atribuições o estudo e a proposição de medidas para a imediata implantação do Metrô; nela não estava presente nenhum dos integrantes já tradicionais nos estudos relativos ao Metrô.

A organização do já citado simpósio do Clube de Engenharia em abril desse mesmo ano é uma resposta à postura da administração Carlos Lacerda, claramente contrária ao Metrô. O Clube de Engenharia se posicionou publicamente, portanto, contra o Governo do Estado no que se refere à política de transportes. Segundo o Vice-Governador à época, Raphael de Almeida Magalhães $^{23}$, a intenção daquela administração era um tratamento de caráter mais abrangente dos problemas de transportes, sendo necessária uma ação integrada junto à RFFSA, que tinha jurisdição sobre a rede de subúrbios, e junto ao FRN - Fundo Rodoviário Nacional, liberando as

\footnotetext{
${ }^{22}$ Dentre eles estavam os engenheiros Jorge Schnoor, Hermínio de Andrade e Silva e Jorge Abreu Schillig, sendo que este último, engenheiro ferroviário, havia apresentado uma crítica às propostas de Ebling e Laviola, indicando a importância de fazer emergir o Metrô nas linhas da EFCB até Deodoro.
} 
verbas do DNER destinadas às estradas, para que o mesmo pudesse ser utilizado em obras urbanas. Entretanto, nenhuma ação concreta foi executada no âmbito dos transportes sobre trilhos, sendo o sistema rodoviário fortemente privilegiado nesse período, com as obras do Aterro do Flamengo, e da ligação Zona Norte - Zona Sul através dos túneis Rio Comprido Cosme Velho e Cosme Velho - Humaitá, conhecido com Túnel Rebouças, numa extensão de cerca de 2,5 km de perfuração das montanhas do maciço da Carioca. A prática contradiz a suposta intenção do governo estadual, assim como tornou sem efeito lei que, no final de 1962, autorizou a emissão de títulos de renda líquida para investimentos em obras das duas linhas do Metrô, pois nada foi realizado no setor dos transportes sobre trilhos.

Negrão de Lima, sucedendo Lacerda no Governo do Estado da Guanabara, voltou a apoiar o Metrô, retomando a idéia de elaborar o projeto definitivo da rede. Os antigos defensores do empreendimento voltaram a se reunir em comissões especiais, sendo de grande importância o Grupo de Estudos criado pelo governador em Junho de $1966^{24}$ que apresentou relatório afirmando a urgência da constituição de órgão específico para o desenvolvimento dos estudos do Metrô. O relatório foi aprovado e a CEPE-2 - Comissão Executiva do Metropolitano do Rio de Janeiro foi constituída em outubro de 1966 que retomou os trabalhos interrompidos, abrindo crédito especial e convocando, no final do mesmo ano, concorrência internacional para os estudos de viabilidade.

Atenderam ao certame 101 firmas organizadas em 17 consórcios e uma firma individual. Foi vencedor o consórcio teuto-brasileiro CCN - Hochtief - Deconsult (Companhia Construtora

\footnotetext{
${ }^{23}$ Entrevista com Rafael de Almeida Magalhães - vice-governador na administração do Governador Carlos Lacerda - feita em 12 mar. 1982. Seu depoimento confirmou que essa administração não teve interesse na implementação de um sistema de transporte público de massa.

${ }^{24} \mathrm{O}$ redator do Grupo de Estudos era o engenheiro Jorge Schnoor, entrevistado em 17 fev. 1982. Engenheiro ferroviário, trabalhou em diversas administrações do Estado do Rio de Janeiro, apresentando propostas para o desenvolvimento ferroviário do estado e na cidade do Rio de Janeiro.
} 
Nacional - Hochtief A. G. Essen - Deutsch Eisenbahn Consulting), sendo o resultado divulgado em julho de 1967.

O contrato com o consórcio CCN - Hochtief - Deconsult foi assinado em agosto de 1967, mas o estudo só começou em fevereiro de 1968. É interessante observar como a partir desse momento, o processo decisório se desenrolou com muita celeridade. Em 11 de junho de 1968, apenas quatro meses depois de iniciados os estudos, o consórcio apresentou a proposta da linha prioritária, que foi aprovada em 24 horas pela CEPE-2 e em 15 dias, no dia 27 do mesmo mês, pelo Governador do Estado da Guanabara, através de despacho oficial, seguindo então para a Assembléia Legislativa, votado em seção extraordinária, num domingo. Os deputados da oposição, à época, alegaram a ilegalidade do processo de aprovação do trecho prioritário do Metrô, acreditando na existência de fortes pressões do Governo Federal para a aprovação rápida do projeto.

Em julho de 1968, a CEPE-2 convocou firmas e consórcios brasileiros interessados na elaboração dos projetos construtivos das obras e sistemas do trecho prioritário, mesmo antes do Estudo de Viabilidade ter sido finalizado. A Comissão executou algumas desapropriações e contratou divulgação na mídia, previamente à constituição da nova Companhia do Metropolitano do Rio de Janeiro, o que aconteceu em novembro de 1968, pela Lei Estadual no. 1.736 .

Tendo como principal acionista o Governo do Estado da Guanabara, a Companhia do Metrô recebeu, em dezembro de 1968, o relatório final do Estudo de Viabilidade e já tinha contratado a consultoria do mesmo consórcio para a coordenação dos projetos executivos, antes mesmo da conclusão dos estudos. Em seguida, contratou projetos de sondagem, arquitetura, engenharia e seus complementares e executou desapropriações. Iniciou 
negociações para obter o aporte financeiro do Governo Federal, que culminou na Exposição de Motivos $n^{0} 106^{25}, 1970$, do Governo Federal. Esse documento estabeleceu a contribuição financeira da União para os Metrôs de São Paulo e do Rio de Janeiro explicitando uma série de condições para a viabilização desses recursos. O Governo Federal pretendia, em troca de recursos, interferir em alguns aspectos da obra no que concerne ao traçado e ao planejamento da construção, alterando assim os resultados do estudo. A Companhia do Metrô contratou as primeiras obras civis, e o dia 23 de junho de 1970 foi a data do início efetivo das obras, comemorado em solenidade de cravação da primeira estaca, imediatamente após a autorização do Governo Federal para realizar operações de empréstimo externo com garantia do Tesouro Nacional até o equivalente a US\$ 110 milhões de dólares. Note-se a intervenção direta do Governo Federal.

Negrão de Lima deixou o governo do estado e na administração seguinte - Chagas Freitas - as obras prosseguiram, porém, em ritmo muito lento. Pouco interessado no andamento e na eventual finalização da obra, o governo Chagas Freitas chegou a cogitar a sua paralisação e a utilização das galerias já abertas para outros fins. Foram realizadas nesse período importantes obras viárias na Zona Sul, melhorando o acesso à Barra da Tijuca. O montante liberado para a obtenção de crédito externo através do aval do Governo Federal, definida pela Exposição de Motivos nº 106 de 1970, acima citada, foi apenas parcialmente utilizado.

Chagas Freitas não teve empenho em garantir o prosseguimento de uma obra por ele não iniciada, que gerava fortes inconvenientes à população e que dificilmente poderia ser

\footnotetext{
${ }^{25}$ Trata-se de Despacho do Presidente da República que aprova a Exposição de Motivos no. 106, de maio de 1970, dos Ministérios de Planejamento, Fazenda e Transportes que outorga aval para operações de financiamento externo até o montante de US\$ 110 milhões para as obras dos Metrôs de São Paulo e do Rio de Janeiro.
} 
concluída no período de sua administração, de forma que não lhe renderia os dividendos políticos de seu interesse. Durante o seu governo, já se previa uma mudança substancial na estrutura político-administrativa com o iminente processo de fusão dos dois estados, Rio de Janeiro e Guanabara, estudado e decidido unilateralmente na esfera federal em 1975. Reconhecida por muitos como “intervenção federal” no Estado da Guanabara, empreendida com a intenção principal de mudar o quadro político considerado de oposição ${ }^{26}$, a fusão trouxe uma série de mudanças administrativas e com elas o intuito de marcar sua época com uma grande obra de caráter urbano - o Metrô RJ. Nessa mesma forma de atuação - decisões dissociadas dos interesses locais - pode-se incluir a implantação da Ponte Rio-Niterói, inaugurada em 1974.

Além da modernização administrativa de caráter tecnocrata, cópia do modelo federal pós1964, a Companhia do Metrô recebeu apreciáveis incentivos financeiros do Governo Federal: na forma dos avais para empréstimos no exterior, das dotações a fundo perdido para o novo estado repassados para a companhia e através da participação acionária da EBTU nas obras. Um grupo de estudos, organizado antes da posse do novo governo e cujos membros iriam ocupar postos chave na administração a partir de 1975, re-estudou o traçado da rede em construção, a tecnologia a ser utilizada e o ritmo de construção. O grupo sugeriu uma série de alterações no traçado, na gerência e na implantação e, a partir de 1975, com o governo estadual comandado por Faria Lima, as obras e os projetos complementares se desenrolaram rapidamente com o objetivo de inaugurar o trecho prioritário antes do término do primeiro mandato da fusão. Durante esse período, a Companhia do Metrô foi soberana nas suas decisões e bastante independente de outros órgãos da administração e das elites locais, uma

\footnotetext{
${ }^{26}$ A entrevista de Josef Barat, realizada em 25 mar. 1981, 03 abr. 1981, 06 abr. 1981 e 08 abr. 1981, tratou extensivamente do tema, assim como o livro de BRASILEIRO, A. M. A Fusão: Análise de uma Política Pública, IPEA. Série Estudos para o Planejamento, no. 21. Brasília, 1979. 364 p.
} 
vez que dispunha de uma autonomia de recursos considerável, proveniente direta ou indiretamente do Governo Federal. Obedecia ao modelo de criação de estatais permitido a partir do DL 200/1967.

A implantação do sistema prosseguiu rapidamente e a administração Faria Lima conseguiu inaugurar em 1979 um pequeno trecho inicial de linha, pouco mais de 4 km, da Praça Onze à Gloria, passando pelas estações Central, Presidente Vargas e Cinelândia, e deixou a construção iniciada em grande parte da rede, com obras em diferentes fases de execução, para que fossem concluídas nas administrações seguintes. A Companhia do Metrô optou pela estratégia de iniciar as obras em toda a extensão da linha prioritária, de modo a tornar a sua implantação irreversível fixando definitivamente o seu traçado.

Chagas Freitas, que constituiu uma gestão considerada de oposição ao Governo Federal, reassumiu em 1980 o governo do estado - agora do novo Estado do Rio de Janeiro - e o ritmo de implantação da rede do Metrô foi mais uma vez substancialmente reduzido. O quadro financeiro também sofreu modificações de modo que os recursos para o Metrô diminuíram drasticamente, não tanto pelas divergências políticas entre o estado e o Governo Federal, mas pela situação de crise financeira que atingiu a nação a partir de 1979, crise que começou a ser sentida até mesmo pela Companhia do Metrô, já no final do Governo Faria Lima.

A empresa perdeu o seu poder quase absoluto de decisão e ficou sujeita, não só aos atritos entre as lideranças políticas mas, especialmente, às novas dificuldades de obtenção de crédito externo e interno que tenderam a se agravar rápida e fortemente. Chagas Freitas inaugurou alguns trechos que já se encontravam em fase final, paralisando outros e chamando a atenção do Governo Federal para a situação crítica de endividamento da companhia. Tentou negociar 
a responsabilidade da implantação da obra com o Governo Federal, oferecendo-lhe a soberania sobre a companhia - poder de decisão e de gestão -, justificando através da impossibilidade do Governo do Estado em arcar com o endividamento e dar prosseguimento às obras. Sua estratégia teve um sucesso parcial, com a liberação de um montante de recursos a fundo perdido, que permitiu aliviar uma parte das dívidas. E a crise continuou até a concessão à iniciativa privada do sistema em 1998.

Durante estes 19 anos em que a operação comercial permaneceu sob a responsabilidade da Companhia do Metrô, foram construídas e implantadas 15 estações da Linha 1, interligando Botafogo à Tijuca, nas seguintes datas:

1979 - Estações Praça Onze, Central, Presidente Vargas, Cinelândia e Glória; 1980 - Estações Uruguaiana e Estácio;

1981 - Estações Carioca, Catete, Morro Azul (atual Flamengo), Botafogo e Largo do Machado;

1982 - Estações Afonso Pena, São Francisco Xavier e Saens Penã;

e 9 estações da Linha 2, do Estácio a Vicente de Carvalho, nas seguinte datas:

1981 - Estações São Cristóvão e Maracanã;

1983 e 1984 - Estações Maria da Graça, Del Castinho, Inhaúma e parcialmente Irajá;

1988 - Estação Triagem;

1991 - Estação Engenho da Rainha e

1996 - Estações Tomás Coelho e Vicente de Carvalho.

Já no período de concessão foram inauguradas as seguintes estações da Linha 1:

1998 - Estação Cardeal Arcoverde;

2002 - Estação Siqueira Campos; 
2006/2007 - Estação Cantagalo;

e na Linha 2 foram inauguradas as seguintes estações:

1998 - Irajá, Colégio, Coelho Neto, Eng. Rubens Paiva, Acari/Fazenda Botafogo e

Pavuna.

\subsection{Estudo de Viabilidade do Consórcio CCN - Hochtief - Deconsult ${ }^{27}$}

O consórcio vencedor da concorrência internacional elaborou o "Estudo de Viabilidade Técnica e Econômica para o Metropolitano do Rio de Janeiro”, em relatório de 581 páginas, realizado entre fevereiro e dezembro de 1968 em cooperação direta com a CEPE- $2^{28}$.

O estudo teve por objetivo selecionar o sistema de transporte rápido de massa mais adequado para o Rio de Janeiro e determinar sua viabilidade técnica e econômica num horizonte prospectivo de 20 anos. Deveria projetar a rede para o ano 1990 e selecionar a linha de prioridade absoluta dentro do sistema proposto que pudesse ser implantada no curto prazo, de modo a aliviar a cidade de suas maiores pressões de tráfego. Esta linha prioritária deveria ser pré-planejada tecnicamente, antecedendo a fase de contratos de projetos executivos de cada trecho.

\footnotetext{
${ }^{27}$ CCN - HOCHTIEF - DECONSULT. Study of Technical and Economic Feasibility of the Metrô of Rio de Janeiro. Rio de Janeiro, dez. 1968. 581 p.

${ }^{28}$ Cabe observar a presença vários profissionais brasileiros na equipe técnica do Consórcio, como consultores, dentre eles alguns ligados a estudos anteriormente elaborados sobre o Metrô do Rio de Janeiro como o eng. Antonio Laviola e o eng. Fernando Lavrador. Outros profissionais notáveis como Oscar Niemeyer também participaram como consultores. Foram sub-contratadas várias empresas nacionais: Geotécnica SA - Engenheiros Consultores, IBOPE - Instituto Brasileiro de Opinião Pública e Estatística, IES - Instituto de Engenharia Sanitária da Secretaria de Obras Públicas do Estado da Guanabara, IPT - Instituto de Pesquisas Tecnológicas, PUC - Pontifícia Universidade Católica do Rio de Janeiro, SPLAN - Sociedade de Pesquisas e Planejamento, Tecnosolo - Engenharia e Tecnologia de Solos e Materiais SA e Valit - Empresa Técnica de Avaliações e Pesquisas. Era também sub-contratada a IBM - Deutschland.
} 
Ainda dentro do contrato firmado entre o Governo do Estado da Guanabara e o consórcio CCN - Hochtief - Deconsult, o estudo deveria conter indicações da rentabilidade do empreendimento, através da indicação das relações custo-benefício nas diversas fases de implantação, e um plano de financiamento, com indicações das principais fontes domésticas e externas. No planejamento do sistema operacional, o estudo deveria aconselhar, na medida do possível, produtos nacionais para a instalação e manutenção do sistema.

A área dos estudos compreendia o Município do Rio de Janeiro e seis outros municípios vizinhos $^{29}$ - Niterói, São Gonçalo, Duque de Caxias, São João de Meriti, Nilópolis e Nova Iguaçu - num total de $2.100 \mathrm{~km}^{2}$, com uma população de cerca de seis milhões de habitantes, chamada de Macro-Área. Dentro da Macro-Área, um espaço de 128 km², chamada de MicroÁrea, foi escolhida para os estudos mais detalhados, já que apresentava os maiores volumes de tráfego. Na Micro-Área seriam estimadas as projeções e conseqüentemente estabelecidos os requisitos de tráfego para o ano 1990, incluindo um sistema de transporte rápido de massa. A linha prioritária, dentro da Micro-Área deveria ser planejada como primeira etapa de construção do Metrô, num horizonte de sete anos, ou seja, 1975, respondendo às necessidades mais urgentes.

Realizados os estudos através de métodos clássicos, o Consórcio concluiu que a cidade do Rio de Janeiro tinha necessidade imperativa de um sistema de transporte rápido de massa e propôs, para 1990, o sistema de 67 km de vias, com 55 estações, distribuídas em 2 linhas:

- Linha 1 com 37 km, de Ipanema até a Baixada de Jacarepaguá passando pelo Centro, sendo de Ipanema até o Méier em sistema subterrâneo e, a seguir, em sistema elevado até a Baixada de Jacarepaguá, área que ainda apresentava baixa densidade

\footnotetext{
${ }^{29}$ O estudo é anterior a criação da Região Metropolitana do Rio de Janeiro - 1974 - e não inclui todos os municípios compreendidos pela mesma.
} 
demográfica. Esta linha contém o trecho prioritário, de Ipanema até a Tijuca, subterrâneo, a ser posto em operação até 1975 e

- Linha 2 com 30 km, da Pavuna até Niterói, sendo em superfície da Pavuna até o Centro ao longo do leito da linha desativada da ferrovia Rio d’Ouro, encontrando a linha 1 e seguindo até Niterói em túnel sob a Baia de Guanabara. Esta linha cruzaria a Linha 1 em duas estações - Estácio e Largo da Carioca.

O sistema assim idealizado se integraria à rede de subúrbios em 9 estações. O trecho prioritário Ipanema-Centro-Tijuca, subterrâneo, possibilitaria o deslocamento em 32 minutos e conexão com os trens de subúrbio na Estação Ferroviária D. Pedro II, principal estação da EFCB. Esse trecho teria cerca de 20 km com 22 estações numa distância média de 0,860 km entre elas e com bitola de 1.60 m, coerente com o sistema ferroviário da cidade. Possibilitaria a diminuição expressiva do número de ônibus que servia a área central. Estes perderiam assim sua função estrutural no sistema de transporte de massa, continuando entretanto, indispensáveis no papel de alimentadores do sistema de Metrô e como sistema suplementar, para o tráfego tangencial. Os trechos de maior tráfego seriam, na linha 1, Cinelândia-Carioca, com 48.000 passageiros previstos por direção por hora-pico e na linha 2, Estácio-Mangueira, com 62.000 passageiros por direção por hora-pico.

O estudo também apresentava alternativas para extensão do sistema com integrações adicionais da rede metroviária com as ferrovias, na linha 1 até Deodoro, Santa Cruz e Nova Iguaçu e na linha 2 até Belfort Roxo e Duque de Caxias, numa extensão de 133 km de rede integrada, com 95 estações. 
Na determinação do sistema utilizou-se o método clássico de “Model Prognosis” para gerar a distribuição futura do tráfego na área em questão, através de uma projeção de tendências. Foram selecionados dois horizontes para as projeções, 1975 e 1990, assumindo para a cidade do Rio de Janeiro as tendências de desenvolvimento que a região já apresentava, nem um crescimento explosivo e nem o esvaziamento econômico.

Para a determinação da correlação entre distribuição de tráfego e fatores que o geram, foram analisados os dados existentes sobre uso do solo, população, distribuição de empregos, localização de escolas, renda, evolução dos autos particulares etc. Foram escolhidos como mais significativos e operacionais os parâmetros: população, emprego, localização de escolas e número de automóveis particulares. A coleta de dados se constituiu num aspecto crítico para o estudo, pois o último censo, datado de 1960, apresentava dados antigos (oito anos - intervalo considerado excessivo). Dados recolhidos pela administração estadual em 1964 e 1965, através dos “Estudos Cariocas”, Coordenação de Planos e Orçamento, 1965, Volume 5, foram disponibilizados para o Consórcio mas foram posteriormente considerados obsoletos, dado o desenvolvimento da região nos anos que se seguiram.

Para minimizar distorções da base de dados, o Consórcio realizou numerosas contagens de tráfego e entrevistas com passageiros de diversos modos de transporte e em 4.000 residências. Não existia à época nenhum plano de uso do solo em vigor, que pudesse dar indicação do crescimento futuro e das principais obras viárias que possivelmente seriam realizadas. Pôdese observar posteriormente que as também projeções quanto à evolução da população e quanto ao índice de motorização foram subestimadas para os dois horizontes. 
Esses dados, mesmo com imperfeições e problemas, foram utilizados para as estimativas do futuro volume de tráfego e sua repartição modal através do modelo a quatro etapas: Geração de Tráfego, Distribuição de Tráfego, Distribuição Modal e Traffic Assignment. Para o ano de 1990, os resultados previram mais do que uma duplicação do tráfego total existente em 1968.

Foi então testada a Performance Capability que os meios de transporte, o sistema rodoviário e ferroviário poderiam apresentar em 1990, depois de executados alguns projetos de expansão viária, idealizados no âmbito desse mesmo estudo, uma vez que não existia plano de uso do solo. O resultado demonstrou que mesmo com um sistema ferroviário de alto desempenho, aliado a um serviço de ônibus com expansões a serem realizadas até 1990, não se conseguiria acomodar o volume de tráfego em horas de pico previsto através do modelo. Assim, o estudo concluiu pela necessidade imperativa da implantação do Metrô, uma vez que nenhuma alternativa poderia ser oferecida ao transporte individual, sendo inclusive impossível expandir o sistema viário indefinidamente sem prejudicar a estrutura urbana. Foi recomendada então a construção do Metrô, a ser operado independentemente do restante do tráfego.

Procedeu-se a seguir ao Planejamento Técnico, para a seleção de um sistema metroviário capaz de responder aos requisitos que os prognósticos do planejamento de tráfego requeriam, em termos de equipamento e de localização das linhas.

Comparando-se os custos (de capital e operacionais) com os benefícios (receita operacional do sistema para as datas horizonte), concluiu-se pela viabilidade do empreendimento que, mesmo antes de 1990, ou seja, mesmo antes do sistema totalmente implantado e em operação, renderia benefícios que já contrabalançariam os custos, incluindo todo o capital e os interesses do mesmo. 
A estimativa de custos constante do estudo - que se mostrou mais tarde muito diferente dos custos reais - apresentava um valor total de US\$ 725,00 milhões para a implantação da totalidade do sistema $(67 \mathrm{~km})$, com a seguinte composição: 5\% para desapropriações, 57\% para obras civis e 38\% para via permanente, veículos e os sistemas, resultando então num valor médio de US\$ 10,82 milhões/km. A linha prioritária teria um custo por km mais alto, US\$ 15 milhões, dados os investimentos em pátio de manobra que deveriam ser feitos desde o início, bem como devido à sua localização em zona mais valorizada.

O prazo para a realização do estudo foi considerado pelos próprios contratados como muito curto para a elaboração de todas as etapas do mesmo, seguindo-se a seqüência lógica acima descrita. Assim, ao mesmo tempo em que se produzia o planejamento de tráfego (que determinaria o volume de tráfego futuro que só então poderia ser comparado à performance capability do sistema de transporte existente e otimizado, definindo a necessidade ou não de um sistema de transporte rápido de massa), produzia-se o planejamento técnico definindo o sistema adequado, o equipamento e o traçado, admitindo-se portanto, a priori, a necessidade de um sistema de transporte rápido de massa.

Várias hipóteses foram feitas, aguardando os resultados do processamento dos dados, entre as quais a hipótese de necessidade de uma linha de Metrô. Mais tarde, com a ajuda dos resultados dos modelos computacionais, essas hipóteses puderam ser verificadas e corrigidas. Ainda de acordo com o próprio relatório oficial da CCN - Hochtief - Deconsult, uma proposta para a linha prioritária teria que ser submetida depois de quatro meses de trabalho, de modo a possibilitar a elaboração do pré-projeto no tempo contratual, prazo considerado pela empresa como muito exíguo. 
Pode-se concluir que houve um movimento constante ao longo do período de 1927 a 1968 de se propor a construção de um sistema metroviário. Foi a Companhia Light, que já tinha uma atuação muito forte na cidade, que apresentou as duas propostas mais firmes que desoneravam o poder público da implantação do sistema. Engenheiros especialistas no setor ferroviário, com muito conhecimento do setor no Rio de Janeiro apresentaram a maior parte das idéias. Podemos afirmar também que poucos, dentre esses estudos, foram solicitados pela administração pública, constituindo iniciativas isoladas do contexto institucional, e que não foram determinantes das decisões sobre os transportes públicos na cidade.

A Prefeitura do Distrito Federal trouxe o grupo francês, liderado pela SGTE, cujo estudo chegou muito perto de embasar uma decisão concreta. Foi só no final da década de 1960, enquanto Estado da Guanabara, e já durante a fase do regime autoritário no Governo Federal pós 1964, que a decisão foi formalmente tomada e lastreada nos estudos do grupo alemão, associado a uma empresa construtora nacional, que concorreu com grupos de outras nacionalidades. 
CAPÍTULO 06 


\section{TRAÇADO, RECURSOS FINANCEIROS E CONSTRUÇÃO}

Este capítulo apresenta uma reconstituição do processo de implantação do sistema metroviário da cidade do Rio de Janeiro nos aspectos mais centrais quanto à tomada de decisão. Além da decisão principal de se construir um Metrô, qual seria o melhor traçado, quais seriam as fontes de financiamento mais adequadas e qual seria o tipo de construção que melhor atenderia aos objetivos de sua implantação? Esclarecimentos sobre esses três pontos principais: traçado, recursos financeiros e construção podem elucidar a eventual rede de interesses a orientar as decisões.

\subsection{A Evolução do Traçado}

Através das ilustrações, que no capítulo anterior apresentam os principais estudos realizados, pudemos observar que no período de 40 anos de estudos e propostas efetivas, existiu um relativo consenso quanto à necessidade da ligação Zona Sul - Zona Norte, passando pelo Centro, a ser solucionada por uma linha de transporte rápido de massa. É evidente a coincidência de traçado entre essa linha proposta em 1929 e parte do sistema idealizado em 1968, através do Estudo de Viabilidade e implantado prioritariamente. As variações de traçado se concentram nas extensões do sistema, que diferem segundo os agentes interessados na aprovação do estudo e na seqüência de implantação. Enquanto se tratou de convencer o poder público da conveniência de um transporte de massa eficiente para toda a cidade, os traçados foram mais extensos e os estudos mais abrangentes quanto às demais possibilidades modais e suas integrações. É o caso dos trabalhos produzidos pelos engenheiros cariocas veiculados pelo Clube de Engenharia antes do surto automobilístico, dentro da visão predominantemente ferroviarista dos transportes públicos. A implantação de um trecho na 
área central, através de um metrô, era consensual, e as extensões se davam pelas ferrovias chegando até Jacarepaguá e Santa Cruz, numa abordagem, à época, de caráter quase regional, ou seja, avançando muito além da área mais densamente urbanizada.

Quando se tratou de lutar contra a lógica rodoviarista, que muito influenciou a administração pública a partir da segunda metade do século XX, os estudos e propostas para o metrô foram menos abrangentes do ponto de vista territorial e mais localizados quanto à urgência da construção da linha central, desvinculando assim, o metrô do sistema ferroviário em geral. Este último, na competição com o sistema rodoviário por recursos públicos, era perdedor. Esta abordagem mais específica e com uma conotação de modernidade, foi a de Negrão de Lima, enquanto Prefeito do Distrito Federal e enquanto Governador do Estado da Guanabara, nos dois períodos que mais favoreceram as decisões para a implantação do Metrô-RJ.

Alguns técnicos anteviam as dificuldades na construção de uma linha subterrânea nas áreas mais densas da cidade, fato que alimentou durante algum tempo uma polêmica entre defensores da construção nessas áreas e daqueles que recomendavam um traçado pelas encostas dos morros ou na beira do mar, no que é hoje o Aterro do Flamengo, tangenciando assim o corredor formado pela planície densamente ocupada ${ }^{1}$. Estas soluções tangenciais prescreviam redes elevadas ou de superfície, condicionando assim a tecnologia a ser empregada.

\footnotetext{
${ }^{1}$ Neste sentido, vários técnicos se pronunciaram, sendo de especial interesse as observações do eng. Jorge Schnoor, que propôs a execução do trecho de Copacabana junto à encosta, reduzindo substancialmente os custos de desapropriação e os incômodos para um grande número de pessoas durante a construção conforme matéria Técnico sugere metrô pela encosta, publicada no Jornal do Brasil em 12 jun. 1977. Durante algum tempo os técnicos do Metrô tiveram que afirmar categoricamente que os túneis do Metrô eram totalmente seguros quanto ao risco de inundação, seja através do lençol freático quanto com relação a chuvas, o que pode ser observado em diversas declarações para a imprensa, destacando-se Barat assegura que o metrô jamais sofrerá inundações, matéria publicada em O Globo, 17 jan. 1976.
} 
A maior parte das comissões ou grupos de estudos oficiais defendia soluções clássicas subterrâneas, atitude previsível em função da grande penetração da companhia francesa SGTE na administração pública e das missões francesas, compostas por técnicos e empresários, que nas décadas de 1950 e 1960 aconselharam as comissões técnicas brasileiras. Ingleses, alemães e japoneses tentaram intervir com soluções de superfície ou elevadas, do tipo Alweg ou monotrilho, respondendo assim a traçados menos convencionais. Posteriormente, já na década de 1970, os japoneses aconselharam a utilização do sistema monotrilho afastando-se do traçado pela zona central - para onde a escolha de traçado e de equipamentos já estava comprometida -, recomendando as ligações Ilha do Governador a Jacarepaguá ou Estácio a Pavuna, distantes dos problemas das áreas super carregadas em deslocamentos.

Finalmente, a concorrência internacional, que em 1968 decidiu pelo consórcio teuto-brasileiro CCN - Hochtief - Deconsult para a elaboração do Estudo de Viabilidade - base para a tomada da decisão definitiva - viabilizou o traçado mais tradicional para a linha 1, Tijuca-Ipanema, trecho prioritário passando pelo Centro. Ver Ilustração 17 - Traçado do Estudo de Viabilidade 1968.

Como já vimos, o estudo de 1968 propunha a rede completa com 67 km, através da extensão da linha 1 - da Tijuca em direção ao Méier, seguindo para Jacarepaguá - e da construção da linha 2 - Niterói a Pavuna -, utilizando-se o leito da antiga Ferrovia Rio d’Ouro e trecho sob a baía. Para se chegar às conclusões finais quanto ao traçado descrito pelo Estudo de 1968, o consórcio elaborou um estudo sofisticado, em tempo recorde, mas que apontou para um traçado já consagrado ao longo do tempo. 


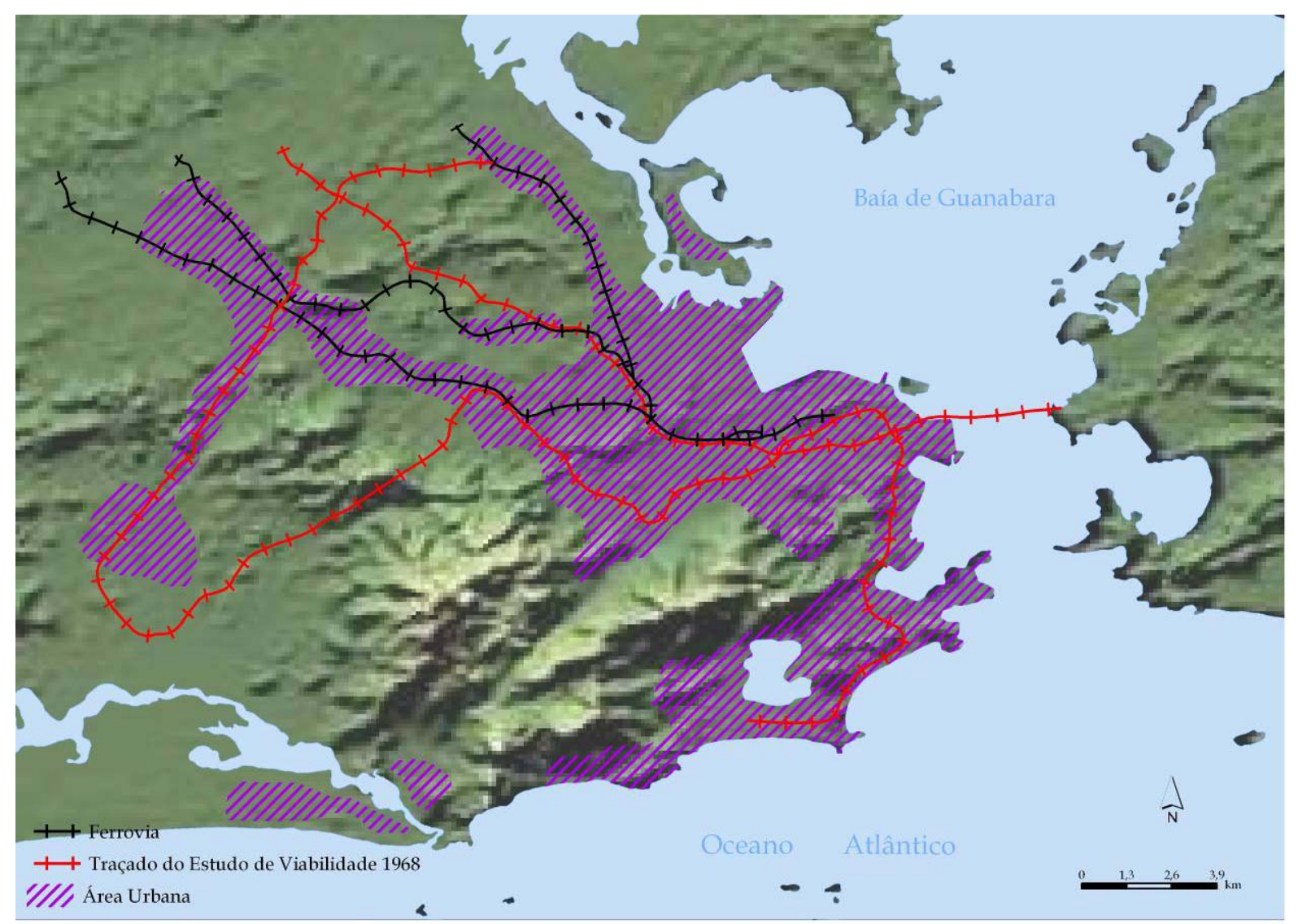

Referência: CCN - HOCHTIEF - DECONSULT. Study of Technical and Economic Feasibility of the Metrô of Rio de Janeiro. Rio de Janeiro, dez. 1968. 581 p.

\section{Ilustração 17 - Traçado do Estudo de Viabilidade 1968}

Na situação particular do Rio de Janeiro, devido aos condicionantes do relevo e à localização das principais atividades, pode-se afirmar que qualquer estudo levaria à definição do mesmo trecho central, coincidente àquele gerado pelos estudos durante 40 anos, baseados apenas no bom senso, sem nenhuma técnica de análise mais complexa.

O Estudo de Viabilidade de 1968, formalmente elaborado de acordo com a racionalidade apresentada pelo método mencionado, foi amplamente utilizado pelo grupo político no poder, como instrumento de legitimação de um traçado e de uma tecnologia, no interesse de ver o projeto aprovado. As suas condições de elaboração e encaminhamento levam a crer que o Estudo de 1968 foi feito para que a implantação do Metrô-RJ fosse unanimemente aprovada; 
não discutiu questões maiores relativas aos transportes urbanos da cidade e o uso alternativo dos recursos financeiros que poderiam eventualmente ser destinados a outras soluções que atingissem um maior número de usuários do transporte público. No entanto, o estudo não se furtou a recomendações relativas a melhorias no sistema ferroviário de atendimento aos subúrbios - eixo com maior número de deslocamentos -, mas propôs um sistema de metrô independente do sistema ferroviário. Na direção dos subúrbios, o estudo criava um novo eixo de transportes, praticamente paralelo aos eixos ferroviários existentes e bastante saturados, numa região de baixa densidade, onde o metrô seria um elemento estruturador do crescimento urbano e até mesmo gerador de demanda, mas que em nada aliviaria as pressões de tráfego existentes nessa direção - trecho norte da Linha 2 (Estácio - Pavuna), no traçado da Estrada de Ferro Rio d'Ouro, desativada.

Assim, o estudo de 1968 não resultou num diagnóstico compreensivo sobre os transportes como o seu item Análise previra. Não discutiu um conjunto de possibilidades para os eixos mais sobrecarregados que pudesse melhorar o tráfego de superfície, como por exemplo: soluções de engenharia de tráfego, corredores exclusivos para ônibus, comboios, trólebus etc.; soluções menos custosas que pudessem liberar mais recursos no atendimento das áreas mais desprovidas, como as áreas suburbanas na direção da Baixada Fluminense.

O escopo desse estudo chegou a ser discutido e contestado pela oposição parlamentar na época de sua aprovação ${ }^{2}$, que argumentava sobre a falta de abrangência do relatório quanto à situação global dos transportes urbanos na região ${ }^{3}$.

\footnotetext{
${ }^{2}$ Informações recolhidas em entrevistas com: Raphael de Almeida Magalhães datada de 12 mar. 1982 e Mauro Magalhães, de 10 mar. 1982, deputados da base oposicionista. Nas palavras de Mauro Magalhães: “A oposição se posicionou contra o projeto alegando que seria mais interessante um metrô menos caro por km e mais longo, em percurso que proporcionasse um atendimento a um maior número de pessoas do que esse que estava sendo proposto. Propunham uso alternativo do investimento que atingisse um maior número de usuários. Tinham algumas idéias de percurso: sair de Campo Grande, percorrer o leito da Central em superfície, mergulhar no Centro e aparecer em superfície de novo no Flamengo. Não existiam técnicos por trás dessa idéia.”
} 
Como já vimos, apesar de decidida e aprovada a implantação do Metrô-RJ em 1968, com o respaldo técnico do Estudo de Viabilidade, o governo do Estado da Guanabara não tinha suficiência financeira para empreendê-lo. Só quando consegue o aval do Governo Federal para créditos externos, sendo que uma das condições para esse aval foi um conjunto de recomendações a serem cumpridas pela Companhia do Metrô e pelo Governo do Estado, elaboradas pelo Grupo de Trabalho da Fusão criado com membros dos Ministérios do Planejamento, da Fazenda e dos Transportes, dentre as quais algumas relativas ao traçado. Reconhecem a necessidade da Linha Prioritária (Nossa Senhora da Paz - Saens Peña ou Ipanema - Tijuca), mas recomendam a realização de estudos complementares para definir os trechos da Linha Prioritária a serem construídos inicialmente e a exigência de que a construção de novas linhas, no futuro, fosse precedida de estudos de viabilidade específicos para cada linha, e ainda da elaboração e aprovação de um Plano Diretor Urbanístico para a cidade. A Exposição de Motivos explicitava também que a integração física e tarifária do Metrô com o sistema ferroviário urbano, sugerida no relatório de viabilidade, carecia de estudos amplos e detalhados que deveriam ser conduzidos de forma coordenada pelas instituições diretamente ligadas ao assunto.

Em seguida, o Grupo de Trabalho constituído previamente ao Governo da Fusão alterou significativamente a prioridade do traçado inicial, tanto do Estudo de Viabilidade quanto das recomendações da Exposição de Motivos no. 106, pois decidiu pela restrição do percurso na direção da Zona Sul - o metrô passaria a ter como terminal sul o bairro do Botafogo, excluindo-se

\footnotetext{
${ }^{3}$ Os motivos da oposição parecem a priori bastante pertinentes mas, quando se examina mais atentamente os membros que a constituíam e a ausência de técnicos do setor no embasamento dessas idéias, pode-se concluir que suas razões não eram realmente a falta de abrangência dos estudos que justificavam o voto contrário mas sim, sua oposição ao metrô, favorecendo claramente o transporte rodoviário e as grandes obras viárias que permitiriam o funcionamento desse setor. O governo anterior, de Carlos Lacerda, do qual vários integrantes vieram a compor, na época, a oposição parlamentar, favoreceu amplamente as obras rodoviárias e o aumento da acessibilidade para novas frentes de ocupação urbana, com a conseqüente valorização imobiliária, conforme descrito nos capítulos anteriores, pouco tendo contribuído para a melhoria do transporte de massa.
} 
da prioridade os bairros de Copacabana e Ipanema - e pela expansão na direção dos subúrbios. Ver Ilustração 18 - Traçado definido pelo Grupo da Fusão. Trata-se de uma alteração muito importante, pois o grupo recomendou a implantação em caráter prioritário do trecho estudado na direção Estácio - Pavuna, neste caso em tecnologia de metrô de superfície, na forma de um PréMetrô, inicialmente com baixa capacidade e com mais baixo custo de implantação.

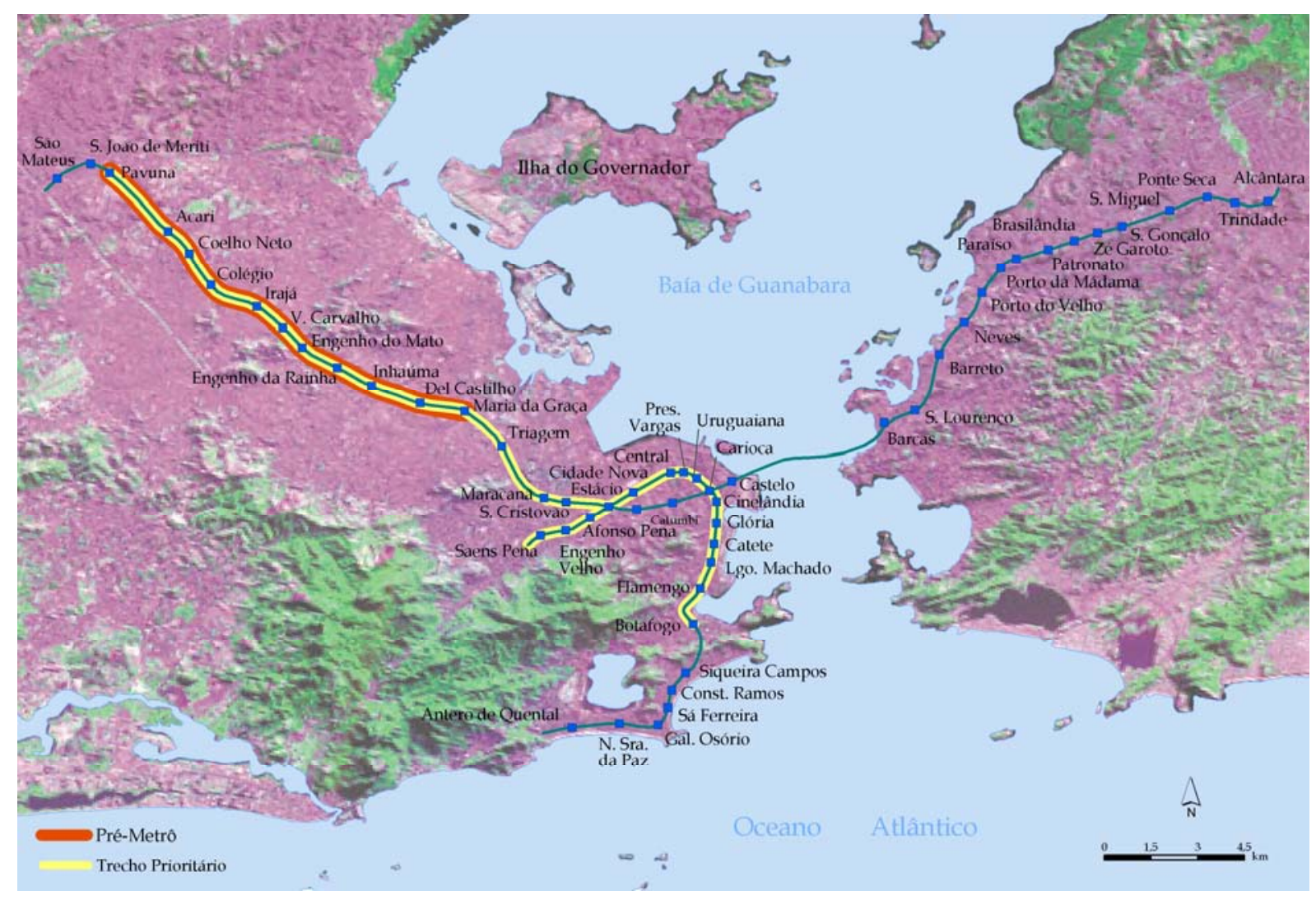

Referência: COMPANHIA DO METROPOLITANO DO RIO DE JANEIRO. Livro Histórico do Metrô. Rio de Janeiro [s.n.], 1977.

\section{Ilustração 18 - Traçado definido pelo Grupo da Fusão}

A área que a proposta da linha do Pré-Metrô (atual linha 2) atravessava era pouco densa e a implantação de um sistema de trânsito rápido cruzando essa área foi tecnicamente justificada pelo Governo da Fusão através de dois argumentos. Ver Ilustração 19 - Traçado do PréMetrô. O primeiro, a função estruturadora que um eixo de transportes poderia ter numa área ainda parcialmente ocupada, cujo espaço poderia ser planejado, numa experiência que, à 
exceção dos eixos estruturadores de Curitiba, seria inédita no Brasil ${ }^{4}$. Em segundo lugar, os técnicos do Grupo de Trabalho da Fusão acreditavam que, com o Pré-Metrô, seria possível uma utilização muito mais intensa do trecho central do Metrô, configurando uma extensão do transporte de massa na direção dos subúrbios, o que daria um caráter social à obra, de grande importância política. Entretanto, mesmo que o traçado da linha 2 se orientasse no sentido das áreas ocupadas por uma população de menor poder aquisitivo, correndo paralelamente aos eixos existentes - rodoviário e ferroviário - e bastante saturados, a sua localização específica não possibilitaria um alívio imediato nos deslocamentos que ocorriam nestes eixos. Esse eixo paralelo estava distante das regiões mais densamente ocupadas, impossibilitando deslocamentos a pé para as estações. Somente com um importante esforço de planejamento de transportes seria possível estabelecer as integrações entre modos - Pré-Metrô e ônibus e PréMetrô e EFCB (Linha Auxiliar) na estação Pavuna - que poderia reduzir o carregamento da Avenida Brasil e dos eixos rodoviários que levam a São João do Meriti e Nilópolis 5 .

A longo prazo, e numa conjuntura de recursos mais abundantes, essas justificativas poderiam ser tecnicamente defensáveis, porém, no curto prazo, uma considerável soma de recursos estaria sendo investida sem que efetivamente se melhorasse a qualidade dos deslocamentos para os subúrbios e para a Baixada Fluminense ${ }^{6}$.

\footnotetext{
${ }^{4}$ Segundo entrevista de Josef Barat em 03 abr. 1981, o Pré-Metrô poderia induzir, a longo prazo, uma ocupação na área vazia das adjacências da Rio d'Ouro na medida em que se integrasse com o sistema de ônibus. O crescimento da metrópole poderia se dar para o fundo da baía, em área adequada e desocupada, de forma integrada ao Metrô. Barat informou também que nessa época foram feitas reuniões com técnicos do BNH, com o intuito de viabilizar conjuntos habitacionais de baixa renda em glebas na vizinhança da linha do Pré-Metrô. Vários artigos na imprensa reforçam a existência de negociações junto ao BNH.

${ }^{5}$ A partir da observação da documentação de planejamento da Companhia do Metro e das declarações à imprensa, em nenhum momento pode-se perceber ações efetivas de implantação de um modo complementar ao Metrô e alimentador do sistema de forma a atender a essa demanda, próxima, mas deslocada da linha do PréMetrô.

${ }^{6}$ Os recursos seriam substanciais mesmo prevendo-se para esse trecho o uso de técnicas menos sofisticadas, como o Pré-Metrô. Correndo na superfície e com freqüência muito mais baixa do que o Metrô, na realidade, o Pré-Metrô custou muito mais do que o previsto mesmo com as simplificações técnicas incorporadas. Segundo
} 


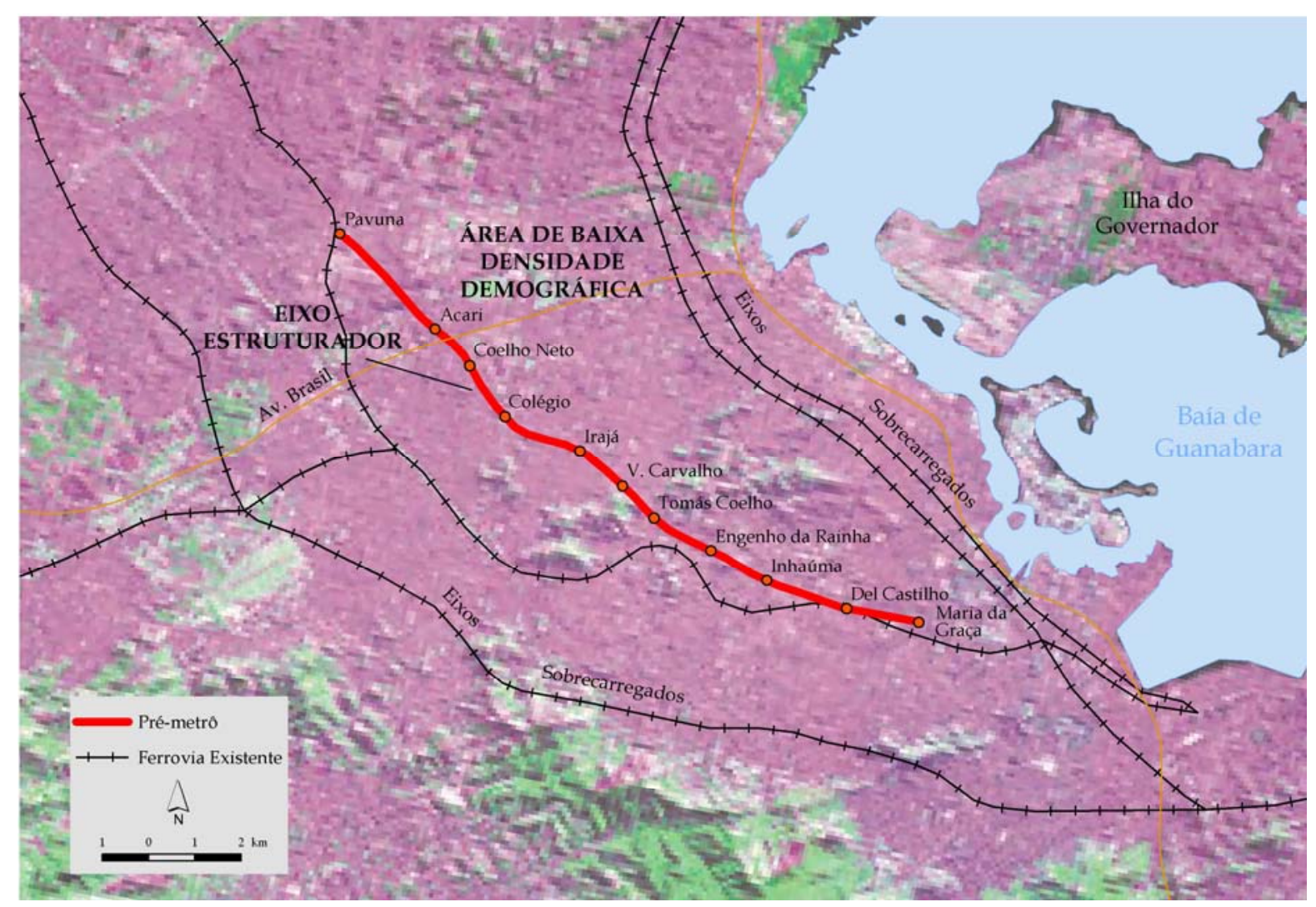

\section{Ilustração 19 - Traçado do Pré-Metrô}

As razões apresentadas para a proposta de construção da linha do Pré-Metrô no trecho selecionado não permitem afirmar categoricamente que essa opção tenha sido fundamentada unicamente em aspectos técnicos, pois trazia em si uma conotação de caráter político. Ao mesmo tempo em que se direcionava uma parte do investimento para regiões mais pobres, o governo estadual não estaria interferindo em assuntos de competência federal - os serviços de transportes suburbanos prestados através da RFFSA. Obviamente, a cidade necessitava de investimentos maciços na rede de subúrbios, o que não estava sendo feito. Desta forma, as críticas que rotulavam o Metrô-RJ como uma obra para as classes médias e médias altas, alheia à grande massa empobrecida, poderiam ser reduzidas. Os técnicos do Metrô-RJ ${ }^{7}$

entrevista com Josef Barat, em 06/04/1981, as simplificações não foram efetivamente implementadas e o trem do Pré-Metrô, por exemplo, teve um custo incompatível com o planejado.

${ }^{7}$ Entrevistas com Leandro Petronilho - Diretor de Engenharia da Cia do Metrô, em 08 dez. 1981 e Carlos Jorge - Engenheiro da Companhia do Metrô-RJ, em 12 mar. 1982. 
afirmavam a impossibilidade de qualquer acordo para atuação conjunta entre a Companhia do Metrô-RJ e a RFFSA na resolução dos problemas de transportes para os subúrbios ${ }^{8}$; no entanto, esta mudança na definição dos trechos prioritários possibilitaria uma integração imediata com o sistema ferroviário nas estações Triagem e Estácio, ampliando assim a abrangência do Metrô, caso a integração fosse viabilizada.

A Cia do Metrô atualizou estudos de demanda e as previsões para o ano de 1975 e concluiu que o crescimento populacional da Zona Norte seria superior às previsões do Estudo de 1968, bem como o ritmo de crescimento da Zona Sul seria menos intenso, o que justificaria as mudanças de prioridade e a integração com o sistema ferroviário.

O Secretário de Planejamento do município, em 1978, declarou que o traçado em execução não era prioritário para a cidade e que, em sendo o Metrô um transporte de massa, o trecho inicial deveria ser a ligação centro-subúrbios ${ }^{9}$. Outros expressavam opiniões contrárias ao metrô de maneira geral, como o Conselho Estadual de Cultura que responsabilizava o Metrô através de moção aprovada por unanimidade - por obras que desfiguravam a paisagem do Rio de Janeiro. Um dos conselheiros afirmava que o tratamento urbanístico dado às áreas alteradas pelo Metrô durante as obras era de péssima qualidade, com a destruição de referências importantes do dia-a-dia do cidadão - segundo ele, o que é mais relevante na preservação de um patrimônio urbanístico - destacando como muito inadequada a solução urbanística dada à Cinelândia e em especial ao Largo da Carioca ${ }^{10}$.

\footnotetext{
${ }^{8}$ A ferrovia estava sucateada e só depois de um grave acidente em 1975, perto de Madureira, foi feita uma reestruturação administrativa na RFFSA, criando a $8^{\text {a }}$. Divisão e foram retomados os investimentos federais no setor, que só passaria à esfera estadual em 1994.

${ }^{9}$ Secretário de Planejamento acha que metrô deve começar com ligação Centro-subúrbio. Jornal do Brasil, 06 jul. 1978.

${ }^{10}$ Metrô poderá passar por Copacabana cortando morros. Jornal do Brasil, 24 nov. 1978.
} 
Outra discussão calorosa se deu entre técnicos das duas esferas de governo, municipal e estadual, sobre a futura extensão do Metrô para a Zona Sul que abandonava a idéia de chegar ao bairro do Leblon a partir da Tijuca, conforme o Estudo de Viabilidade - a maior parte em túnel -, passando à proposta de expansão da linha a partir do Botafogo, por Copacabana e Ipanema e daí chegando ao Leblon. A se obedecer o traçado inicial, uma segunda ligação Zona Norte-Zona Sul (Tijuca-Leblon), desta feita por transporte público de alta capacidade, seria construída, e certamente com custos de construção menores do que a futura extensão alternativamente proposta - especialmente com relação a despesas com desapropriações, mesmo considerando-se a abertura de túneis em rocha ${ }^{11}$. A extensão via Copacabana é a que veio a ser posteriormente construída, com economia de recursos em função da implantação da linha junto à encosta - redução de custos tanto em desapropriações quanto na construção, em função do método construtivo -, segundo vários artigos na grande imprensa do final do ano de 1978 e início de 1979.

Em 1978, durante a execução das obras civis dos trechos então prioritários (Tijuca-Botafogo e Estácio-Pavuna), a Companhia do Metrô-RJ, contando com recursos financeiros consideráveis, elaborou diversos estudos sobre expansão de rede prioritária, chegando mesmo à fase de projeto. O plano qüinqüenal ${ }^{12}$ da Companhia previa para o período $1979-1984$ as extensões da linha 1 do Botafogo a Copacabana (Praça Cardeal Arcoverde), linha 2 do Estácio ao Castelo, ambos os trechos subterrâneos, atravessando área de altíssima densidade e privilegiando a Zona Sul e a área central da cidade. As futuras extensões, com término da implantação em 1998, quando o sistema transportaria cerca de oito milhões de passageiros/dia em 93 km de linha seriam:

\footnotetext{
${ }^{11}$ Técnico sugere metrô pela encosta. Jornal do Brasil, 12 jun. 1977.

${ }^{12}$ COMPANHIA DO METRÔ (DP/DEPLAN/DIEST). Estudo Comparativo entre as Alternativas de Expansão da Rede Prioritária Básica. [1979]. 46 p.
} 
- subterrâneos: Estácio-Castelo, com 3,8 km e Botafogo-Leblon, com 6,5km;

- em superfície: Irajá-Recreio dos Bandeirantes, com 20 km, Maria da Graça-Ilha do Governador com 13 km e Niterói-Alcântara, em leito de ferrovia existente, com 13 km

- sob a baía: Castelo-Niterói, trecho em túnel submerso.

A Diretoria de Planejamento afirmava em 1978 a necessidade de se planejar e expandir o sistema de Metrô do Rio de Janeiro em função do grande número de viagens previsto. Comparava o sistema carioca com o sistema parisiense nos seguintes termos: em Paris, ao final da década de 1970, cerca de 10 milhões de pessoas realizavam 4,4 milhões de viagens/dia em 250 km de linha de metrô, e no Rio de Janeiro, essa proporção seria: cerca de 10 milhões de pessoas realizando 8 milhões de viagens/dia em 93 km de linha, caracterizando uma situação futura de maior densidade de deslocamentos no sistema do que a que ocorria em Paris. Imaginava-se que o Metrô em 1998 seria responsável por 42\% das viagens feitas no Grande Rio ${ }^{13}$.

Prevendo a valorização imobiliária que a implantação do sistema de metrô traria a algumas áreas da cidade, a Prefeitura do Município criou em 1977, através de decreto e no contexto do PUB-Plano Urbanístico Básico, a zona especial ZE-9, ao longo dos 37 km do traçado das linhas 1 e 2 da rede básica e Pré-Metrô - do Botafogo à Tijuca e do Estácio a Pavuna. A ZE-9 restringia as novas construções para evitar a descaracterização dos bairros, atendendo também às considerações dos técnicos do Metrô-RJ que previam uma saturação do próprio sistema com o adensamento junto às estações. Na época, foi suspensa a expedição de alvarás de construção para terrenos localizados na proximidade imediata do leito do Metrô, e mais tarde, liberadas num gabarito máximo de 10 andares. Os padrões de uso do solo, bem como as intervenções viárias nessa zona deveriam ser definidas através de um PEU - Projeto de

\footnotetext{
${ }^{13}$ Metrô amplia rede a partir de 1981 até cobrir 93 km. Jornal do Brasil, 12 jun. 1978.
} 
Estruturação Urbana específico. O licenciamento de edificações na ZE-9 ficou sob a responsabilidade da Secretaria de Planejamento, retirando essa atribuição do Departamento de Edificações, sendo cada caso estudado na sua particularidade, estabelecendo-se o critério de manutenção das densidades existentes como princípio orientador para a expedição de alvarás.

Ao Metrô-RJ interessava controlar o impacto da implantação do sistema na faixa lindeira às linhas e para isso contratou estudo que foi desenvolvido pelo IBAM, o Plano Impacto ${ }^{14}$, que revelou diferenças de uso, ocupação e ordenamento territorial em diferentes trechos do traçado, os quais deveriam ter tratamento particularizado com relação à legislação urbanística. O estudo indicou que haveria uma tendência à verticalização no bairro da Tijuca, bem como de superocupação dos terrenos no Botafogo e no Centro e para tanto, seria necessário controlar esses impactos, mantendo-se a densidade de ocupação do solo, através de medidas ordenadoras. Nos subúrbios, a diretriz deveria ser o aumento da ocupação residencial e de atividades produtivas, com o intuito de promover o desenvolvimento urbano, induzindo um adensamento junto aos centros de bairro, como Del Castilho, Irajá, Colégio e outros. Medidas específicas junto às estações de integração com o sistema rodoviário deveriam ser implantadas - Inhaúma, Acari e Pavuna.

Dois anos depois, foi criada uma Câmara Técnica ${ }^{15}$, presidida pela Secretaria de Planejamento e com representantes da Secretaria de Obras, Metrô-RJ, FUNDREM, IAB-RJ e de várias Associações de Moradores (Botafogo, Laranjeiras, Praça São Salvador, Catete e Flamengo), para debater os critérios urbanísticos a serem adotados para a ocupação das ZE-9, mais

\footnotetext{
${ }^{14}$ IBAM - Instituto Brasileiro de Administração Municipal. Plano Impacto. Rio de Janeiro, mimeo, [1978].

${ }^{15}$ Sobre as atividades da Câmara Técnica, foram feitas entrevistas com Franklin Scarton - FUNDREM, em 17 fev. 1982 e com Jó Resende - Presidente da FAMERJ - Federação das Associações de Moradores do Estado do Rio de Janeiro realizada em 04 mar. 1982.
} 
particularmente para a definição de gabaritos. Empresários do setor da construção, através do Sindicato da Indústria da Construção Civil se uniram para debater com o Prefeito Júlio Coutinho a liberação das áreas para utilização imediata e finalmente, a Câmara Técnica concluiu pela fixação de alturas variáveis nos diversos trechos, de dois a treze pavimentos, podendo as edificações ganhar mais altura quando isoladas das divisas. O Decreto Municipal de 21 de Julho de 1981 fixou os gabaritos da ZE-9 para o trecho Botafogo - Glória.

Ao longo de todo o traçado em execução, a Companhia do Metrô-RJ se adiantou ao empresariado privado no estoque de terras através das áreas remanescentes das desapropriações, feitas com fins de utilidade pública para a realização das obras. Cerca de $20 \%$ do total de áreas desapropriadas ${ }^{16}$ não foi utilizado para o sistema e passou a fazer parte do capital fixo da companhia.

O destino destas áreas foi alvo de um posicionamento diferenciado entre os diversos setores da sociedade interessados no seu aproveitamento. Os dirigentes da Companhia do Metrô-RJ consideravam legítima e no interesse público que fosse ela a usufruir a valorização imobiliária propiciada pela implantação do empreendimento, mesmo que os terrenos tivessem sido adquiridos através de decretos de desapropriação. Essa apropriação de valor se justificava ao se propor a redução dos pesados encargos da implantação do sistema através da utilização comercial dessas áreas, como ocorreu em vários empreendimentos semelhantes em outras cidades no mundo e timidamente em São Paulo. O Metrô-RJ chegou mesmo a projetar a construção e exploração de edifícios garagens e edifícios comerciais e de serviços nas saídas

\footnotetext{
${ }^{16}$ A dimensão da área remanescente das desapropriações só passou a ser conhecida após um trabalho detalhado de levantamento da situação das mesmas, de forma que, durante muitos anos discutiu-se genericamente sobre a utilização de terrenos, com exceção de algumas áreas de grandes dimensões na Zona Sul e na avenida Presidente Vargas. O número $40.000 \mathrm{~m} 2$ foi divulgado pela imprensa que posteriormente passou para $148.147 \mathrm{~m} 2$, sendo 53.332 m2 entre Botafogo e Tijuca, 21.185 m2 entre Estácio e Maria da Graça e 69.630 m2 entre Maria da Graça e Pavuna, segundo dados divulgados pela Cia do Metrô-RJ.
} 
de estação, bem como galerias comerciais. No Largo do Machado, enquanto se construía a estação, também foram iniciadas as fundações para um prédio de escritórios.

A Companhia do Metrô-RJ, prevendo conflitos, viabilizou uma estratégia de associação com o setor privado para a ocupação lucrativa dessas áreas supervalorizadas, propondo operações conjuntas, calando protestos que pudessem inviabilizar a idéia. No entanto, a partir de um posicionamento posterior da Companhia de que deveria se ater unicamente à venda dos terrenos e não à atividade de promoção imobiliária - lastreado em interpretações de cunho jurídico sobre a finalidade de constituição da Companhia, na utilização do instrumento da desapropriação para fins de utilidade pública e principalmente em função de suas dificuldades financeiras da Companhia - o empresariado muda de posição e passa a se opor à venda dos terrenos. Justifica sua posição pela obrigatoriedade de se adquirir esses remanescentes através de leilão e a grande probabilidade de que os ganhos no valor da terra com a componente localização junto ao eixo de transporte de massa seriam totalmente absorvidos pelo Metrô, segundo Mauro Magalhães, presidente da ADEMI ${ }^{17}$.

A idéia da Cia do Metrô-RJ para a destinação a ser dada aos terrenos remanescentes da desapropriação era: venda dos terrenos localizados nos locais mais valorizados ${ }^{18}$, em especial no Botafogo, Catete e Tijuca e disponibilização à CEHAB dos terrenos localizados junto à então Linha 2 e ao longo do Pré-Metrô para a construção de conjuntos habitacionais, mesmo aqueles de pequenas dimensões. Durante vários meses desenvolveu-se uma negociação do Metrô-RJ com o

\footnotetext{
${ }^{17}$ Entrevista com Mauro Magalhães - Deputado Estadual e ex-Presidente da ADEMI - Associação dos Dirigentes de Empresas do Mercado Imobiliário, realizada em 10 mar. 1982 e Revista Veja, 14 maio 1980 onde Magalhães declara: “[...] o metrô comprou terrenos com dinheiro da poupança nacional e agora quer vendê-los com fins lucrativos.”

${ }^{18}$ O Metrô-RJ apresentava uma posição com um certo grau de incoerência, pois ao mesmo tempo em que apoiava o critério de manutenção de densidades demográficas estáveis, de forma a não comprometer o sistema de transporte público, desejava uma valorização imobiliária que lhe permitisse ganhos com a venda dos terrenos bem localizados, o que significava aumento do potencial de ocupação dos mesmos.
} 
BNH e com o BNDE para uma operação triangular em que o Metrô, ao solicitar um aporte financeiro do BNDE para realização das obras, cedia ao BNH terrenos para a construção de moradias populares e este, por sua vez, saldava uma dívida com o BNDE diretamente ao MetrôRJ. Na prática, seria uma venda de terrenos ao BNH intermediada pelo BNDE.

Foram, no entanto, os moradores do entorno das estações o grupo social que mais se colocou contra a utilização das áreas desapropriadas pela Companhia e até mesmo contra a venda das mesmas $^{19}$. Através das diversas associações de moradores, a princípio as dos bairros de classe média na Zona Sul, politicamente mais atuantes, e em seguida na Tijuca e ao longo da linha do Pré-Metrô, a população se posicionou pelo uso comunitário destes terrenos, em especial para áreas de lazer e áreas verdes, tão escassas em muitos bairros, e eventualmente para a construção de terminais de transporte público. Assistiu-se então a uma luta fartamente divulgada pela imprensa $^{20}$, que durou muitos anos, sobre o destino desses terrenos, batalha em parte vencida pela população, que logrou constituir comissão pública ${ }^{21}$ para decidir sobre eles. Em julho de 1981, o Metrô cedeu terrenos no bairro de São Francisco Xavier, na Zona Norte para que a CEHAB construísse conjuntos habitacionais para funcionários do Metrô, com financiamento do BANERJ. Em novembro do mesmo ano, tramitou Projeto de Lei na Câmara de Vereadores obrigando a destinação dos remanescentes unicamente para lazer, cultura e saúde, que por vários motivos alegados - inconstitucionalidade e acordos políticos - não foi aprovado.

\footnotetext{
${ }^{19}$ Entrevista com Jó Resende - Presidente da FAMERJ - Federação das Associações de Moradores do Estado do Rio de Janeiro realizada em 04 mar. 1982.

${ }^{20}$ Os jornais cariocas de grande circulação, em especial O Globo e o Jornal do Brasil, iniciam a cobertura da questão dos terrenos remanescentes das desapropriações para as obras do Metrô em 1977, tendo sido analisados para este trabalho de pesquisa os posicionamentos dos diversos grupos sociais neles interessados, através de cerca de 50 artigos, a partir dessa data até o ano de 1982.

${ }^{21}$ A Comissão Especial criada pelo Decreto Estadual 3.944, constituída por representantes da Secretaria Estadual de Transportes, do BANERJ, do Metrô-RJ e da FUNDREM, definiu que parte dos terrenos remanescentes localizados na Zona Sul deveriam ser transformados em praças e áreas de lazer e parte deveria ser vendida. Na Zona Norte e ao longo do Pré-Metrô, a Comissão definiu a construção de conjuntos habitacionais e a implantação de áreas de lazer e pequenas praças.
} 
Até 1982 ainda não havia decisão firme sobre o destino desses terrenos, sendo que o Metrô argumentava que não poderia dispor deles para uso comunitário pois, como empresa, deveria responder pelo seu patrimônio, que incluía esses terrenos, a menos que fosse uma troca de terrenos com a Prefeitura. Os moradores exigiam que terrenos remanescentes de áreas desapropriadas deveriam ser usados pela comunidade , uma vez que eram bens públicos e que, mesmo que fossem vendidos, não aportariam ao Metrô-RJ uma quantidade de recursos significativa face ao valor do empreendimento, e que essa quantia pouco adiantaria para o andamento da construção.

No Metrô-SP, por seis anos, moradores do bairro de Santana lutaram nos tribunais, inconformados com a desapropriação de seus imóveis que não seriam utilizados pelo MetrôSP. Os antigos moradores não puderam reaver seus terrenos, pois a decisão do Supremo Tribunal Federal em 1977 deu ganho de causa ao Metrô-SP e as áreas passaram à jurisdição da EMURB, que acabou viabilizando dois edifícios de apartamentos e um de escritórios ${ }^{22}$.

Cabe ressaltar a importância que o episódio da luta pelas áreas remanescentes do Metrô-RJ teve para a criação e o fortalecimento das Associações de Moradores na cidade do Rio de Janeiro. Foram constituídas várias associações de moradores nos bairros atravessados pelas obras do Metrô, destacando-se as do Botafogo, Flamengo, Catete, Glória, Laranjeiras, Centro, Estácio, Afonso Pena, Saens Peña, Del Castilho, Maria da Graça, Acari, Pavuna, Anchieta e Coelho Neto. Constituiu-se também uma Federação das Associações de Moradores do Rio de Janeiro FAMERJ que passou a reforçar o conjunto de reivindicações em uma única voz, mais efetiva, e que posteriormente passou a atuar em outras áreas de interesse da população em geral.

\footnotetext{
${ }^{22}$ Grilagem Oficial. Revista Veja, 14 maio 1980. p. 56.
} 
Já em 1969, no início do segundo governo Chagas Freitas e em meio à crise financeira que abalou consideravelmente o Estado do Rio de Janeiro, a Companhia do Metrô avaliou a estratégia da gestão anterior, que abriu frentes de trabalho ao longo de toda a rede prioritária (37 km), como uma atitude pouco realista quanto às possibilidades de recursos e responsável pelo trecho tão curto em operação face aos recursos até então despendidos.

Mesmo criticando a política expansionista do governo anterior e apregoando contenção, novas recomendações da equipe de planejamento da Companhia foram divulgadas indicando a extensão do sistema através da ligação Tijuca-Leblon passando sob o maciço do Corcovado, chegando ao Jardim Botânico e desembocando na praça Antero de Quental ${ }^{23}$. Mais uma vez, o sistema de transporte rápido de massa seria ampliado de maneira a não levar em conta as dificuldades de deslocamento das camadas de menor poder aquisitivo e, desta vez, nem mesmo as possibilidades de atendimento de um enorme número de viagens geradas em Copacabana, o que atenderia uma extensa camada de classe média.

Pode-se afirmar que as discussões sobre traçado se deram exclusivamente no meio técnico e praticamente dentro da esfera governamental, sendo apenas noticiadas pela imprensa. Nem mesmo o empresariado do setor imobiliário foi consultado. Somente ocorreu alguma participação de entidades da sociedade civil e de moradores, através das recém-criadas associações, na discussão dos destinos das áreas do entorno das estações e ao longo das linhas congeladas no seu uso e ocupação através das ZE-9, ao terem assento na Câmara Técnica especialmente constituída, tendo, no entanto a decisão sobre o traçado já sido tomada. Posteriormente, discutiu-se a questão das áreas remanescentes e nesse caso, decisões foram

\footnotetext{
${ }^{23}$ Metrô começará obra para ligar Leblon à Tijuca em 1983. Jornal do Brasil, 14 abr. 1981.
} 
tomadas segundo a ótica da demanda, ao obstar o uso comercial desses terrenos e destinar parte deles para usos comunitários.

\subsection{A Evolução da Alocação de Recursos Financeiros}

O poder público perdeu a oportunidade de se associar ao capital privado na implantação do Metrô do Rio de Janeiro quando, em duas ocasiões, a Companhia Light and Power se adiantou em propor e participar do empreendimento. Na primeira, em 1929, o poder público faria as obras civis e a Light implantaria os equipamentos e operaria o sistema, em troca do recebimento integral da tarifa de uso. Na segunda ocasião, 1947, a mesma companhia que praticamente já monopolizava o sistema de transportes públicos da cidade, propunha a unificação dos transportes coletivos no Rio de Janeiro e apresentava estudo econômico que assegurava que, mediante um aumento nas passagens dos bondes em todas as linhas, haveria recursos suficientes para a implantação de uma linha de metrô. Com estes recursos adicionais, a Light se propunha a construir o novo sistema ${ }^{24}$. Em ambos os casos, tratava-se de uma ligação única, Zona Norte à Zona Sul, passando pelo centro e começando com o trecho Glória-Marquês de Sapucaí.

Todas as demais iniciativas apresentadas publicamente estabeleciam total responsabilidade do poder público sob duas formas alternativas:

1 - gerência do poder público, cujos fornecedores seriam empresas nacionais para projetos e obras civis, associações de empresas nacionais e estrangeiras para material rodante e empresas estrangeiras para os principais itens de operação de sistemas. A participação da indústria

\footnotetext{
${ }^{24}$ Informações obtidas a partir do Livro Histórico do Metrô, elaborado pela Companhia do Metropolitano do Rio de Janeiro, Rio de Janeiro, 1977.
} 
nacional no empreendimento seria dosada em diferentes proporções, de acordo com as condições da tecnologia nacional em cada área e

2 - compra pelo poder público de projetos e equipamentos estrangeiros numa operação do tipo “turn-key”, na qual as decisões sobre as características do empreendimento estaria nas mãos de um grupo estrangeiro especializado.

A posição adotada pelos Governos dos Estados da Guanabara e de São Paulo, quando finalmente decidiram construir os seus metrôs, baseou-se na primeira opção acima apresentada e conseqüentemente, foram constituídas as respectivas Companhias do Metropolitano que teriam responsabilidade integral pela construção, implantação, operação e gerência dos sistemas, subordinadas aos governos estaduais.

O Estudo de Viabilidade - 1968 para o Metrô-RJ previa um custo da ordem de US\$ 300 milhões para a implantação completa da linha prioritária $(18 \mathrm{~km})$ num período de 10 anos de obras, aproximadamente US\$ 16,6 milhões/km. Mesmo quando da aprovação do projeto e da decisão de se construir o Metrô-RJ, o Governo Estadual tinha consciência de sua incapacidade financeira de realizar a obra com recursos próprios e, em 1969, encaminhou relatório ao Governo Federal solicitando a participação financeira da União na execução das obras.

O Governador Negrão de Lima considerava que somente com o apoio do Governo Federal na forma de aval para empréstimos externos a obra poderia ser iniciada ${ }^{25}$. A Guanabara solicitou o aval do Governo Federal para as operações de crédito no exterior, num total de US\$ 201 milhões, e se propôs a contribuir com US\$ 99 milhões através de recursos próprios. Ao valor total, foram adicionados US\$ 75 milhões (25\% do investimento inicial) referentes ao custo da

\footnotetext{
${ }^{25}$ Notícia veiculada pelo Jornal O Globo, 02 mar. 1971.
} 
dívida externa, elevando o investimento total para US\$ 375 milhões, ou seja, US\$ 20,8 milhões/km. Na mesma época, a Companhia do Metrô-SP estimava para o custo de sua linha prioritária, que atravessava áreas menos complexas do que no Rio de Janeiro, um valor superior ao estimado para o Metrô-RJ, cerca de US\$ 29,5 milhões/km.

O Governo Federal, na Exposição de Motivos $n^{0} 106^{26}$, decidiu apoiar financeiramente a implantação dos dois sistemas de metrô oferecendo, no entanto, o seu aval para uma quantia de crédito externo inferior à requerida pelos dois governos estaduais. Dava garantias para US\$ 110 milhões e condicionava a participação dos governos locais na relação de dois dólares de recursos próprios para cada dólar de empréstimo estrangeiro. Nessa época, o Governo Federal punha em prática uma política de limitação dos empréstimos externos, de modo a manter os termos favoráveis de intercâmbio do país no período $1967-74^{27}$. O quadro do endividamento externo da companhia porém, mudaria radicalmente a partir dos anos 1974 e 1975 . Durante a primeira administração Chagas Freitas, o Governo do Estado da Guanabara não utilizou as facilidades do aval do Governo Federal em sua totalidade, tendo tomado no exterior, no período de 1970-75, metade dos recursos autorizados, ver Gráfico 2 - Empréstimos Externos 1969-80, não vinculados a fornecimento de material. Estima-se a participação do Governo Estadual, através de recursos próprios no período 1969-74 em cerca de US\$ 60 milhões. Esse valor rebaixaria a relação 2:1 (recursos próprios e empréstimo externo) constante nos termos da concessão de aval. Após negociações entre as duas esferas de governo, o Governo Federal concordou com a redução dessa relação para 1:1 para o trecho inicial ${ }^{28}$.

\footnotetext{
${ }^{26}$ BRASIL. Exposição de Motivos no 106, maio 1970.

${ }^{27}$ FURTADO, C. O Brasil Pós-Milagre. Rio de Janeiro: Ed. Paz e Terra, 1981.

${ }^{28}$ Jornal do Brasil, 29 dez. 1972: “São Paulo, maior e mais rico, teve condições de aceitar 1:2. A Guanabara só partiu quando o Governo Federal concordou em 1:1[...]”. A mesma matéria informa que a construção do metrô de Washington contou com um aporte financeiro considerável da esfera federal, na proporção de 2:1 com relação ao recurso local. Cabe observar que as obras do Metrô de São Paulo avançaram aceleradamente durante o período em que o Rio de Janeiro buscava alterar a relação de endividamento.
} 


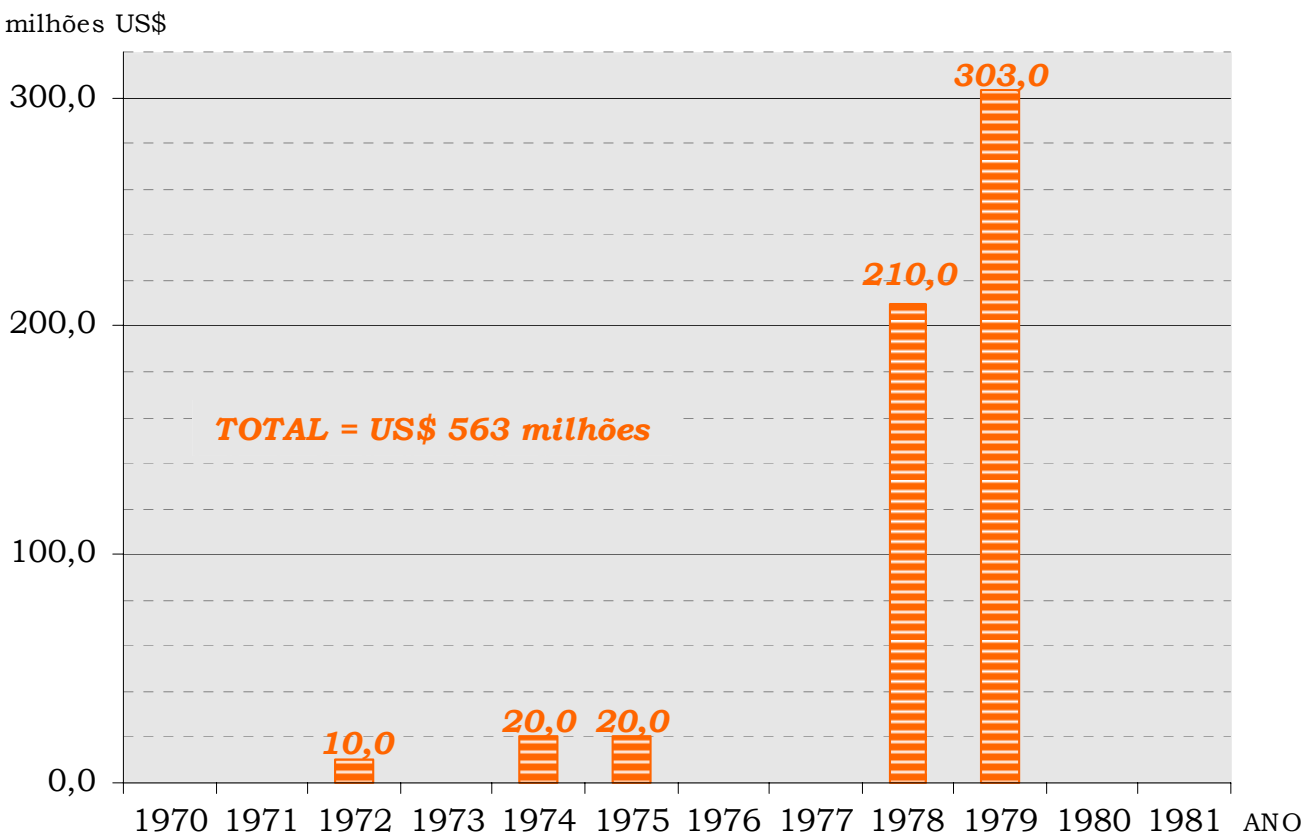

Gráfico 2 - Empréstimos Externos 1969-80, não vinculados a fornecimento de material

Através dos dados da Tabela 9 - Evolução da Situação Acionária da Companhia do MetrôRio de Janeiro 1969-80 através do Capital Integralizado (em Cr\$ constantes 1976) e Participação Acionária Percentual pode-se observar a evolução acionária da Companhia do Metrô desde sua criação até 1980. Até 1974, o Governo do Estado da Guanabara foi praticamente o único acionista ${ }^{29}$ e a partir de 1975, com a fusão político-administrativa dos dois estados, a situação se alterou completamente.

\footnotetext{
${ }^{29}$ Diversas companhias participam como acionárias nominais, dentre elas: CTC - Companhia de Transportes Coletivos do Estado do Rio de Janeiro, CETEL-RJ Companhia de Telefones do Rio de Janeiro, CEHAB Companhia Estadual de Habitação do Rio de Janeiro, CEDAE - Companhia Estadual de Águas e Esgotos. No entanto, o Governo do Estado detinha até 1974 uma participação superior a 99,9\%. Ver REVISTA DO METRÔ. Edição Comemorativa da Inauguração do Metrô do Rio de Janeiro, vol. 1, no. 1. Rio de Janeiro, mar. 1979. $72 \mathrm{p}$.
} 
Tabela 9 - Evolução da Situação Acionária da Companhia do Metrô-RJ 1969-1980 através do Capital Integralizado (em Cr\$ Constantes 1976) e Participação Acionária Percentual

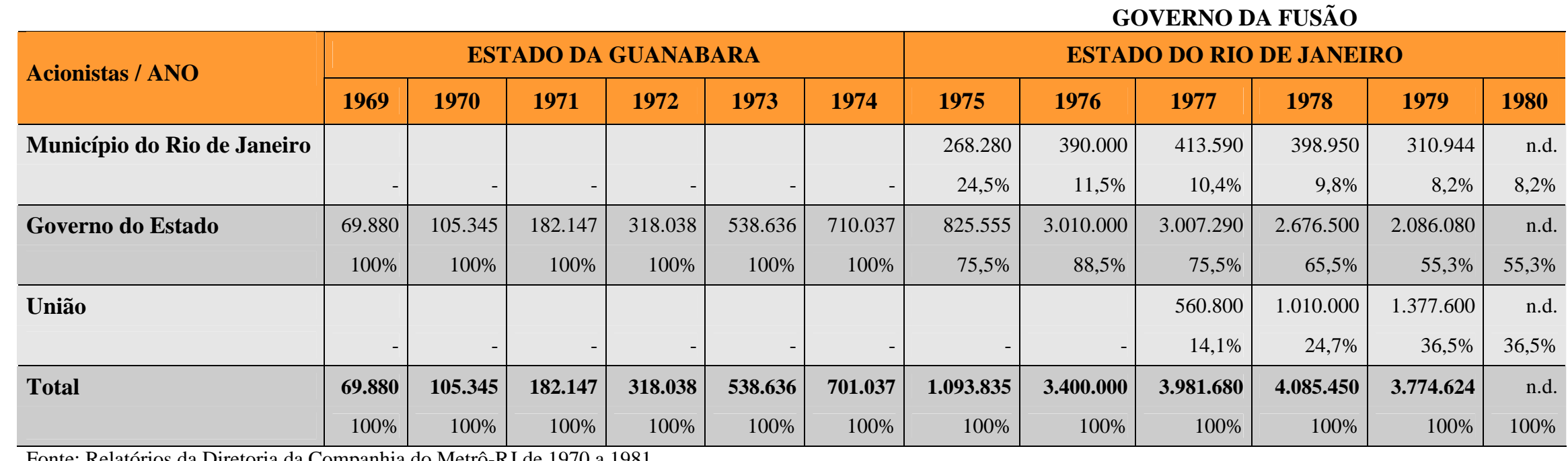

Fonte: Relatórios da Diretoria da Companhia do Metrô-RJ de 1970 a 1981

n.d.: Não temos informações sobre o valor absoluto 
O Município do Rio de Janeiro passou a acionista a partir de 1975, com uma participação relativa inicialmente alta, 24,5\%, porém decrescente, chegando a 8,2\% em 1980 . Em valor absoluto, sua participação se manteve em torno dos 400 milhões de cruzeiros, a preços de 1976, até 1978, não acompanhando, no entanto, a inflação no ano de 1979.

A partir de 1976, o Estado do Rio de Janeiro injetou recursos que quadruplicam o valor real de sua participação acionária, quando comparada com o valor mais alto atingido na administração anterior (em Cr\$ constantes de 1976). Uma parte desses recursos provém da União na forma de transferências a fundo perdido que, a partir de 1977, se consubstanciaram na participação acionária da EBTU na Companhia do Metrô ${ }^{30}$. Os valores da Tabela 9 ilustram a participação efetiva da União. De acordo com a Assessoria Direta do Ministério do Planejamento, a participação da União estava definida em Cr\$ 2 bilhões parcelados em cinco anos a partir de 1976 e sujeitos à correção anual, através da EBTU, em parcelas anuais de Cr\$ 400 milhões (em Cr\$ constantes 1976).

Desta forma, a participação acionária relativa na Companhia do Metrô se alterou para valores proporcionalmente crescentes do Governo Federal e decrescentes do Governo Estadual, atingindo em 1980 a proporção de 36,5\% da União, 55,3\% do Estado e 8,2\% do Município. A União se tornou assim proprietária de mais de um terço do Metrô-RJ. O mesmo não aconteceu em São Paulo que, em fins de 1974, concluía a linha prevista com os empréstimos autorizados e recursos próprios sem a interferência da União.

Foi a partir de 1975 que o quadro de endividamento da Companhia do Metrô-RJ se alterou substancialmente. Na Exposição de Motivos n ${ }^{\text {o. }} 179$ de 07/07/1975, o Governo Federal

\footnotetext{
${ }^{30}$ Entrevista com Haroldo Alves Costa, Assessoria Direta do Ministério do Planejamento no período em questão, no Rio de Janeiro, 11 mar. 1982.
} 
modificou sua posição quanto à tomada de empréstimos no exterior autorizando um limite global de US\$ 360 milhões sendo US\$ 50 milhões já obtidos, US\$ 90 milhões em operações ligadas a compra de material estrangeiro e US\$ 220 milhões em novos empréstimos não vinculados $^{31}$. O Gráfico 2 acima ilustra a tomada de empréstimos no exterior no valor de US\$ 210 milhões em 1977 e US\$ 303 milhões em 1978, conseguidos no mercado financeiro de Londres através de um "pool” de bancos internacionais a taxas de juros tipo Libor. Esses valores em muito ultrapassaram as resoluções das duas Exposições de Motivos do Governo Federal (1970 e 1975) e refletem a mudança de estratégia nacional quanto aos empréstimos no exterior. Segundo Celso Furtado, a partir de 1974, “[...] as empresas públicas e privadas foram incitadas a buscar no exterior para cumprir as metas de um plano de desenvolvimento excessivamente ambicioso, assumindo o Estado a responsabilidade cambial”32.

A Companhia do Metrô-RJ parece não ter fugido a essa regra. A sua Diretoria Financeira ${ }^{33}$ no período do Governo de Fusão teve posição contrária ao tipo de empréstimo tomado pela companhia no mercado londrino, advertindo serem operações com curtíssimo prazo de carência e taxas de juros recalculadas a cada seis meses. Trata-se de um dinheiro caro, justificável apenas para atividades de rápido desempenho, ou seja, quando resgatado num prazo bem curto, seis meses, por exemplo; o que não é o caso das grandes obras de infraestrutura. Outros tipos de empréstimo seriam mais adequados à empresa, ainda de acordo com o entrevistado: aqueles ligados a bancos de desenvolvimento com longos prazos de carência e

\footnotetext{
${ }^{31}$ Cabe observar que a Exposição de Motivos 179/1975 incluía a obrigatoriedade de integração do metrô com o sistema de subúrbio e ainda a inclusão de trecho junto à áreas povoadas por população de baixa renda e carentes de transporte de massa.

${ }^{32}$ FURTADO, C. O Brasil Pós-Milagre. Rio de Janeiro: Ed. Paz e Terra, 1981. p. 49.

${ }^{33}$ Entrevista com Bruno Costa Soares, Diretor Financeiro e Administrativo da Companhia do Metrô-RJ durante o Governo da Fusão, no Rio de Janeiro, em 18 fev. 1982.
} 
baixas taxas de juros e/ou aqueles vinculados à compra de equipamentos também com prazos e juros mais convenientes.

A tomada de recursos externos vinculados ao fornecimento de equipamentos, aqui chamada de crédito externo, atingiu no período 1969-80 o valor aproximado de US\$ 194 milhões principalmente concentrados no período 1976-78 como descreve o Gráfico 3 - Crédito Externo vinculado ao fornecimento de material, ou seja, cerca de uma terça parte do montante dos empréstimos não vinculados acima descritos ${ }^{34}$.

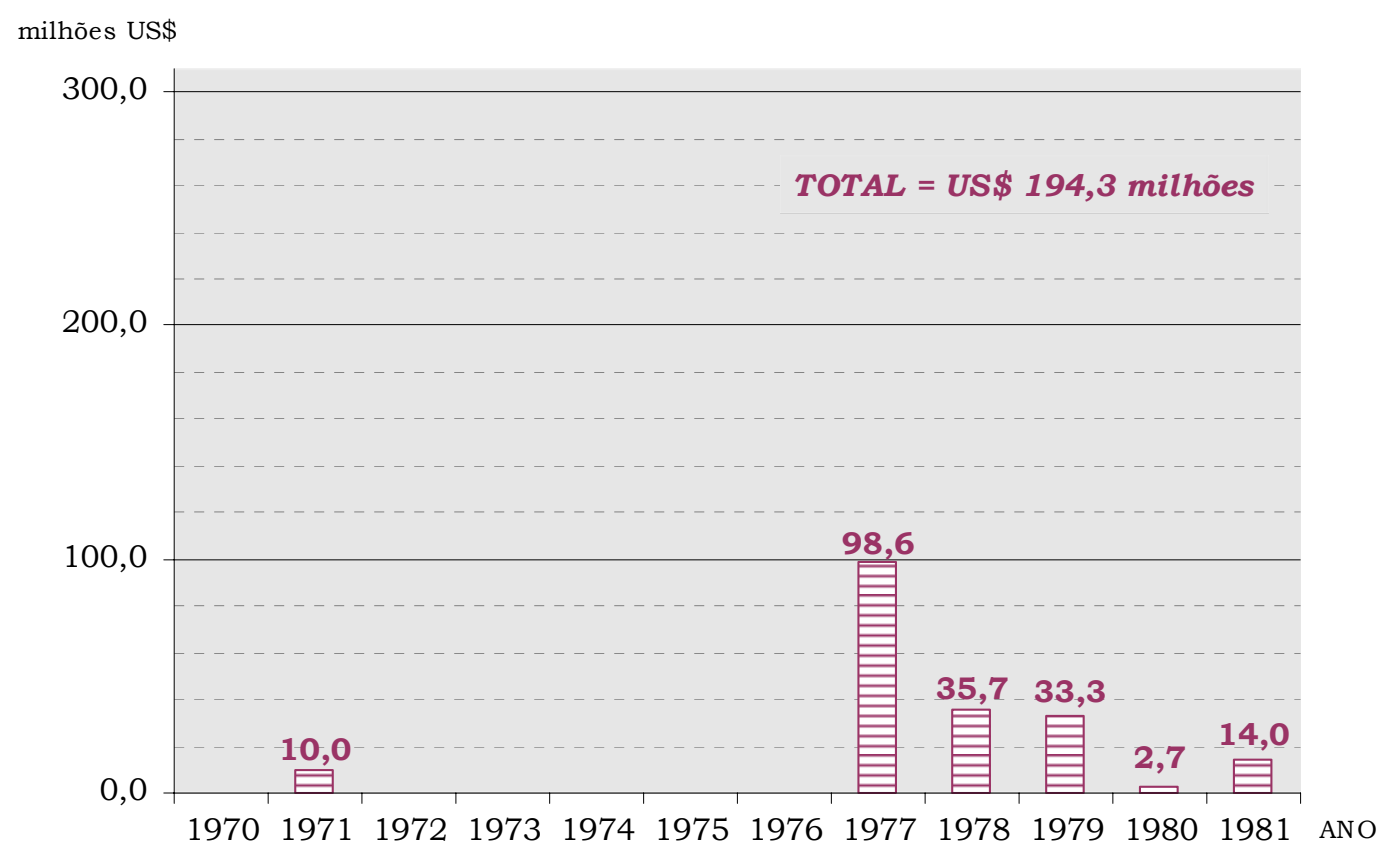

Gráfico 3 - Crédito Externo vinculado ao Fornecimento de Material

Dentro desse valor, através do Gráfico 4 - Crédito Externo vinculado ao fornecimento de material, por nacionalidade, 1969-80, percebe-se uma preferência pelos equipamentos e/ou condições de crédito de procedência francesa, $44,4 \%$ do total, seguidos de perto pelos americanos que participaram com 34,8\% do total. O restante foi dividido entre o crédito de 
procedência alemã, belga e inglesa, apresentando os grupos alemães uma posição claramente superior aos outros dois fornecedores de crédito e equipamentos, com 15,8\%. Grande parte do crédito francês proporcionava prazos de três a quatro anos para a primeira amortização, enquanto que os americanos e alemães restringiam os prazos para um ou dois anos ${ }^{35}$.

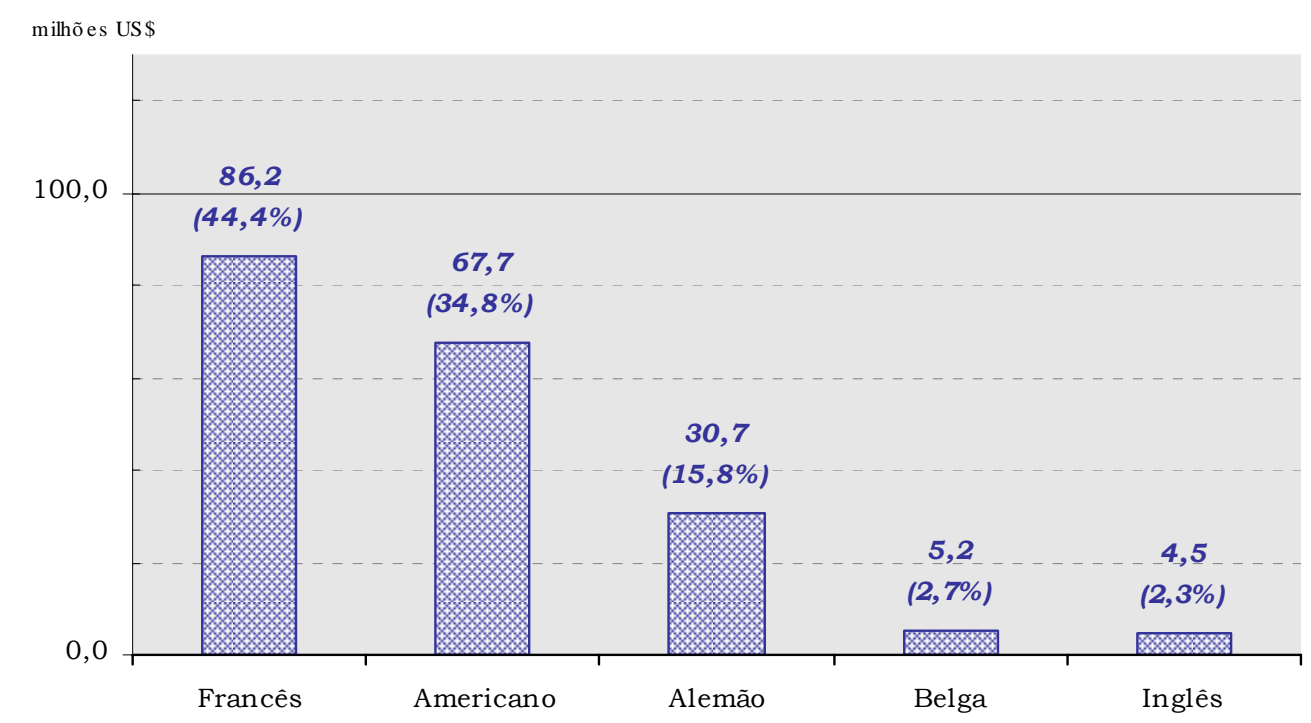

Gráfico 4 - Crédito Externo vinculado ao fornecimento de material, por nacionalidade, 1969-80

No que se refere ao mercado financeiro interno, os recursos captados também ocorreram a partir do Governo da Fusão, sendo que o maior empréstimo foi celebrado em 1980 junto ao BANERJ, no valor de US\$ 80 milhões, empréstimo não ligado à compra de material e US\$ 174 milhões em 1975, estes sim vinculados à compra de material. O Gráfico 5 - Empréstimos Internos não vinculados, 1969-80 apresenta o volume anual, no período de 1969-1980, tomados através do BANERJ e do Banco Safra num total de US\$ 108 milhões, a maior parte no período 1979-80, valores sem vínculo de compra de material. Os créditos vinculados ao fornecimento de material nacional, concedidos através da FINAME, somaram aproximadamente US\$ 307 milhões,

\footnotetext{
${ }^{34}$ Empréstimos vinculados ao fornecimento de material eram, em geral, mais favoráveis do que os empréstimos sem vínculo - prazos mais longos e taxas de juros menores.
} 
concentrados no período de 1975 a 1980, de acordo com o Gráfico 6 - Crédito Interno não vinculado a compra de equipamento nacional, $1969-80^{36}$.

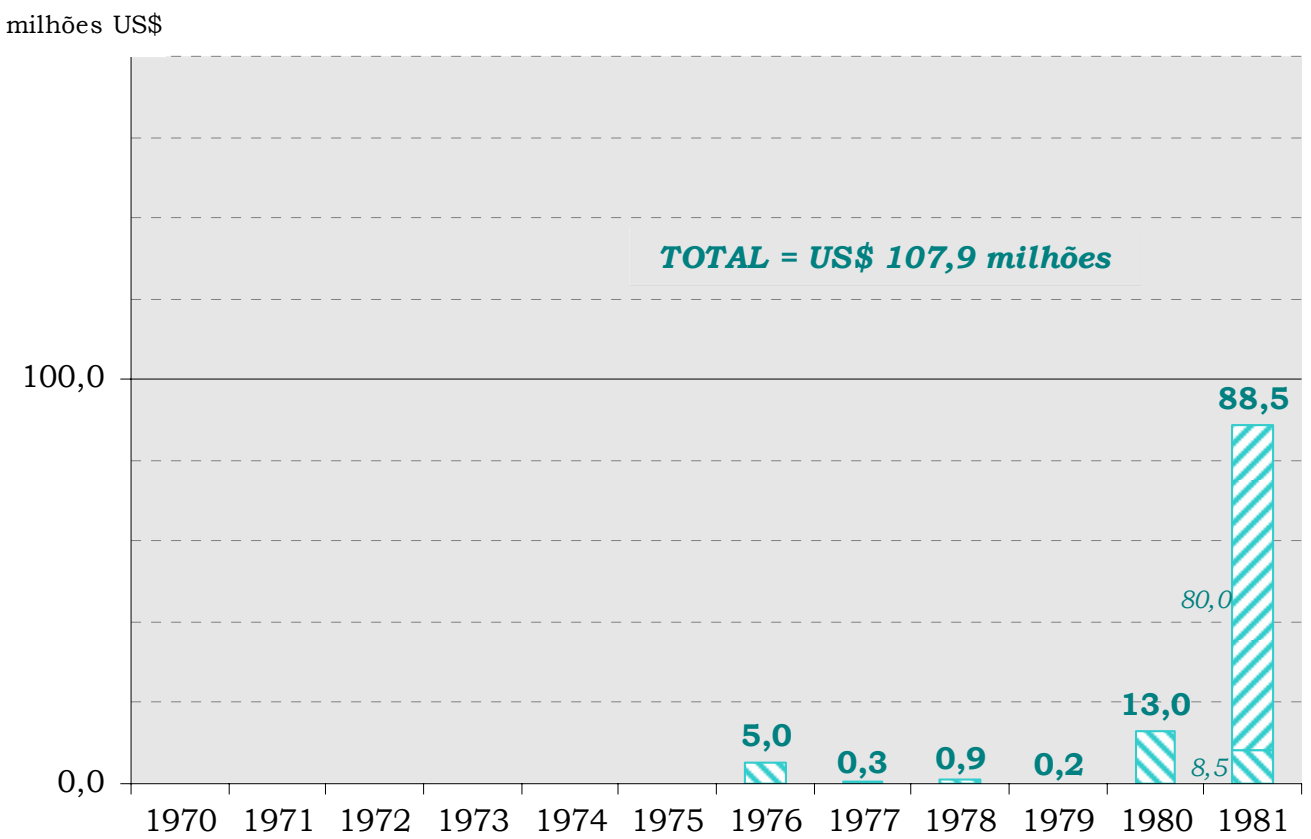

Gráfico 5 - Empréstimos Internos não vinculados, 1969-80

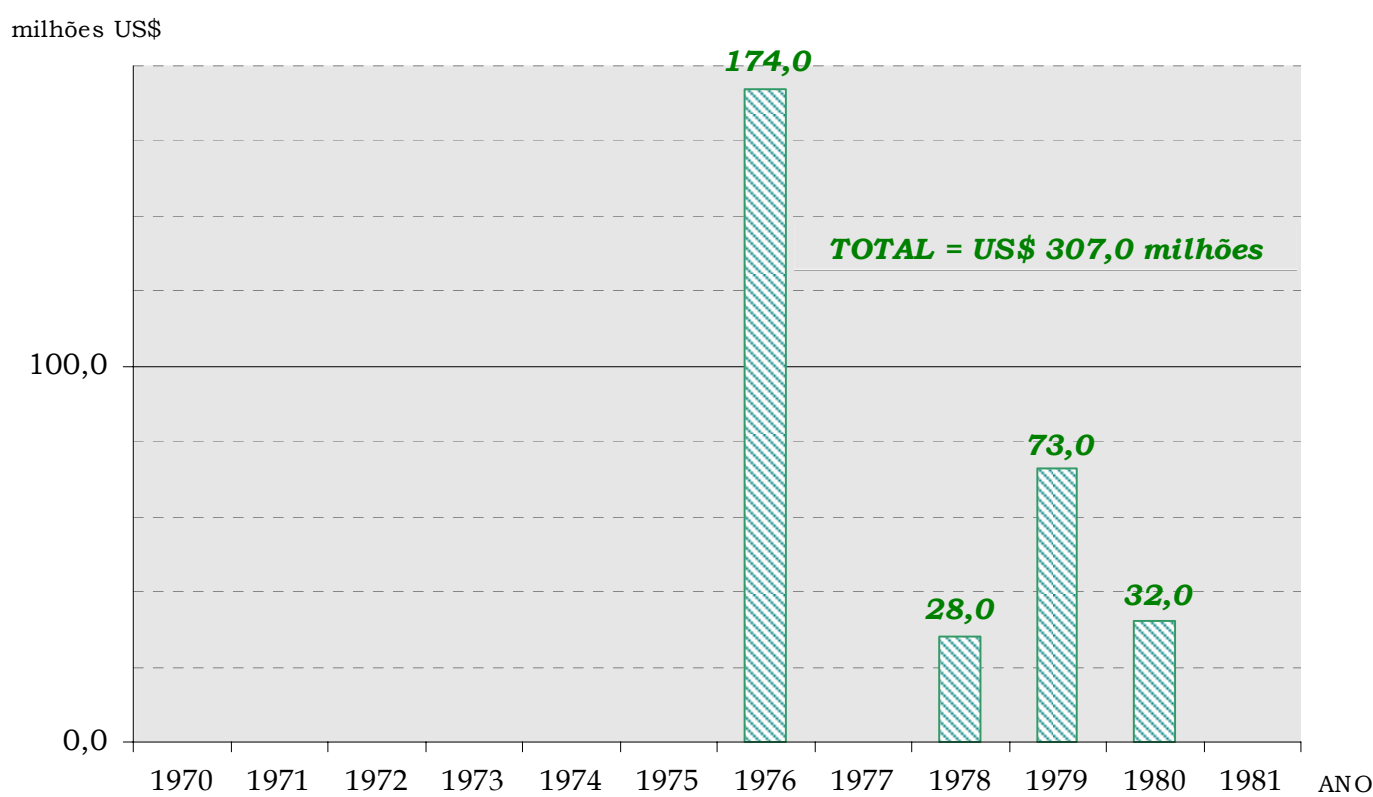

\footnotetext{
${ }^{35}$ As informações quanto aos recursos obtidos no exterior tem como fontes relatórios internos da Companhia do Metrô: Relação de Operações de Crédito Externo e a consulta direta às cópias dos contratos nos arquivos da empresa, efetuadas no Rio de Janeiro em Novembro e Dezembro 1981.

${ }^{36}$ As informações quanto aos recursos obtidos no mercado interno tem como fontes relatórios internos da Companhia do Metrô: Relação de Operações de Crédito Interno e a consulta direta às cópias dos contratos nos arquivos da empresa, efetuadas em Novembro e Dezembro de 1981, Rio de Janeiro.
} 


\section{Gráfico 6 - Crédito Interno não vinculado a compra de equipamento nacional, 1969-80}

A Companhia do Metrô-RJ tentou obter financiamento junto ao BNH através do subprograma FETRAN - Financiamento para Sistemas Ferroviários de Transportes Urbanos de Passageiros, mas considerou as condições de juros, $8 \%$, inadequadas, superiores a outras fontes nacionais.

Finalmente, o Gráfico 7 - Evolução dos Recursos captados no Mercado Financeiro Externo e Interno, 1969-80 sumariza a evolução dos empréstimos e créditos internos e externos para o período 1969-80, vinculados ou não à compra de material. A partir do total de recursos captados nos mercados externos e internos, US\$ 1.172 milhões, percebe-se uma concentração no período que se inicia com o Governo da Fusão. O auge do período foi alcançado no ano de 1978, quando foram negociados aproximadamente US\$ 409 milhões, a maior parte no mercado externo. Em termos de captação relativa de recursos, o mercado financeiro participou com 64,6\% (interno e externo) enquanto que os recursos vinculados ao fornecimento de equipamentos (interno e externo) cobriram os $35,4 \%$ restantes. Cerca de $48 \%$ do total dos empréstimos foram tomados no mercado financeiro de Londres, com as peculiaridades já discutidas. Ao se comparar os recursos obtidos para a compra de equipamentos, observa-se a participação do FINAME com US\$ 307 milhões destinados a equipamentos nacionais, contra US\$194 milhões para equipamentos estrangeiros.

As dotações orçamentárias, que somaram cerca de US\$ 315 milhões, na forma de ações da companhia, equivaleram a aproximadamente um terço dos recursos captados na forma de empréstimos, e finalmente a relação dos recursos totais nacionais e estrangeiros obedeceu, para o período 1969-1980, à proporção 1:1. Ou seja, valor equivalente da poupança nacional em recursos contratados no exterior. Os valores acima mencionados não cobrem o custo financeiro da obra, restringindo-se o total empregado, até 1980, a aproximadamente US\$ 
1.487 milhões $^{37}$. Admitindo-se $12,0 \mathrm{~km}$ de linha inaugurada e $24,8 \mathrm{~km}$ a $80 \%$ do seu término em média, pode-se ter uma idéia do custo aproximado por km de US\$ 46,5 milhões/km, sem contar o custo da dívida. Nesse valor estão associados os custos do Metrô e do Pré-Metrô.

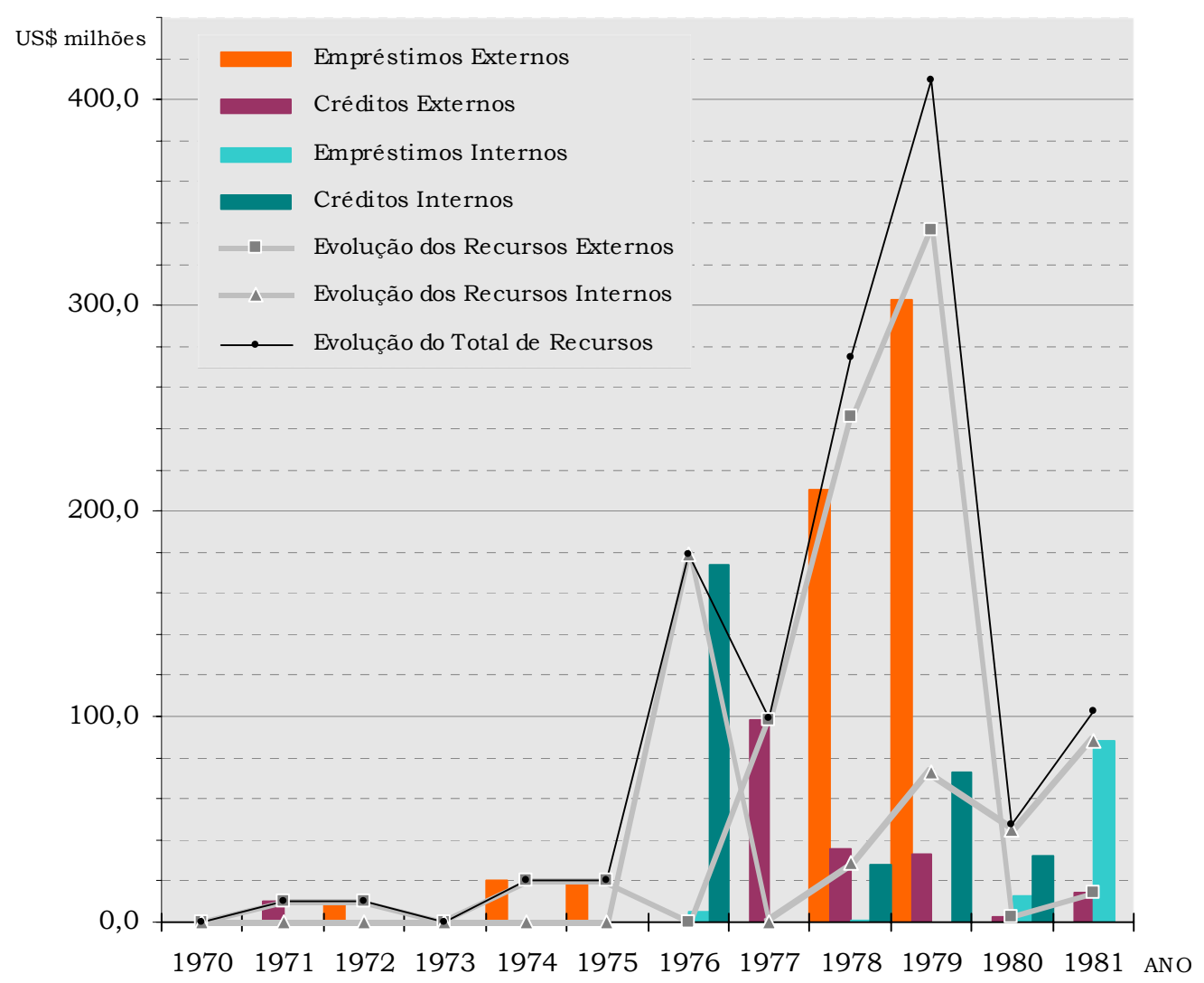

Gráfico 7 - Evolução dos Recursos captados no Mercado Financeiro Externo e Interno, 1969-80

A Tabela 10 - Aplicação dos Recursos da Companhia do Metrô-RJ por Categoria, 1974-1980, em \% do total das Aplicações de Capital sumariza as aplicações dos recursos da Companhia do Metrô-RJ nas principais atividades para o período 1974-81, de acordo com os relatórios anuais da diretoria, com informações não disponíveis para os exercícios de 1979 e 1980.

\footnotetext{
${ }^{37}$ Informações obtidas nos Relatórios de Diretoria da Companhia do Metrô e confirmadas nas entrevistas com Noel de Almeida, Presidente da Companhia do Metrô no período 1975-1980 e Bruno Costa Soares, Diretor Financeiro e Administrativo da empresa também no mesmo período, durante o Governo da Fusão, no Rio de Janeiro, em 21 jan. 1982 e 18 fev. 1982 respectivamente.
} 
Pode-se perceber que os compromissos financeiros (juros, amortizações, encargos e garantias contratuais) são um item importante na aplicação dos recursos, variando de 4,2\% a 17,6\% do total das aplicações no período 1974-78, o que significa gastos na cobertura da dívida equivalentes a até um quarto dos valores gastos em obras civis e equipamentos. Embora os dados para o período 1979-80 não estivessem disponíveis, pode-se observar, a partir do exame dos contratos de financiamento, que, no fim do Governo da Fusão, os gastos com compromissos financeiros começaram a crescer rapidamente, uma vez que os prazos de carência dos empréstimos contraídos começaram a vencer e a companhia deveria iniciar a amortização do principal. Conscientes desse endividamento crescente, a empresa tentou acelerar o ritmo das obras, com redução de alguns custos: reajustamento dos orçamentos das empreiteiras, custos de materiais, administração etc. Este período final da gestão Faria Lima coincidiu com um desaquecimento generalizado da economia nacional com correspondentes cortes de gastos públicos federais como medidas adotadas no combate à inflação. A Companhia do Metrô-RJ foi bastante afetada dentro dessa nova conjuntura econômica, assim como grande parte das companhias estatais.

Tabela 10 - Aplicação dos Recursos da Companhia do Metrô-RJ por Categoria, 19741980, em \% do total das Aplicações de Capital

\begin{tabular}{|c|c|c|c|c|c|c|c|c|c|c|c|}
\hline & 1974 & 1975 & \multicolumn{2}{|c|}{1976} & \multicolumn{2}{|c|}{1977} & \multicolumn{2}{|c|}{1978} & $1979 *$ & $1980 *$ & 1981 \\
\hline Administração & $4,8 \%$ & $5,0 \%$ & \multicolumn{2}{|r|}{$3,8 \%$} & \multicolumn{2}{|r|}{$5,9 \%$} & \multicolumn{2}{|r|}{$11,2 \%$} & & & $13,1 \%$ \\
\hline Desapropriações & $20,8 \%$ & $31,2 \%$ & \multicolumn{2}{|r|}{$27,4 \%$} & \multicolumn{2}{|r|}{$9,8 \%$} & \multicolumn{2}{|r|}{$4,9 \%$} & & & $0,1 \%$ \\
\hline Construção Civil & $52,6 \%$ & $33,6 \%$ & \multicolumn{2}{|r|}{$33,2 \%$} & & $4,7 \%$ & \multicolumn{2}{|r|}{$41,5 \%$} & & & $15,5 \%$ \\
\hline $\begin{array}{l}\text { Sist. Operacionais } \\
\text { e } \\
\text { Material Rodante }\end{array}$ & - & $16,2 \%$ & $\begin{array}{r}4,0 \% \\
11,3 \%\end{array}$ & $15,3 \%$ & $\begin{array}{l}16,8 \% \\
12,9 \%\end{array}$ & $29,7 \%$ & $\begin{array}{c}14,4 \% \\
6,9 \%\end{array}$ & $21,3 \%$ & & & $12,2 \%$ \\
\hline $\begin{array}{l}\text { Assessoria e } \\
\text { Consultoria }\end{array}$ & $4,8 \%$ & $2,7 \%$ & & $2,7 \%$ & & $2,7 \%$ & & $1,2 \%$ & & & $0,9 \%$ \\
\hline $\begin{array}{l}\text { Compromissos } \\
\text { Financeiros }\end{array}$ & $17,0 \%$ & $11,3 \%$ & & $17,6 \%$ & & $4,2 \%$ & & $11,6 \%$ & & & $58,2 \%$ \\
\hline Outros & - & - & & - & & - & & $8,3 \%$ & & & - \\
\hline Total & $100 \%$ & $100 \%$ & & $100 \%$ & & $100 \%$ & & $100 \%$ & & & $100 \%$ \\
\hline
\end{tabular}

Fonte: Relatórios da Diretoria da Companhia do Metrô-RJ - 1974 a 1981, Aplicação de Recursos. *Dados não disponíveis. 
O Governo Chagas Freitas herdou os pesados encargos das dívidas contraídas durante a gestão anterior sem que a receita de operação pudesse participar na amortização da dívida e com boa parte das obras ainda a executar. Em 1981, a companhia comprometeu 58,2\% dos seus recursos em compromissos financeiros, o que corresponde ao dobro do valor gasto em obras civis e equipamentos. O endividamento tendeu a se agravar com a paralisação das obras nesse período, o que contribuiu para aumentar os custos devido aos reajustes das empreiteiras, deterioração do material rodante, perda da garantia dos equipamentos, construção de depósito para estocagem, obras civis que deveriam ser refeitas, dentre outros aspectos. A companhia conseguiu saldar algumas dívidas mas restringiu seus investimentos a um mínimo.

Vários fatores colaboraram para a crítica situação financeira da Companhia do Metrô no início da gestão Chagas Freitas, de oposição ao Governo Federal. A União retirou seu apoio político e financeiro ao Metrô-RJ, antes irrestrito, esperando que o governo estadual em exercício, de oposição, arcasse com os compromissos para a continuidade das obras. No âmbito do Governo do Estado, a Companhia do Metrô perdeu sua autonomia quase plena para ficar inteiramente subordinada à Secretaria de Transportes, que por sua vez tinha outras prioridades de alocação de recursos. A implantação do metrô não recebeu a mesma atenção do novo governo. Ao mesmo tempo, venciam os compromissos da dívida; a falta de recursos atrasava as obras, e estas, por sua vez, demandavam mais recursos numa espiral deficitária alarmante.

Dentro desse quadro, o Governador praticamente declarou a insolvência da Companhia do Metrô ao afirmar que o Estado do Rio de Janeiro não tinha mais condições de se responsabilizar pela construção e operação do metrô e nem mesmo de honrar os compromissos financeiros relativos ao empreendimento e propôs a passagem da companhia 
para a tutela federal, através de sua anexação à RFFSA. O Governador chegou a pedir autorização na Assembléia Legislativa para que a doação pudesse se consumar. A União não aceitou a doação formal através do controle acionário, mas essa estratégia do Governo do Estado teve efeitos positivos pois forçou o Governo Federal a se pronunciar clara e publicamente sobre a sua responsabilidade no empreendimento, assumindo a sua paternidade. Como conseqüência, a União responsabilizou-se pela conclusão da rede prioritária de 32 km comprometendo-se a injetar a totalidade de recursos, a fundo perdido, para a continuação das obras. Ao Estado do Rio de Janeiro caberia assumir os compromissos da dívida contraída até essa época ${ }^{38}$. A administração estadual tentou ainda que parte da dívida a ela atribuída fosse paga pelo Governo Federal através de outra estratégia que não se mostrou eficaz. Deixando vencer os prazos para pagamento de uma parcela de US\$ 60 milhões, o Governo Federal foi obrigado a resgatá-la na sua condição de avalista. Entretanto, na liberação de verbas para as obras que se seguiu, a União resgatou a quantia adiantada.

Em 1981, a Companhia do Metrô calculava o custo por km do trecho em torno de US\$ 60 milhões caindo consideravelmente na linha 2 e no Pré-Metrô para um valor entre US\$ 10 a 15 milhões, segundo seu presidente Carlos Theophilo de Souza e Mello ${ }^{39}$. A maneira como se chegou a esse valor entretanto, não foi apresentado publicamente nem foi possível deduzir a partir do material disponibilizado pela empresa. Porém, acreditamos que o valor real seja ainda mais alto, visto que, mesmo com o trecho em operação, restavam, nessa data, quantias apreciáveis a serem pagas através dos compromissos financeiros que provavelmente não estão incluídos nesse valor.

\footnotetext{
${ }^{38}$ Declarações de Eliseu Resende na imprensa: Jornal do Brasil, 31 jan. 1980 e 08 maio 1980 e no O Globo, 10 ago. 1980.

${ }^{39}$ Folha de São Paulo, 02 ago. 1981, citação de Carlos Theóphilo de Souza e Mello sobre custo/km do MetrôRJ.
} 
Discutiu-se à época, com grande destaque na imprensa, o peso dos acabamentos das obras civis sobre o custo total do empreendimento. Muitos consideravam que os revestimentos em mármore nas estações encareciam a obra. A Companhia do Metrô-RJ refutava essas considerações com dois argumentos: primeiramente que o peso dos acabamentos sobre o custo total tinha pouquíssimo impacto e, em segundo lugar, que o alto valor do km era resultado de uma série de fatores, sendo os mais significativos: a demora no início da construção, as condições desfavoráveis do solo, o elevado número de desapropriações, o remanejamento das redes de serviços, as demolições e as reurbanizações ${ }^{40}$. A companhia também considerou a hipótese de utilização econômica da área não utilizada, excedente dos processos de desapropriação. Mas, a dimensão e localização dos terrenos resultantes não ensejaram empreendimentos que pudessem gerar renda significativa, bem como, sua utilização econômica pelo Metrô-RJ foi amplamente contestada, conforme já citado anteriormente.

Pode-se afirmar que quem efetivamente ditou as regras quanto à realização das obras, seu ritmo e opções técnicas foi o Governo Federal ao decidir sobre praticamente cada passo tomado pela Companhia do Metrô-RJ no que se refere aos recursos financeiros. Se inicialmente sua participação esteve restrita aos avais para endividamento externo, a partir do evento da Fusão, o Governo Federal investiu através de repasses para o governo estadual e em seguida através de fundo perdido, de forma que no início dos anos 1980 era seu principal investidor. Embora o Governo Federal tenha assumido parte considerável das responsabilidades financeiras, decisões tomadas exclusivamente na esfera federal vieram a colocar a Companhia do Metrô-RJ numa situação de endividamento junto ao mercado

\footnotetext{
${ }^{40}$ Várias reportagens no Jornal do Brasil no ano de 1976 destacando-se as dos dias 31 ago. e de 11 set.
} 
financeiro internacional que prejudicaram significativamente o seu desempenho, trazendo inclusive problemas de caixa para o estado.

\subsection{A Construção}

Durante o Governo Negrão de Lima, a CEPE-2 e posteriormente a Companhia do Metrô-RJ pouco realizaram em termos de obras civis. Após concluir o Estudo de Viabilidade em 1968, o consórcio teuto-brasileiro CCN-Hochtief-Deconsult foi contratado no mesmo ano para a execução dos Serviços Técnicos de Coordenação dos Projetos de Construção do primeiro trecho de Linha Prioritária, o que resultou num manual de especificações técnicas de construção civil de alta qualidade, utilizado até recentemente pela Companhia do Metrô-RJ ${ }^{41}$. Nesse período, foram assinados contratos para serviços de sondagem, topografia e projetos de engenharia e arquitetura. Iniciou-se também a concorrência pública para a escolha de empresas interessadas na construção da Linha Prioritária, que selecionou dois grupos: um, congregando as construtoras e projetistas ECISA, ECEL, ELC, Figueiredo Ferraz e Sondotécnica e o outro, CETENCO, ETEP e Brasconsult, também construtora e projetistas. O objeto da licitação eram os lotes 1 e 2 - trecho Central-Uruguaiana e lotes 5 e 6 - trecho Praça Paris-Glória, ficando o primeiro grupo com os lotes 1 e 2, de construção difícil envolvendo muitas desapropriações e remanejamentos de superfície e de subsolo, e o segundo grupo com os lotes 5 e 6, em área menos densa, por onde efetivamente se iniciaram as obras em junho de 1970. Ressalte-se que os preços apresentados pelo primeiro grupo de empresas era inferior ao segundo e ainda que o grupo da ECISA estava efetivamente interessado na execução dos

\footnotetext{
${ }^{41} \mathrm{O}$ estudo alemão indicava fontes de financiamento.
} 
quatro lotes licitados. No entanto, a Companhia do Metrô optou por dois grupos de empresas, mesmo contratando o segundo grupo por preço mais elevado ${ }^{42}$.

Técnicos do Metrô-RJ afirmavam que a indústria da construção civil nacional tinha condições de executar as obras civis e que fornecedores estrangeiros teriam espaço somente nas áreas ligadas a sistemas, equipamentos e material rodante ${ }^{43}$. No entanto, os franceses, consorciados à CETENCO, conseguiram entrar no mercado da construção civil através de CCI Compagnie des Constructions Internationales, que congregava quatro empresas francesas ${ }^{44}$, dividindo com o consórcio nacional liderado pela ECISA a totalidade das obras do trecho inicial. No entanto, negociações internas ao consórcio CETENCO - CCI levaram à dissolução do mesmo, sendo que as obras foram efetivamente realizadas apenas pela empresa nacional.

Na administração Chagas Freitas, a maior parte das atividades se concentrou também na área de projeto, sendo que as obras contratadas foram executadas em ritmo lento, evitando-se as atividades de desapropriação de imóveis que era considerado pela Companhia do Metrô o aspecto mais difícil do empreendimento. Em 1973, a empresa contratou, sem licitação pública, a SOFRETU - Sociétè Française d'Études et des Réalisations des Transports Urbains - empresa francesa de consultoria na área de equipamentos de transportes urbanos, ligada à RATP - Régie Autonome des Transports Urbains - especialmente para a elaboração

\footnotetext{
${ }^{42}$ Entrevista realizada em 15 fev. 1982 com eng. Waldner Paschoal, Diretor da ESUSA e que atuou como diretor do Consórcio ECISA-ECEL.

${ }^{43}$ Entrevista com engenheiros da Companhia do Metrô no período em questão: Carlos Jorge e com Cláudio
} Senna Frederico, Diretor de Operações, feitas no Rio de Janeiro respectivamente em 12 mar. 1982 e em 07 dez. 1981.

${ }^{44}$ Faziam parte da CCI - Compagnie des Constructions Internationales as seguintes empresas:

- $\quad$ GTM - Societé des Grands Travaux de Marseille;

- $\quad$ Entreprise Campeon Barnard;

- $\quad$ SGE - Societé Générale d’Entreprise e

- $\quad$ Societé Française d’Entreprise de Dragaje et Travaux Publique.

Fonte: Relação dos Contratos da Companhia do Metrô e consulta direta ao arquivo de contratos da Companhia do Metrô. 
de especificações para concorrências nacionais e estrangeiras para fornecimento de sistemas, material rodante e equipamento em geral.

A partir de 1975, com a Fusão, o volume de contratações aumentou, como mostra o Gráfico 8 - Evolução do número de contratos assinados pela Companhia do Metrô-RJ 1967-79 e a desapropriação da quase totalidade dos imóveis no trecho foi iniciada. Foi também durante o período do Governo da Fusão que a maior parte das obras civis foi executada e os equipamentos e sistemas foram definidos e encomendados. Com uma política de pagar o preço de mercado pelos imóveis na área lindeira ao eixo da linha do Metrô, a administração Noel de Almeida ${ }^{45}$ esperava reduzir o tempo necessário para as desapropriações, tarefa que, quando executado pela via judicial, é, em geral, morosa. As desapropriações foram feitas dentro de uma estratégia de compra e venda que, de acordo com funcionários da companhia teve um custo elevado, mas foi de rápida execução.

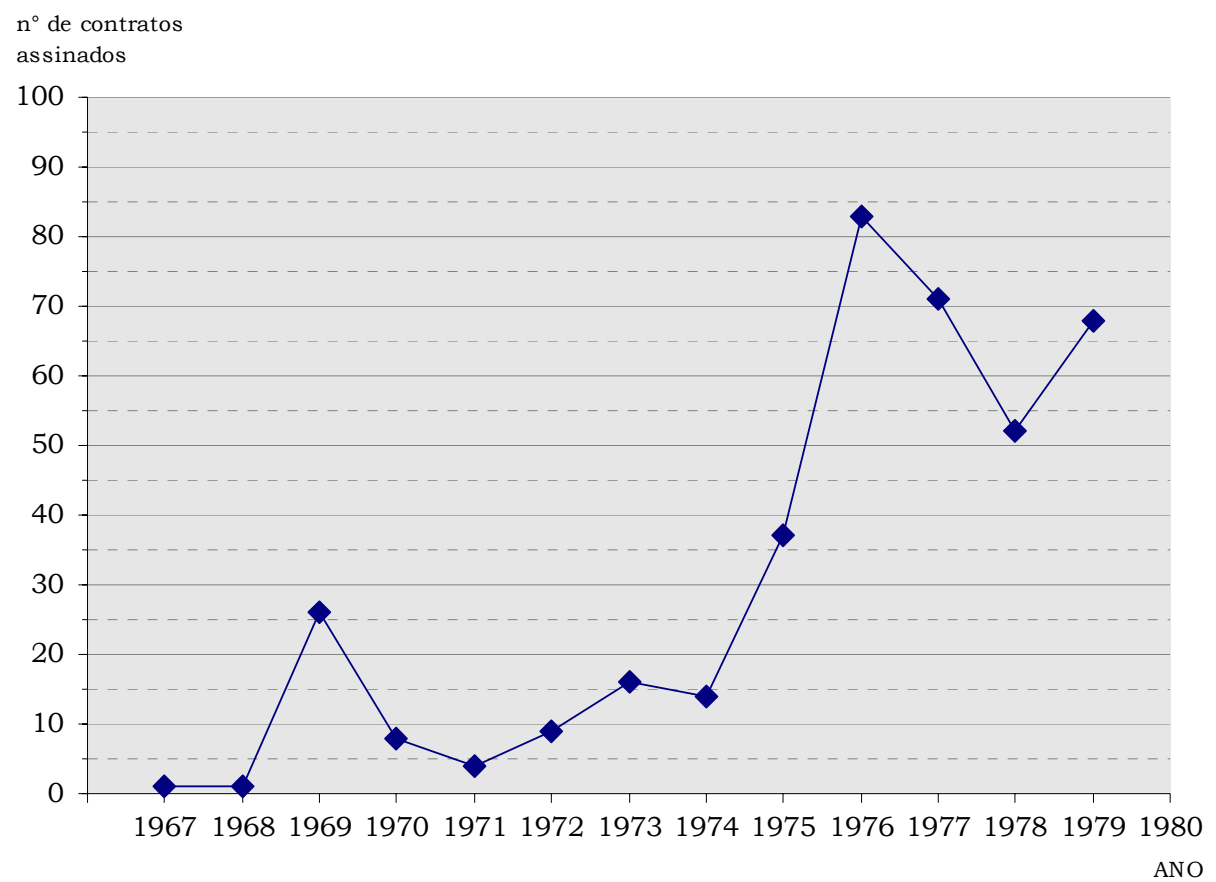

Gráfico 8 - Evolução do número de contratos assinados pela Companhia do Metrô-RJ 1967-79

\footnotetext{
${ }^{45}$ Noel de Almeida foi presidente da Companhia do Metrô do Rio de Janeiro no período de 1975 a 1980.
} 
Antes da Fusão, as empresas contratadas para a execução das poucas obras efetivamente iniciadas foram os consórcios ECISA-ECEL e CETENCO-CCI e, em seguida, na segunda licitação de obras, a Mendes Júnior recebeu o lote 21 - Cidade Nova e a ECISA-ECEL os lotes 3 - Uruguaiana, 4 - Largo da Carioca e o 7 - Catete e ainda o Centro de Manutenção e o trecho Triagem-Maria da Graça (em Pré-Metrô). Desta forma, no que se refere à construção civil propriamente dita, com a saída da CCI, as empresas nacionais conquistaram a totalidade do mercado. Com a Fusão, o ritmo se acelerou e as grandes empreiteiras nacionais passaram a se interessar pelas obras do Metrô-RJ, desvinculadas dos compromissos de construção de grandes obras no Rio de Janeiro, como a Ponte Rio-Niterói e o Aeroporto do Galeão e com disponibilidade para re-alocar um grande contingente de funcionários na região. A CBPO, a CETENCO (agora sozinha, desligada das companhias francesas), a Mendes Jr. e a Queiroz Galvão conseguiram através de concorrência pública vários lotes em seguida licitados. A ECISA era, na época, uma construtora carioca de porte médio a grande, sendo a vigésima sexta construtora nacional em 1972, de acordo com a revista VISÃO, Balanço Anual Quem é Quem. Não tinha, no entanto, experiência com grandes obras de infra-estrutura, tendo se consolidado na construção habitacional de grande porte em Brasília. As demais empreiteiras eram as tradicionais construtoras das grandes obras de infra-estrutura de âmbito nacional, que figuram, sistematicamente desde 1970 até aquela data, entre as 10 maiores empreiteiras de construção pesada ${ }^{46}$.

Cabe observar que as grandes construtoras não entraram na licitação para os primeiros lotes pois não acreditavam que a obra do Metrô do Rio de Janeiro fosse ocorrer. As indefinições técnicas eram muitas e os valores financeiros ofertados eram pouco expressivos. A CBPO, por

\footnotetext{
${ }^{46}$ Exceção feita à Queiroz Galvão, companhia de origem pernambucana que crescia vigorosamente, $29^{\mathrm{a}}$. colocada entre as maiores empresas de construção civil (em patrimônio líquido) em 1970, 11 a. em 1972, 15ª em 1976, $10^{\text {a. }}$ em 1979 e $8^{\text {a. }}$ em 1981. Fonte: Revista Visão, Balanço Anual, Quem é Quem, 1970, 1972, 1976 e Gazeta Mercantil, Balanço Anual 1979, 1981.
} 
exemplo, habilitou-se para apenas um lote, de forma a conseguir um atestado de construção de metrô, seu principal interesse, uma vez que financeiramente a obra não lhe parecia suficientemente rentável. Somente com a mudança de rumo que ocorreu com o Governo da Fusão, a presença de grandes empresas pôde ser observada, conforme Tabela 11 - Empresas contratadas para a construção do Metrô-RJ 1970 a 1979 abaixo.

Tabela 11 - Empresas Contratadas para a Construção do Metrô-RJ 1970 a 1979

\begin{tabular}{|c|c|c|c|}
\hline Licitação & Empresa & Lote & Trecho \\
\hline \multirow{4}{*}{ Primeira concorrência } & $\begin{array}{l}\text { Consórcio ECISA, ECEL, ELC, } \\
\text { Figueiredo Ferraz e Sondotécnica }\end{array}$ & Lote 1 & Central - Uruguaiana \\
\hline & $\begin{array}{l}\text { Consórcio ECISA, ECEL, ELC, } \\
\text { Figueiredo Ferraz e Sondotécnica }\end{array}$ & Lote 2 & Central - Uruguaiana \\
\hline & CETENCO* & Lote 5 & Cinelândia \\
\hline & CETENCO* & Lote 6 & Glória \\
\hline \multirow{6}{*}{ Segunda concorrência } & Consórcio ECISA - ECEL & Lote 3 & Uruguaiana \\
\hline & Consórcio ECISA - ECEL & Lote 4 & Largo da Carioca \\
\hline & Mendes Júnior & Lote 21 & Cidade Nova - Estácio \\
\hline & Consórcio ECISA-ECEL** & Lote 7 & Catete \\
\hline & Consórcio ECISA-ECEL** & Centro de Manutenção & Centro de Manutenção \\
\hline & Consórcio ECISA-ECEL** & Lote 32 & Triagem - Maria da Graça (pré-Metrô) \\
\hline \multirow{9}{*}{ Contratos Posteriores } & СBPO & Lote 8 & Morro Azul \\
\hline & CETENCO & Lote 9 & Botafogo \\
\hline & Mendes Júnior & Lote 22 & Afonso Pena - Engenho Velho \\
\hline & ECISA** & Lote 23 & Tijuca \\
\hline & Mendes Júnior - CENTENCO & Lote 30 & \\
\hline & CETENCO & Lote 31 & São Cristóvão - Maracanã \\
\hline & Queiróz Galvão & Lote 60 & $\begin{array}{l}\text { Pré-Metrô Del Castilho, Inhaúma, } \\
\text { Engenho da Rainha }\end{array}$ \\
\hline & ESUSA & Lote 61 & $\begin{array}{l}\text { Pré-Metrô Tomás Carvalho, Vicente } \\
\text { de Carvalho, Irajá, Colégio }\end{array}$ \\
\hline & Queiróz Galvão & Lote 62 & Pré-Metrô Coelho Neto, Acari, Pavuna \\
\hline
\end{tabular}

*Com os parceiros franceses através da CCI - Compagnie des Constructions Internationales.

**Construtoras que seriam posteriormente substituídas.

O esquema de pagamento da Companhia do Metrô às empreiteiras era regido por um sistema que definia o pagamento das medições das obras realizadas num prazo de 60 dias, extensível até 90 dias em casos excepcionais, sem correção monetária. Ao final do período da primeira administração da Fusão, quando os recursos começaram a diminuir, o prazo de 90 dias 
transformou-se no prazo corrente chegando, no entanto, em várias ocasiões, a mais de 180 dias para pagamento. Isso acontecia porque a liberação dos financiamentos obtidos e dos aportes de recursos federais não acompanhava o ritmo das obras, obrigando o capital de giro das empresas construtoras a, de certa forma, financiar as obras. Esta prática sacrificava as empreiteiras, sendo as menores, com menor suficiência financeira, mais prejudicadas do que as maiores.

Durante o ano de 1979, num dos primeiros períodos de crise, a ECISA, que mantinha 43\% do volume das obras, entrou em concordata e parou as obras em quatro dos lotes que construía: Catete, Tijuca, Centro de Manutenção e trecho Triagem-Maria da Graça (em Pré-Metrô). Inicialmente, a ECISA reduziu o ritmo de obras demitindo cerca de dois mil funcionários metade de seu contingente -, para em seguida paralisar todas as frentes de obras, que estavam em diferentes estágios de andamento. A empresa alegava não ter condições de suportar financeiramente os atrasos nos pagamentos das obras concluídas, que ultrapassavam os 90 dias contratuais, sendo obrigada a recorrer a empréstimos junto à rede bancária, além de reclamar de gastos internos crescentes relativos à nova política do Metrô, que estabelecia que a alimentação e alojamento dos trabalhadores deveriam estar a cargo da empreiteira, item não computado nos preços dos serviços ofertados. Nem para a ECISA e nem para a Companhia do Metrô era conveniente que a questão fosse resolvida judicialmente, em função dos tempos envolvidos nesse tipo de disputa, de forma que foi estabelecida uma negociação amigável, que resultou na solução em que a Companhia do Metrô realizaria as medições dos serviços realizados para serem pagos de imediato e a ECISA transferiria seus contratos para outras empresas, escolhidas pela Cia do Metrô, ocorrendo ajustes financeiros entre elas. Desta forma, as obras dos lotes paralisados não passariam por nova licitação pública, o que 
garantiria à Companhia do Metrô a manutenção de valores contratuais e um mínimo de tempo de paralisação das obras.

A Companhia do Metrô definiu dois critérios para a escolha das empresas que deveriam substituir a ECISA: primeiro o porte (de forma a assegurar capacidade financeira para suportar atrasos nos pagamentos superiores aos 90 dias contratuais) e segundo o fato de já disporem de contratos com o Metrô-RJ (para que sua inserção no ritmo das obras pudesse ser feito de maneira rápida, em especial quanto aos canteiros de obras já instalados, que deveriam estar localizados o mais próximo possível dos lotes a serem assumidos). Assim, o trecho referente às obras da Tijuca e o Centro de Manutenção ficaram sob a responsabilidade da Mendes Jr. ${ }^{47}$ e o trecho do pré-Metrô ficou com a Queiroz Galvão. As obras do Catete, já em estágio final de execução ficaram com a construtora Guarantã, que já construía as fundações de três prédios que a Companhia do Metrô pretendia executar sobre os acessos da Estação do Largo do Machado.

O pedido de concordata da ECISA foi uma resposta ao impasse gerado entre ela e a Companhia do Metrô quanto ao pagamento das dívidas; solução para abandonar as obras e para rescindir contratos que considerava inadequados e ainda congelar suas dívidas pelo período de dois anos. Rapidamente recuperada da crise financeira, um ano depois, a ECISA acionou judicialmente a Companhia do Metrô e seu presidente por danos morais resultantes das declarações à imprensa sobre a incapacidade da empreiteira em prosseguir nas obras ${ }^{48}$.

\footnotetext{
${ }^{47}$ Segundo informações obtidas através de entrevista com Cláudio Senna Frederico, Diretor de Operações da Companhia do Metrô-RJ, a Mendes Jr. realizou obras, pagando seus operários e insumos, mesmo sem receber do Metrô-RJ, praticamente financiando seus trechos de obra.

${ }^{48}$ A ECISA era em 1972 a $26^{\text {a. }}$ empreiteira do país, em patrimônio líquido, passando a $16^{\text {a. }}$ em 1975 , a $5^{\text {a. }}$ em 1978; a frente da Mendes Jr., passa a $6^{\text {a. }}$ em 1979. Mesmo depois da concordata, em 1980 mantém o $10^{\circ}$ lugar e em 1981 o $17^{\circ}$. Fonte: Revista Visão, Balanço Anual, Quem é Quem, 1970, 1972, 1976 e Gazeta Mercantil, Balanço Anual 1979, 1981.
} 
Cabe observar a posição da Companhia do Metrô-RJ quanto às empreiteiras locais, de porte médio, tradicionalmente as construtoras de infra-estrutura urbana do Rio de Janeiro. Na realidade, grande parte dessas empreiteiras foi sub-contratada pelas grandes construtoras, executando tarefas para as quais poderiam ter sido diretamente contratadas. Era de interesse dessas empresas, uma vez que reais executoras das obras, que pudessem se beneficiar do prestígio de construirem o Metrô-RJ para crescerem e se capacitarem para contratos de grande porte. A Companhia do Metrô-RJ, quando inquirida, alegava que a preferência pelas maiores empresas da construção do país se devia ao fato de não querer assumir a gerência de um grande número de empresas, o que lhe acarretaria maiores custos administrativos. Os editais das licitações que se seguiram passaram a apresentar requisitos que poderiam ser preenchidos apenas pelas grandes empresas, impossibilitando até mesmo consórcios que elevassem o capital ou o número de empregados ${ }^{49}$.

Quando a ECISA abandonou a construção dos lotes sob sua responsabilidade, as empreiteiras de porte médio, inicialmente representadas pela Associação dos Empreiteiros do Estado do Rio de Janeiro, tentaram se posicionar pressionando a Companhia do Metrô para que abrisse nova licitação, de maneira que estas empresas, associadas da maneira jurídica que mais conviesse ao $\mathrm{Metrô}^{50}$, pudessem participar diretamente das obras. A Companhia não foi sensível aos seus pleitos alegando que só aceitava a participação na construção do Metrô de construtoras de grande porte, com capacidade de enfrentamento adequado dos problemas financeiros que poderiam surgir, exemplificando o caso da ECISA. Os empreiteiros de porte médio, através de sua associação de classe, levaram seus protestos ao Governador lembrando

\footnotetext{
${ }^{49}$ Entrevista com o Presidente da Associação dos Empreiteiros do Estado do Rio de Janeiro, eng. Francismar Barbieri, no Rio de Janeiro em 08 mar. 1982.

${ }^{50}$ Propuseram associar-se, fundindo-se numa única empresa, cuja denominação seria Empresas Associadas do Rio de Janeiro Ltda, as cinco empresas - União, Cotepe, Carioca, Erco e Esusa -, que conseguiriam constituir um capital social superior ao valor das obras em questão.
} 
o Decreto Estadual no. 2.571 de proteção a empresas do estado, de 4 de Junho desse mesmo ano, 1979, que dizia que se estas apresentassem condições de igualdade com empresas de outros estados, teriam preferência na escolha ${ }^{51}$. No entanto, o Governador Chagas Freitas acabou por autorizar a transferência de contratos da forma proposta pela Companhia do Metrô. As únicas companhias construtoras do Rio de Janeiro que conseguiram ser contratadas diretamente pelo Metrô rompendo a chamada "barreira das grandes" foram a Itapema e a ECISA. A primeira porque conseguiu se especializar na relocação das redes de infra-estrutura começando como sub-empreiteira sendo, em seguida, contratada diretamente, mas unicamente para esses serviços. A ECISA que começou com pequenos contratos chegou a se colocar à frente de lotes de grandes dimensões, que constituíam 43\% do volume total de obras em andamento $^{52}$. A FIRJAN - Federação das Indústrias do Estado do Rio de Janeiro, entidade de grande influência, se posicionou na defesa dos interesses locais.

Não foi unicamente a ECISA que teve problemas financeiros durante a construção; a Construtora Beter, de origem paulista, também repassou parte de seus contratos, aqueles relativos aos serviços de acabamento das estações Morro Azul e Catete, para a CBPO e Mendes Jr., em maio de 1979. Também a ECEL, empresa que construía a Estação Largo da Carioca, pediu concordata no final do ano de 1979. Nessa mesma época, as empreiteiras que trabalhavam para o Metrô - ESUSA, Queiroz Galvão, Mendes Jr., CETENCO, CBPO, ECICEL e ECEL - decidiram, em conjunto, pressionar a companhia, através de nota publicada na imprensa, ameaçando paralisação das obras caso não fossem pagas as faturas pendentes a 150 e 180 dias.

\footnotetext{
${ }^{51}$ Nenhuma construtora de grande porte tinha, à época, sede no Estado do Rio de Janeiro.

52 Entrevista com Francismar Barbieri, Presidente da Associação dos Empreiteiros do Estado do Rio de Janeiro, no Rio de Janeiro em 08 mar. 1982; relação dos contratos da Companhia do Metrô-RJ e Livro Histórico do Metrô.
} 
Durante a administração Noel de Almeida, a Companhia do Metrô abriu frentes de trabalho em todos os $37 \mathrm{~km}$ considerados como trecho prioritário da rede, transformando a cidade num imenso canteiro de obras, causando distúrbios para a população ao longo do trajeto e para o trânsito de veículos em geral. A estratégia de abordagem de obras em toda sua extensão tinha a vantagem de torná-la irreversível em termos de traçado e implantação, caso não fosse concluída naquela administração. Entretanto, ela exigia um volume de recursos e uma capacidade administrativa que a companhia não conseguiu constituir num nível compatível.

No que se refere aos equipamentos - nacionais e estrangeiros -, os mesmos foram adquiridos em condições satisfatórias de crédito ${ }^{53}$, seja através do FINAME ou dos empréstimos externos vinculados à compra de material, o que de certa forma liberava a Companhia do Metrô-RJ para decidir quanto ao índice de nacionalização, dada a existência de crédito nacional. É possível que o custo dos equipamentos pudesse ter sido mais baixo se a opção tivesse sido por fornecimento do tipo "turn-key", mas ao decidir o tipo de equipamento e gerenciar sua aquisição e implantação, a Companhia proporcionava um ganho tecnológico para a indústria nacional. Os produtores de material rodante, por exemplo, afirmaram que esse segmento industrial conseguiu um ganho importante em desenvolvimento tecnológico com a produção dos carros para os Metrôs do Rio de Janeiro e de São Paulo, de tal forma que nas décadas seguintes, novas encomendas poderiam atingir índices de nacionalização superiores a $90 \%{ }^{54}$.

Os bancos franceses foram responsáveis pelo fornecimento de 44,4\% do total de crédito estrangeiro vinculado à aquisição de equipamento, de acordo com o Gráfico 4, de forma que

\footnotetext{
${ }^{53}$ Longos prazos de amortização e condições de juros favoráveis.

${ }^{54}$ Entrevista com José Carlos Couto Viana, Presidente da MAFERSA/SP em São Paulo em 01 fev. 1982. Entrevista com Mario Melo Torres, Diretor da Divisão de Equipamentos de Transporte da COBRASMA, em São Paulo, em 03 fev. 1982. Entrevista com Fábio F. Kowarick, Diretor Executivo da ABIFER, Associação Brasileira da Indústria Ferroviária, em São Paulo, em 03 fev 1982.
} 
as empresas francesas forneceram grande parte dos sistemas de alimentação de energia, de telecomunicações, comando centralizado, sinalização, piloto automático e bilhetagem dos 37 km em operação e em construção ${ }^{55}$.

A tecnologia francesa só não foi dominante no fornecimento do material rodante. Para o fornecimento de 210 carros para as linhas 1 e 2, foi contratado o consórcio de empresas brasileiras e americanas MAFERSA - Material Ferroviário S.A, Indústria Villares S.A., Westinghouse Eletric Corporation, Budd Company, os mesmos que já forneciam os carros para o Metrô-SP. Os fornecedores dos 60 carros para o Pré-Metrô consorciaram-se para a elaboração de estudos e projetos, produção e montagem; eram eles: COBRASMA S.A., Siemens S.A., Indústrias Elétricas Brown Boveri S.A., Siemens Aktiengesell Sehaft, La Brugeoise et Nivelles, Francorail - MTE Groupment d’Interêt Economique e outras com predominância de origem belga e alemã $^{56}$, com experiência em tecnologia de metrô leve.

As empresas brasileiras, com grande experiência de produção no setor ferroviário e com altos índices de ociosidade, participaram do fornecimento do material rodante em consórcio com as empresas estrangeiras e contaram com uma representação de classe, a ABIFER - Associação Brasileira da Indústria Ferroviária cujo principal objetivo era a proteção do mercado nacional. Esta sustentava que as contratações para a produção de carros para os metrôs, não apenas do Rio de Janeiro mas para outras capitais brasileiras, poderia ter tido um índice de nacionalização ainda maior do que aquele que foi efetivamente praticado. No caso dos metrôs

\footnotetext{
${ }^{55}$ Relação dos Contratos da Companhia do Metrô-RJ.

${ }^{56}$ De acordo com informações obtidas a partir de entrevista com Carlos Jorge, engenheiro da Companhia do Metrô-RJ, na primeira licitação relativa ao material rodante, a COBRASMA e consorciadas apresentaram preço praticamente duas vezes mais alto do que a MAFERSA. Já na segunda licitação, para os carros do Pré-Metrô, a COBRASMA ajustou seus preços de forma competitiva e ganhou a concorrência, repartindo o mercado. Isso, de certa forma, favoreceu a Companhia do Metrô-RJ que não ficou refém de um único grupo empresarial, o que se mostrou importante quando a Companhia atrasou pagamentos e a MAFERSA paralisou o fornecimento.
} 
de São Paulo e do Rio de Janeiro a MAFERSA conseguiu um índice de nacionalização no fornecimento pelo consórcio da ordem de 65 a 70\%, chegando no caso do Rio de Janeiro a $75 \%{ }^{57}$. A COBRASMA na produção dos carros para o Pré-Metrô chegou a um índice de nacionalização de 55 a 60\%, contando os 8 carros inteiramente produzidos na Bélgica e os demais 60 carros constantes da licitação ${ }^{58}$.

Praticamente não ocorreu nenhum apoio técnico por parte da Companhia do Metrô-SP, que acumulou experiência significativa e formou um corpo técnico de reconhecida competência, tendo a Companhia do Metrô-RJ optado seguidas vezes por consultores estrangeiros, franceses na maior parte das vezes, como apoio aos seus engenheiros ${ }^{59}$.

Um pequeno trecho da rede de metrô, pouco mais de 4 km, entrou em operação no final do Governo de Fusão, diminuindo consideravelmente os problemas que as obras causavam à população na área central. A administração Faria Lima conseguiu os dividendos políticos relativos ao início das obras civis de um trecho de grande extensão (37 km), deixando seu sucessor com a possibilidade física de concluir rapidamente o restante da linha prioritária e avançar as obras já adiantadas do Pré-Metrô. Deixou como herança, entretanto, o pagamento das dívidas que, a partir de 1979/80 tiveram seus prazos de carência esgotados, quando

\footnotetext{
${ }^{57}$ Segundo os dirigentes da MAFERSA, posteriormente, o índice de nacionalização na produção de carros da linha 2 - Leste/Oeste do Metrô-SP alcançou 95\%.

${ }^{58}$ De acordo com informações obtidas através de entrevista com o representante da MAFERSA, já citada, a decisão por um determinado fornecedor de material seguiu um rito mais complexo que os critérios de especificação técnica, qualidade e preço, e esteve diretamente atrelado às necessidades de equilíbrio da balança comercial do país. Isto se deu em função das possibilidades de vínculo de fornecimento de material com financiamento estrangeiro, não apenas para a parcela estrangeira do material como também para financiar parte da produção nacional. Nestes casos, os índices de nacionalização não puderam ser superiores a 55 ou $60 \%$, embora a indústria nacional tivesse condições de praticar um índice muito superior. O setor acreditava que seria sempre necessário manter uma participação estrangeira no fornecimento de material ferroviário, de forma que a indústria nacional pudesse se apropriar de novas tecnologias.
}

${ }^{59}$ Segundo informações obtidas através de entrevista com Fernando MacDowell - Diretor de Planejamento da Companhia do Metrô - entrevista em 08 dez. 1981. 
começaram a vencer as primeiras prestações. Os volumosos empréstimos tomados no mercado financeiro londrino em 1977 e 1978 foram renegociados, aumentando ainda mais o valor da dívida.

O Governador Chagas Freitas iniciou uma estratégia de contenção de gastos excluindo o Metrô das prioridades de sua gestão, somente dando prosseguimento às obras na medida em que recebia dotação do Governo Federal. Assim sendo, foram inauguradas as estações que estavam em fase de acabamento e sua atenção esteve dirigida ao término das obras de superfície, tentando devolver à população o mais rápido possível as áreas reurbanizadas, mesmo que a linha subterrânea ainda não estivesse em condições de operar. Na sua gestão, foi completado todo o trecho do Botafogo à Tijuca e o pequeno trecho de duas estações da linha 2. As obras do Pré-Metrô pouco prosseguiram nesse período.

Em seguida, o Governador Leonel Brizola, 1983-1987, contratou um diagnóstico compreensivo da situação dos transportes no estado, e a proposta feita para a região metropolitana pela equipe do arquiteto Jaime Lerner ${ }^{60}$ apresentou um enfoque distinto das administrações anteriores. Contrário às grandes obras que requerem investimentos volumosos e tentando aproveitar todas as possíveis soluções de transporte em superfície, a proposta considerava que a implantação do Metrô deveria se restringir ao que estava construído até então. Propunha alterações no esquema da Linha 1 e Linha 2 transformando-as em uma linha única funcionando em Y sem transbordos. Considerava que o sistema do Metrô poderia ser ampliado na direção de Copacabana, porém a longo prazo. Os recursos disponíveis deveriam ser utilizados para reorganizar as linhas de ônibus em sistemas de ônibus articulados ou até

\footnotetext{
${ }^{60}$ JAIME LERNER PLANEJAMENTO URBANO Sistema Integrado de Transportes - Versão Preliminar Estado do Rio de Janeiro. Projeto Rio Ano 2000, Governo Leonel Brizola. Rio de Janeiro: [s.n.], jan. 1984.
} 
bondes em corredores exclusivos que pudessem transportar grandes volumes de passageiros com uma quantia mínima de investimentos.

Finalmente é interessante observar os itens que mais consumiram os recursos empregados pela Companhia, a partir dos Relatórios de Diretoria da Companhia do Metrô-RJ e através da Tabela 10, já apresentada. Tanto durante o período em que ela contou com o maior volume de recursos, quanto nas épocas de pouco investimento, é a Construção Civil que mais consome recursos, variando de 33 a 52,6\% no período 1974-78. Desapropriações e a Compra e Instalação de Equipamentos e Material Rodante são os itens seguintes, mas distribuídos de maneira mais descontínua ao longo do período. Nas épocas de grandes gastos com Desapropriações - fase inicial de implantação - pouco se gastou com Equipamentos; enquanto que nas fases finais, com as Desapropriações já feitas, os gastos mais significativos foram com Equipamentos. A Construção Civil, entretanto, se mantém ao longo do tempo como a grande consumidora de recursos, sendo substituída pelos Encargos da Dívida que tenderam a se ampliar consideravelmente. 
CAPÍTULO 07 


\section{OS PRINCIPAIS AGENTES DA DECISÃO}

Este capítulo retoma o modelo gerado a partir da literatura consultada sobre os atores possivelmente presentes no processo de decisão em transportes urbanos apresentado no capítulo 2, bem como seus comportamentos, e discute a participação dos grandes grupos de interesse que fazem parte dos subsistemas produção, consumo e gestão vis-à-vis a reconstituição do processo decisório do Metrô do Rio de Janeiro apresentada nos capítulos 5 e 6, referentes às decisões de traçado, financiamento e implantação física. Em cada um desses grandes grupos estão inseridos grupos de interesses específicos ficando ainda evidenciados os interesses econômicos locais, os nacionais e estrangeiros. A forma de participação de cada grupo de interesse pode ser identificada através do material consultado - relatórios da Companhia do Metrô-RJ, jornais de grande circulação (Jornal do Brasil e O Globo), revistas especializadas (Revista da ADEMI, Revista da ANTP, Revista da Associação Comercial, Revista da Gazeta Mercantil, Revista do Metrô e outras citadas na bibliografia) - e um conjunto de entrevistas realizadas no início dos anos 1980 com agentes públicos, dirigentes da Cia do Metrô do Rio de Janeiro, representantes de entidades de classe, eleitos, representantes da sociedade organizada, da imprensa, dos setores secundário e terciário, da entidade produtora de estudos e projetos - SOFRETU, dos produtores de material ferroviario, do mercado imobiliario e da construção civil.

Relembrando, no subsistema produção dos transportes urbanos estão os produtores de estudos de transportes - escritórios de planejamento e de projeto, os financiadores dos empreendimentos (estudos e implantação) ligados aos sistemas de transportes, os produtores de infra-estrutura de transportes, produtores de material rodante e de equipamentos para o setor e os operadores do sistema de transportes a ser implantado. O interesse básico desse subsistema é a geração de 
oportunidades de trabalho que conduzam a um resultado financeiro que lhes satisfaça, assegurando uma participação no mercado em condições de competitividade que lhes pareçam aceitáveis, aí incluídas eventuais práticas protecionistas exercidas pelos governos.

No subsistema consumo dos transportes urbanos, estão os proprietários de terra e de imóveis em geral - grandes proprietários de terra, empresários/incorporadores do setor imobiliário e pequenos proprietários de imóveis, interessados na valorização de suas terras e de seus empreendimentos com um aumento de acessibilidade -; o setor secundário como um todo - responsável por toda a produção industrial urbana e interessado na acessibilidade de suas empresas de modo a facilitar a mobilização de sua força de trabalho -; o setor terciário como um todo - também interessado basicamente em aumentar a acessibilidade de suas empresas e na mobilização da população com poder de compra. A população em geral faz parte deste subsistema como principal consumidora dos transportes urbanos; também anseia aumentar sua mobilidade a custos mínimos, porém os anseios são fundamentalmente diferentes entre os grupos, na condição de motorizada ou cativa.

No subsistema gestão dos transportes urbanos estão as instituições públicas responsáveis pela concepção, implantação e gerência dos sistemas de transportes urbanos, representadas nas diversas esferas de governo através da burocracia técnica e dos principais líderes dessas instituições.

Como se posicionaram os principais grupos de interesse acima elencados na concepção e implantação do sistema de Metrô do Rio de Janeiro? 


\subsection{Os Produtores dos Transportes Urbanos}

Pode-se observar que no setor dos transportes urbanos, em especial no caso do Metrô-RJ, várias companhias estrangeiras procuraram entrar no mercado e até influir na geração de uma demanda pelos seus serviços durante este último século.

No início do século XX, as companhias inglesas propuseram para o Rio de Janeiro um conjunto de ações para a instalação de um sistema de Metrô; postura que tiveram em outras cidades, como São Paulo e Buenos Aires. Essas ações compreendiam estudos, construção, fornecimento de equipamento e sua instalação, gerenciamento de obra e operação do sistema, propondo uma tecnologia que não fazia parte das competências nacionais, quando o país apresentava uma capacidade produtiva nesse setor ainda muito incipiente. As tentativas estrangeiras de aproximação prosseguiram, na forma de ofertas que abrangiam todos os passos para a implantação do sistema e independentes de parceiros nacionais, até o crescimento sustentado da indústria no Brasil a partir da segunda metade do século XX.

Com o desenvolvimento do processo de industrialização nacional, em especial da indústria da construção civil, impulsionada com a construção de Brasília, grupos nacionais passaram a ter boa parte da competência técnica necessária para a construção de infra-estrutura pesada, destacandose a construção de pontes, túneis, barragens para aproveitamento hidrelétrico e estradas em geral. A produção de materiais e equipamentos e a prestação de serviços no setor também passaram por uma fase de desenvolvimento, de forma que as oportunidades de entrada de empresas estrangeiras nessas atividades foram se reduzindo a partir da segunda metade do século passado. 
Na década de 1960, quando a idéia de implantação de um Metrô no Rio de Janeiro começou a tomar corpo (com o aumento do fluxo de viagens e de veículos e com a exaustão dos espaços viários para o tráfego na cidade), o Governo da Guanabara iniciou o processo de licitação internacional para a elaboração dos estudos de viabilidade e apresentaram-se para essa seleção grupos de especialistas franceses, americanos e alemães; estes últimos já em consórcio com uma grande empresa brasileira de construção civil. Embora ainda interessadas em todos os aspectos da implantação do empreendimento, as companhias estrangeiras foram obrigadas a ceder espaço para as empresas nacionais, maior ou menor, em função da capacidade técnica local.

\section{Produtores de estudos e de transportes - escritórios de planejamento e de projeto}

Os estudos iniciais para a implantação de um Metrô no Rio de Janeiro, feitos pela Companhia Light, não tiveram prosseguimento. Em seguida, pode-se observar a importância significativa da tecnologia francesa junto aos engenheiros ferroviários brasileiros, com a presença de vários engenheiros franceses e da SGTE - Societé Génèrale de Traction et Exploitation (esta apresentou projeto que chegou a ser aprovado pela administração) nos primeiros anos da década de 1950 . O governador Carlos Lacerda chegou a viajar para a França na busca de crédito para a construção do Metrô no início dos anos 1960, embora, como vimos, não estivesse efetivamente interessado.

A maior parte das comissões ou grupos de estudos oficiais defendia soluções clássicas subterrâneas, atitude previsível em função da grande penetração da companhia francesa SGTE na administração pública e das missões francesas, compostas por técnicos e empresários, que nas décadas de 1950 e 1960 aconselharam as comissões técnicas brasileiras. Ingleses, alemães e 
japoneses tentaram intervir com soluções de superfície ou elevadas, do tipo Alweg ou monotrilho, respondendo assim a traçados menos convencionais.

Como já vimos, a concorrência internacional realizada em 1968 teve por objetivo estudar a viabilidade de um sistema de transporte rápido - Metrô - para o Rio de Janeiro, definindo características e traçado, volume de investimentos e um plano de financiamento, com indicações das principais fontes domésticas e externas. O edital do certame definia que, no planejamento do sistema operacional, o estudo deveria aconselhar, na medida do possível, produtos nacionais para a instalação e manutenção do sistema, assim como existia uma orientação de política pública de que, nos processos para a contratação das obras civis de empreendimentos públicos, tivessem preferência empresas brasileiras. Foi selecionado o Consórcio CCN - Hochtief - Deconsult para a elaboração do Estudo de Viabilidade do Metrô do Rio de Janeiro, composto por empresa nacional de construção civil (CCN - Companhia Construtora Nacional) e um grupo de projetistas de origem alemã que sub-contrataram várias empresas e consultores brasileiros e que já estavam presentes no Metrô de São Paulo.

O grupo vencedor elaborou o estudo e certamente almejava uma abertura do mercado para equipamentos de mesma origem, bem como alguma possibilidade de entrar nos contratos da

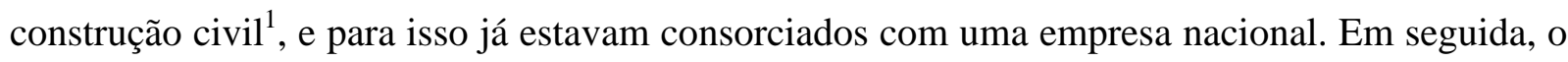
mesmo grupo foi contratado para as especificações técnicas de obras. Esse trabalho de especificações elaborado pelos engenheiros alemães foi considerado exemplar e acabou sendo

\footnotetext{
${ }^{1}$ Conforme informações obtidas através de entrevista em 18 fev. 1982 com Bruno Costa Soares - Diretor Financeiro e Administrativo da Companhia do Metrô-RJ durante o Governo da Fusão e em 08 dez. 1981 com Leandro

Petronilho - Diretor de Engenharia da Cia do Metrô.
} 
integralmente utilizado pela Companhia do Metrô-RJ como manual para as licitações para contratação das obras civis ${ }^{2}$; os quais, no entanto, não conseguiram trabalhar nas obras.

O fato dos alemães terem vencido a concorrência frustrou os interesses do grupo técnico de origem francesa, pois foram estes os que mais investiram em conselhos e missões que periodicamente visitaram o Brasil durante pelo menos uma década, anteriormente à elaboração do Estudo de Viabilidade. Os representantes da SOFRETU - Societé Française d'Études et des Réalisations des Transports Urbains, sociedade especializada em estudos, planos e projetos de transportes eram os contatos das empresas francesas junto aos técnicos do Metrô - $\mathrm{RJ}^{3}$. Embora a recomendação geral para todos os certames licitatórios fosse para que preferencialmente fossem contratadas empresas brasileiras para construção e para fornecimento de materiais, na primeira concorrência para execução de obras civis, grupos franceses do setor da construção civil se consorciaram com a brasileira CETENCO e conseguiram vencer metade dos lotes licitados, ficando a outra metade com empresas locais.

No entanto, negociações internas ao consórcio CETENCO - CCI (Compagnie des Constructions Internationales), que congregava quatro empresas francesas GTM - Societé des Grands Travaux de Marseille; Entreprise Campeon Barnard; SGE - Societé Générale d’Entreprise e Societé

\footnotetext{
${ }^{2}$ Esse trabalho foi utilizado como base técnica para os estudos sobre transportes realizados pelo Grupo de Trabalho encarregado do desenho institucional da fusão dos dois estados, no que se refere aos transportes urbanos.

${ }^{3}$ Informações obtidas em entrevistas na sede da SOFRETU - Societé Française d'Études et des Réalisations des Transports Urbains, na França, em 02 jul. 1981 com Young - responsável no período 1973 a 1976 pela filial da empresa no Rio de Janeiro - e em 21 maio 1981 com Arras - Presidente da empresa. A SOFRETU teve uma presença de grande abrangência no Brasil; além do Metrô-RJ, esteve na modernização de trens entre São Paulo e Rio de Janeiro, no setor de trolleybus em São Paulo e ônibus em Recife, nos corredores exclusivos para ônibus e tarifação em Curitiba e ainda alguns trabalhos em Salvador. Na América Latina destacam-se ações na Argentina, Venezuela, Colômbia e no Metrô de Santiago no Chile.
} 
Française d'Entreprise de Dragaje et Travaux Publique, levaram à dissolução do consórcio, sendo que as obras foram efetivamente realizadas apenas pela empresa nacional.

Os grupos franceses rapidamente perceberam a redução de oportunidades para a entrada de companhias estrangeiras no mercado da construção civil e passaram a investir na área de equipamentos e sistema em geral, uma vez que a indústria nacional não teria condições de fornecimento nesse segmento, propondo consultoria na elaboração de especificações técnicas e normas para concorrências. Certos de que, para tanto, o produto seria necessariamente estrangeiro, tratava-se de especificar elementos produzidos a partir de tecnologia de domínio francês. Esperavam, através dessa conduta, ter mais chance nas concorrências nesse segmento. Sem passar por nenhum processo licitatório, a SOFRETU, empresa francesa, foi contratada para elaborar as especificações técnicas relativas aos equipamentos e sistemas operacionais ${ }^{4}$.

Outros grupos, de outras nacionalidades, poderiam ter sido contratados para esse serviço de especificações técnicas, mas percebe-se que os franceses compreenderam mais rapidamente as condições de produção nacional e os rumos das políticas públicas de protecionismo, além de estarem mais bem posicionados junto à burocracia técnica da Companhia do Metrô.

Técnicos japoneses tentaram por diversas vezes vender seu pacote tecnológico (projeto, construção, equipamentos, sistemas de automação etc.) para a construção do monotrilho. Na década de 1970, optaram por traçados e tecnologias distintas do metrô subterrâneo tradicional por

\footnotetext{
${ }^{4}$ Segundo Arras, a abordagem francesa nos países estrangeiros consistia primeiramente em se aproximar de dirigentes (aí incluso todos os agentes de decisão que conseguissem identificar) de cidades com mais de um milhão de habitantes, que, na sua visão, necessariamente precisam de sistemas de transportes urbanos de alta capacidade, mostrando a relevância de se construírem metrôs subterrâneos, demonstrando que outras soluções são em geral inadequadas, mostrar a experiência francesa e elaborar projetos de soluções específicas.
} 
considerarem que nas áreas mais centrais as decisões já teriam sido tomadas, não havendo espaço para seus serviços, recomendando assim as ligações Ilha do Governador a Jacarepaguá ou Estácio a Pavuna, distantes dos problemas das áreas sobrecarregadas em deslocamentos.

Todos os projetos de arquitetura e os projetos de engenharia complementares foram feitos por escritórios nacionais, mais especificamente, escritórios locais, sediados no Rio de Janeiro, não sendo observadas quaisquer tentativas de quebra desse mercado por equipes estrangeiras ou mesmo de outros estados.

Cabe comentar a conveniência da elaboração de estudos sofisticados de transportes que exigiam um grande número de informações para alimentar métodos de modelagem sofisticados e que, no caso do Metrô-RJ, vieram a definir um traçado já consagrado em vários estudos anteriormente elaborados, a maior parte baseada mais no bom senso e na experiência de técnicos locais do que em análises complexas. Já no início dos anos 1970, o International Bank for Reconstruction and Development publicou o Economics Working Paper no. 73, “A Framework for Urban Development Studies” ${ }^{5}$, que, após uma extensa revisão dos estudos elaborados na década anterior nos Estados Unidos e em países em desenvolvimento, afirmava que as simulações de transporte e uso do solo em meio urbano utilizadas foram ineficientes em contribuir com o planejamento do desenvolvimento urbano, e que a utilização de complexos modelos de simulação para o planejamento dos transportes urbanos requeriam dados mais confiáveis e técnicas de análise que não estavam ainda disponíveis nem mesmo em países desenvolvidos. Concluiu que extrapolar a experiência americana de construção de modelos complexos deveria ser evitada em países em

\footnotetext{
${ }^{5}$ INTERNATIONAL BANK FOR RECONSTRUCTION AND DEVELOPMENT. A Framework for Urban Development Studies. Economics Working Paper no. 73, Mars 1970. 40 p., elaborado por Koichi Mera, 40 páginas.
} 
desenvolvimento e que a avaliação de projetos prioritários teria melhores resultados se conduzida com o uso de técnicas simples e econômicas.

Adicionalmente, o estudo feito por Richard Darbèra ${ }^{6}$, relativo à utilização de métodos clássicos de planejamento dos transportes urbanos, vai mais além e indica que os modelos concebidos em países desenvolvidos nem sempre tratam das categorias (modos e uso do solo) mais relevantes encontradas em países em desenvolvimento. A calibração desses modelos exige informações que raramente podem ser encontrados nas estatísticas locais e que, na grande maioria das vezes, não podem ser produzidos com os orçamentos alocados para os estudos. Cita exemplos de que, em grande parte dos casos, a solução já é conhecida e que a utilização dos modelos só vem legitimar escolhas já feitas. Avança algumas conclusões relativas às razões de se contratar consultores estrangeiros, e dentre elas está a da neutralidade científica e a garantia de se apresentar projetos nas formatações que sejam aceitáveis pelas agências de financiamento. No entanto, argumenta que quando a base política do contratante dos estudos é fraca, o estudo é inconclusivo e é rapidamente esquecido. Quando essa base se fortalece, muitas vezes o projeto volta a ser cogitado, geralmente sob a responsabilidade de outro consultor e com pequenas diferenças que justificam um novo estudo.

Nesse sentido, o caso dos estudos feitos para o Metrô-RJ é exemplar, pois a concepção de traçado e tecnologia se manteve substancialmente a mesma durante os quarenta anos de tentativas, reforçado ou enfraquecido conforme a força política da administração que o apresentava e finalmente lastreado em modelo de grande complexidade, invocando seriedade científica, embora produzido

\footnotetext{
${ }^{6}$ DARBÈRA, R. Methodologial and Institutional Issues in Urban Transportation Planning for Less Developed Countries. In: PTRC - Planning and Transport, Research and Computation - Annual Summer Meeting. Warwick, Grã-Bretanha, jul. 1979. 12 p.
} 
num tempo de projeto absolutamente inadequado à produção de dados e de conclusões. Também passou por consultores estrangeiros de nacionalidades diversas, sendo as conclusões praticamente as mesmas, com exceção dos grupos japoneses. Podemos afirmar que o estudo conclusivo de 1968 veio legitimar uma decisão já tomada pela administração Negrão de Lima, enquanto governador, já fortemente apoiada pelo mesmo agente enquanto prefeito, dez anos antes.

Financiadores dos empreendimentos (estudos e implantação) ligados aos sistemas de transportes

Todos os estudos realizados por projetistas estrangeiros especificavam a tecnologia de seus países propondo, na maioria das vezes, que a implantação do Metrô-RJ fosse contratada pelo sistema "turn key", acompanhada de financiamento de bancos de seus locais de origem para aquisição de materiais - equipamentos e sistemas de automação.

No entanto, a Companhia do Metrô $^{7}$ fixou uma diretriz no sentido de que a própria companhia deveria licitar obras e equipamentos, nas diversas fases da construção, participando e estabelecendo as regras para todo o processo, com o objetivo de obter os maiores índices de nacionalização possíveis trazendo conhecimento técnico para o país. Essa orientação liberou a Companhia do Metrô para buscar os créditos que melhor respondessem às condições de endividamento da empresa, independentemente dos fornecedores.

\footnotetext{
${ }^{7}$ Segundo informações de Bruno Costa Soares - Diretor Financeiro e Administrativo da Companhia do Metrô-RJ durante o Governo da Fusão em entrevista já citada.
} 
Não foi possível observar, a partir da análise de contratos de financiamento e de relatos dos responsáveis pelo Metrô à época, qualquer influência de bancos financiadores estrangeiros para abertura ou garantia de mercado para empresas fornecedoras oriundas de seus países de origem. Segundo Bruno Costa Soares ${ }^{8}$, as decisões foram tomadas pelos dirigentes do Metrô em função das condições favoráveis de taxas de juros; critério utilizado tanto para bancos nacionais quanto estrangeiros. No entanto, embora as condições financeiras fossem inicialmente consideradas adequadas, as operações de crédito no mercado londrino acabaram resultando num dinheiro caro, pois tiveram um prazo de carência muito curto e o recálculo das taxas de juros também se deu em intervalos de tempo curtos - a cada seis meses. Essas condições só se justificam para atividades com retorno rápido, o que não é o caso de investimentos em sistemas metroviários, para o qual outros tipos de empréstimo seriam mais adequados - ligados a bancos de desenvolvimento com longos prazos de carência e baixas taxas de juros e/ou aqueles vinculados à compra de equipamentos, também com prazos e juros mais convenientes. Esses recursos foram utilizados principalmente para os pagamentos de desapropriações e para a construção civil.

Com relação à busca de recursos para a compra de materiais, as condições de crédito foram favoráveis pois, no caso dos materiais de origem nacional houve aporte do FINAME, e no caso dos materiais estrangeiros foram contratados créditos vinculados à compra desses equipamentos. Nessas condições, a empresa fornecedora do serviço oferecia crédito junto a um banco parceiro, configurando crédito vinculado, em geral com condições favoráveis - prazos mais longos e juros menores do que os não vinculados. Como visto no capítulo anterior, os recursos externos

\footnotetext{
${ }^{8}$ Bruno da Costa Soares informa que os empréstimos tomados junto ao mercado financeiro londrino tinham como contratantes um grupo de bancos denominado EUROBRÁS constituído por uma centena de instituições, das quais cerca de 33\% do capital era do Banco do Brasil e o restante de bancos japoneses, alemães, suíços e americanos. Em situação de igualdade quanto às condições das operações com outros grupos financeiros, optou-se por esse grupo em função do fortalecimento da instituição nacional.
} 
vinculados ao fornecimento de equipamentos atingiram cerca de uma terça parte do montante de empréstimos não vinculados.

Desta forma, é provável que o custo dos equipamentos pudesse ter sido mais baixo se a opção tivesse sido por fornecimentos do tipo "turn-key", mas ao decidir pelo gerenciamento da definição de fornecedores, da compra e da instalação dos equipamentos, a Companhia possibilitou um ganho tecnológico para a indústria nacional.

\section{Produtores da Infra-estrutura de Transportes}

Como pudemos observar através das informações já apresentadas, as companhias estrangeiras não conseguiram entrar no mercado nacional para a construção civil do Metrô-RJ, embora tenham trabalhado para isso junto às empresas de estudos e projetos. Mesmo tendo vencido uma das primeiras concorrências para realização de obras, as empresas francesas não chegaram a trabalhar nas obras civis.

As companhias empreiteiras estrangeiras não tiveram clareza sobre as características do setor da construção civil no Brasil no que se refere a dois aspectos principais:

- que as empreiteiras nacionais já tinham capacidade técnica na área da construção de obras civis e que lutariam pela manutenção do mercado, bem como se posicionariam contra projetos do tipo “turn-key” e

- que uma aproximação no nível federal seria mais efetiva do que junto às instituições estaduais, uma vez que dificilmente a obra sairia sem o apoio do Governo Federal, pois o estado não teria autonomia financeira para construir e, adicionalmente, que os governadores do então Estado da 
Guanabara - Negrão de Lima e Chagas Freitas - faziam, numa certa medida, oposição ao grupo no poder em Brasília.

As grandes construtoras nacionais não participaram dos processos licitatórios iniciais, pois aparentemente seus dirigentes não acreditavam que a obra seria realizada e tinham à época outros contratos. A Camargo Corrêa, por exemplo, no início da década de 1970 era responsável por grandes obras tais como: o Metrô de São Paulo, o Aeroporto de Manaus, a Transamazônica e a Ponte Rio-Niterói. Entre 1974 e 1977, período em que se concentraram as licitações de praticamente toda a Linha 1 e do Pré-metrô, essa empresa iniciava os trabalhos de construção das Usinas Hidrelétricas de Tucuruí e Itaipu e se preparava para disputar as obras do Aeroporto Internacional de Cumbica e da Usina Hidrelétrica de Guri na Venezuela9 .

A partir do momento em que a realização das obras pareceu se concretizar, grandes empresas começaram a se posicionar para entrar no processo. As empresas locais, de médio porte, participaram do processo de concorrência desde o princípio, mas, com a concordata da ECISA, não conseguiram manter sua hegemonia junto à contratante. A Companhia do Metrô-RJ afirmava a necessidade de contratar empresas sólidas que conseguissem responder aos seus cronogramas de pagamento, fortemente desfavoráveis para os contratados (razão de concordata da ECISA).

A partir do posicionamento do Metrô que explicitamente favorecia a escolha de grandes construtoras, as empresas locais, de porte pequeno e médio ficaram impedidas de disputar diretamente as concorrências, nem mesmo se conseguissem atender às condições do Metrô

\footnotetext{
${ }^{9}$ Segundo QUINTELLA, W. Memórias do Brasil Grande: a história das maiores obras do país e dos homens que a fizeram. São Paulo: Editora Saraiva, 2008. 426 p.
} 
relativas a valor mínimo de capital social e número de funcionários - que poderiam ser cumpridas ao se organizarem em consórcios. Essa empresas foram claramente repelidas pelo Metrô.

Para substituição de empresas concordatárias foi adotada a solução de negociação de contrato entre elas e algumas grandes construtoras, com a anuência do Metrô, de forma que não fosse aberta nova concorrência para esses trechos.

Mesmo invocando o Decreto Estadual no. 2.571/79 do Governo do Estado que protegia as empresas locais em situações concorrenciais de igualdade, resultado de severas pressões locais Associação de Empreiteiros do Rio de Janeiro e da FIRJAN -, mesmo apelando diretamente ao governador - de oposição ao Governo Federal -, mesmo com o assunto amplamente veiculado pela imprensa, as pequenas e médias empreiteiras formalmente não conseguiram espaço. A única empresa local que trabalhou contratada diretamente pela companhia, competindo com as grandes empreiteiras de outros estados foi a ECISA que chegou a manter cerca de $60 \%$ do volume total de contratos. Afastada, a ECISA responsabilizou diretamente a Companhia do Metrô-RJ pela sua concordata e conseqüente afastamento dos canteiros.

O maior volume de obras foi efetivamente feito por grandes empresas de construção civil e originária de outros estados - Queiroz Galvão, Mendes Junior, CETENCO e CBPO. Certamente, não foi sem muita luta que as empresas locais de médio e pequeno porte deixaram de participar do processo de contratação direta e, na realidade, muitas delas participaram efetivamente das obras como sub-contratadas das grandes construtoras, sem, no entanto, conseguir um atestado de participação diretamente fornecido pelo Metrô. A exceção foi a Itapema, pois, especializada na 
relocação da infra-estrutura urbana de saneamento, cabos de eletricidade, telefone etc., acumulou know-how a cada tarefa e, através de pequenos contratos, esteve presente boa parte do tempo.

Cabe observar que toda essa disputa entre empreiteiros locais, cariocas e fluminenses, e grandes empresas de expressão nacional se deu no mês seguinte à edição do Decreto Estadual no. 2.571/79, o que demonstra a penetração dos interesses locais na administração estadual, sendo bastante veiculada pela imprensa carioca $^{10}$. Nessa confrontação de interesses entre os empreiteiros sediados no Rio de Janeiro e aqueles que contavam com o apoio da Companhia do Metrô-RJ, saem favorecidas as grandes companhias, embora até mesmo a FIRJAN - Federação das Indústrias do Estado do Rio de Janeiro, entidade de grande influência, tenha se posicionado na defesa dos interesses locais.

Desta forma, pode-se concluir que, se pressões existiram para que a obra tivesse início, foram pressões inicialmente locais, mas que não se reverteram efetivamente em contratos para as empresas locais. Quando as grandes construtoras perceberam que a obra seria realizada, passaram a se interessar pelo negócio e efetivamente conseguiram participar. No entanto, a década de 1970 se constituiu num momento de grande aquecimento da indústria da construção civil no Brasil inteiro e muitas grandes construtoras não se interessaram pelas obras do Metrô-RJ, ocupadas que estavam com a construção de grandes estradas, com o Metrô-SP, com usinas hidrelétricas etc.

\footnotetext{
${ }^{10}$ Além das entrevistas mencionadas, foram pesquisados os jornais de grande circulação - Jornal do Brasil e O Globo, no período de 1978 a 1980.
} 
Entrevistas com o Diretor do Consórcio ECISA-ECEL (posteriormente Diretor da ESUSA) e com a Assessoria Técnica da Mendes Junior ${ }^{11}$, explicam a prática de reserva de mercado que as empresas da construção civil nacionais certamente faziam garantindo suas fatias desse mercado: através dos excelentes contatos junto aos agentes de decisão na esfera federal de governo. Até regionalmente, a prática parecia ser essa, o que pode ser observado na construção do Metrô de Belo Horizonte - que barrou a entrada de empresas de outros estados, através de pressão direta junto ao governador.

É extremamente esclarecedor o livro de Wilson Quintella, já citado, que num depoimento em que descreve a forma de trabalhar da Construtora Camargo Corrêa ao longo dos cerca dos 40 anos descritos, ressalta alguns pontos críticos para o sucesso na captação e manutenção de negócios. Além da capacidade técnica para a resolução de problemas, o autor afirma que sem a construção de um relacionamento sólido, não há chance de sucesso. Para tanto, destaca a importância dos laços de família, de local de origem e compadrio e a formação de amizades pessoais que se revertem em indicações e confiança dos clientes, mais particularmente de governantes ${ }^{12}$. Desta forma, os contatos que as grandes empresas de construção civil nacionais possuíam junto aos

\footnotetext{
${ }^{11}$ Entrevistas com Waldner Paschoal, Diretor do Consórcio ECISA-ECEL e posteriormente Diretor da ESUSA em 15 fev. 1982 e com Paes Leme, Assessor da Diretoria da Mendes Jr. em 11 fev. 1982.

${ }^{12}$ Sobre os laços de família, Wilson Quintella afirma na página 41 que: “[...] Como o Silvio (Brand Corrêa) se relacionava bem como o Adhemar (de Barros), o Sebastião (Camargo) se associou a ele para ter acesso às obras feitas para o governo.” (dando origem à Camargo Corrêa) Parênteses nossos. Na realidade Silvio Brand Corrêa era primo de Adhemar de Barros. Através da influência do mesmo Silvio a empresa viabilizou vários contratos para extensão da malha ferroviária do Estado de São Paulo. Ver página 45. Sobre a formação de amizades estratégicas, Quintella cita o papel muito importante desempenhado por sua mulher e filhos em várias ocasiões, em relacionamentos que perduraram por muito tempo e exemplifica sua amizade com Fernando Corrêa da Costa, que foi governador de Mato Grosso e que lhe proporcionou um papel importante na Comissão Interestadual da Bacia do Paraná e Uruguai, que resultou em atuações importantes da Camargo Corrêa na região, com Israel Pinheiro nas obras de construção em Brasília e muitas outras figuras notáveis da administração pública nacional.
} 
dirigentes públicos lhes possibilitavam exercer influências para o direcionamento de muitas ações desses mesmos dirigentes.

Quando o Governo Federal resolveu apoiar firmemente o Metrô-RJ e que portanto, o empreendimento ganhou fôlego, as grandes construtoras entraram no processo, ficando as demais empresas alijadas; lembrando que esse momento coincide com a finalização de outra grande obra na região, a Ponte Rio-Niterói e que a oportunidade de reposicionar um grande contingente de mão-de-obra seria bem-vinda.

Pode-se afirmar que as grandes construtoras não influenciaram diretamente na decisão de implantar o Metrô-RJ, mas foram as grandes propulsoras da obra quando o Governo Federal passou a dar seu apoio integral, pois passaram a, indiretamente, financiar as obras com seu capital de giro. As tradicionais empreiteiras construtoras do Rio de Janeiro foram sendo formalmente afastadas.

Mesmo consumindo grande parte dos recursos, não podemos afirmar que os empreiteiros lucraram significativamente com as obras. Estes afirmam que não houve grandes ganhos nas obras do Metrô-RJ e uma possível evidência dessa hipótese foi a concordata da ECISA e mais tarde, da construtora paulista Beter, que não conseguiram manter seus contratos nas condições de endividamento que a Companhia do Metrô lhes obrigava. Somente as grandes construtoras conseguiram participar da obra nessas condições. Outra evidência de que as condições para trabalhar no Metrô não eram tentadoras, foi o fato da CBPO, por exemplo, se candidatar a construir somente um lote de pequenas dimensões na clara iniciativa de participar para poder 
comprovar sua experiência na construção de metrôs para concorrências futuras, e não participando nas demais licitações do Metrô-RJ ${ }^{13}$.

\section{Produtores de material rodante e de equipamentos para o setor}

As indústrias sediadas no Rio de Janeiro não tinham condição de produzir quase nenhum material rodante ou equipamentos para os sistemas de automação do Metrô-RJ. No entanto, empresas sediadas em São Paulo - como a MAFERSA e a COBRASMA - tiveram condições de atender grande parte da demanda por material rodante e a fabricação dos carros foi repartida entre elas. Associadas a empresas estrangeiras, a MAFERSA com grupos americanos e a COBRASMA com grupos europeus - franceses, belgas, dinamarqueses e alemães -, elas desenvolveram projetos e executaram a maior parte do material rodante. A MAFERSA chegou a um índice de nacionalização de 75\% e a COBRASMA a cerca de 60\%.

As empresas nacionais produtoras de material rodante eram representadas pela ABIFER Associação Brasileira da Indústria Ferroviária, que trabalhou no sentido de viabilizar a participação das empresas brasileiras no empreendimento; essas empresas, além de terem condições técnicas de suprir as demandas, também estavam com sua capacidade de produção ociosa. No entanto, segundo avaliação obtida em entrevista com Fábio Kowarick, Diretor Executivo da ABIFER - Associação Brasileira da Indústria Ferroviária, os contatos da ABIFER e

\footnotetext{
${ }^{13}$ Acrescentam os empreiteiros que nem mesmo na construção do Metrô-SP onde os recursos eram mais abundantes, houveram lucros espetaculares, exceção feita à Camargo Correa que pôde dar preços mais altos porque introduziu nova tecnologia, shield, nas obras paulistanas.
} 
dos produtores de material rodante com os dirigentes do Metrô-RJ e com outros agentes públicos não foram determinantes na decisão mais geral de se construir o Metrô-RJ ${ }^{14}$.

Nas áreas de sistemas de sinalização, bilhetagem, piloto automático etc, a indústria nacional não tinha experiência; foram os grupos franceses que efetivamente forneceram esses equipamentos, lembrando que a SOFRETU, empresa de estudos e projetos francesa, foi contratada sem licitação para a especificação desses equipamentos e para a elaboração das normas para a concorrência, com a justificativa de que a capacitação da indústria francesa no setor era bastante destacada e vários empreendimentos semelhantes estavam em implantação em várias cidades do mundo nessa época, e que portanto seria normal que o Metrô-RJ buscasse a experiência francesa. No entanto, a essa altura, a equipe técnica do Metrô-SP já era bastante experiente no que se refere às especificações técnicas e poderia ter sido consultada pelos dirigentes do Metrô-RJ. A Companhia do Metrô-RJ efetivamente optou pelos consultores estrangeiros, de procedência francesa, e podese fazer uma ligação entre produtos especificados e empresas contratadas.

Para esse tipo de equipamento, os franceses forneceram também a linha de crédito. Outros grupos, de outras nacionalidades, poderiam ter sido contratados para esses serviços, mas pode-se também afirmar que os franceses estavam mais bem posicionados junto à burocracia técnica da Companhia do Metrô-RJ ao conseguirem o contrato de especificação de equipamentos sem licitação. Era indiscutível a experiência francesa na área de equipamentos e sistemas em geral, mas não se exclui a hipótese de que, em se contratando uma empresa de consultoria francesa para

\footnotetext{
${ }^{14}$ Entrevista realizada em 03 fev. 1982 com Fábio Kovarick - Diretor Executivo da ABIFER - Associação Brasileira da Indústria Ferroviária. Carlos Jorge, engenheiro da Companhia do Metrô-RJ informou em entrevista realizada em 12 mar. 1982 que a decisão para repartir o contrato para a construção do material rodante entre as duas empresas foi tomada pela esfera federal, bem como posteriormente aceitar aditivo solicitado pela MAFERSA, que poderia entrar em concordata e não honrar o contrato com o Metrô-RJ, em função dos resultados desfavoráveis na concorrência de Porto Alegre.
} 
o trabalho de especificações e normas para as concorrências de fornecimento, esses requisitos não tenham pesado fortemente para decisões por equipamento da mesma origem.

\subsection{Os Consumidores dos Transportes Urbanos}

\section{A Valorização Fundiária e Imobiliária}

Apesar da maioria das propostas e especulações relativas ao traçado terem chegado ao consenso de indicar a mesma ligação Zona Norte - Zona Sul durante 40 anos, evidentemente propostas de amplo conhecimento público, veiculadas na grande imprensa e nos circuitos técnicos e acadêmicos, não foi possível observar no conjunto de fontes analisado, uma mobilização do empresariado imobiliário no sentido de criar um estoque de terrenos ao longo do traçado do Metrô-RJ, com a finalidade de se apropriar da valorização que uma infra-estrutura de transportes de grande capacidade inevitavelmente traria. Primeiramente, as áreas centrais foram sendo gradativamente adensadas nas décadas de 1930 a 1960, com a substituição dos usos habitacionais pelos comerciais e de serviços, especialmente com as desapropriações e demolições das áreas de baixa renda, cortiços e casas de cômodos, necessárias para a implantação das obras do Prefeito Henrique Dodsworth - avenida Presidente Vargas, em especial - e posteriormente com o desmonte do Morro do Castelo e a criação de extensas áreas para novas edificações em altura, num processo de valorização e verticalização ${ }^{15}$, independentemente da implantação de um metrô. Desta forma, a disponibilidade de terrenos desocupados foi se tornando nula. Em segundo lugar,

\footnotetext{
${ }^{15}$ De grande interesse é a descrição de Rachel Sisson sobre os três centros do Rio de Janeiro, primeiramente o Largo do Paço, no período colonial, o Campo de Santana, no período imperial, e a Praça Floriano Peixoto no período republicano. O artigo traz foto sem data da área para urbanização da recém aberta Esplanada do Castelo e o início da maciça verticalização que se seguiria. SISSON, R. Os três Centros do Rio. Revista Municipal de Engenharia, Prefeitura da Cidade do Rio de Janeiro, out./dez. 1983, v XXXIX. p. 55-71.
} 
até o Governo da Fusão (1974-1979), os empreendedores locais e até mesmo a população não acreditavam na realização da obra, e outras áreas da cidade, distantes do eixo do Metrô, eram mais atrativas para a reprodução do capital empresarial.

No Rio de Janeiro, a proximidade da orla marítima, por exemplo, tem se constituído num fator de valorização imobiliária muito mais significativo do que incrementos de acessibilidade. Os investimentos imobiliários na direção da Zona Sul, na maioria das vezes, antecederam em muitos anos a abertura de canais de acesso adequados, como é o caso da Barra da Tijuca. A esse respeito é interessante observar a tese de doutoramento de Luiz Cesar de Queiroz Ribeiro, "Da Propriedade Fundiária ao Capital Incorporador: as formas de produção da moradia na cidade do Rio de Janeiro", onde o autor afirma a importância da incorporação junto à orla, com o extraordinário aumento da produção de edifícios de apartamentos e a diminuição da produção pequeno-burguesa. Nas suas palavras:

\begin{abstract}
Este novo setor (incorporadores) inventa um novo produto, “o apartamento-zona sul” destinado às camadas de alto poder aquisitivo... Isto significa dizer que a verticalização da cidade não é uma necessária conseqüência do encarecimento da terra, em função da sua escassez, num sítio caracterizado por montanhas e mar. ${ }^{16}$
\end{abstract}

A população de Copacabana chegou a crescer na década 1940 a 1950 cerca de 74,35\% enquanto a população da cidade como um todo cresceu 34,76\%; na década seguinte, o crescimento populacional desse mesmo bairro foi de $85,96 \%$ e o da cidade 39,11\%. O número de domicílios cresceu muito mais do que o número de edifícios, o que demonstra um processo intenso de verticalização nos bairros de Copacabana. O mesmo ocorreu nos bairros de Ipanema e Leme.

\footnotetext{
${ }^{16}$ RIBEIRO, L. C. de Q. Da Propriedade Fundiária ao Capital Incorporador: as formas de produção da moradia na cidade do Rio de Janeiro. 1991, 326 p. Tese de Doutoramento apresentada à Faculdade de Arquitetura e Urbanismo, Universidade de São Paulo, 1991. Ver p. 243.
} 
Ainda, os valores médios para comercialização dos terrenos e dos prédios na Zona Sul da Cidade, cresceram significativamente no período de 1949 a 1957, conforme demonstrado pelo autor acima citado, mesmo sem um aumento significativo de acessibilidade.

O artigo “Contribuição do Estudo sobre o Valor das Terras no Município do Rio de Janeiro”, de Oliveira, Vilhena, Silva e Tibúrcio ${ }^{17}$, publicado na Revista Municipal de Engenharia, traz uma comparação do valor do terreno padrão nas datas 1973 e 1980 que permite refletir sobre como os interesses imobiliários nas proximidades do traçado da rede prioritária do Metrô se comportaram. Tendo em vista que as obras do Metrô-RJ oficialmente foram iniciadas em 1970 e prosseguiram em ritmo lento até 1974, os valores coletados no ano de 1973 ainda não refletem a influência das obras nos preços dos terrenos lindeiros, mas sim dos demais fatores determinantes do preço, tais como: localização, vizinhança, presença de grupos sociais específicos, disponibilidade de equipamentos e infra-estrutura, condições naturais, dentre outros. No entanto, como o Governo da Fusão não apenas inaugurou o $1^{0}$. trecho - Glória/Praça Onze - mas também deixou obras iniciadas em todo o percurso prioritário, pode-se afirmar que os valores coletados no ano de 1980 já refletem as ações do Metrô, além dos demais fatores de localização significativos. Assim, os valores da terra no município, conforme apresentados na Tabela 12 - Valores do Terreno Padrão em bairros selecionados do Rio de Janeiro nas imediações da Rede Prioritária do Metrô-RJ 1973 e $1980^{18}$, construída a partir do estudo citado, puderam ser comparados através de unidades de valor estáveis e permitem a formulação de algumas hipóteses.

\footnotetext{
${ }^{17}$ OLIVEIRA, A. M. S. L.; VILHENA, L. M.; SILVA, M. L. A.; TIBÚRCIO, S. M. N. O. Contribuição do Estudo sobre o Valor das Terras no Município do Rio de Janeiro. Revista Municipal de Engenharia. Rio de Janeiro: Prefeitura da Cidade do Rio de Janeiro, vol XXXIX, p. 72-85, out./dez. 1983.

${ }^{18}$ Os números apresentados representam o valor para fins tributários elaborado pela Secretaria Municipal da Fazenda. Não representam o valor de mercado, mas ao abranger todo o território municipal, permitem comparações seguras.
} 
Tabela 12 - Valores do Terreno Padrão em Bairros Selecionados do Rio de Janeiro nas imediações da Rede Prioritária do Metrô-RJ 1973 e 1980

\begin{tabular}{|c|c|c|c|c|}
\hline & BAIRRO & $\begin{array}{c}1973 \\
\text { Valor do Terreno } \\
\text { Padrão ORTN } \\
\end{array}$ & $\begin{array}{c}1980 \\
\text { Valor do Terreno } \\
\text { Padrão ORTN } \\
\end{array}$ & $\begin{array}{c}\text { Incremento } \\
\text { Período 1973-1980 } \\
\% \\
\end{array}$ \\
\hline \multirow{8}{*}{ LINHA 1} & Tijuca & 4.551 & 5.961 & 30,98 \\
\hline & Mangue & 3.451 & 1.497 & $-56,62$ \\
\hline & Centro & 21.226 & 47.610 & 124,30 \\
\hline & Glória & 8.770 & 8.811 & 0,47 \\
\hline & Catete & 6.068 & 6.811 & 12,24 \\
\hline & Flamengo & 11.398 & 16.431 & 44,10 \\
\hline & Botafogo & 9.063 & 12.645 & 39,52 \\
\hline & Copacabana & 20.026 & 15.792 & $-21,15$ \\
\hline \multirow{14}{*}{ LINHA 2} & Estácio & 989 & 687 & $-30,54$ \\
\hline & São Cristóvão & 1.942 & 811 & $-58,24$ \\
\hline & Maracanã & 2.430 & 5.260 & 116,46 \\
\hline & Maria da Graça & 378 & 401 & 6,08 \\
\hline & Del Castilho & 418 & 446 & 6,69 \\
\hline & Inhaúma & 454 & 423 & $-6,83$ \\
\hline & Engenho da Rainha & 296 & 195 & $-34,12$ \\
\hline & Thomaz Coelho & 215 & 173 & $-19,53$ \\
\hline & Vicente de Carvalho & 369 & 321 & $-13,01$ \\
\hline & Irajá & 498 & 454 & $-8,84$ \\
\hline & Colégio & 204 & 201 & $-1,48$ \\
\hline & Coelho Neto & 407 & 387 & $-4,92$ \\
\hline & Acari & 193 & 105 & $-45,60$ \\
\hline & Pavuna & 234 & 130 & $-44,44$ \\
\hline \multirow{3}{*}{$\begin{array}{l}\text { Localizações } \\
\text { Nobres da Zona } \\
\text { Sul }\end{array}$} & Ipanema & 16.543 & 24.945 & 50,79 \\
\hline & Leblon & 16.543 & 24.389 & 47,43 \\
\hline & Barra da Tijuca & 1.092 & 1.755 & 61,71 \\
\hline
\end{tabular}

Fonte: OLIVEIRA, A. M. S. L.; VILHENA, L. M.; SILVA, M. L. A.; TIBÚRCIO, S. M. N. O. Contribuição do

Estudo sobre o Valor das Terras no Município do Rio de Janeiro. Revista Municipal de Engenharia. Rio de Janeiro: Prefeitura da Cidade do Rio de Janeiro, vol XXXIX, p. 72-85, out./dez. 1983, p. 76 e 77.

Com relação às áreas mais centrais e à Zona Sul, pode-se observar que:

- em 1973, o valor do terreno padrão no Centro correspondia ao terreno mais caro do município, seguido pelos valores de Copacabana, Ipanema e Leblon.

- em 1980, o valor do terreno em Copacabana perdeu cerca de 20\% de valor, com relação a 1973, enquanto que os terrenos do Centro mais que duplicaram de valor; Ipanema e Leblon, por sua vez, ganharam valorização de cerca de 50\%. 
- os terrenos mais distantes na Zona Sul, Barra da Tijuca, tiveram valorização relativa superior a Ipanema e Leblon, cerca de 61\%.

Pode-se dizer que ocorreu uma valorização constante e expressiva nos bairros nobres - Ipanema e Leblon e ainda Laranjeiras e Jardim Botânico - e uma “criação de valor” nas novas frentes de expansão da Zona Sul - Barra da Tijuca. O excesso de oferta, a ausência de infra-estrutura e as distâncias ao centro conferiam aos terrenos da Barra da Tijuca valores absolutos ainda muito baixos, 14 vezes menores do que em Ipanema, mas crescimentos de 253\% em Jacarepaguá e 174\% no Recreio dos Bandeirantes já sinalizavam não apenas uma alteração de uso, de rural para urbano, como também o interesse do mercado imobiliário na produção de moradias para as classes de renda de maior poder aquisitivo. O bairro de Copacabana não conseguiu manter sua condição de preços, refletindo a condição de saturação e esgotamento do modelo "apartamentozona sul” nesse bairro e conseqüente redução da qualidade de vida do mesmo, com sensível redução de valores absolutos que foram ultrapassados pelas localizações Ipanema e Leblon na década de 1970.

O Centro, por sua vez, teve o valor da terra um pouco mais do que dobrado, refletindo primeiramente a escassez de terrenos e certamente, os efeitos do processo de renovação urbana com a substituição de edificações antigas por prédios destinados a usos não residenciais cada vez mais altos na avenida Rio Branco e na Cinelândia. Mais do que os efeitos de aumento de acessibilidade, a presença de um importante equipamento como o Metrô ajudou a retardar a fuga de investimentos da área central, ficando mantida e até mesmo reforçada a situação de centralidade dessa área até os dias de hoje. 
Se as áreas centrais já eram densamente ocupadas quando as obras do Metrô-RJ foram iniciadas, o que acarretou enormes dispêndios em desapropriações, os bairros terminais do trecho prioritário, Botafogo e Tijuca, apesar de quase não possuírem terrenos vagos, apresentavam ocupação horizontal extensiva de média densidade. Grande parte das atividades terciárias no Rio de Janeiro se concentra até hoje no Centro e na direção da Zona Sul, chegando até Copacabana, Ipanema e Leblon. Botafogo, bairro de passagem, mas ainda assim de certa forma preservado da verticalização maciça que já acontecia em Copacabana, passou a sofrer um processo de transformação muito intenso com as obras do Metrô-RJ, mesmo que sua acessibilidade não tenha sido profundamente aumentada. Apresentou significativa valorização dos preços de terrenos, de cerca de $40 \%$, apesar dos inconvenientes que as frentes de obra causavam nas principais vias do bairro.

Segundo informações obtidas através de entrevista com José Conde Caldas, representante da ADEMI - Associação dos Dirigentes do Mercado Imobiliário, como a princípio não se acreditava na obra do Metrô, o setor imobiliário só começou a se movimentar a partir de 1975, quando se constatou o impulso que as obras começavam a ter a partir do Governo da Fusão. “[...] Houve alguma estocagem a partir da compra de casas velhas, uma pequena movimentação para a criação de uma reserva de terrenos, especialmente no Botafogo. ${ }^{19}$

O bairro da Tijuca - tradicional moradia de militares, muito numerosos no Rio de Janeiro, uma vez que, enquanto capital, a cidade reunia grandes agrupamentos das Forças Armadas - era uma área residencial de classe média, de média densidade, que experimentou no período 1973-1980

\footnotetext{
${ }^{19}$ Entrevista com José Conde Caldas, representante da ADEMI - Associação dos Dirigentes do Mercado Imobiliário, em 03 mar. 1982.
} 
um rápido processo de verticalização ${ }^{20}$, como uma opção de moradia a preços convenientes para a classe média, numa região de grande acessibilidade e relativamente próxima da área central. O perfil do bairro já começava a se alterar com as obras da ligação rodoviária Zona Norte - Zona Sul, através do Túnel Rebouças, iniciadas no governo de Carlos Lacerda, com um aumento considerável de acessibilidade à orla marítima. Embora a valorização de terrenos de cerca de 30\% nesse período não tenha sido tão expressiva, quando comparada com outros bairros da cidade, os inconvenientes da obra do Metrô na principal rua comercial do bairro, com a interdição do fluxo e o fechamento de vários negócios, certamente contribuíram para que a valorização não fosse maior. Quando as obras da estação Saens Peña e a urbanização do entorno foi finalizada, o processo de verticalização se acelerou e a crescente valorização imobiliária do bairro pôde ser sentida. Os dados de lançamentos se mantém em crescimento consistente até o ano de 1982, quando toda a atividade de incorporação imobiliária na cidade do Rio de Janeiro passa a decrescer em todos os bairros, inclusive na Zona Oeste ${ }^{21}$.

Ainda no entorno da Linha 1, os bairros do Catete e da Glória foram bastante modificados com as desapropriações feitas para as obras do Metrô que, em seguida, destruíram vastas porções de um casario antigo, substituindo-as por vias, praças e calçadas que muito descaracterizaram esses bairros. O mesmo aconteceu no Centro, nas imediações do Largo do Carioca e da Cinelândia.

\footnotetext{
${ }^{20}$ Segundo RIBEIRO, L. C. de Q. Da Propriedade Fundiária ao Capital Incorporador: as formas de produção da moradia na cidade do Rio de Janeiro. 1991, 326 p. Tese de Doutoramento apresentada à Faculdade de Arquitetura e Urbanismo, Universidade de São Paulo, 1991, página 293, houve uma expansão significativa de lançamentos na Zona Norte a partir de 1979, especialmente nos bairros da Tijuca e Vila Isabel, que concentravam cerca de 66\% da área lançada na Zona Norte.

${ }^{21}$ RIBEIRO, L. C. de Q. Da Propriedade Fundiária ao Capital Incorporador: as formas de produção da moradia na cidade do Rio de Janeiro. 1991, 326 p. Tese de Doutoramento apresentada à Faculdade de Arquitetura e Urbanismo, Universidade de São Paulo, 1991, página 293.
} 
Esta perdeu o Palácio Monroe ${ }^{22}$, que abrigou o Senado, ganhando algumas ruas para pedestres. Os preços de terrenos no bairro da Glória apresentaram no período 1973-1980 incrementos que não chegam a $1 \%$, embora o bairro tenha sido um dos primeiros a ser beneficiado com a inauguração da estação terminal de mesmo nome em 1979. O Catete experimentou uma valorização imobiliária maior, cerca de $12 \%$, ainda que sofresse com os inconvenientes das obras, cujos trabalhos se alongaram ainda por vários anos.

Na direção da Zona Norte, na região da Cidade Nova, os preços de terrenos na região do Mangue sofreram uma redução significativa de mais de 50\%, embora abrigasse a estação terminal Praça Onze. Provavelmente esses preços refletiam, no início da década de 1980, o processo de reorganização urbana ainda muito incipiente que a região experimentou com a implantação parcial do projeto da Cidade Nova e com a decadência ainda maior dos imóveis do entorno. As grandes modificações na urbanização da área da Cidade Nova, que se esperava seriam realizadas com a implantação do Metrô-RJ, só no início dos anos 1990 começaram a se concretizar.

Pode-se concluir que a dinâmica imobiliária nas áreas que a linha 1 do Metrô-RJ atravessa, no centro da cidade, não foi substancialmente alterada por causa do novo sistema de transporte, no período estudado. À exceção dos pontos terminais, Botafogo e Tijuca, o empresariado imobiliário

\footnotetext{
${ }^{22}$ O Palácio Monroe, construído em estrutura metálica e estilo eclético foi premiado na Exposição Internacional de St. Louis nos Estados Unidos em 1904. Foi reconstruído em 1906 e embora tenha sido aberto estudo para tombamento, este não foi autorizado e em 1975 o presidente Geisel assinou sua demolição, tendo como justificativa as obras do Metrô-RJ. Houve uma luta entre dois grupos: um, favorável à demolição (Jornal O Globo, arquiteto e urbanista Lucio Costa e outros) e outro, desfavorável (Jornal do Brasil, Instituto de Arquitetos do Brasil - seção Rio de Janeiro, Clube de Engenharia e outros). Engenheiros do Metrô-RJ chegaram a alterar o projeto geométrico de forma a preservá-lo e a obra foi executada também de forma a não abalar fundações e estruturas, o que destrói a argumentação de que o Palácio Monroe teria sido demolido em função do Metrô. Mesmo o presidente da Companhia do Metrô-RJ chegou a declarar que o projeto havia sido alterado para preservar a edificação. Disponível em: $<$ http://www.almacarioca.com.br/monroe.htm> Acesso em: 15 mar. 2007.
} 
- donos de terra e imóveis e incorporadores - não considerou a implantação do Metrô-RJ um fator de grande alteração da área central. Os incorporadores efetivamente desenvolveram suas atividades nos locais onde as possibilidades de adensamento e verticalização foram alteradas pela criação de acesso, ou onde esse processo de verticalização já estava em andamento pelas próprias condições de localização, e especialmente pela grande modificação das condições de produção possibilitadas pelas concessões de crédito através do SFH - Sistema Financeiro de Habitação, criado com o BNH através da Lei Federal no. 4.380 de 1964.

O mercado imobiliário tem uma lógica própria alicerçada principalmente nas facilidades de crédito e nas condições de localização dos empreendimentos que criam o sobrelucro da localização, obtido nas novas fronteiras de expansão do capital de incorporação: “[...] De um lado, pelo transbordamento em direção à Zona Norte e a alguns subúrbios; de outro, pelo novo produto: a Barra da Tijuca e os condomínios fechados”²3, nas palavras de Luiz Cesar de Queiroz Ribeiro. Em nenhum momento, este autor aponta que alterações recentes no sistema de transportes públicos na cidade do Rio de Janeiro, como o Metrô, tenham resultado num importante reflexo no comportamento do mercado, com exceção da Tijuca, que foi integrada ao Centro e à Zona Sul através do Túnel Rebouças e do Metrô.

Assim, na década de 1980, o número de lançamentos imobiliários e suas respectivas áreas apresentam um crescimento considerável na Zona Norte - Tijuca e Vila Isabel -, na direção dos subúrbios - no Méier e na Ilha do Governador - e na Barra da Tijuca, que, com exceção da Tijuca

\footnotetext{
${ }^{23}$ RIBEIRO, L. C. de Q. Da Propriedade Fundiária ao Capital Incorporador: as formas de produção da moradia na cidade do Rio de Janeiro. 1991, 326 p. Tese de Doutoramento apresentada à Faculdade de Arquitetura e Urbanismo, Universidade de São Paulo, 1991, página 292.
} 
estão fora da influência direta do Metrô, segundo o Gráfico XIII apresentado por Ribeiro ${ }^{24}$. É a Barra da Tijuca que desponta como localização privilegiada no final dos anos 1980, fortemente alicerçada nas melhorias viárias implementadas e nas novas regras de ocupação do solo com o Plano Lúcio Costa. Segundo o mesmo autor: “[...] A Barra da Tijuca expressa a repetição da lógica da incorporação imobiliária, inaugurada nos anos 40, com a “invenção” de Copacabana.”25

Nas palavras do representante da ADEMI, José Conde Caldas:

As empresas imobiliárias só investiam na Zona Sul nessa época. É só de três anos para cá (1979), com o corte de financiamento do BNH, que o setor tem partido para a Zona Norte e subúrbios (hoje com $80 \%$ da demanda), investindo numa faixa de média a baixa renda. ${ }^{26}$

Diferentemente da Linha 1, existiam à época da implantação do Pré-Metrô, grandes e tradicionais proprietários de terra nas glebas desocupadas ao longo da linha 2. Segundo este, famílias tradicionais, donas de antigas fazendas, e o próprio governo - Instituto de Previdência Social e o Ministério do Exército - eram proprietários nessa região. Iniciando as obras em todo o trecho então considerado prioritário - 37 km -, o Governo da Fusão tornou irreversível a implantação do novo sistema nessa área de baixa ocupação, o que nos leva a crer que a valorização dessa área poderia ser um fato real, proporcionando lucros para os detentores da propriedade das glebas vazias existentes.

\footnotetext{
${ }^{24}$ RIBEIRO, L. C. de Q. Da Propriedade Fundiária ao Capital Incorporador: as formas de produção da moradia na cidade do Rio de Janeiro. 1991, 326 p. Tese de Doutoramento apresentada à Faculdade de Arquitetura e Urbanismo, Universidade de São Paulo, 1991, página 293.

${ }^{25}$ Ibid., p. 307.

${ }^{26}$ Informação recolhida na entrevista citada anteriormente.
} 
Na direção da Linha 2 e do trecho onde estava prevista a implantação do Pré-Metrô pode-se observar a partir dos dados da Tabela 12 que, de maneira geral, a linha deveria atravessar uma região com preços de terrenos muito baixos e com pouca variação entre as localidades percorridas. De fato, no ano de 1973, esses eram os valores de terrenos mais baixos do município do Rio de Janeiro, semelhantes apenas às áreas mais periféricas dos subúrbios mais distantes. Com a mesma distância do centro, os valores de terrenos ao longo dos eixos da EFCB e da Leopoldina eram, pelo menos, duas vezes maiores do que na região da antiga Estrada de Ferro Rio d’Ouro, leito reservado para o Pré-Metrô.

Nos dois anos de coleta de informações sobre o valor da terra, 1973 e 1980, com exceção das áreas do Maracanã, Maria da Graça e Del Castilho, as demais localidades experimentaram desvalorização variando de 1,5\% a 58\%, com especial atenção para Acari, Pavuna e Engenho da Rainha. Talvez seja possível atribuir parte da desvalorização imobiliária na região a inconvenientes relativos às obras do Pré-Metrô, pois quando, em 1979-1980, as obras foram paralisadas, foram muitos os incômodos resultantes de vias, calçadas e praças destruídas ao longo de todo o trecho, como atestam vários artigos nos jornais O Globo e Jornal do Brasil. Parte da desvalorização pode ser atribuída ao conjunto de invasões e ocupações que se sucederam e que hoje se constituem nos enormes loteamentos irregulares e grandes extensões contínuas de favelas da região, onde se destacam algumas poucas áreas comerciais e de serviços, pequenos centros dos bairros antigos que abrigam uma população de renda média e média baixa. Exceção se dá no shopping Nova América, que na década de 1990 utilizou antigas instalações têxteis em Del Castilho, e no campus da Universidade Estácio de Sá. 
O crescimento de favelas e loteamentos irregulares na região em estudo se destaca no final da década de 1970 e na década de 1980, tanto pelo aumento de densidade nas favelas já existentes como pelo surgimento de novos assentamentos em várias glebas desocupadas quando do início da implantação do pré-Metrô. A expansão periférica de favelas se esgota no final dos anos 1970; nas palavras de Luis Cesar de Queiroz Ribeiro e de Luciana Corrêa do Lago no estudo A Oposição Favela-Bairro no Espaço Social do Rio de Janeiro ${ }^{27}$ :

[...] a queda na taxa de crescimento da população favelada entre as décadas de 60 e 70 foi a "abertura" da periferia metropolitana aos trabalhadores pobres por meio da produção extensiva de lotes urbanos, iniciada na década de 50 e expandida até os anos 70.

Desta forma, podemos concluir que a modesta valorização imobiliária ao longo da linha 1 do Metrô no período que vai da decisão de se construir o Metrô até o início dos anos 1980, recorte temporal deste trabalho de pesquisa, foi rapidamente assimilada pelo empresariado, e sem grandes pressões e confrontações com o poder público no que se refere às exigências fixadas quanto à ocupação dos terrenos e altura das edificações. A área de atuação dos incorporadores mais dinâmicos esteve durante todo o tempo de construção do trecho prioritário do Metrô localizada em outras áreas da cidade, que apresentavam oportunidades de ganho muito superiores às das áreas centrais, conforme relatado anteriormente. Para uma análise mais extensiva do mercado imobiliário formal e informal são de especial interesse as observações de Pedro Abramo

\footnotetext{
${ }^{27}$ A partir dos anos 1970, o crescimento extensivo de novos assentamentos entrou em colapso em função do encarecimento da terra, perda de capacidade de endividamento e transformações nas políticas de reconhecimento das favelas e loteamentos irregulares e clandestinos como solução dos problemas de moradia das camadas populares. Destaque-se que nos anos 1990 o ritmo de crescimento da população favelada manteve-se bem acima da proporção da população não-favelada. Nos subúrbios, em 1996, a proporção de população favelada sobre a população total dos subúrbios é de $21,8 \%$, muito superior à proporção da população favelada total sobre a população total do município, 17,2\%, na mesma data. Ver RIBEIRO, L. C. de Q.; LAGO, L. C. A Oposição Favela-Bairro no Espaço Social do Rio de Janeiro. Fundação SEADE, 2007. [16 p.] Disponível em:

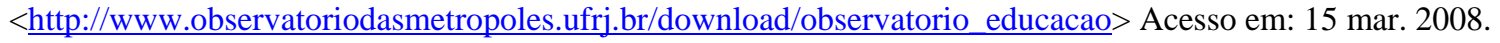


em Mercado e Ordem Urbana: do Caos à Teoria da Localização Residencial ${ }^{28}$. No que se refere à ligação rodoviária para a Barra da Tijuca, pode-se perceber um posicionamento do setor empresarial muito mais agressivo junto ao poder público na obtenção de melhorias de acessibilidade que proporcionassem uma valorização ainda maior para seus empreendimentos.

Com relação à atuação da Companhia do Metrô-RJ como empreendedora imobiliária nos remanescentes de terrenos desapropriados, seria de se esperar protestos veementes por parte do empresariado imobiliário contra a ação do Estado num domínio tradicionalmente seu. No entanto, poucos foram os empresários que se manifestaram contra essa idéia ${ }^{29}$ e nem mesmo sua principal entidade de classe, a ADEMI, se posicionou de maneira contrária.

\section{Setor Secundário em Geral}

Conforme mencionado anteriormente, enquanto produtoras dos transportes urbanos - construção civil, material rodante, equipamentos e sistema de automação - poucas empresas tinham sede no Rio de Janeiro; a maior parte das empresas que participaram do processo de implantação do MetrôRJ estavam localizadas em São Paulo. O setor secundário sediado no Rio de Janeiro estava orientado para outras áreas de produção, principalmente para a indústria siderúrgica e naval. Organizado através de associação de classe - a Federação das Indústrias do Rio de Janeiro -

\footnotetext{
${ }^{28}$ ABRAMO, P. Mercado e Ordem Urbana: do Caos à Teoria da Localização Residencial. Bertrand Brasil, 2007. 224 p.

${ }^{29}$ Observou-se, no período de 5 anos pesquisado na imprensa (1977 a 1982), apenas o editorial do Jornal do Brasil de 17 out. 1978 aconselhando o Metrô-RJ a andar mais depressa e deixar a cidade a quem tem o papel de produtor imobiliário e também a declaração de um diretor da Patrimóvel - Consultoria Imobiliária Ltda., Paulo Azambuja, afirmando ser perigoso o setor público interferir numa área em que o setor privado atende adequadamente, Jornal do Brasil de 18/10/1978. Ainda, nessa entrevista a Patrimóvel reconhece que seria interessante a atuação do mercado imobiliário nos bairros da Zona Norte atravessados pelo Metrô-RJ.
} 
FIRJAN - o setor não se posicionou especificamente pela implantação do empreendimento. Nas palavras de Mario Leão Ludolf ${ }^{30}$, representante da FIRJAN no Conselho Consultivo do Metrô-RJ:

[...] Os industriais eram, em geral, favoráveis à idéia do Metrô-RJ. Este melhoraria os deslocamentos da cidade e não lhes atrapalharia durante as obras, pois a indústria está na sua maior parte localizada alhures. Queriam a realização das obras, já atrasada 50 anos, mas não tiveram qualquer participação nas decisões tomadas quanto ao empreendimento.[...]

Mesmo interessados no menor custo da mobilização de sua força de trabalho, não chegaram a exercer pressões que pudessem resultar na implantação de novos sistemas de deslocamentos urbanos e nem mesmo na melhoria de trens e ônibus. Também não se observava no Rio de Janeiro, à época, ações significativas para fretamento de ônibus para transporte de funcionários, como já acontecia em São Paulo.

Na visão da FIRJAN, a indústria tradicional não tinha influência nas decisões para a implantação de grandes empreendimentos de transportes urbanos; é o segmento da construção civil que tem poder de negociação com o governo e o principal exemplo foi a entrada da Construtora Mendes Junior nas obras que efetivamente deu impulso às obras do Metrô-RJ.

\section{Setor Terciário em Geral}

À época de análise deste estudo, o setor de comércio e serviços da cidade do Rio de Janeiro atendia às necessidades de sua população, além de ser um centro de referência que incluía a população de todo o Estado do Rio de Janeiro e, em alguns aspectos, constituía-se num centro de referência nacional, em função de ter desempenhado por muito tempo o papel de capital do país.

\footnotetext{
${ }^{30}$ Mario Leão Ludolf - Representante da FIRJAN - Federação das Indústrias do Estado do Rio de Janeiro no Conselho Consultivo da Companhia do Metrô-RJ - entrevista em 15/02/82. Conhecedor do posicionamento das indústrias cariocas e fluminenses nos diversos segmentos da produção industrial.
} 
Os comerciantes estavam organizados em uma associação de classe muito atuante, a Associação Comercial do Rio de Janeiro, formadora de opinião em diversos assuntos de interesse de seus associados e com fortes relações na administração pública. Embora com grande capacidade de penetração na sociedade carioca, a Associação Comercial praticamente não se manifestou sobre a pertinência da implantação de um sistema de Metrô na cidade. A Revista da Associação Comercial editada mensalmente pela Confederação das Associações Comerciais do Brasil, Federação das Associações Comerciais Industriais e Agropastoris do Estado do Rio de janeiro e Associação Comercial do Rio de Janeiro, no período que vai de 1965 a 1980, não deu destaque ao empreendimento, trazendo matérias sobre o Metrô apenas em cerca de 14 números, num total de 192 revistas editadas. No período de 1965 a 1969, não houve nenhuma manifestação impressa sobre o Metrô; em seguida, até 1971, cinco artigos foram publicados contestando a sua necessidade. A partir de 1972 e até 1975, a Revista se posicionou contra a paralisação das obras em quatro artigos, sendo que no período mais intensivo de construção a Revista deu apoio ao empreendimento oferecendo espaço para a própria Companhia do Metrô se manifestar, voltando a criticar severamente a paralisação das obras no ano de 1980 nos cinco artigos subsequentes.

Em entrevista com Décio Burlamaqui, membro do Conselho Diretor da Associação Comercial do Rio de Janeiro ${ }^{31}$, este afirmou que no início do processo de implantação do Metrô-RJ, os comerciantes não enxergavam as vantagens de um sistema de transporte de massa especificamente para sua atividade. Informalmente se posicionavam com alguma simpatia ao empreendimento enxergando o sistema como uma intervenção que poderia melhorar a situação

\footnotetext{
${ }^{31}$ Décio Burlamaqui - Membro do Conselho Diretor da ACRJ - Associação Comercial do Estado do Rio de Janeiro - entrevista em 19 jan. 1981. Representante da ACRJ no Conselho Consultivo da Companhia do Metrô-RJ por nove anos.
} 
de deslocamentos em geral no Rio de Janeiro, o que evidentemente melhoraria as atividades de comércio e serviços, mas sem outras justificativas mais específicas.

No entanto, durante a execução das obras, os comerciantes foram fortemente prejudicados. Parte dos comerciantes, mais especificamente o segmento dos lojistas ${ }^{32}$, foi bastante ativo nas suas reivindicações junto à Companhia do Metrô-RJ, no entanto, isso só ocorreu depois que as obras já estavam em andamento, movidos pelos desconfortos que elas geravam. Chegaram mesmo a questionar a questão do traçado na rua Uruguaiana (nas regiões mais densas em comércio).

Alertavam para as perdas financeiras advindas dos inconvenientes com as obras e tentavam influenciar no andamento das obras, em especial no fechamento de galerias e reurbanização, numa atitude de proteção de seus interesses tentando diminuir as perdas e as falências que foram muitas.

Essa pressão era feita através da grande imprensa em geral e numa atitude de colaboração com o poder público. Os líderes dessas movimentações acreditavam que se conseguissem suportar os inconvenientes dessa fase inicial - a construção -, as melhorias com a reurbanização e com o aumento de acessibilidade iriam beneficiar o comércio em geral. Essa era especialmente a posição dos comerciantes das áreas centrais, locais que experimentavam uma fase de decadência e que efetivamente foram revitalizados com a conclusão das obras.

Nesse período, a Assessoria de Comunicação da Companhia do Metrô-RJ se empenhou em prestar esclarecimentos visitando a Associação Comercial e o Clube dos Lojistas em várias

\footnotetext{
${ }^{32}$ Segundo informações de Silvio Cunha - Presidente do Clube de Diretores de Lojistas do Rio de Janeiro - em entrevista realizada em 26 jan. 1982.
} 
ocasiões, promovendo debates. Tentando diminuir a pressões, a própria Associação Comercial, através de seu representante no Conselho Consultivo do Metrô-RJ, passou a prestar esclarecimentos junto a seus associados sobre o andamento das obras e especialmente sobre a valorização que o Metrô-RJ traria aos seus pontos de comércio ${ }^{33}$.

Resumindo, embora os lojistas não tenham se posicionados no início do empreendimento, eles foram bastante atuantes nas suas reivindicações durante a obra, tentando apressar o final das mesmas, tendo em vista que passaram a ser muito prejudicados. Pode-se concluir que os comerciantes e prestadores de serviços em geral não exerceram nenhuma influência na tomada de decisão para a implantação do empreendimento. Só se posicionaram quando foram diretamente atingidos. Não se manifestaram com relação aos possíveis ganhos na mobilização da sua força de trabalho, e nem sobre as grandes vantagens de aumento de acessibilidade para seus clientes em geral.

\section{A população - motorizada e cativa do transporte público}

A população em geral está sempre interessada nas melhorias dos sistemas de transportes. No entanto, no Rio de Janeiro, à época da decisão de se construir o metrô, eram poucos os canais de expressão e participação da população. Praticamente não existiam associações de bairros, com exceção de algumas poucas associações de favelas. A representatividade parlamentar não era considerada pela população um canal legítimo de participação nos assuntos da cidade. Nesse contexto, a grande imprensa desempenhava um papel que ultrapassava em muito a fronteira da informação, passando à crítica e à denúncia, em substituição à ausência de participação popular organizada.

\footnotetext{
${ }^{33}$ Entrevista de Décio Burlamaqui anteriormente citada.
} 
Segundo Francisco Viana ${ }^{34}$, articulista de “O Globo”, as seções referentes às matérias locais eram muito destacadas e eram onde se alocavam os melhores jornalistas. No período de decisões e especialmente no período de construção, o Metrô ocupou um espaço praticamente diário nesses veículos. Somente quando as associações de moradores de bairros começaram a se formar é que o espaço da imprensa, informando e discutindo a relação da população com o Metrô, diminuiu. De maneira geral, o Jornal do Brasil se posicionou contra a implantação de um sistema de transporte subterrâneo para a cidade, pois considerava que existiam outras formas, mais baratas e adequadas à cidade, para melhorar as condições de deslocamento. Os editoriais dos anos 1967 a 1970 confirmam esse posicionamento e refletiam o pensamento de oposição às definições políticas pós 1964, nas quais o Metrô-RJ se inseria. O jornal “O Globo”, por sua vez, apresentava uma posição mais favorável ao Governo Federal e embora dirigisse suas matérias numa linha menos agressiva com relação ao Metrô, também não demonstrava grande aceitação.

A população, motorizada ou cativa, efetivamente só se expressou e se mobilizou quando as obras começaram a interferir com sua rotina causando transtornos significativos. No entanto, as pessoas se aglutinaram em grupos identificáveis e que se manifestaram, constituíram grupos restritos e territorialmente localizados em função da presença da obra, como por exemplo os moradores da Tijuca e os moradores do Botafogo. Ao se sentirem de certa forma prejudicados com as obras, moradores se organizaram e se posicionaram pela urgência na finalização dos serviços, em especial nos momentos de paralisação, quando o horizonte de finalização parecia incerto.

\footnotetext{
${ }^{34}$ Francisco Viana - Editorialista de O Globo - entrevista em 25 fev. 1982. Foram recolhidas informações sobre o papel da imprensa nos momentos de decisão também a partir de entrevistas com Alberto Dines - Editorialista do Jornal do Brasil e do Pasquim - entrevista em 08 mar. 1982 e Wilson Figueiredo - Editorialista do Jornal do Brasil entrevista em 11 mar. 1982.
} 
Um ponto positivo a se considerar, quanto à capacidade de organização social, foi a contribuição das obras do Metrô como um dos fatores para o surgimento de associações de moradores em vários bairros do Rio de Janeiro, muitas delas com finalidade específica de pressionar por melhores condições das obras - seja para diminuir os inconvenientes durante sua realização, seja pela sua finalização - e que permaneceram em atividade depois dos momentos críticos do MetrôRJ, reunidos em torno de interesses comuns. De maneira geral, quando as obras de reurbanização foram sendo finalizadas, especialmente na Tijuca, que muito sofreu com a paralisação das obras, a visão da população sobre o Metrô-RJ tomou um rumo positivo, quando os inconvenientes de superfície foram superados.

Com a inauguração do empreendimento, aos poucos a visão sobre o Metrô foi se modificando, embora por falta de planejamento integrado dos transportes as linhas tenham ficado ociosas por muitos anos. Nas palavras de Francisco Viana: “Se antes não se tinha organização para se lutar contra a obra ou contra a maneira como ela estava sendo feita, quando as organizações populares surgiram, elas começaram a atuar para apressar a obra.”

Somente muito recentemente, com a concessão dos serviços para a iniciativa privada em 1998, que trabalhou severamente no sentido de aumentar a demanda pelos seus serviços - estabeleceu linhas de integração com ônibus em várias estações - de forma a otimizar o uso do sistema, é que a população passou a ter uma visão não negativa e perceber a importância do sistema.

Adicionalmente, a questão das desapropriações, também uma questão localizada, se transformou em interesse coletivo, uma vez que, ao desapropriar áreas a maior para a implantação do empreendimento, resultaram terrenos remanescentes que foram insistentemente requisitados por 
alguns grupos de moradores para a implantação de equipamentos sociais, considerados insuficientes.

Jó Rezende ${ }^{35}$, que à época era o presidente da recém criada Federação das Associações de Moradores do Estado do Rio de Janeiro - FAMERJ, afirmou que as associações se fortaleceram nas discussões sobre o destino das áreas desapropriadas quando passaram a participar ativamente da Câmara Técnica que funcionou durante o segundo semestre de 1980, formada especificamente para encaminhar essa questão.

Embora sempre interessada na melhoria das condições de deslocamento na cidade, o comportamento da população enquanto motorizada e enquanto cativa dos sistemas de transportes públicos tende a ser distinto.

Como destacado no Capítulo 2, a população motorizada almeja melhorias no sistema viário, facilitando sua circulação, e espera que os custos sejam absorvidos por toda a comunidade na forma de produção da infra-estrutura - vias (novas ou alargamentos), viadutos, túneis etc. Esse grupo não apresenta formas específicas de representatividade e de manifestação, estando sua opinião expressa enquanto indivíduos pertencentes a outros grupos de interesse e neste papel, sim, têm alta representatividade ao, indiretamente, se posicionar a favor de expansões do sistema viário para a circulação de automóveis. Efetivamente, não se observou, em todo o material pesquisado - todos os jornais de grande circulação da cidade no período em tela - a formação de grupos organizados que se posicionassem contra o Metrô-RJ e outras formas de transporte

\footnotetext{
35 Jó Resende - Presidente da FAMERJ - Federação das Associações de Moradores do Estado do Rio de Janeiro entrevista em 04 mar. 1982. Foi prefeito do município do Rio de Janeiro no período de 1988 a 1989.
} 
coletivo e a favor do transporte individual, bem como não se observou na Câmara de Vereadores qualquer posicionamento relativamente a essas questões.

A população cativa do transporte público almeja melhorias no sistema de transporte coletivo em geral e suas demandas se concentram principalmente na manutenção ou diminuição do preço das passagens, na ampliação das linhas e abrangência dos sistemas e nas demandas por melhorias de serviços, freqüência etc. Da mesma forma que a população motorizada, não foram observadas manifestações em todo o material pesquisado. O poder de mobilização dessa população era muito restrito, não tendo sido observada a formação de grupos ou associações que pudessem lutar por transporte público. Junto à Câmara de Vereadores, por vezes os interesses da população cativa podem fazer parte da agenda de vereadores, mas também essa prática não pôde ser observada. Em situações de crise, podem ocorrer manifestações, como várias vezes aconteceram na cidade nas lutas por melhorias nos trens de subúrbio ou nas denúncias dos serviços de lotações; mas, não foi observada qualquer manifestação direta da população cativa, no sentido da necessidade da implantação de um sistema de transportes do tipo Metrô.

Assim, pode-se afirmar que a população de maneira geral não exerceu influência perceptível na decisão maior de se construir o Metrô-RJ, nem na linha central nem na linha 2, para os subúrbios na direção da Pavuna. Na opinião de Carlos Nelson dos Santos ${ }^{36}$, o Metrô era uma imposição para a população do Rio de Janeiro que não queria esse empreendimento. No entanto, segundo ele, a sociedade carioca é extremamente contraditória e passou a se orgulhar do Metrô quando o mesmo foi inaugurado.

\footnotetext{
${ }^{36}$ Carlos Nelson dos Santos - Pesquisador do Centro de Pesquisas Urbanas do IBAM - Instituto Brasileiro de Administração Municipal - entrevista em 09 mar. 1982. Sociólogo, observador independente dos assuntos urbanos da região.
} 


\subsection{Os Gestores dos Transportes Urbanos}

Podemos distinguir dois aspectos importantes na gestão dos grandes empreendimentos urbanos do setor de transportes. O primeiro, mais geral, se refere ao universo político-econômico onde as ações têm lugar, sendo reguladas por intenções mais amplas e gerais das políticas e das condições econômicas e dos interesses de cada esfera de governo. O segundo, mais particular, se refere à organização das instituições públicas diretamente ligadas à gestão dos sistemas específicos, onde se distingue o papel da burocracia técnica do governo.

O aspecto mais geral das condições político-econômicas pode chegar a ter uma influência muito forte nas decisões de intervenções específicas, já que definem uma orientação geral para as tomadas de decisão, sendo portanto determinantes a nível macro.

A burocracia do governo pode constituir-se num vetor de pressão e influência nas decisões também especialmente forte, seja amparada por justificativas essencialmente técnicas - enquanto detentora de conhecimento no âmbito dos transportes, como executora ou contratante de estudos, planos etc. -, seja enquanto possível representante velado do interesse de grupos econômicos específicos, que através dela conseguem uma “porta de entrada” na administração pública. Não se constitui num grupo homogêneo, apresentando-se em diversas frações representando interesses distintos e dominando técnicas concorrentes.

As decisões resultantes das ações tanto do meio político quanto da burocracia técnica refletem o momento histórico de organização das instituições. Num momento de forte centralização de decisões, como nos anos pós 1964, a tendência do meio político e dos gestores das instituições 
públicas é de favorecer o subsistema produção em geral - oferta - e em especial a produção dos transportes em detrimento das reivindicações do subsistema consumo - demanda.

\section{O meio Político}

Pode-se perceber que o agente de maior importância para a decisão, aprovação do projeto e implantação do sistema foi a administração de Negrão de Lima. Durante sua gestão como Prefeito do Distrito Federal (1956 a 1958), a Companhia do Metropolitano do Rio de Janeiro chegou a ter uma atuação importante e, embora tenha sido extinta em 1961 pelo governador Carlos Lacerda, foi novamente constituída em 1968, na gestão de Negrão de Lima como governador do Estado da Guanabara (1965 a 1970). Foi efetivamente na sua administração à frente do estado que os passos mais decisivos foram feitos ${ }^{37}$ para que a decisão fosse tomada, a partir do Estudo de Viabilidade contratado e concluído em 1968, e ainda nos dois anos seguintes foram elaborados os projetos executivos e iniciadas as desapropriações.

Já a partir de 1970, durante a gestão Chagas Freitas, a implantação do Metrô avançou lentamente, vindo a ser efetivamente retomada com grande fôlego na gestão do Almirante Faria Lima, primeiro governador do Estado do Rio de Janeiro - $1^{\circ}$. Governo da Fusão. Quando novamente Chagas Freitas assumiu o governo do estado, desta vez do Estado do Rio de Janeiro, as obras prosseguiram muito lentamente, podendo-se afirmar que, além da justificativa da recessão econômica, o Metrô não era um projeto de governo para Chagas Freitas.

\footnotetext{
${ }^{37}$ Muitas vezes Negrão de Lima declarou que seu principal interesse na gestão do Estado da Guanabara era saneamento e não o Metrô, mas que se o Governo Federal estivesse disposto a colaborar financeiramente, teria disposição em trabalhar na sua realização, segundo informações de Josef Barat - Secretario dos Transportes do Estado do Rio de Janeiro 1975 a 1978 - entrevistas em 25/ mar. 1981, 03 abr. 1981, 06 abr. 1981 e 08 abr. 1981.
} 
Negrão de Lima esteve alinhado com uma visão desenvolvimentista com relação à região. No entanto, sua gestão não apresentou um alinhamento com os representantes do Governo Federal constituídos através do golpe militar de 1964, pois foi eleito por uma coligação de partidos de oposição ao governo federal ${ }^{38}$, mas se contrapôs fortemente às políticas clientelistas e às idéias do grupo lacerdista. Não era o nome que os militares apoiavam para o governo da Guanabara. A criação da Companhia do Metrô-RJ em 1968 corresponde aos esforços de imprimir maior dinamismo ao aparelho do estado possibilitado pelo Decreto-Lei no. 200 de 1967 e mesmo a partir da criação da CEPE-2, anteriormente à Companhia do Metrô-RJ; foi possível efetivamente agir de forma mais eficiente e com um objetivo claro de administração pública. A grande concentração de formulação e apresentação de idéias por parte de muitos engenheiros especialistas no ano de 1962, e que foi rechaçada por Carlos Lacerda, que preferiu um outro caminho para a cidade com relação aos transportes urbanos, fortaleceu as decisões da gestão seguinte - de Negrão de Lima.

Chagas Freitas, por sua vez, é considerado como a representação das forças locais mais arraigadas e como afirmado por Ana Maria Brasileiro, com uma atuação clientelista, característica ainda do Estado Patrimonialista $^{39}$. Nas duas vezes em que esteve à frente do Governo do Estado, seja da Guanabara, seja do Rio de Janeiro, as decisões tomadas com relação

\footnotetext{
${ }^{38}$ A eleição de Negrão de Lima no Rio de Janeiro e de Israel Pinheiro em Minas Gerais à frente de partidos de oposição ao governo federal precipitou a edição do AI-2 que acabou com o pluripartidarismo no país.

${ }^{39}$ Chagas Freitas foi deputado federal por quatro vezes e embora tenha apoiado ativamente o movimento militar de 1964, filiou-se ao partido de oposição MDB pois a Arena estava sob controle dos lacerdistas. Foi mentor de uma política clientelista (numa relação direta entre cargos e cabos eleitorais), conhecida como “chaguismo”. Em 1970, foi eleito governador da Guanabara, por via indireta, e buscou não hostilizar o governo militar. Não fez seu sucessor para o primeiro Governo da Fusão, mas voltou em 1979. Segundo PINHEIRO, T. De Chagas Freitas a Anthony Garotinho (ou) Do clientelismo ao assistencialismo. Portal Imprensa 09/12/2204. Disponível em:

<http://portalimprensa.uol.com.br/portal/foca_online/2004/12/09/imprensa2691.shtml> Acesso em: 29 out. 2008, da Universidade Estácio de Sá, Chagas Freitas lapidou e deu uma forma única ao esquema clientelista e assistencialista de fazer política no Rio de Janeiro.
} 
ao Metrô-RJ, se não puderam ser canceladas devido a compromissos formalmente assumidos, também não tiveram um prosseguimento no sentido de sua realização, sendo as obras praticamente paralisadas na sua segunda gestão.

Tanto Negrão de Lima quanto Faria Lima conseguiram dar início e prosseguimento, respectivamente, à implantação do Metrô, e seguiram as orientações mais gerais de inserir na administração pública estadual uma estrutura que possibilitasse um desempenho voltado às realizações do modelo desenvolvimentista, iniciado com as primeiras ações da reforma burocrática mas que só muito lentamente conseguiu se implantar no país e de maneira descontínua e muitas vezes com características de grande peso processual. Foi efetivamente a montagem da Companhia do Metrô-RJ num modelo de administração indireta com maior autonomia que possibilitou grande parte das ações. Retirou das elites locais grande parte de sua influência, mas por outro lado, reforçou o poder da administração federal, pós 1964. Puderam ser observadas as orientações de política pública mais gerais, com relação às questões urbanas e aos transportes urbanos que começaram a se configurar no início dos anos 1970, com os trabalhos do IPEA, dentro do Ministério do Planejamento, com a criação das Regiões Metropolitanas, da CNDU e dos Fundos Nacionais de Desenvolvimento Urbano e dos Transportes Urbanos em 1974 e da EBTU em 1975.

Wilson Quintella, baseado na experiência da Camargo Corrêa, afirma que os 20 anos que vão de 1964-1984 foi um período de cliente único - o Governo Federal. E ainda que se, à época do presidente Juscelino Kubitschek, para que as obras avançassem, era o próprio presidente que 
tomava decisões até mesmo de canteiro de obras ${ }^{40}$, à época dos governos militares, a idéia da administração era imprimir uma feição mais séria, correta e eficiente aos atos administrativos ${ }^{41}$, mas que, mesmo com essa orientação, decisões sobre quais obras e o andamento delas eram decididos pelos presidentes. Cita detalhadamente o caso da ponte Rio-Niterói que, sob determinação do presidente Médici, foi construída sob presença no canteiro e gerência direta do Ministro dos Transportes, Mário Andreazza.

No caso do Metrô-RJ, os depoimentos do engenheiro Carlos Jorge, funcionário de destaque da Cia do Metrô-RJ, de Bruno Costa Soares - Diretor Financeiro da Companhia da gestão Noel de Almeida (1975-1980) ${ }^{42}$, era o Governo Federal que decidia a estratégia para as concorrências, definindo se as empresas a trabalharem no Metrô-RJ seriam nacionais e/ou estrangeiras, sob a responsabilidade de quantos prestadores de serviços a obra deveria estar, aditivos, participação relativa nos investimentos das três instâncias governamentais e tipos de empréstimos. Segundo

\footnotetext{
${ }^{40}$ Transcrição da página 165 de QUINTELLA, W. Memórias do Brasil Grande: a história das maiores obras do país e dos homens que a fizeram. São Paulo: Editora Saraiva, 2008. 426 p, sobre a construção de Brasília: [...]Ele (Juscelino) atropelou a lerda burocracia estatal, que simplesmente não teve chance de interferir no ritmo das obras, pois JK acompanhava e decidia tudo pessoalmente. Isso era algo que não estávamos acostumados a ver em obras públicas. Mais ainda: os pagamentos eram feitos em dia, sem qualquer protelação.[...]

${ }^{41}$ Cabe observar que a administração do Presidente Castelo Branco - na pessoa de seu Ministro do Planejamento, Roberto Campos - imprimiu uma feição modernizadora à atuação federal ao introduzir junto aos ministérios, organismos que pudessem alterar o modo de funcionamento da burocracia estatal. Destacam-se o GEIPOT no Ministério dos Transportes, o reforço de gestão em instituições como a Eletrobrás e suas subsidiárias, junto ao Ministério de Minas e Energia e o IPEA junto ao Ministério do Planejamento. Já no governo do Presidente Costa e Silva, as orientações de planejamento ficaram esvaziadas e voltaram a se fortalecer os organismos de implantação de obras e operação de sistemas como o DNER e a RFFSA. O DNER, no entanto, afeto às orientações dos organismos financiadores internacionais que exigiam mudanças no comportamento de gestão das instituições e tendo assimilado alguns conceitos modernizadores do GEIPOT passou a ter uma atuação mais racional e orientada para resultados, diferentemente da RFFSA que, com pouca capacidade de investimento e ainda persistente nas práticas de predominância patrimonialista, vai se deteriorando e sofre uma grande intervenção em 1975, após acidente de grandes proporções nos subúrbios do Rio de Janeiro.

${ }^{42}$ Entrevistas com Carlos Jorge - Engenheiro da Companhia do Metrô-RJ e Bruno Costa Soares - Diretor Financeiro e Administrativo da Companhia do Metrô-RJ durante o Governo da Fusão, respectivamente em 12 mar. 1982 e 18 fev. 1982.
} 
Jorge Guilherme Francisconi ${ }^{43}$, presidente da EBTU - Empresa Brasileira de Transportes Urbanos, os recursos a serem alocados para o Metrô-RJ eram decisões diretas de compromissos entre o presidente Ernesto Geisel e do presidente da Companhia do Metrô-RJ, Noel de Almeida.

\section{A Burocracia Técnica}

Para a realização do empreendimento, reproduziu-se no nível estadual a estrutura técnica burocrática que havia sido montada no Governo Federal para a realização das obras concebidas pelos governos militares.

O Governo da Fusão foi liderado pelo Almirante Faria Lima, indicado por Brasília, como braço federal no Estado, com o objetivo de consolidar a fusão, não abrindo oportunidades para qualquer discussão ou questionamento por parte da sociedade local sobre essa questão.

Da mesma forma que na esfera federal, a idéia de se modernizar a administração pública estadual atribuiu à Companhia do Metrô-RJ o papel de indutor de transformações nos demais sistemas de transportes urbanos. Assim, o Grupo de Trabalho responsável pelas diretrizes organizacionais da fusão dos dois estados estabeleceu que, nesse setor, eram imperativas as seguintes medidas: a transferência do sistema ferroviário urbano (subúrbios) e do sistema hidroviário da esfera federal para a estadual; avanços em engenharia de tráfego para o sistema de ônibus e o aumento da capacidade executiva e de planejamento da Companhia do Metrô-RJ, de forma que esta teria o

\footnotetext{
${ }^{43}$ Entrevista com Jorge Guilherme Francisconi - Presidente da EBTU - Empresa Brasileira dos Transportes Urbanos, em 23 jul. 1981 e 24 jul. 1981. Arquiteto e administrador público, responsável pela política nacional de transportes urbanos, aí incluídos os Metrôs do Rio de Janeiro e de São Paulo à época do Governo da Fusão.
} 
papel de dotar o novo estado de um sistema de planejamento e de integração dos transportes urbanos na região metropolitana.

Desta forma, a Companhia do Metrô-RJ foi organizada durante o Governo da Fusão com integrantes que reproduziam o modo de pensar federal. O presidente da companhia foi escolhido pelo presidente Ernesto Geisel, com quem tinha uma relação muito próxima oriunda da atuação de ambos na Petrobrás. Foram contratados profissionais de alta competência técnica, comprometidos com o propósito da realização, que acreditavam na pertinência da obra, e que se destacavam pela capacidade de não se influenciar por interesses contrários ao empreendimento, mesmo que muitos desses dirigentes fossem originários da elite local. Segundo depoimento de Jorge Guilherme Francisconi, os técnicos do Metrô-RJ constituíam-se numa elite intelectual, que respondia também às demandas técnicas da Secretaria de Transportes, relativas a outros modos de transportes ${ }^{44}$. Essa equipe não teve permanência quando os recursos financeiros começaram a escassear. Diferentemente da Companhia do Metrô-SP, o Metrô-RJ não investiu na formação profissional dos técnicos que permaneceriam, de forma que houve um esvaziamento de competência nas administrações seguintes.

Pode-se observar a presença de alguns técnicos durante grande parte do processo de maturação da idéia do Metrô-RJ, dentre eles destacam-se os engenheiros Jorge Schnoor, Fernando Lavrador e Francisco Ebling, que apresentaram vários estudos e estiveram presentes dentro da administração e fora dela, não permitindo que a idéia morresse; inicialmente ligada às melhorias e ampliação do transporte ferroviário em geral e posteriormente na defesa do Metrô-RJ como empreendimento

\footnotetext{
${ }^{44}$ O projeto de melhorias da avenida Brasil, de modificação do sistema de ônibus, incluindo vias seletivas, de áreas exclusivas para pedestres previsto pelo Grupo de Trabalho da Fusão foi desenvolvido pela Companhia do Metrô-RJ, fora de suas atribuições principais.
} 
isolado. Além desses, muitos outros engenheiros ferroviários defendiam a implantação do sistema ao apresentarem um conjunto numeroso de estudos através do Clube de Engenharia. Assim, embora esses engenheiros não tenham sido os agentes de decisão efetivos, tanto na decisão de se construir quanto durante o período de maior atividade da Companhia, certamente esse grupo contribuiu para a cristalização da idéia, de forma que ela estivesse amadurecida quando o Governo Federal procurou uma obra que pudesse satisfazer a cidade e ajudasse a conseguir aceitação pública na difícil tarefa de implantar a fusão administrativa dos dois estados.

Certamente a organização da Companhia do Metrô-RJ, no período de maior atividade na implantação do sistema, já fazia parte do movimento que se iniciava com o Decreto-Lei no. 200/1967 de imprimir um caráter mais profissional e de comprometimento com resultados, portanto gerencial, aos quadros da administração indireta. Seu corpo técnico era muito mais qualificado e recebia melhores salários do que seus correspondentes na administração direta ${ }^{45}$. A empresa tinha autonomia financeira e menores controles burocráticos e respondia a uma orientação de política pública gestada de comum acordo entre os agentes públicos do estado e da União. Nesse sentido, o corpo técnico teve autonomia para dar diretrizes ou efetivamente projetar e especificar aquilo que julgou adequado para a implantação do sistema naquele momento, sem que pressões dos produtores dos materiais e equipamentos pudessem interferir na sua capacidade de decisão. Não estava, no entanto, orientada por uma visão de cidadão-cliente, e respondia à antiga visão da oferta para as grandes obras de infra-estrutura, onde o Estado era o principal provedor.

\footnotetext{
${ }^{45}$ Os técnicos preteridos dentro dessa organização modernizadora chegaram a se manifestar com críticas à implantação do Metrô, cujos recursos seriam melhor utilizados em sistema viário, especialmente viadutos e nas linhas ferroviárias de subúrbios.
} 
Adicionalmente, ao integrar no Conselho Consultivo da Companhia do Metrô-RJ representantes de setores produtivos locais que poderiam obstar suas atividades, como os segmentos industriais e do comércio, a empresa soube construir alianças, sem as quais sua tarefa de implantação do sistema poderia ter tido dificuldades ainda maiores. 
CAPÍTULO 08 


\section{A REDE DA DECISÃO - CONCLUSÕES}

O estudo detalhado das condições de concepção e de implantação do Metrô do Rio de Janeiro nos proporciona algumas indicações sobre o processo de decisão na cidade do Rio de Janeiro e nas grandes cidades brasileiras no que se refere a investimentos em transportes urbanos no período de vinte anos que se inicia nos anos 1960.

A partir da confrontação dos possíveis comportamentos dos atores presentes no processo de decisão e implantação da obra com as informações levantadas, pode-se afirmar que o MetrôRJ foi uma realização do Governo Federal. No entanto, a União não foi o único agente na decisão de construí-lo, mas foi o mais importante e o aglutinador dos interesses em torno do empreendimento - alguns mais fortes do que outros -, mas todos significativos na formação das alianças entre agentes.

A construção do Metrô-RJ envolveu, até 1980, uma soma considerável de recursos (cerca de 1.500 milhões de dólares americanos, sem contar o custo da dívida financeira), a maior parte da qual disponibilizada pelo Governo Federal através de: aporte direto de capital (mediante participação acionária de 36,5\% no ano de 1981), aporte indireto através de transferências orçamentárias ao novo Estado do Rio de Janeiro e apoio indireto através das garantias da União para empréstimos no exterior.

Apesar da construção do Metrô ser uma idéia antiga para a cidade do Rio de Janeiro, os interesses locais não conseguiram se reunir de maneira a realizá-la, e foi somente no Governo da Fusão, 1975 a 1979, que o Metrô recebeu seu maior impulso e foi efetivamente construído. Recorde-se que o Governo da Fusão foi uma intervenção direta do Governo 
Federal na administração dos dois estados - Rio de Janeiro e Guanabara - reproduzindo o modelo de gestão do país pós 1964, alicerçado no reforço de poder à burocracia técnica. O objetivo oficial da fusão era uma reorganização de caráter territorial mais racional e a modernização da administração desse novo território. O motivo real, no entanto, segundo Ana Maria Brasileiro ${ }^{1}$, teria sido a intervenção federal na política de um estado - Guanabara -, tradicionalmente de oposição aos governos centrais pós 1964, de modo a enfraquecer, ou mesmo alterar radicalmente, a correlação de forças do seu sistema de poder. Sejam quais forem as verdadeiras razões para a intervenção da União, foi no Governo da Fusão que o Metrô foi efetivamente construído, sendo considerada a grande obra pública que caracterizou esse período de governo. O Grupo de Trabalho, estabelecido em 1974 pelo Governo Federal para oficialmente organizar o novo estado, diagnosticava o Metrô como necessidade prioritária para a solução dos transportes urbanos na cidade do Rio de Janeiro, elemento em torno do qual os demais modais de transportes poderiam ser modernizados, e ainda que o modelo de gestão da Companhia do Metrô-RJ se tornaria o centro propulsor de racionalidade e modernidade na administração do estado.

Dentro desse quadro mais geral, o Governo Federal proporcionava ao novo estado uma obra de impossível realização com recursos locais. Os destinos do Metrô-RJ já estavam sendo decididos a nível federal no início dos anos 1970, quando o Governo Federal permitiu e se propôs a avalizar os empréstimos externos para o empreendimento, sob a condição de intervir no traçado e características da rede, nas condições financeiras, nos índices de nacionalização da tecnologia empregada e no cronograma de sua realização, de acordo com a Exposição de Motivos $n^{0}$ 106/1970. Embora tenham existido algumas iniciativas locais de se iniciar a implantação do sistema, especialmente nas gestões de Negrão de Lima enquanto

\footnotetext{
${ }^{1}$ BRASILEIRO, A. M. A Fusão: Análise de uma Política Pública, IPEA. Série Estudos para o Planejamento, no. 21. Brasília, 1979. 364 p.
} 
prefeito da cidade e posteriormente enquanto governador do Estado da Guanabara, com a criação da Companhia e o início das atividades de projeto e, embora algum recurso financeiro tenha sido alocado para o Metrô-RJ no período de governo imediatamente anterior à fusão (no Governo Chagas Freitas - que esteve voltado para obras de cunho rodoviário), a construção do Metrô não deslanchou. Foi só com a intervenção direta do Governo Federal, através do governador nomeado para a implantação da fusão dos dois estados, que a obra avançou com rapidez.

Esse desenrolar de fatos nos mostra, primeiramente, que o vetor resultante das forças e interesses locais não apontava para a construção do Metrô-RJ e em segundo lugar, que $\underline{\text { a }}$ realização da obra foi imposta pela União. Quando nas eleições, mesmo que indiretas, para o período administrativo seguinte à Fusão, o Governo Federal saiu derrotado, é novamente Chagas Freitas, que representava as forças locais mais retrógradas da região, quem veio a assumir os destinos do Estado e a prioridade do Metrô foi repensada e perdeu a importância adquirida no Governo da Fusão.

Antes de aprofundar a discussão sobre quais razões levaram o Governo Federal a se decidir sobre o apoio ao Metrô-RJ, cabe buscar nos demais grupos de interesses quem poderia sair beneficiado com a implantação do empreendimento e se alguma forma de pressão ou influência pode ser identificada.

As hipóteses secundárias formuladas no capítulo 2 apontam para os seguintes grupos de interesse como os principais agentes na decisão de se idealizar e implantar o Metrô-RJ:

1. os grupos ligados à propriedade imobiliária (terra e construção), tendo em vista a estreita relação entre o aumento de acessibilidade e a valorização da propriedade; 
2. os grupos ligados à produção dos transportes, já que existe uma relação direta entre os investimentos públicos e seu volume de trabalho;

3. a população em geral, em função das possibilidades de manifestação por ações nos transportes urbanos e

4. a burocracia técnica do governo, em função do domínio técnico; grupo muitas vezes permeável aos assédios de grupos econômicos.

A partir da análise feita no capítulo 7 sobre o comportamento dos atores presentes no processo de decisão em transportes urbanos, e que discute a participação dos grandes grupos de interesse que fazem parte dos subsistemas produção, consumo e gestão no processo decisório do Metrô do Rio de Janeiro, pode-se afirmar que as hipóteses 1 e 3 não puderam ser demonstradas e que as hipóteses 2 e 4 se comprovam apenas parcialmente.

Desta forma, quanto à hipótese 1 , um dos setores que poderia se beneficiar indiretamente com a obra através da valorização de suas propriedades e que poderia ter influenciado o processo de decisões compõe-se dos proprietários de terras e os empresários imobiliários. Teoricamente, poder-se-ia esperar um empenho desses grupos nas melhorias efetivas no sistema de transportes gerando, automaticamente, uma mais-valia fundiária nas áreas direta ou indiretamente atendidas pelo novo sistema. Entretanto, no caso do Metrô-RJ, como vimos no capítulo anterior, não se evidenciaram pressões desses segmentos na decisão de se construir um Metrô; ao contrário, seus interesses estiveram dirigidos para as extensões e melhorias viárias direcionadas para o extremo da Zona Sul da cidade. Não foram observadas influências para definição de traçado em nenhuma das linhas projetadas e implantadas. Mesmo a reação desse empresariado foi de pequena magnitude quando a Companhia do 
Metrô-RJ decidiu atuar no mercado imobiliário, iniciativa que não pôde ser efetivamente realizada.

No que se refere à hipótese 2, com relação aos setores que diretamente participaram do fluxo financeiro gerado com a obra, foi a Construção Civil o item que mais consumiu recursos, chegando a 52\% do total nos períodos mais dinâmicos da obra. Na época, as empreiteiras brasileiras eram empresas de grande expressão financeira, geradoras de um volume significativo de empregos, inclusive com atuação no exterior, e que, como vimos, apresentavam muita proximidade com os principais agentes públicos de decisão em todas as esferas de governo, especialmente na esfera federal. Esses grupos teriam capacidade de conseguir recursos junto ao Governo Federal para uma possível obra que lhes interessasse, influenciando assim diretamente as decisões.

A obra do Metrô foi atribuída inicialmente a empresas de médio porte - muitas delas de origem e de atuação local com experiência na construção de infra-estruturas urbanas da cidade do Rio de Janeiro - que acabaram cedendo lugar às grandes, de influência nacional. A direção do Metrô-RJ praticou uma política de clara exclusão das empresas locais, uma vez que a partir de um determinado momento, elas não conseguiram contratos com a companhia. No entanto, muitas dessas empresas participaram efetivamente da obra como sub-contratadas das grandes empreiteiras; a mesma prática ocorreu com a construção da Ponte Rio-Niterói. A partir de 1974, existiria disponibilidade das construtoras instaladas no Rio de Janeiro - mão-de-obra e equipamentos - com o término da construção da Ponte RioNiterói, do Aeroporto do Galeão e do trecho urbano da Perimetral (obras na direção da Barra), dentre outras. Uma grande obra no Rio de Janeiro possibilitaria a continuação das atividades e segundo o raciocínio das próprias empresas, sempre interessa ao poder público impedir os problemas sociais que um grande número de desempregados com o término das 
grandes obras poderia trazer. As obras do Metrô, uma vez incentivadas, poderiam resolver os problemas acima durante o período da Fusão.

Não pôde ser observado, no entanto, movimentações explícitas pelas obras do Metrô-RJ, ficando a Mendes Júnior com a maior parte dos serviços. Ainda, lembrando Wilson Quintella, as grandes empresas da construção civil tinham uma proximidade com os dirigentes públicos, de forma a oferecer seus serviços garantindo a continuidade de seus negócios, que sobrepassavam a competência técnica e chegavam à construção de relações de confiança. De toda forma, as obras passaram sim das mãos de pequenos e médios empreiteiros para uma empresa da construção civil de grande porte, que pôde inclusive financiar as obras nos momentos mais críticos de descontinuidade no aporte de recursos.

Os grupos estrangeiros, produtores de materiais e equipamentos para o Metrô-RJ, sustentados pelos créditos vinculados ao fornecimento, estiveram presentes em praticamente todos os momentos de decisão significativos. No entanto, só penetraram nos setores onde a indústria nacional não estava suficientemente capacitada e nas áreas onde a tecnologia pudesse ser apreendida pelos grupos nacionais, revelando assim um domínio dos agentes públicos de decisão na estrita obediência a diretrizes maiores de política pública de sempre elevar os níveis de nacionalização da produção e dos serviços prestados. Não conseguiram entrar no setor da construção civil.

Os fornecedores estrangeiros de equipamentos constituíram-se efetivamente num setor de pressão nas decisões da Cia. do Metrô pelo tipo de equipamento a ser utilizado ao oferecer crédito e consultoria especializada no estabelecimento de especificações técnicas. No entanto, essa influência não parece ter sido real na decisão principal de se construir o Metrô. 
As tentativas estrangeiras de vender empreendimentos completos: estudos, projetos, obra, equipamentos e etc., não tiveram sucesso sobre os reais agentes da decisão.

Quanto à hipótese 3, não se pode dizer que a população da região metropolitana como um todo tenha reivindicado a construção do Metrô e nem que fosse ela o seu maior beneficiário. O sistema de transportes em questão não veio aliviar o eixo de deslocamentos mais carregado e mais carente e, com sua implantação, a administração pública não respondeu ao princípio do uso mais racional e universal do dinheiro público. A população de baixa renda, por exemplo, esperava melhorias no sistema férroviário na direção dos subúrbios e nas ligações feitas pela avenida Brasil, não compreendendo no que o Metrô Zona Norte - Zona Sul lhe pudesse ser útil. A população motorizada, de alta renda, se interessava pelas extensões viárias na direção da Zona Sul - Barra, e a população de classe média, possuidora ou aspirante do transporte individual, moradora da orla marítima e dos bairros mais tradicionais da Zona Norte, não demonstrou interesse pelo transporte de massa e não pressionou pelo Metrô em nenhum momento.

Observou-se uma indiferença geral quanto à solução a ser implantada e as poucas manifestações populares sobre o sistema metroviário foram, de início, de incredulidade quanto à sua realização, e durante a construção, elas foram efetivamente de repúdio em função dos problemas que a obra causava às atividades urbanas em geral. Vários bairros sofreram não só com as obras, mas especialmente com a paralisação das mesmas e com as dificuldades para sua retomada, muito tempo depois. A aceitação e a confiança no sistema é recente e é a classe média que mais utiliza o Metrô, ao substituir os lentos deslocamentos em superfície pelo sistema subterrâneo de grande confiabilidade relativa à segurança e ao tempo de deslocamento. 
E finalmente, quanto à hipótese 4, resta buscar na própria burocracia técnica dos planejadores do Metrô indícios de influência para a decisão. Embora muitos especialistas, integrantes ou não das inúmeras comissões técnicas que estudaram a viabilidade do empreendimento, tenham lutado pelo Metrô-RJ, através de posicionamentos públicos, conferências etc. não foram esses engenheiros que efetivamente participaram da decisão principal de se implantar o Metrô-RJ. Foi sim o seleto grupo de técnicos que inicialmente assessorava o Governo Federal na área de transportes inicialmente e posteriormente nos transportes urbanos que pode ter levado a União a se decidir pelo apoio explícito ao MetrôRJ. Esse grupo veio a constituir o Governo da Fusão e reforçar os quadros da Companhia do Metrô-RJ que passou a ter uma força expressiva na administração do estado, como empresa pública moderna gerida de forma racional, modelo para o estado. Com relações diretas com a Presidência da República, tanto o Governador Faria Lima quanto o Presidente do MetrôRJ, Noel de Almeida, tiveram acesso direto às decisões federais quanto a volume de recursos e cronograma de investimentos.

A Companhia do Metrô investiu sua equipe de planejamento de considerável poder de decisão quanto à implantação do sistema, tendo as atividades da mesma ultrapassado a área de intervenção da Companhia, elaborando estudos diretamente para a Secretaria Estadual dos Transportes. A decisão sobre a alteração de traçado e sobre a prioridade de implantação dos diversos trechos veio desse grupo da burocracia técnica. A alteração de prioridades na direção dos subúrbios, para a Pavuna, teve como razões principais, de uma parte, a intenção de dar um cunho social à obra - deselitizá-la dirigindo-a aos habitantes de menor poder aquisitivo. Por outro lado, utilizando-se o antigo trajeto da Ferrovia Rio d’Ouro passando por área de pouca densidade, pretendia-se criar um novo eixo de transportes que 
estruturasse o crescimento da cidade na direção Maria da Graça / Pavuna. Era previsto nessa linha, o uso de outra tecnologia para o sistema, optando-se por um veículo leve, de composição mais curta e de superfície, e que pudesse resultar num custo bastante inferior ao do metrô subterrâneo da linha 1. Os planejadores do Metrô-RJ justificavam assim a mudança de prioridades, acrescentando que o novo sistema poderia servir de modelo para a implantação de sistemas semelhantes em outras cidades brasileiras. O cunho social do empreendimento é discutível, dada a baixa densidade habitacional da área de abrangência, e a experiência com um sistema mais leve não se mostrou de grande relevância, uma vez que a diminuição de custos não aconteceu como prevista. Porém, claramente, a decisão não foi discutida num foro de abrangência mais ampla do que as reuniões técnicas. Pode-se concluir que da força adquirida pela equipe técnica dentro de uma companhia estatal poderosa, com apoio direto do Governo Federal, resultaram muitas decisões que não encontram eco no sistema de interesses da sociedade local.

Desta forma, pode-se concluir que nenhuma das hipóteses relativas às influências de grupos sociais ou econômicos específicos tenha sido determinante na decisão maior de se construir o Metrô-RJ, podendo ter havido algumas alianças no sentido de se alterar rumos nas atividades de construção civil, ou na opção por este ou aquele equipamento, pequenas alterações de traçado ou formas de se distribuir as frentes de obra. No entanto, a decisão maior para a implantação do empreendimento se deu num momento em que foram reunidas as condições políticas e institucionais propícias, independentemente das vontades locais. Embora houvessem estudos técnicos que embasaram a decisão maior pela implantação do Metrô-RJ, não foi a necessidade do sistema por parte da cidade e de seus habitantes, nem a racionalidade do mesmo e sua adequação técnica, que levou à decisão. Prevaleceram critérios alheios aos interesses dos atores locais, tendo sido sim, uma decisão diretamente ligada à esfera federal e cuja razão, podemos agora afirmar, esteve ligada muito mais ao 
planejamento mais geral do país, associado a uma ideologia centralizadora e autoritária de nacionalização e desenvolvimento.

Como vimos anteriormente, no capítulo inicial, a definição do tipo de desenvolvimento e as bases para sua realização em nosso país esteve fortemente alicerçada em planos elaborados na esfera federal - em grande parte implementados -, muito mais do que baseada nas condições de mercado interno e externo. Até meados dos anos 1970, o país não tinha uma política clara de transportes de passageiros urbanos, mas existia sim uma política de transporte de carga e de passageiros interurbana. Como vimos, a estratégia de desenvolvimento dos transportes no Brasil esteve baseada no auto-financiamento do setor através dos impostos sobre os combustíveis. Desta forma, ao se implementar a produção e consumo de automóveis, ônibus e caminhões, os impostos gerados especialmente através da gasolina - que era mais fortemente taxada do que o diesel - o país pode fazer face à construção de rodovias por onde esses veículos pudessem se deslocar por todo o país. Da justa medida da quantidade de recursos gerados através desse imposto direto que pudesse incentivar e não frear o consumo de veículos é que resultou o sucesso dessa política de incentivo ao transporte rodoviário e à produção de veículos. No entanto, a partir de meados de 1970, com as dificuldades que as cidades começaram a apresentar para a circulação de passageiros e mercadorias é que as atenções do Governo Federal se voltaram para os transportes intraurbanos - quando foram criadas as regiões metropolitanas, a CNDU, o Fundo de Desenvolvimento Urbano e posteriormente a EBTU - e parte dos impostos sobre combustíveis passou a ser utilizada nos transportes de massa, aí incluso o Metrô-RJ.

Assim, pode-se afirmar que a decisão do Governo Federal de liberar recursos para a construção do Metrô-RJ esteve integralmente inserida numa opção de política nacional, de 
grande abrangência, que pouco considerou os interesses e necessidades locais. No caso específico, esses recursos poderiam ter sido utilizados para as tão necessárias melhorias no sistema de trens de subúrbios, que apresentavam uma situação de degradação de grande intensidade, com um parque antigo e super-utilizado, mas o Governo Federal optou pelo Metrô-RJ como uma obra de grande visibilidade e que pudesse ser o elemento modernizador do setor ferroviário.

Embora de difícil comprovação e alicerçada em conceitos pré-estabelecidos de que a fusão dos dois estados não seria uma boa medida para a Guanabara, presente na reflexão de muitos pensadores até hoje, pode-se adiantar que o apoio federal ao Metrô-RJ foi uma compensação com relação à implantação, à revelia das forças locais, da reestruturação político-administrativa com a fusão dos dois estados - Guanabara e Rio de Janeiro, dotando o novo estado de uma grande obra urbana. Essa intervenção por parte do Governo Federal é tão determinante que, a partir do momento que este altera sua posição de forte apoio financeiro, em função das novas condições econômicas do país, a obra sofre paralisações, reforçando ainda mais a idéia de que as pressões locais não existiram ou foram muito pouco expressivas.

Cabe enfatizar que a longa trajetória de iniciativas para a decisão pela implantação do Metrô-RJ não se enquadra no modelo racional descrito no capítulo 1 e que, à época dessas ações, era o modelo explicativo idealizado para as decisões na esfera pública que ainda vigia. A decisão não foi o resultado de uma conceituação técnica adequada, acompanhada de métodos sofisticados de coleta e tratamento de informações e análises baseadas em passos racionais de encaminhamento, apresentando-se alternativas e decidindo-se pelo melhor projeto. 
Também não foi uma resposta ao modelo explicativo de que as decisões ocorrem de forma aleatória para resolver problemas locais imediatos, ou como resposta a interesses de grupos econômicos ou sociais mais influentes, baseado no consentimento mútuo dos inúmeros participantes do processo decisório, sem uma visão de conjunto, como defendido por vários autores americanos (ver Capítulo 1). Os autores franceses que prosseguiram nessa discussão sobre modelos de decisão (ver Capítulo 1) também afirmavam que a decisão racional não existe enquanto decisão única, e apontavam na direção da multiracionalidade dos atores limitada pelas organizações às quais esses atores pertencem. Estes também avançaram na análise das organizações, definindo os comportamentos mais ocorrentes dos agentes de decisão, o que não foi feito neste trabalho. Os autores de orientação marxista foram mais além nessa discussão apresentando uma correspondência entre os atores e as classes sociais que os mesmos representam. Porém, são as análises e conclusões do trabalho elaborado por Cintra e Gama de Andrade para o estudo das práticas de planejamento e das decisões no Estado de Minas Gerais que chegaram a resultados mais próximos aos obtidos neste trabalho de investigação. Esses autores afirmam que as tentativas de planejamento abrangente naquele caso pareceram a princípio inadequadas e frustrantes, mas que na implementação de projetos pontuais - como se não existisse planejamento algum - os resultados foram decisões acertadas que, na prática, obedeceram uma agenda de prioridades que funcionou como guia para essas decisões de caráter pontual. No caso do Metrô-RJ, a decisão pela implantação do sistema não esteve articulada a nenhum estudo - um Plano de Transportes Urbanos, por exemplo - que propusesse as melhores ações para se resolver o sistema de transportes urbanos do Rio de Janeiro. Ela respondeu a um esforço de planejamento mais geral, no nível federal, que teve como objetivo, a partir de meados dos anos 1970, dotar as maiores cidades brasileiras de sistemas de transportes de massa, sem 
muita clareza, no entanto, de qual sistema seria o mais adequado para cada caso. Assim, uma ação de caráter incremental foi efetivamente orientada por uma decisão de política pública mais ampla, de caráter nacional.

Pode-se afirmar que numa visão mais geral do país, o Metrô-RJ se insere nas decisões assim como vários projetos pontuais que estiveram amparados por uma visão de conjunto, a visão desenvolvimentista da oferta de infra-estrutura e da implantação industrial que embasou o planejamento do desenvolvimento brasileiro no período em questão, numa prática autoritária que não foi discutida pela sociedade brasileira. O processo decisório da implantação do Metrô-RJ encaixa-se no contexto político administrativo descrito no capítulo 1, no qual as decisões foram tomadas a partir de uma política pública relativa, inicialmente aos transportes em geral e posteriormente aos transportes urbanos, iniciada nos anos 1950 e perseverada nos anos da ditadura militar e que representaram os esforços de se imprimir uma maior racionalidade e planejamento nas ações públicas.

Como era de se esperar, o processo de decisão não chegou a incluir, em nenhum momento, qualquer visão que futuros usuários do sistema ou que qualquer outro segmento social presente no Rio de Janeiro pudesse ter sobre a solução que foi definida, ou seja, as decisões não incluíram em nenhum momento a visão da demanda. Como pudemos observar nas discussões apresentadas no capítulo 7, a população não foi convidada ou incentivada a se manifestar e quando o fez, atuou reativamente em função dos inconvenientes que a implantação das obras estava causando ${ }^{2}$.

\footnotetext{
${ }^{2}$ A equipe da Secretaria de Transportes do Rio de Janeiro, à época, afirmou em entrevista que o governo da Fusão e os sucessores imediatos não compreenderam que a implantação do Metrô-RJ enquanto uma obra isolada dos demais sistemas de deslocamentos urbanos não teria a função estruturadora de longo prazo do conjunto dos modos que se esperava. Eram necessárias muitas ações complementares de implantação concomitante, segundo entrevistas com Josef Barat, anteriormente citadas.
} 
Assim, este trabalho, ao identificar os principais condicionantes para as decisões quanto à produção de uma intervenção específica na cidade do Rio de Janeiro - a construção de um sistema de transporte metroviário -, a partir do comportamento dos atores, teve como principal objetivo contribuir para que decisões de mesma natureza possam trilhar um caminho de maior transparência. Outras intervenções poderão ser analisadas de forma semelhante, viabilizando o estabelecimento de futuras ações normativas no sistema de decisões, tornando-o mais conhecido de uma parcela maior da população e conseqüentemente mais democrático. 


\section{REFERÊNCIAS BIBLIOGRÁFICAS}

ABRAMO, P. Mercado e Ordem Urbana: do Caos à Teoria da Localização Residencial. Bertrand Brasil, 2007. 224 p.

ALLISON, G. Essence of Decision: Explaining the Cuban Missile Crisis. Boston, [s.n.], 1971. 329 p.

ANDERSEN, J. E. Public Policy-Making. New York: Holt, Reinhart and Winston, 1977. 178 p.

ANTÃO da SILVA, P.; BANA e COSTA, C.; NUNES CORREIA, F. Avaliação

Multicritério das Incidências Ambientais de Medidas de Controlo de Cheias: o Caso da Ribeira do Livramento. [17 p.] Disponível em:

<http://www.aprh.pt/cpngressoagua98/files/com/106.pdf> Acesso em: 26 jan. 2008.

ANTP - Associação Nacional de Transportes Públicos. Anuário ANTP dos Transportes Públicos. São Paulo, 1996. 250 p.

Anuário ANTP dos Transportes Públicos. São Paulo, 1998. 300 p.

BANA e COSTA, C. A.; DE CORTE, J.; VANSNICK, J. Macbeth. London School of Economics Working Paper 03.56, sem paginação, sem data. Disponível em:

<http://wwwlse.ac.uk/collections/operational/research/pdf> Acesso em 01 ago. 2008.

BARAT, J. Estrutura Metropolitana e Sistema de Transportes: Estudo de Caso do Rio de Janeiro. IPEA - Série Monográfica, no. 20. Rio de Janeiro, 1975. 292 p.

BLEITRACH, D. Région Métropolitaine et Appareils Hégémoniques Locaux. Espaces et Societés, mars/juin, 1977.

BOBBIO, N.; MATTEUCCI, N.; PASQUINO, G. (Orgs.) Dicionário de Política. Brasília: $\mathrm{UnB}, 13^{\mathrm{a}}$ ed. 2007. $1.332 \mathrm{p}$.

BRANCH, M. C. Comprehensive City Planning - General Theory and Practice. Los Angeles: Palisades Publishers, 1983. 203 p.

. Continuous City Planning - Integrating Municipal Management and City Planning. New York: John Wiley and Sons, 1981. 181 p.

BRASIL. Exposição de Motivos no 106, maio 1970.

Decreto-Lei 200, de 25 de fevereiro de 1967.

Resolução CONAMA no. 1, de 23 de janeiro de 1986.

Lei Federal no. 1.257: Estatuto da Cidade, de 10 de Julho de 2001.

BRASILEIRO, A. M. A Fusão: Análise de uma Política Pública, IPEA. Série Estudos para o Planejamento, no. 21. Brasília, 1979. 364 p. 
BRESSER-PEREIRA, L. C. A Reforma Gerencial do Estado de 1995. Revista de Administração Pública no. 3, 34 (4), p. 55-72, jul. 2000.

. Do Estado Patrimonial ao Gerencial. In: PINHEIRO; WILHEIM; SACHS (Orgs.). Brasil: Um Século de Transformações. São Paulo: Cia. das Letras, 2001. p. 222-259.

Sociedade Civil: sua democratização para a reforma do Estado. In: BRESSERPEREIRA, L. C.; WILHEIM J.; SOLA, L. (Orgs.) Sociedade e Estado em Transformação. UNESP/ENAP, 1999. p. 67-116.

.Da Política de Elites à Democracia de Sociedade Civil. In:VELLOSO, J. P. dos R. (Org.) Brasil 500 Anos Futuro, Presente, Passado. Rio de Janeiro: José Olympio Editora, 2000. p. 517-538.

CAIDEN, N.; WILDAVSKY, A. Planning and Budgeting in Poor Countries. New York: John Wiley, 1974.

CÂMARA DOS DEPUTADOS (Comissão de Desenvolvimento Urbano e Interior); SECRETARIA ESPECIAL DE DESENVOLVIMENTO URBANO DA PRESIDÊNCIA DA REPÚBLICA; CAIXA ECONÔMICA FEDERAL; INSTITUTO POLIS. Estatuto da Cidade - Guia para implementação pelos municípios e cidadãos. Brasília: Câmara dos Deputados - Coordenação de Publicações, 2a . ed., 2002. 273 p.

CAMPANAC, E.; COING, H. Marché du Travail et Urbanisation: Le Rôle du Ramassage dans les Politiques d'Entreprises. La Vie Urbaine. Paris, 2/3/4, 1976.

CARVALHO, G. S.; MINGOTI, S. A Manual do Usuário: Programas para realização da Análise Hierárquica. UFMG, Instituto de Ciências Exatas, Departamento de Estatística, sem data. [15 f.] Disponível em <http://www.est.ufmg.br/estatistica_industrial/manual $>$. Acesso em 26 maio 2008.

CASTELLS, M. Vers une théorie sociologique de la planification urbaine. Paris: Maspero, 1972. Inicialmente publicado em 1969.

La Cuestion Urbana. Madrid: Siglo XXI de Espagna Editores S.A., 1979. 518 p.

. A Sociedade em Rede - A Era da Informação, Sociedade e Cultura. São Paulo:

Editora Paz e Terra, 1999, v 1.

CASTELLS, M.; GODARD, F. Monopolville: l'entreprise, l'état, l'urbain. Paris-La Haye: Mouton, 1974.

CARDOSO, F. H. Conferência proferida no College de France. Paris, 18 maio 1981.

CCN - HOCHTIEF - DECONSULT. Study of Technical and Economic Feasibility of the Metrô of Rio de Janeiro. Rio de Janeiro, dez. 1968. 581 p.

CENTER FOR URBAN TRANSPORTATION RESEARCH. TDM in Europe - a Synthesis of Research Findings: Annotated Bibliography of TDM in Europe. Disponível em $<$ http://www3.cutr.usf $>$ Acesso em: 22 set. 2009. 
CHAPOUTOT, J; GAGNEUR, J. Mobilisation de la Force de Travail et Gestion des Transports Urbains. La Vie Urbaine. Paris, 2/3/4, 1976.

CINTRA, A. O.; GAMA DE ANDRADE, L. A. Reflexões sobre uma Experiência Estatal. In: CINTRA, A. O.; HADDAD, P. R. (Orgs.). Dilemas do Planejamento Urbano e Regional no Brasil. Rio de Janeiro: Zahar Editores, 1978.

COING, H. Car de Ramassage et Marché d'Emploi: le textile de Roubaix - Tourcoing. DGRST / BETURE, Paris, 8/75.

COMPANHIA DO METROPOLITANO DO RIO DE JANEIRO. O Metrô do Rio de Janeiro e o futuro Sistema Integrado de Transporte de Massa. Rio de Janeiro: Diretoria de Planejamento, out. 1976, 225 p.

Contribution de la Compagnie do Metro de Rio de Janeiro a la XXXVIII Session de I'Union Internationale des Transports Publics”. Rio de Janeiro, oct. 1977, sem paginação.

Livro Histórico do Metrô. Rio de Janeiro [s.n.], 1977.

Linhas e Estações da Rede Básica. Rio de Janeiro [s.n.], 1978, 35 p.

(DP/DEPLAN/DIEST). Estudo Comparativo entre as Alternativas de Expansão

da Rede Prioritária Básica. [1979]. 46 p.

. Relatórios de Diretoria. 1978-1981.

Relação de Operações de Crédito Externo. 1981. 6 f.

Relação de Operações de Crédito Interno. 1981. 20 f.

CONSÓRCIO LOGIT - OFICINA - JGP. Plano Diretor de Transporte Urbano da Região Metropolitana do Rio de Janeiro - PDTU. Capítulo 2 - Estrutura do Serviço Atual de Transportes. [S.l.: s.n.], 2004, 51 p. e Capítulo 3 - Prognóstico. [S.l.: s.n.], 2005, 33 p.

CORREIA, F. G. Breve Histórico da Questão Habitacional no Rio de Janeiro. 44 p.

Disponível em <http://www.achegas.net/numero/31/fernanda_correa_31.pdf > Acesso em 30 set. 2008.

COSTA, J. G. Planejamento Governamental - a experiência brasileira. Fundação Getúlio Vargas, 1971. 569 p.

COSTA, N. da; ABE, J. M., SILVA FILHO; J. I.; MUROLO, A. C.; LEITE, C. F. S. Lógica Paraconsistente Aplicada. São Paulo: Editora Atlas, 1999. 214 p.

COX, E. Fuzzy Fundamentals. EUA: IEEE Spectrum, 1992.

CROZIER, M. Le Phénomène Bureaucratique. Paris: Éditions du Seuil 1963. 382 p. 
CROZIER, M.; FRIEDBERG, E. L’Acteur et le Système. Paris: Éditions du Seuil, 1977. 437 p.

DA MATTA, R. Considerações Sócio-Antropológicas sobre a Ética na Sociedade Brasileira. informe apresentado ao Banco Interamericano de Desenvolvimento, nov. 2001, [16 p.] Disponível em: <http://www.codigodeetica.es.gov.br/artigos > . Acesso em 25 ago. 2008.

DARBÈRA, R. Methodologial and Institutional Issues in Urban Transportation Planning for Less Developed Countries. In: PTRC - Planning and Transport, Research and Computation Annual Summer Meeting. Warwick, Grã-Bretanha, jul. 1979. 12 f.

DARBÈRA, R.; MARCHAND, B. Les Determinants de la Politique Locale des Transports Urbains - Trois Etudes de Cas au Brésil. Créteil, França [s.n.], 1983. Documento de Trabalho. 80 p.

DARBÈRA, R.; PRUD’HOMME, R. Transports Urbains et Développement Économique Du Brésil. Paris: Econômica, 1983. 166 p.

DAVIDOFF, P. Advocacy and Pluralism in Planning. In FALUDI, A. (Org.) A Reader in Planning Theory. New York: Pergamon, 1973. Primeiramente in: Journal of the American Institute of Planners, no. 31, nov. 1965.

DHAL, R. A. Who Governs? Democracy and Power in an American City. Yale University Press, 1961.

DUARTE, R. G. Centralidade, acessibilidade e o processo de reconfiguração do sistema de transporte na metrópole carioca dos anos de 1960. In: Revista Território. Rio de Janeiro, ano VII, no. 11, 12 e 13 - set./out. 2003. p. 91-106.

ETZIONI, A. Mixed-scanning: a Third Approach to Decision Making. In: FALUDI, A. A Reader in Planning Theory”. New York: Pergamon Press, 1973. Primeiramente in: Public Administration Review, dez. 1967.

FALUDI, A. (Org.) Planning Theory. New York: Pergamon Press, 1973. 399 p.

FETRANSPOR - Federação das Empresas de Transportes Rodoviários do Leste-Meridional do Brasil. Carta do Rio de Janeiro - Conclusões do $2^{\circ}$. Encontro dos Transportadores de Passageiros do Rio de Janeiro. In: Revista dos Transportes Públicos - ANTP, 1990, V 50. p. 79-83. Publicada originalmente em todos os jornais de grande circulação do Estado do Rio de Janeiro em 20 out. 1990.

FUNDAÇÃO IBGE. Sinopse Preliminar do Censo Demográfico: IX Recenseamento Geral do Brasil - 1980. Secretaria de Planejamento da Presidência da República. v 1, tomo 1, no. 1.

FURTADO, C. O Brasil Pós-Milagre. Rio de Janeiro: Ed. Paz e Terra, 1981.

GAKENHEIMER, R.; EL-HAWARY; M. E MICHAEL, M. Toward Rationalizing the Transport Project Planning Process in Cairo, Egypt. out. 1978, mimeo. $41 \mathrm{f}$.

GAZETA MERCANTIL. Balanço Anual. 1979 e 1981. 
GEIGER, P. P. Evolução da Rede Urbana Brasileira. Rio de Janeiro: CBPE - Centro Brasileiro de Pesquisas Educacionais, 1963. 462 p.

GHERTMAN, M. La Prise de Décision. Paris: Presses Universitaires de France e IRM Institut de Recherche et d’Information sur les Multinationales, 1982, 397 p.

GONÇALVES, Â. F. M.; PORTO JÚNIOR, W. Avaliação de alternativas físicas e operacionais para o projeto do sistema VLT-Rio com o emprego do simulador SIMVLT. In: Revista dos Transportes Públicos - ANTP, v 70, p. 73-85, 1996.

Grilagem Oficial. Revista Veja, 14 maio 1980. p. 56.

INTERNATIONAL BANK FOR RECONSTRUCTION AND DEVELOPMENT. $\boldsymbol{A}$ Framework for Urban Development Studies. Economics Working Paper no. 73, Mars 1970. $40 \mathrm{p}$.

IPEA/IPLAN. Região Metropolitana do Grande Rio: Serviços de Interesse Comum. Brasília: IPEA, 1976, 247 p.

ISMAEL, R. Do Estado Patrimonial ao Estado Pós-Burocrático: considerações sobre a defesa do Interesse Público. Departamento de Sociologia e Política, PUC-Rio de Janeiro, [9 p.], Disponível em <http://aol.universiabrasil.net/material/img/ilustr/2005/jun/anpuh.doc> Acesso em: 11 jun. 2008.

J. F. G. O Longo Caminho Subterrâneo. Jornal do Brasil, de 17 jun. 1970.

JAIME LERNER PLANEJAMENTO URBANO Sistema Integrado de Transportes Versão Preliminar - Estado do Rio de Janeiro. Projeto Rio Ano 2000, Governo Leonel Brizola. Rio de Janeiro: [s.n.], jan. 1984.

JORNAL DO BRASIL. 1978-1980.

LAGO, L. C. Estruturação socioespacial na metrópole do Rio de Janeiro: reprodução ou alteração nas condições de (não) acesso ao urbano? [2002]16 f. Disponível em $<$ http://www.observatoriodasmetropoles.ufrj.br/download/lago_estruturacao.pdf $>$ Acesso em 15 mar. 2008.

LEEDS, A.; LEEDS, E. A Sociologia do Brasil Urbano. Rio de Janeiro: Zahar, 1978, 327 p.

LEME, M. C. (Org.) Urbanismo no Brasil - 1895-1965. São Paulo: FUPAM, Studio Nobel, 1999. 599 p.

A Formação do Pensamento Urbanístico no Brasil, 1895-1965. In LEME, M. C.

(Org.). Urbanismo no Brasil - 1895-1965. São Paulo: FUPAM, Studio Nobel, 1999. p. 2038.

LINDBLOM, C. E. The Science of Muddling Through. In FALUDI, A. (Org.) A Reader in Planning Theory. New York: Pergamon Press. Primeiramente publicado na Public Administration Review, Spring 1959. 
LISBOA, M. V.; WAISMAN, J. Análise Multicritério Aplicada ao Estudo de Alternativas de Traçado de Rodovias: uma abordagem sócio-ambiental. Boletim Técnico FATEC-SP BT/22. São Paulo, jul. 2007. p. 28-33.

LISBOA, M. V. Aplicação do Método de Análise Hierárquica - MAH para o Auxílio à Tomada de Decisão em Estudos de Alternativas de Traçado de Rodovias. Disponível em $<$ http://www.guiadelogistica.com.br> Acesso em 15 jun. 2005.

LODDER, C. A. Distribuição de Renda nas Áreas Metropolitanas. IPEA, Coleção Relatórios de Pesquisa no. 31. Rio de Janeiro, IPEA, 1976. 103 p.

LOJKINE, J. Contribution a une Theorie Marxiste de l'Urbanization Capitaliste. Cahiers Internationals de Sociologie, L II, 1972.

LOJKINE, J. Le Marxisme, I'État et la Question Urbaine. Paris: PUF, 1977. 362 p. Contribution a une Theorie Marxiste de l'Urbanization Capitaliste. Cahiers Internationals de Sociologie, L II, 1972.

LOPES, G. P.; CAVALLIERI, F. Favelas Cariocas: Comparação das Áreas Ocupadas 1999/2004. Prefeitura da Cidade do Rio de Janeiro, Instituto Municipal de Urbanismo Pereira Passos - IPP, Diretoria de Informações Geográficas - DIG. Rio de Janeiro, 2006. 50p.

LOW-BEER, J. O Estado e as Políticas públicas - Uma revisão histórica da atuação estatal no Brasil (1950 a 1997). Trabalho Programado 1, FAUUSP, mimeo, abr. 2000, 34 f.

. Os Serviços Públicos Urbanos e a Regulação: novo enfoque em Políticas Públicas. Revista Pós, no. 12, p. 34-49, dez. 2002.

O Novo Paradigma das Políticas Públicas Urbanas: A regulação dos Serviços Públicos - Limites e Alcances. 2000. 108 f. Tese de Doutorado apresentada à Faculdade de Arquitetura e Urbanismo da Universidade de São Paulo, FAUUSP, mimeo, 2000.

MACDOWELL, F. Planejamento Integrado de Transportes - PIT: O Planejamento dos Grandes Projetos Públicos. IESA Internacional de Engenharia. Rio de Janeiro: [s.n.], 1981. $123 \mathrm{p}$.

Análise e Proposição para a Ocupação do Solo do Rio: uma visão sistêmica. Rio de Janeiro: FIRJAN, ACIRJ, SINDUSCON, ADEMI, AMPEC, 1991. 30 p.

MARCH, J. G. (org.) Handbook of Organizations. Chicago, Rand McNally, 1965.

MARCH, J.; SIMON, H. A. Organizations. New York: Wiley, 1958.

MAY, N. e RIBEIL, G. Les Processus Revendicatifs em Matière de Transports Urbains. La Vie Urbaine. Paris, 1976, no. 2/3/4.

MCGRANAHAN, G. Demand-Side Water Strategies and the Urban Poor. IIED

International Institute for Environment and Development, PIE Series no. 4. Stevenage, U. K.: [s.n.], 2002, 67 p. 
Metrô amplia rede a partir de 1981 até cobrir 93 km. Jornal do Brasil, 12 jun. 1978.

Metrô começará obra para ligar Leblon à Tijuca em 1983. Jornal do Brasil, 14 abr. 1981.

Metrô poderá passar por Copacabana cortando morros. Jornal do Brasil, 24 nov. 1978.

MEYERSON, M. Building the Middle-Range Bridge for Comprehensive Planning. In: FALUDI. A. (Org.) A Reader in Planning Theory. New York: Pergamon Press, 1973.

MINISTÉRIO DA CIDADE, Secretaria Nacional de Transporte e da Mobilidade Urbana.

PLAN MOB - Construindo a Cidade Sustentável. Caderno 1 - Caderno de Referência para Elaboração de Plano de Mobilidade Urbana, 2007. 180 p.

MISSE. D. G. Agências Reguladoras - Muito mais do que Modismo. Prisma Jurídico, v.5. São Paulo, p. 277-290, 2006.

MOTTA, N. Fusão, confusão, separação. Folha de São Paulo, 18 mar. 2005.

MOURTHÉ, A. Metrô do Rio: análise crítica da concessão. Revista dos Transportes Públicos - ANTP. São Paulo, v 83. p. 57-64, 1999.

MYERS D. e KITSUSE, A. Constructing the Future in Planning: a Survey of Theories and Tools. Journal of Planning Education and Research. v. 29, p. 221-231, Summer 2000.

MUNICIPAL RESEARCH AND SERVICES CENTER OF WASHINGTON. Washington State's Commute Trip Reduction Program. Disponível em <http://www.mrs.org/subjects/transpo/TDM.aspx > . Acesso em 20 set. 2008.

NICOLAS, J. e BERNARD, JC. Crise des Transports et Enjeaux Sociaux em Région Parisienne. Espaces et Sociétés. Paris, no. 13/14, p. 93-110, 1977.

O GLOBO. 1978-1980.

OLIVEIRA, A. M. S. L.; VILHENA, L. M.; SILVA, M. L. A.; TIBÚRCIO, S. M. N. O. Contribuição do Estudo sobre o Valor das Terras no Município do Rio de Janeiro. Revista Municipal de Engenharia. Rio de Janeiro: Prefeitura da Cidade do Rio de Janeiro, v XXXIX, p. 72-85, out./dez. 1983.

OROFINO, F. V.G. Aplicação de um Sistema de Suporte Multicritério - SAATY for WINDOWS - na Gestão dos Resíduos Sólidos de Serviços de Saúde: caso do Hospital Celso Ramos. Capítulo 4 - O Processo Decisório, dissertação para obtenção do título de Mestre em Engenharia, UFSC - Universidade Federal de Santa Catarina, Florianópolis 1996, sem paginação. Disponível em:

<http://www.eps.ufsc.br/disserta97/falvia/index.htlm>. Acesso em: 26 maio 2008.

OSÓRIO, M. A Fusão: equívocos e memória. Disponível em: < http://www.coreconrj.org.br/artigos_det.asp?Id_artigos=6>. Acesso em: 05 ago. 2005. 
PALHARES, G. L.; MARTINS, J.A. Avaliação de Alternativas de Transporte do Corredor Rio de Janeiro - Niterói - São Gonçalo - Itaboraí: o Método da Análise Hierárquica Multicriterial. In: Anais do XIV Congresso da Associação Nacional de Pesquisa e Ensino em Transportes, 2000, Gramado, RS. Panorama Nacional da Pesquisa em Transportes 2000. Rio de Janeiro: ANPET, 2000. p. 411-422.

PAULA, D. A. Ferrovias x Rodovias: Agentes e Agências na Construção de Projetos Nacionais de Transportes (1920-1954). Universidade Federal de Uberlândia. [11 p.]

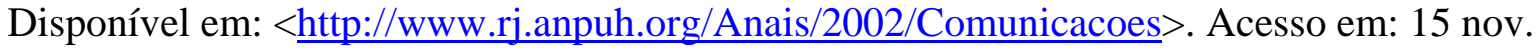
2008.

PINHEIRO, T. De Chagas Freitas a Anthony Garotinho (ou) Do clientelismo ao assistencialismo. Portal Imprensa. Disponível em: <http://portalimprensa.uol.com.br/portal/foca_online/2004/12/09/imprensa2691.shtml $>$. Acesso em: 29 out. 2008.

POULANTZAS, N. Les Classes Sociales das le Capitalisme Aujourd'hui. Paris: Seuil, 1974. 347 p.

PREFEITURA DA CIDADE DO RIO DE JANEIRO, Secretaria Municipal de Planejamento e Coordenação Geral. PUB Rio - Plano Urbanístico Básico da Cidade do Rio de Janeiro. Rio de Janeiro, jun. 1977. 280 p.

QUINTELLA, W. Memórias do Brasil Grande: a história das maiores obras do país e dos homens que a fizeram. São Paulo: Editora Saraiva, 2008. 426 p.

RABINOVITZ, F. Politics, Personality and Planning. In: FALUDI, A. (Org.) A Reader in Planning Theory. New York: Pergamon Press, 1973. Primeiramente publicado na Public Administration Review, mar. 1967.

REIS, J. de O. O Rio de Janeiro e seus Prefeitos: Evolução Urbanística da Cidade. Prefeitura da Cidade do Rio de Janeiro, Rio de Janeiro, 1977. 167 p.

RENCONTRE DE RECHERCHE EXPLORATOIRE SUR LES TRANSPORTS URBAINS DANS LES PAYS EM DÉVELOPPEMENT. Paris, mars1981, mimeo.

- ALLOUCH, J. F. Le Système de Transport Collectif a Quito: Elements de Diagnostic.

- ARIAS, C. H. Transportation Planning - The Case of Quito - Ecuador.

- BAOUENDI, A. La Marche a Pieds dans le District de Tunis.

- BEAUVIR, C. Mobilité et Transports Urbains a Quito.

- BUDIN, K. Quelques Elements de Reflexion sur la Méthodologie des Études de Transports Urbains et Suburbains das les Pays en Voie de Développement.

- DE BUEN, O. Urban Transportation in Mexico: System Perspective and Research.

- DE LA BARRA, T. Urban Land Use and Transportation Research Requirements.

- DUNIN, L. F. La Croissance des Villes et les Transports.

- EL-HAWARY, M. e HUZAYYIN, A. S. Transportation and Other Impacts of Changing Shop Opening Hours in Greater Cairo, a General Overview.

- FIGUEIROA, O. - Transports et Développement Urbain dans le Cas de Quito.

- VARGAS, V. I. Le Transport de Personnes dans L’Aglomeration de Mexico. 
RENCONTRE DE RECHERCHE DE L'IRT - INSTITUT DE RECHERCHE DES

TRANSPORTS. Paris: sept. 1983, mimeo.

- GODARD, X. Les Différentes Forms de Transport Collectif a Brazzaville.

- MARCHAND, F. Diversité Institutionelle des Transports Urbains - Étatisation ou Coordination? Les Cas de Guadalajara, México.

- $\quad$ NICOT, B. H. La Place des Transports Informels das les Villes Indiennes.

REVISTA DOS TRANSPORTES PÚBLICOS - ANTP. 1978-2006, 90 volumes.

REVISTA DO METRÔ. Edição Comemorativa da Inauguração do Metrô do Rio de Janeiro, v 1, no. 1. Rio de Janeiro, mar. 1979. 72 p.

REVISTA VEJA, 14 maio 1980.

REVISTA VISÃO. Balanço Anual, Quem é Quem. 1970, 1972, 1976.

REZENDE, V. F. Evolução da Produção Urbanística na Cidade do Rio de Janeiro. In: LEME, M. C. (Org.) Urbanismo no Brasil: 1895-1965. São Paulo: FUPAM, Studio Nobel, 1999. p. 39-70.

RIBEIRO, L. C. de Q. Da Propriedade Fundiária ao Capital Incorporador: as formas de produção da moradia na cidade do Rio de Janeiro. 1991, 326 f. Tese de Doutoramento apresentada à Faculdade de Arquitetura e Urbanismo, Universidade de São Paulo, 1991.

RIBEIRO, L. C. de Q.; LAGO, L. C. A Oposição Favela-Bairro no Espaço Social do Rio de Janeiro. Fundação SEADE, 2007. [16 p.] Disponível em:

$<$ http://www.observatoriodasmetropoles.ufrj.br/download/observatorio_educacao $>$ Acesso em: 15 mar. 2008.

ROBINSON, I. Beyond the Middle-range Planning Bridge. In: FALUDI, A. (Org.) A Reader in Planning Theory. New York: Pergamon Press, 1973.

SANTOS, A. M. S. P. Economia, Espaço e Sociedade no Rio de Janeiro. Rio de Janeiro: FGV Editora, 2003. 226 p.

SAPSA, Governo do Estado do Rio de Janeiro, FUNDREN. Plano Diretor de Transportes da Região Metropolitana do Rio de Janeiro - Diagnóstico. Documento de Trabalho, [1980].

SCHIMDT, A. M. A. Processo de Apoio à Tomada de Decisão: abordagens AHP e MacBeth. 1995. Dissertação apresentada para obtenção do título de Mestre em Engenharia, Universidade Federal de Santa Catarina, Florianópolis. Disponível em:

<http://www.eps.ufsc.br/disserta/angela/indice/index.htlm>. Acesso em 08 ago. 2008.

SCHNOOR, J. A Harmonia do Desenvolvimento Urbano em Função da Rede de Transporte Coletivo de Massa. Rio de Janeiro: BNH, 1975. 127 p.

SCHOPPA, R. F. Transporte Urbano na Região Metropolitana do Rio de Janeiro: caos ou integração. Revista dos Transportes Públicos - ANTP. São Paulo, v 61, p. 59-78, 1993. 
Secretário de Planejamento acha que metrô deve começar com ligação Centro-subúrbio. Jornal do Brasil, 06 jul. 1978.

SECTRAN - SECRETARIA DE ESTADO DE TRANSPORTES, Governo do Estado do Rio de Janeiro. Evolução dos Transportes de Passageiros no Rio de Janeiro. Disponível em: <http://www.sectran.rj.gov.br>. Acesso em 25 jan. 2007.

Evolução dos Transportes de Passageiros no Rio de Janeiro. Disponível em: $<$ http://www.sectran.rj.gov.br>. Acesso em 25-01-2007.

SILVA, M. L. P. Os Transportes Coletivos na Cidade do Rio de Janeiro: Tensões e Conflitos. Prefeitura da Cidade do Rio de Janeiro, Secretaria Municipal de Cultura, Turismo e Esportes, coleção Biblioteca Carioca, v 20, 1992. 177 p.

SILVA, R. T. The Connectivity of the Infrastructure Networks and the Urban Space of São Paulo in the 90s. Mimeo. $21 \mathrm{f}$.

SILVA FILHO, J. I.; ABE, J. M. Introdução à Lógica Paraconsistente Anotada com Ilustrações. Santos: Editora Emmy, 2000. 166 p.

SISSON, R. Os três Centros do Rio. Revista Municipal de Engenharia, Prefeitura da Cidade do Rio de Janeiro, v XXXIX, p. 55-71, out./dez. 1983.

SFEZ, L. Critique de la Decisión. Paris: Presses de la Fondation Nationale des Sciences Politiques, 1981. $392 \mathrm{p}$.

Décision et Pouvoir dans la Société Française. Colóquio dirigido por Lucien Sfez. Paris: Union Générale Éditions, 1979. 433 p.

TATIBANA, C. Y.; KAETSU D. Y. Homepage de Redes Neurais.Disponível em <http://www.din.uem.br/ia/neurais $>$. Acesso em: 03 jul. 2005.

Técnico sugere metrô pela encosta. Jornal do Brasil, 12 jun. 1977.

THONSON, J. M. Modern Transportation Economics. USA: Penguin, 1974.

Um investimento de Cr\$ 15.225.000.000,00. Construção Pesada, ano 09, n. 97, p. 30-31, fev. 1979.

VASCONCELLOS S. C. e BALASSIANO R. An integration proposal to the transport system of the city of Rio de Janeiro. [2003] 7 p. Disponível em:

$<$ http://www.codatu.org/english/publication/proceeding/conference/coadatu11/Papers/balassia no.pdf>. Acesso em: 22 fev. 2007.

VICTORIA TRANSPORT POLICY INSTITUTE. TDM Encyclopedia. Disponível em: $<$ http://www.vtpi.org/tdm/tdm12.htm>. Acesso em: 22 jul 2008.

VILAS BOAS, C. de L. Análise da Aplicação de Métodos Multicritérios de Apoio à Decisão (MMAD) na Gestão de Recursos Hídricos. Disponível em:

<http://www.cprm.gov.br/rehi/simposio/go> . Acesso em: 26 maio 2008. 
VILLAÇA, F. Espaço Intra-Urbano no Brasil. São Paulo: FAPESP, 2001. 373 p.

2005.. Sem os Erros do Presente. Tendências/Debates, A3, Folha de São Paulo, 20 maio

WAKELEY, P. Notes on the History of the Development Planning Unit. Londres: DPU, 2005. 24 p.

WEISS, Z. City Design Centers - Mechanism for Citizen Participation in the Planning Process. ASPO Planning, 1971. p. 132-151.

\section{Páginas Internet visitadas em diversos anos e confirmadas em 2008:}

<http://www.almacarioca.com.br/monroe.htm>, página official da ONG Alma Carioca.

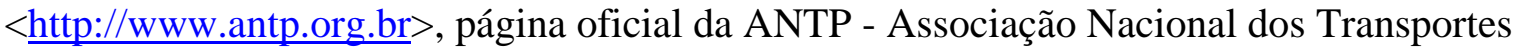
Públicos.

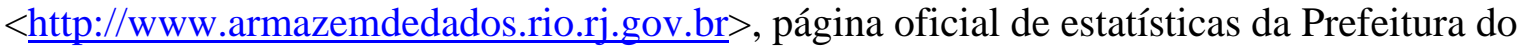
Município do Rio de Janeiro.

< http://www.barcas-sa.com.br> $>$, página oficial da Barcas SA Transportes Marítimos.

$<$ http://www.central.rj.gov.br $>$, página oficial da CENTRAL - Companhia Estadual de Engenharia de Transportes e Logística.

< http://www.codatu.org>, página oficial da CODATU - Coopération pour le Développement des Transports Urbains et Périurbains.

<http://www3.cutr.usf.edu/tdm>, página oficial do Center for Urban Transportation Research.

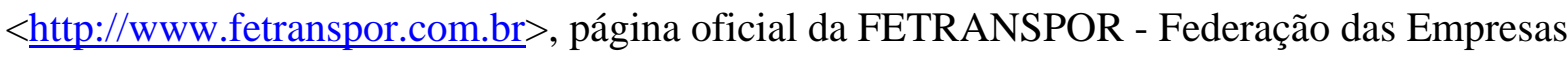
de Transportes de Passageiros do Estado do Rio de Janeiro.

<http://www.geipot.gov.br> $>$, página oficial da Empresa Brasileira de Planejamento de Transportes, em liquidação, mas que ainda apresenta dados gerais sobre o tema.

<http://www.ibam.org.br> $>$, página oficial do IBAM - Instituto Brasileiro de Administração Municipal.

< http://www.metrorio.com.br> , página oficial do METRÔ- RIO, Metrô do Rio de Janeiro.

<http://www.riotrilhos.rj.gov.br>, página oficial da RIO TRILHOS - Companhia de Transportes Sobre Trilhos do Estado do Rio de Janeiro, sucessora da Cia do Metropolitano do Rio de Janeiro.

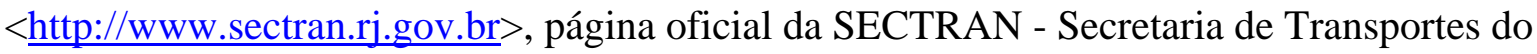
Estado do Rio de Janeiro. 


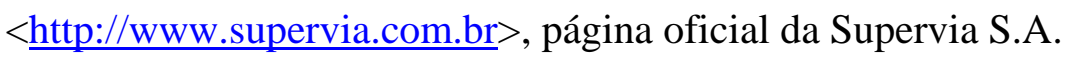

< http://www.wikipedia.org>, página de pesquisa.

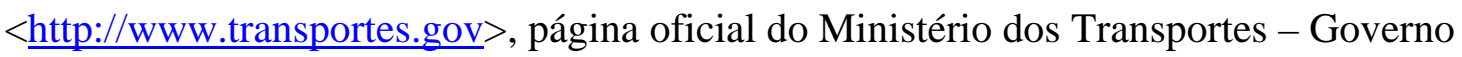
Federal.

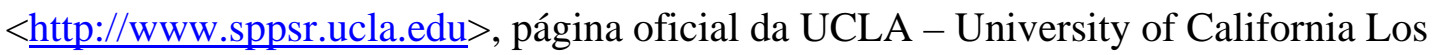
Angeles. 